\title{
AN INTERIM REPORT ON FLOWS IN THE LOWER ROANOKE RIVER, AND WATER QUALITY AND HYDRODYNAMICS OF ALBEMARLE SOUND, NORTH CAROLINA, OCTOBER 1989-APRIL 1991
}

By Jerad D. Bales, A.G. Strickland, and Ronald G. Garrett

\section{U.S. GEOLOGICAL SURVEY}

Open-File Report 92-123

Albemarle-Pamlico Estuarine Study Report 92-12

Prepared in cooperation with the

ALBEMARLE-PAMLICO ESTUARINE STUDY

DIVISION OF WATER RESOURCES of the

NORTH CAROLINA DEPARTMENT OF ENVIRONMENT, HEALTH, AND

NATURAL RESOURCES

U.S. ARMY CORPS OF ENGINEERS

Raleigh, North Carolina 
U.S. DEPARTMENT OF THE INTERIOR

MANUEL LUJAN, JR., Secretary

U.S. GEOLOGICAL SURVEY

Dallas L. Peck, Director

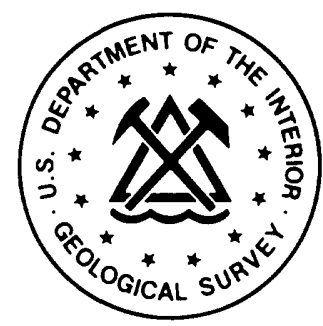

For additional information write to:

District Chief

U.S. Geological Survey 3916 Sunset Ridge Road

Raleigh, North Carolina 27607
Copies of this report can be purchased from:

U.S. Geological Survey

Books and Open-File Reports Section Federal Center, Box 25425

Denver, Colorado 80225 


\section{CONTENTS}

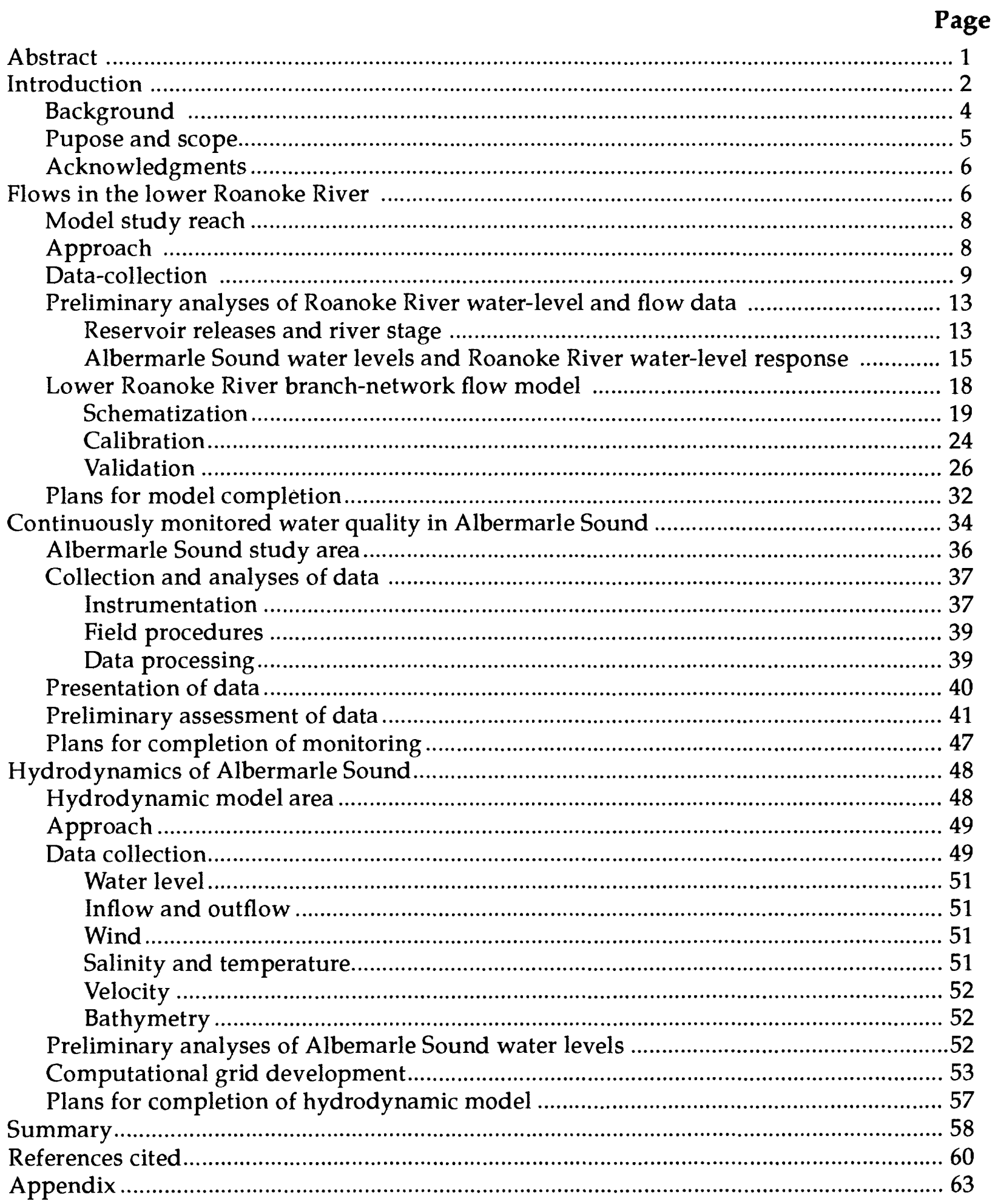




\section{ILLUSTRATIONS}

Page

Figure 1. Map showing Albemarle Sound drainage area

3

2. Map showing Roanoke River between the State Highway 11-42 bridge and Albemarle Sound, and data-collection network

3-6. Graph showing water-level fluctuations in the:

3. Lower Roanoke River at (A) Scotland Neck and Oak City, (B) Hamilton and Williamston, and (C) State Highway 45 bridge and Jamesville in response to large changes in discharge at Roanoke Rapids, November 28-December 5, 1990

4. Lower Roanoke River at (A) Scotland Neck and Oak City, (B) Hamilton and Williamston, and (C) Jamesville in response to rapid fluctuations in discharge at Roanoke Rapids, July 24-August 1, 1990 16

5. Roanoke River at Oak City, Hamilton, and Williamston, March 25April 3, 1988

6. Roanoke River at Jamesville and the State Highway 45 bridge, February 1-7, 1991 18

7. Example occurrences of downstream Roanoke River water level exceeding upstream water level, October 1-10, 1990 19

8. Idealized branch-network model schematization 20

9. Schematization of the lower Roanoke River between the State Highway 11-42 bridge and Jamesville

10-13. Graphs showing:

10. Observed and simulated water level at Hamilton for low and midrange (June 24-July 6, 1990) and high (March 13-16, 1990) water-level conditions for model calibration

11. Observed and simulated discharge at Hamilton, Oak City, River Mile 40.8, and Williamston for low and mid-range (June 24July 6, 1990) water-level conditions, and at Oak City and Williamston for high (March 13-16, 1990) water-level conditions for model calibration

12. Observed and simulated water level at Hamilton for low (July 28August 1, 1990), mid-range (May 3-6, 1990), and high (March 14-22, 1991) water-level conditions for model validation 


\section{ILLUSTRATIONS, Continued--}

Page

13. Observed and simulated discharge at Oak City, Hamilton, and Williamston for mid-range (May 3-6, 1990) water-Ievel conditions, and at Oak City and Williamston for high (March 14-22, 1991) water-level conditions for model validation

14. Data-collection sites and model schematization for the Roanoke River between Williamston and Albemarle Sound

15. Graphs showing observed and model-simulated water leveIs at Hamilton and at Williamston 33

16. Map showing Albemarle Sound data-collection network 37

17-20. Boxplots showing:

17. Salinity, near surface and near bottom, at sites 1-5 for early spring conditions, March 1-5, 1991

18. Salinity, near surface and near bottom, at sites 1,3 , and 5 for late summer conditions, August 6-10, 1990 43

19. Dissolved-oxygen concentrations, near surface and near bottom, at sites 1-4 for early spring conditions, March 1-5, 1991

20. Dissolved-oxygen concentrations, near surface and near bottom, at sites 1, 3, and 5 for late summer conditions, August 6-10, 1990

21. Graphs showing continuous records of near-surface temperature and dissolved-oxygen concentration at mid-depth; site 3, April 1990

22. Graphs showing water levels in Croatan Sound and the Roanoke River at State Highway 45 and U.S. Highway 64 bridges for October 6-9, 1990, and February 1-7, 1991

23. Map showing western Albemarle Sound computational grid of landsurface elevations 


\section{TABLES}

Page

Table 1.Drainage areas and river miles at selected locations .

2.Water-level data collection in the lower Roanoke River and

Cashie River.

3.Discharge measurements in the Roanoke River downstream from river mile 67.0

4.Summary of branches and cross sections used in the flow model for the Roanoke River between the State Highway 11-42 bridge and Jamesville.

5.Measured flows and flows computed using branch-network model for Roanoke River study-reach model calibration and validation

6.Continuous water-quality monitoring locations in and near Albemarle Sound.

7.Maximum and minimum values for salinity, temperature, and dissolvedoxygen concentrations at water-quality monitoring sites 1-5 in Albemarle Sound, 1989-91

8.Number of days with maximum water temperature exceeding $25^{\circ} \mathrm{C}$ or minimum dissolved-oxygen concentration less than 5 milligrams per liter at sites 1,3, and 5, April to September 1990

9.Water-level and wind data-collection network for Albemarle Sound hydrodynamic modeling 


\title{
AN INTERIM REPORT ON FLOWS IN THE LOWER ROANOKE RIVER, AND
}

\author{
WATER QUALITY AND HYDRODYNAMICS OF ALBEMARLE SOUND,
}

\author{
NORTH CAROLINA, OCTOBER 1989-APRIL 1991
}

\author{
By Jerad D. Bales, A.G. Strickland, and Ronald G. Garrett
}

\begin{abstract}
A 3-year investigation was begun in 1990 to (1) develop a model for computing flows in the lower 67 miles of the Roanoke River, (2) characterize water-quality conditions in Albemarle Sound, and (3) describe the circulation regime of Albemarle Sound. This report summarizes data and results obtained during the first year of the study.

Water levels in Albemarle Sound may affect flows in the Roanoke River as far upstream as Hamilton, North Carolina, 59 miles upstream from the sound. Water levels in the lower 20 miles of the Roanoke fluctuate in response to water levels in Albemarle Sound even during periods of high inflow. Moreover, the presence of higher water levels downstream relative to those upstream indicates that reverse flows likely occurred in the Roanoke River downstream from Jamesville in October and December 1990.

A one-dimensional, unsteady flow model has been implemented to compute flows in the Roanoke River between the State Highway 11-42 bridge and Jamesville. The model presently (1991) is calibrated and validated for the reach of the Roanoke between the State Highway 11-42 bridge and Williamston. For the calibrated model, simulated and observed water levels at Hamilton typically differed by less than 0.5 foot. The difference between observed and simulated depth of flow was less than 5 percent at high water levels. Based on a comparison of simulated flows with 33 discharge measurements, simulated flows generally were within 10 percent of observed values. Actual flow measurements, which are used to develop stage-discharge ratings, are considered to have an accuracy of no better than 5 percent. Hence, these flow simulations have nearly the accuracy of discharges computed from stage-discharge relations in other streams.

Near-surface and near-bottom specific conductance, near-surface water temperature, and near-surface, mid-depth, and near-bottom dissolved-oxygen concentrations are monitored at 15-minute intervals at 10 locations in Albemarle Sound. Salinity values calculated from observed specific conductance ranged from essentially 0 to more than 9 parts per thousand, and the observed daily range (difference between daily maximum and minimum values) of salinity at each site generally was less than 1 part per thousand. The observed annual variation in water temperature was more than 30 degrees Celsius; diurnal temperature fluctuations were about 1.3 degrees Celsius. Dissolved-oxygen concentrations ranged from supersaturated to hypoxic conditions. The daily range in dissolved oxygen typically was larger during the summer months than during the rest of the year.
\end{abstract}


Tides at the mouth of the Roanoke River are well correlated with tides in Croatan Sound. Even during periods of falling water levels in Albemarle Sound, the tidal signal at Croatan Sound is transmitted upstream to the mouth of the Roanoke River. There is about a 9-hour lag between the time of high tide in Croatan Sound and high tide at the mouth of the Roanoke River, but the observed tidal amplitude in Croatan Sound and at the mouth of the Roanoke generally was about 0.45 foot.

\section{INTRODUCTION}

In 1990, a 3-year investigation was begun to (1) develop a model for computing flows in the lower Roanoke River between Williamston and Albemarle Sound, and evaluate flow distributions in the Roanoke River delta, (2) characterize water-quality conditions in Albemarle Sound, and (3) describe the circulation regime of Albemarle Sound, particularly in relation to inflows.

The Roanoke River is one of North Carolina's most important surface-water resources. The Roanoke River drainage basin includes $9,666 \mathrm{mi}^{2}$ in southern Virginia and northern North Carolina (fig. 1). The annual average discharge of the Roanoke to Albemarle Sound is estimated to be about $8,900 \mathrm{ft}^{3} / \mathrm{s}$ (Giese and others, 1985). Interest in the lower Roanoke River (between Roanoke Rapids and Albemarle Sound) has increased recently because of the creation of the Roanoke River National Wildlife Refuge, the decline of striped bass and herring fisheries in the river (Manooch and Rulifson, 1989), the potential for increased wastewater discharges to the river, and the possibility of the transfer of additional water out of the Roanoke basin.

The Roanoke River flows into Albemarle Sound (fig. 1) through a complex system of distributaries in the river delta. Albemarle Sound is an extensive, permanent oligohaline estuary that is unique on the East Coast (Copeland and others, 1983). The sound receives drainage from an $18,359-\mathrm{mi}^{2}$ basin, including the Roanoke River basin, and has a surface area of $480 \mathrm{mi}^{2}$. Seven lateral estuaries (Chowan, Perquimans, Pasquotank, Little, North, Alligator, and Scuppernong Rivers) and Currituck Sound contribute an additional $500 \mathrm{mi}^{2}$ of open water to the system. Albemarle Sound is an important nursery area for estuarinedependent fish and serves as a pathway for anadromous fish spawning in the freshwater tributaries of Albemarle Sound. Albemarle Sound contributes more than half of the total freshwater inflow to Pamlico Sound, which is connected to Albemarle Sound by Croatan and Roanoke Sounds.

Despite the importance of these resources, the Roanoke-Albemarle system has been identified as an area in which hydrologic and water-quality information is sorely deficient for characterization and management of the resource (Copeland, 1989). Because of severe water-quality problems in the 1970's, the Chowan River, the second largest tributary to Albemarle Sound, has been the subject of numerous hydrologic and water-quality studies. However, little information on flow and transport in the lower Roanoke River is available. Likewise, comprehensive studies have not previously been conducted on circulation and transport in Albemarle Sound, or on the relation between Albemarle Sound circulation and Roanoke River inflows. 


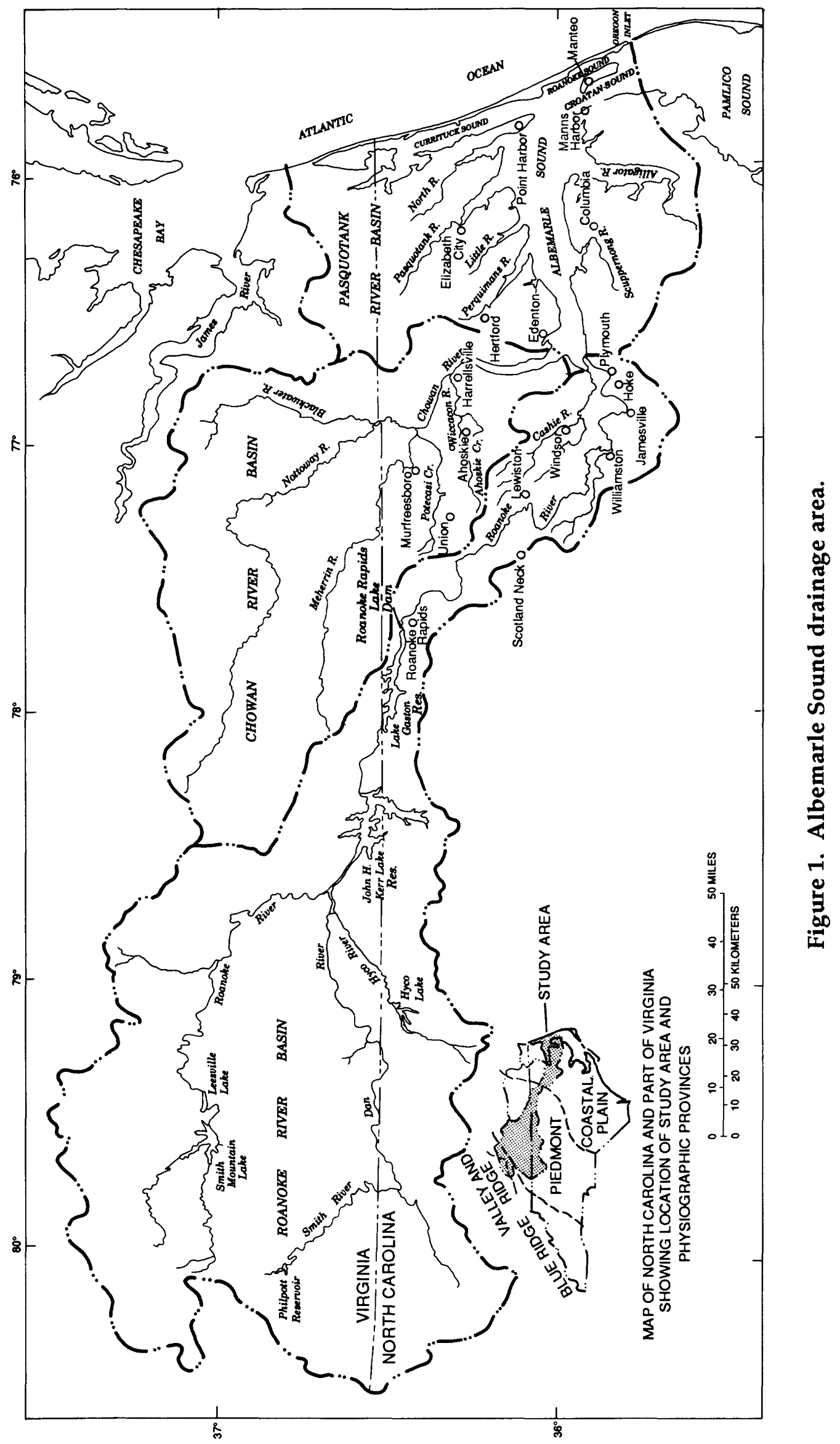


In 1990, the U.S. Geological Survey (USGS), in cooperation with the Albemarle-Pamlico Estuarine Study of the North Carolina Department of Environment, Health, and Natural Resources and the U.S. Army Corps of Engineers, began a 3-year investigation of flows in the Roanoke River and circulation in Albemarle Sound. The objectives of the investigation are to (1) develop a model for computing flow rates in the Roanoke River between Williamston and Albemarle Sound and evaluate flow distributions in the Roanoke River delta,

(2) characterize water-quality conditions in Albemarle Sound, and (3) describe the circulation regime of Albemarle Sound, particularly in relation to inflows. This investigation of flows in the Roanoke complements another ongoing USGS study conducted in cooperation with the North Carolina Division of Water Resources and designed to develop a flow model for the Roanoke River between the State Highway 11-42 bridge, near Oak City and Williamston.

\section{Background}

Human-induced perturbations to the natural flow regime of tidal rivers generally will result in some degree of change in downstream flow characteristics and estuarine circulation. More importantly, these changes can, and often do, have significant and unexpected effects on estuarine-dependent living resources.

Flows in the lower $137 \mathrm{mi}$ of the Roanoke River (from Roanoke Rapids to Albemarle Sound) have been controlled by a series of reservoirs since about 1952. (Flows in the Roanoke have been affected since the early 1900's by hydropower operations at Roanoke Rapids, although this regulation was much less extensive than it has been since 1952.) Historically, Roanoke River-Albemarle Sound was one of the most productive striped bass spawning areas on the East Coast, ranking third only to Chesapeake Bay and the Hudson River (U.S. Department of the Interior and U.S. Department of Commerce, 1987). However, annual striped bass landings decreased from about 15 to 20 million lbs during the mid-1960's and early 1970's to less than $300,000 \mathrm{lbs}$ during the late 1980 's, or a decline of more than 80 percent in 20 years (Manooch and Rulifson, 1989).

There is much uncertainty and debate about the causes for the decline of the RoanokeAlbemarle striped bass stocks, and it has not been demonstrated that changes in the flow regime are solely responsible for the observed declines. However, flow-related processes are undeniably critical at a number of key stages in the early life cycle of striped bass. Flow rates may govern the onset of spawning (Hassler and others, 1981). Transport and mixing processes (1) control the rate of egg transport downstream--eggs should remain suspended and within the channel, not in the flood plain; (2) determine the location at which the eggs hatch--hatching should occur in a region with an adequate food source and moderate flows; (3) affect larval feeding success and mortality--larvae should be transported to historical nursery grounds in the estuarine mixing zone; and (4) affect water quality. Transport and mixing processes also affect the supply of phytoplankton and zooplankton available to larval fish, and appear to be modifying the bathymetry, and thus circulation, in the historical nursery areas in the western part of Albemarle Sound.

In addition to fishery declines, resource managers face increasingly complex waterquality issues in the Roanoke River and Albemarle Sound. Because the Roanoke receives wastewater effluent from several large industrial facilities, including pulp and paper mills, the capacity of the river to assimilate wastes may soon be exceeded (Trevor Clements, North 
Carolina Division of Environmental Management, oral commun., 1991). Moreover, there are proposals to construct new industries, which would be major waste dischargers and users of water. Dioxin has been detected in the tissue of fish taken from the Roanoke, and health advisories have been posted, warning against eating fish taken from the area. Albemarle Sound also receives waste streams from the Chowan basin, which has a history of waterquality management problems, although waste loadings from the North Carolina part of the basin have been reduced in recent years. Accumulations of heavy metals have been detected in the sediments of Albemarle Sound.

Loss of habitat from declining water quality is also a concern. There is strong indication that mortality and poor reproductive success of some fish stocks are related to the loss of adequate summer estuarine habitat (Coutant, 1985). This loss of habitat occurs when temperatures are too high or when dissolved-oxygen concentrations are too low. The existence of these conditions has been documented for Albemarle Sound (Kornegay, 1988). Occurrence of hypoxia adversely affects other living resources and may be evidence of more pervasive water-quality problems.

Transport, mixing, and circulation processes need to be characterized in the complex Roanoke River delta and in Albemarle Sound. A better description of these processes is needed in order to (1) define flow conditions which are conducive to the survival, recovery, and future productivity of Roanoke River-Albemarle Sound fish stocks, and (2) provide the kinds of basic information needed for wasteload allocation and water-quality management.

\section{Purpose and Scope}

This report provides information collected during the initial phase of the investigation of flows in the lower Roanoke River and on the water quality and hydrodynamics of Albemarle Sound. Plans for completing the study are also described in this report. Because the originally proposed data collection has not been completed, conclusions in this report are considered to be preliminary pending the completion of the investigation.

Flows in the lower Roanoke River are investigated using data from a network of waterlevel recording stations and using a one-dimensional unsteady flow model. The model has been calibrated and validated for the reach of the Roanoke between the State Highway 11-42 bridge and Williamston. Results of the calibration and validation process are presented. The model has been extended downstream to Jamesville, but calibration is not complete; preliminary results are presented.

Water temperature, salinity, and dissolved-oxygen conditions in Albemarle Sound are characterized using data from water-quality monitors, which record information at 15minute intervals at 10 sites in the sound. Some water-level variations in Albemarle Sound and the computational grid for the Albemarle Sound hydrodynamic model also are presented.

Geographically, this report includes information from the lower $137 \mathrm{mi}$ of the Roanoke River (fig. 1), from Roanoke Rapids to the mouth, and all of Albemarle Sound. Most of the data presented in the report were collected between January 1990 and April 1991. Some data collected during earlier periods were used to calibrate, validate, and operate the Roanoke River flow model. 
This report is composed of three main sections. The first section deals with Roanoke River data and flow modeling; the second section concerns Albemarle Sound water-quality data recorded by a network of continuous monitors; and the third section focuses on Albemarle Sound hydrodynamic modeling. Within each section, the study area and approach are described, available data are presented and discussed, and the status of modeling efforts is given. Finally, an overview of future efforts to complete the investigation is discussed.

\section{Acknowledgments}

This report was prepared in cooperation with the Albemarle-Pamlico Estuarine Study and the Division of Water Resources of the North Carolina Department of Environment, Health, and Natural Resources; and the U.S. Army Corps of Engineers, Wilmington District. Contents of this report do not necessarily reflect the views and policies of any of the cooperators in this study.

Some of the information on Roanoke River channel geometry was supplied by the U.S. Army Corps of Engineers, Wilmington District; Weyerhaeuser Company; and R.A. Rulifson of East Carolina University. The Corps of Engineers and Virginia Electric and Power Company provided information on planned releases from Roanoke Rapids Lake, which facilitated scheduling of field activities. S. Tedder, J. Overton, D. Reid, and J. Sauber of the North Carolina Division of Environmental Management, and M. Street and J. Hawkins of the North Carolina Division of Marine Fisheries cooperated in the design of the water-quality data-collection network. The U.S. Coast Guard, Fifth District, granted permission for use of existing channel markers to support some of the data-collection instrumentation. The Coast Guard also helped to install instrumentation at some of the sites and to recover instrumentation at downed channel markers.

\section{FLOWS IN THE LOWER ROANOKE RIVER}

According to estimates by Giese and others (1985), conditions in Albemarle Sound affect flows in the Roanoke River as far upstream as Hamilton, which is about $59 \mathrm{mi}$ from the mouth of the river (fig. 2). Consequently, standard stream-gaging techniques, which are based on a unique and fairly stable relation between water level (or stage) and discharge at a selected site, cannot be used to obtain a continuous record of flow rates in the Roanoke River downstream from Hamilton.

Flow models may be used to obtain continuous records of discharge at sites where standard stream-gaging techniques are not applicable. A one-dimensional, unsteady flow model is being implemented for the Roanoke River from the State Highway 11-42 bridge (near Oak City) to the State Highway 45 bridge (near the mouth of the river). In this section of the report, the study area and the modeling approach are briefly described. The streamflow data-collection network is presented and data are discussed. Finally, preliminary modeling results are given, and plans for completion of the flow model are outlined. 


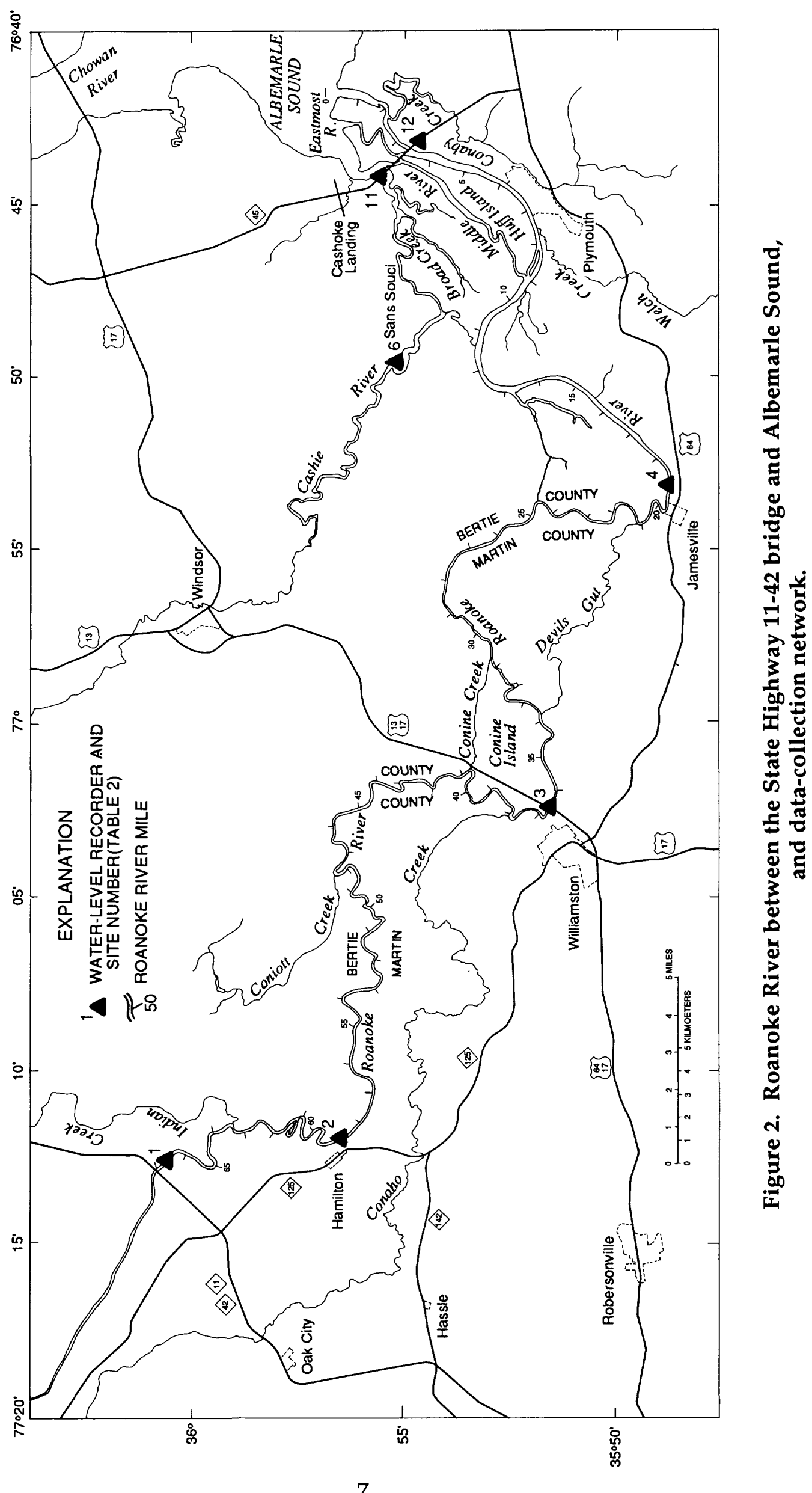




\section{Model Study Reach}

The study reach is a 137-mi section of the Roanoke River between Roanoke Rapids and Albemarle Sound (fig. 1) and includes the channels in the distributary at the mouth of the river, as well as a 6.7-mi reach of the Cashie River between Sans Souci and the State Highway 45 bridge (fig. 2). Drainage areas and river miles (measured upstream from Albemarle Sound) at key locations are given in table 1.

According to Manooch and Rulifson (1989), flows in the lower Roanoke were first affected by reservoir projects in August 1950 during construction of Kerr Lake, which was completed in 1952. Releases from Roanoke Rapids Lake, completed in 1955, are the principal factor controlling flows in the lower Roanoke River. Nevertheless, local inflows and conditions in Albemarle Sound affect flows in the lower Roanoke.

Table 1.--Drainage areas and river miles at selected locations $[--$, not applicable]

\begin{tabular}{|c|c|c|c|}
\hline $\begin{array}{c}\text { Location } \\
\text { (figs. } 1 \text { and 2) }\end{array}$ & $\begin{array}{c}\text { Site } \\
\text { number } \\
\text { (fig. } 2 \text { and } \\
\text { table 2) }\end{array}$ & $\begin{array}{l}\text { Drainage area } \\
\text { (square miles) }\end{array}$ & $\begin{array}{c}\text { Roanoke } \\
\text { River mile }\end{array}$ \\
\hline Roanoke River at Roanoke Rapids & -- & 8,384 & 137.0 \\
\hline Roanoke River at Scotland Neck & -- & 8,671 & 97 \\
\hline $\begin{array}{l}\text { Roanoke River at State Highway 11-42 bridge, } \\
\text { near Oak city }\end{array}$ & 1 & 8,813 & 67 \\
\hline Roanoke River at Hamilton & 2 & 8,886 & 59.2 \\
\hline Roanoke River at head of Conine Creek & -- & -- & 40.8 \\
\hline Mouth of Conoho Creek & -- & 120 & 38.1 \\
\hline Roanoke River at Williamston & 3 & 9,070 & 36.6 \\
\hline Roanoke River at Jamesville & 4 & 9,250 & 19.4 \\
\hline Roanoke River at State Highway 45 bridge & 12 & 9,665 & 3 \\
\hline Roanoke River at mouth & -- & 9,666 & 0 \\
\hline
\end{tabular}

According to Krug and others (1990) and Wilder and others (1978), the long-term average annual runoff in the vicinity of the study reach is about $14 \mathrm{in}$. , or $1.03 \mathrm{ft}^{3} / \mathrm{s} / \mathrm{mi}^{2}$. Consequently, the long-term average runoff at Oak City for the $429-\mathrm{mi}^{2}$ drainage area between Oak City and Roanoke Rapids is about $440 \mathrm{ft}^{3} / \mathrm{s}$. The average runoff at Williamston for the $257-\mathrm{mi}^{2}$ drainage area between Oak City and Williamston is about $265 \mathrm{ft}^{3} / \mathrm{s}$. The average runoff at the mouth of the Roanoke River for the $596-\mathrm{mi}^{2}$ drainage area between Williamston and the mouth is about $615 \mathrm{ft}^{3} / \mathrm{s}$.

\section{Approach}

A one-dimensional unsteady flow model (Schaffranek and others, 1981) is being implemented to compute flows in the Roanoke River between the State Highway 11-42 
bridge near Oak City (site 1, fig. 2) and the State Highway 45 bridge (sites 11 and 12, fig. 2) near the mouth of the river. The approach leading to the development and implementation of the flow model consists of three primary phases: (1) data collection for model implementation and operation; (2) model calibration, validation, and testing; and (3) model application.

Data required to properly calibrate, validate, and operate the model include: (1) continuous records of inflow rates or water-surface elevation at the upstream boundary of the study reach; (2) continuous records of water level at downstream boundaries; (3) crosssectional geometry (including the flood plain) throughout the study reach; (4) wind speed and direction; and (5) stage records and flow rates at selected locations throughout the study reach to calibrate and validate the model.

Model development consists of calibration, validation, and sensitivity testing. Model calibration is accomplished by adjusting model parameters until model results agree with observations of water levels and flows (Ditmars and others, 1987). The model is considered to be validated if model results agree with observations distinct from those used for model calibration without further adjustment of model parameters (Ditmars and others, 1987). A sensitivity analysis is an integral part of any comprehensive modeling effort. The sensitivity of model results to small changes in boundary conditions (water level, wind, local inflow), computational time interval, model geometry, resistance coefficient, and numerical parameters is being evaluated.

The model is being implemented in phases. A model for the reach between the State Highway 11-42 bridge (river mile 67.0) and Williamston (river mile 36.6) has been calibrated and validated. This model has been extended downstream to Jamesville (river mile 19.4), and preliminary results are available, although verification and testing of this part of the model is not yet complete. Upon completion, the model will include the reach from the State Highway 11-42 bridge to the State Highway 45 bridge (river mile 3).

\section{Data-Collection}

Data collection in the lower Roanoke River and Cashie River study reach consists of (1) continuous measurements of water level, (2) discrete measurements of discharge, and (3) measurements of channel geometry and flood-plain topography.

Pertinent information about the water-level recorders in the study reach is summarized in table 2, and recorder locations in the study reach are shown in figure 2. Upstream from the State Highway 11-42 bridge, the water level is recorded at Scotland Neck and at Roanoke Rapids. Discharge is computed using a stage-discharge relation for the Roanoke Rapids site. Data from these stations are also used in this report. All water levels are referenced to sea level.

Forty-seven discharge measurements were made in the study reach. Those measurements are summarized in table 3 . 
Table 2.--Water-level data collection in the lower Roanoke River and Cashie River

[USGS, U.S. Geological Survey; --, not applicable]

\begin{tabular}{cccccc}
\hline $\begin{array}{c}\text { Site } \\
\text { number } \\
\text { fig. 2) }\end{array}$ & $\begin{array}{c}\text { USGS } \\
\text { station } \\
\text { number }\end{array}$ & \multicolumn{1}{c}{ Location } & Latitude & Longitude & $\begin{array}{c}\text { Recording } \\
\text { interval } \\
\text { (in minutes) }\end{array}$ \\
\hline-- & 02080500 & $\begin{array}{c}\text { Roanoke River at } \\
\text { Roanoke Rapids } \\
\text { Roanoke River near } \\
\text { Scotland Neck }\end{array}$ & $36^{\circ} 27^{\prime} 37^{\prime \prime}$ & $77^{\circ} 38^{\prime} 04^{\prime \prime}$ & 30 \\
-- & 02081000 & $36^{\circ} 34^{\prime \prime}$ & $77^{\circ} 23^{\prime} 03^{\prime \prime}$ & 60 \\
1 & 02081022 & $\begin{array}{c}\text { Roanoke River near } \\
\text { Oak City }\end{array}$ & $36^{\circ} 00^{\prime} 50^{\prime \prime}$ & $77^{\circ} 12^{\prime} 55^{\prime \prime}$ & 60 \\
2 & 02081028 & $\begin{array}{c}\text { Roanoke River at Hamilton } \\
3\end{array}$ & $35^{\circ} 56^{\prime} 50^{\prime \prime}$ & $77^{\circ} 12^{\prime} 10^{\prime \prime}$ & 60 \\
4 & 0208109400 & $\begin{array}{c}\text { Roanoke River at } \\
\text { Williamston }\end{array}$ & $35^{\circ} 51^{\prime} 40^{\prime \prime}$ & $77^{\circ} 02^{\prime} 20^{\prime \prime}$ & 60 \\
12 & 0208114150 & $\begin{array}{c}\text { Roanoke River at State } \\
\text { Highway 45 bridge }\end{array}$ & $35^{\circ} 54^{\prime} 53^{\prime \prime}$ & $76^{\circ} 43^{\prime} 23^{\prime \prime}$ & 15 \\
6 & 0208113400 & $\begin{array}{c}\text { Cashle River at Sans Souci } \\
\text { Ferry }\end{array}$ & $35^{\circ} 54^{\prime} 42^{\prime \prime}$ & $76^{\circ} 49^{\prime} 04^{\prime \prime}$ & 15 \\
11 & 10208114360 & $\begin{array}{c}\text { Cashie River at State } \\
\text { Highway 45 bridge }\end{array}$ & $35^{\circ} 55^{\prime} 24^{\prime \prime}$ & $76^{\circ} 44^{\prime} 01^{\prime \prime}$ & 15 \\
\hline
\end{tabular}

More than 100 channel cross sections are available for the study reach. Many of the cross sections were obtained from previous surveys made by the U.S. Army Corps of Engineers. Cross sections for the Roanoke River downstream from Plymouth, as well as for the channels in the distributary, were obtained from other sources, but the datum for these cross sections is unknown. More than 40 cross-sectional surveys were made by the USGS.

The hydrography and topography of the Roanoke River study reach have been integrated into a geographic information system (GIS). Digitized data were used to develop maps with contour lines at $1-\mathrm{ft}$ intervals up to an elevation of $15 \mathrm{ft}$. 
Table 3.--Discharge measurements in the Roanoke River downstream from river mile 67.0

$\left[\mathrm{ft}^{3} / \mathrm{s}\right.$, cubic feet per second; $\mathrm{ft}$, feet; $\mathrm{ft}^{2}$, square feet; $\mathrm{rm}$, river mile; --, not applicable; Cr., Creek; R., River; nr, near; NC45, State Highway 45]

\begin{tabular}{|c|c|c|c|c|c|c|c|}
\hline $\begin{array}{c}\text { Site } \\
\text { number }\end{array}$ & $\begin{array}{l}\text { Location } \\
\text { (fig. 2) }\end{array}$ & Date & Time & $\begin{array}{l}\text { Flow } \\
\left(\mathrm{ft}^{3} / \mathrm{s}\right)\end{array}$ & $\begin{array}{l}\text { Water- } \\
\text { surface } \\
\text { elevation } \\
\quad(\mathrm{ft})\end{array}$ & $\begin{array}{l}\text { Channel } \\
\text { width } \\
\text { (ft) }\end{array}$ & $\begin{array}{c}\text { Channe } \\
\text { area } \\
\left(\mathrm{ft}^{2}\right)\end{array}$ \\
\hline \multirow[t]{10}{*}{1} & Roanoke rm 67.0 & $5-15-87$ & $1125-1230$ & 2,620 & 4.22 & 261 & 3,620 \\
\hline & Roanoke rm 67.0 & $12-16-87$ & $1430-1535$ & 10,780 & 14.06 & 320 & 6,675 \\
\hline & Roanoke rm 67.0 & $3-12-90$ & $1600-1800$ & 8,130 & 15.36 & 314 & 6,410 \\
\hline & Roanoke rm 67.0 & $3-13-90$ & $1125-1240$ & 6,400 & 13.54 & 310 & 5,870 \\
\hline & Roanoke rm 67.0 & $5-04-90$ & 0935-1055 & 8,520 & 12.10 & 305 & 5,300 \\
\hline & Roanoke rm 67.0 & $6-22-90$ & $1005-1130$ & 11,370 & 16.44 & 317 & 6,600 \\
\hline & Roanoke rm 67.0 & $6-26-90$ & $1655-1815$ & 5,590 & 9.03 & 288 & 4,320 \\
\hline & Roanoke rm 67.0 & $6-28-90$ & $1055-1300$ & 9,780 & 12.76 & 306 & 5,380 \\
\hline & Roanoke rm 67.0 & $6-29-90$ & $1255-1405$ & 8,100 & 12.26 & 303 & 5,230 \\
\hline & Roanoke rm 67.0 & $7-06-90$ & $1025-1205$ & 4,150 & 5.62 & 274 & 3,190 \\
\hline \multirow[t]{6}{*}{2} & Roanoke rm 59.2 & $3-12-90$ & $1315-1445$ & 10,270 & 14.33 & 325 & 6,410 \\
\hline & Roanoke rm 59.2 & $3-13-90$ & 0920-1035 & 8,170 & 12.74 & 320 & 5,885 \\
\hline & Roanoke rm 59.2 & $5-04-90$ & $1225-1345$ & 8,480 & 10.24 & 317 & 5,120 \\
\hline & Roanoke rm 59.2 & $6-27-90$ & $1230-1355$ & 7,820 & 9.31 & 311 & 4,820 \\
\hline & Roanoke rm 59.2 & $6-29-90$ & $1050-1145$ & 8,780 & 10.70 & 315 & 5,250 \\
\hline & Roanoke rm 59.2 & $7-06-90$ & $1400-1530$ & 4,140 & 4.32 & 291 & 3,310 \\
\hline \multirow[t]{2}{*}{-} & Roanoke rm 41 & $6-26-90$ & $1120-1305$ & 5,280 & $\left({ }^{a}\right)$ & 272 & 4,380 \\
\hline & Roanoke rm 41 & $7-05-90$ & $1420-1555$ & 2,010 & (a) & 263 & 3,330 \\
\hline \multirow[t]{2}{*}{--} & Head of Conine $\mathrm{Cr}$. & $6-26-90$ & 0915-1035 & 219 & $(\mathrm{a})$ & 54 & 408 \\
\hline & Head of Conine Cr. & $3-20-91$ & 0915-1000 & 604 & (a) & 60 & 498 \\
\hline-- & Conoho Cr. at mouth & $3-20-91$ & $1110-1215$ & 525 & $\left({ }^{a}\right)$ & 66 & 540 \\
\hline \multirow[t]{7}{*}{3} & Roanoke rm 36.6 & $3-14-90$ & $0845-1020$ & 10,710 & 6.95 & 271 & 5,390 \\
\hline & Roanoke rm 36.6 & $3-16-90$ & 0915-1125 & 9,000 & 5.76 & 268 & 5,110 \\
\hline & Roanoke rm 36.6 & $5-04-90$ & $1515-1615$ & 8,730 & 5.15 & 269 & 4,940 \\
\hline & Roanoke rm 36.6 & $6-26-90$ & 0855-1020 & 6,510 & 4.62 & 265 & 4,800 \\
\hline & Roanoke rm 36.6 & $6-26-90$ & $1100-1210$ & 6,550 & 4.56 & 265 & 4,810 \\
\hline & Roanoke rm 36.6 & $6-26-90$ & $1455-1600$ & 6,800 & 4.56 & 265 & 4,790 \\
\hline & Roanoke rm 36.6 & $6-27-90$ & 0800-0950 & 7,230 & 4.70 & 266 & 4,760 \\
\hline
\end{tabular}

Footnotes are located at end of table. 
Table 3.--Discharge measurements in the Roanoke River downstream from river mile 67.0--Continued

\begin{tabular}{|c|c|c|c|c|c|c|c|}
\hline $\begin{array}{c}\text { Site } \\
\text { number }\end{array}$ & $\begin{array}{l}\text { Location } \\
\text { (fig. } 2 \text { ) }\end{array}$ & Date & Time & $\begin{array}{l}\text { Flow } \\
\left(\mathrm{ft}^{3} / \mathrm{s}\right)\end{array}$ & $\begin{array}{l}\text { Water- } \\
\text { surface } \\
\text { elevation } \\
\text { (ft) }\end{array}$ & $\begin{array}{l}\text { Channel } \\
\text { width } \\
\text { (ft) }\end{array}$ & $\begin{array}{c}\text { Channel } \\
\text { area } \\
\left(\mathrm{ft}^{2}\right)\end{array}$ \\
\hline & Roanoke rm 36.6 & $6-29-90$ & 0820-0925 & 8,990 & 5.32 & 268 & 4,980 \\
\hline & Roanoke rm 36.6 & $7-05-90$ & $1655-1810$ & 2,180 & 1.47 & 257 & 3,960 \\
\hline & Roanoke rm 36.6 & $8-01-90$ & $0955-1100$ & 3,850 & 2.18 & 262 & 4,260 \\
\hline & Roanoke rm 36.6 & $3-20-91$ & $1310-1425$ & 10,750 & 6.55 & 272 & 5,390 \\
\hline & Roanoke rm 36.6 & $3-21-91$ & $1330-1500$ & 11,970 & 6.86 & 275 & 5,400 \\
\hline \multirow[t]{2}{*}{--} & Head of Conine $\mathrm{Cr}$. & $6-26-90$ & 0915-1035 & 219 & (a) & 54 & 408 \\
\hline & Head of Conine $\mathrm{Cr}$. & $3-20-91$ & $0915-1000$ & 604 & (a) & 60 & 498 \\
\hline-- & Conoho Cr. at mouth & $3-20-91$ & $1110-1215$ & 525 & (a) & 66 & 540 \\
\hline \multirow[t]{12}{*}{3} & Roanoke rm 36.6 & $3-14-90$ & $0845-1020$ & 10,710 & 6.95 & 271 & 5,390 \\
\hline & Roanoke rm 36.6 & $3-16-90$ & $0915-1125$ & 9,000 & 5.76 & 268 & 5,110 \\
\hline & Roanoke rm 36.6 & $5-04-90$ & $1515-1615$ & 8,730 & 5.15 & 269 & 4,940 \\
\hline & Roanoke rm 36.6 & $6-26-90$ & $0855-1020$ & 6,510 & 4.62 & 265 & 4,800 \\
\hline & Roanoke rm $36 . .6$ & $6-26-90$ & $1100-1210$ & 6,550 & 4.56 & 265 & 4,810 \\
\hline & Roanoke rm 36.6 & $6-26-90$ & $1455-1600$ & 6,800 & 4.56 & 265 & 4,790 \\
\hline & Roanoke rm 36.6 & $6-27-90$ & 0800-0950 & 7,230 & 4.70 & 266 & 4,760 \\
\hline & Roanoke rm 36.6 & $6-29-90$ & $0820-0925$ & 8,990 & 5.32 & 268 & 4,980 \\
\hline & Roanoke rm 36.6 & $7-05-90$ & $1655-1810$ & 2,180 & 1.47 & 257 & 3,960 \\
\hline & Roanoke rm 36.6 & $8-01-90$ & $0955-1100$ & 3,850 & 2.18 & 262 & 4,260 \\
\hline & Roanoke rm 36.6 & $3-20-91$ & $1310-1425$ & 10,750 & 6.55 & 272 & 5,390 \\
\hline & Roanoke rm 36.6 & $3-21-91$ & $1330-1500$ & 11,970 & 6.86 & 275 & 5,400 \\
\hline \multirow[t]{3}{*}{4} & Roanoke rm 19.4 & $8-01-90$ & $1240-1415$ & 4,320 & 1.03 & 404 & 5,700 \\
\hline & Roanoke rm 19.4 & $1-10-91$ & $0930-1115$ & 11,470 & 1.66 & 414 & 6,000 \\
\hline & Roanoke rm 19.4 & $3-22-91$ & 0915-1055 & 10,530 & 2.26 & 412 & 6,200 \\
\hline \multirow[t]{3}{*}{--} & Roanoke rm 7.0 & $8-23-90$ & 0953-1135 & 2,060 & $\mathrm{~b}_{12.39}$ & 440 & 7,580 \\
\hline & Roanoke rm 7.0 & $8-24-90$ & $0855-1040$ & 2,550 & $\mathrm{~b}_{12.57}$ & 440 & 7,590 \\
\hline & Roanoke rm 7.0 & $8-27-90$ & 0840-1017 & 1,290 & $\mathrm{~b}_{12.40}$ & 440 & 7,310 \\
\hline \multirow[t]{3}{*}{--} & Middle R. nr Plymouth & $8-23-90$ & $1240-1335$ & 940 & $\left({ }^{a}\right)$ & 275 & 3,380 \\
\hline & Middle R. nr Plymouth & $8-24-90$ & $1110-1220$ & 1,910 & $\left(a^{a}\right)$ & 280 & 3,520 \\
\hline & Middle R. nr Plymouth & $8-27-90$ & $1040-1218$ & 520 & $\left({ }^{a}\right)$ & 280 & 3,350 \\
\hline
\end{tabular}

Footnotes are located at end of table. 
Table 3.--Discharge measurements in the Roanoke River downstream from river mile 67.0--Continued

\begin{tabular}{|c|c|c|c|c|c|c|c|}
\hline $\begin{array}{c}\text { Site } \\
\text { number }\end{array}$ & $\begin{array}{l}\text { Location } \\
\text { (fig. 2) }\end{array}$ & Date & Time & $\begin{array}{l}\text { Flow } \\
\left(\mathrm{ft}^{3} / \mathrm{s}\right)\end{array}$ & $\begin{array}{l}\text { Water- } \\
\text { surface } \\
\text { elevation } \\
\text { (ft) }\end{array}$ & $\begin{array}{l}\text { Channel } \\
\text { width } \\
\text { (ft) }\end{array}$ & $\begin{array}{c}\text { Channel } \\
\text { area } \\
\left(\mathrm{ft}^{2}\right)\end{array}$ \\
\hline-- & Middle R. nr NC45 & $8-24-90$ & $0000-1110$ & 2,410 & $b_{1} 11.64$ & 405 & 2,900 \\
\hline \multirow[t]{2}{*}{12} & Roanoke R. nr NC45 & $8-23-90$ & $1045-1405$ & 2,970 & $b_{11.38}$ & 515 & 6,710 \\
\hline & Roanoke R. nr NC45 & $8-24-90$ & $1200-1315$ & 4,330 & $b_{11.51}$ & 500 & 6,750 \\
\hline \multirow[t]{2}{*}{-- } & Eastmost R. nr NC45 & $8-23-90$ & $1445-1600$ & 780 & $b_{11.60}$ & 262 & 2,700 \\
\hline & Eastmost R. nr NC45 & $8-24-90$ & $1400-1440$ & 1,500 & $b_{1} 1.46$ & 265 & 2,900 \\
\hline
\end{tabular}

${ }^{a}$ Gaging station not located at these sites; no water level is available.

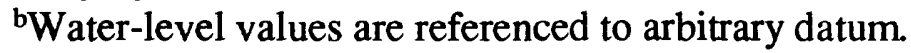

\section{Preliminary Analyses of Roanoke River Water-Level and Flow Data}

Completion of the flow model for the reach between the State Highway 11-42 bridge and the State Highway 45 bridge will allow the flows in the modeled reach to be quantified and characterized for a variety of inflow and downstream boundary conditions. Nevertheless, some insight can be gained into important hydrologic features of the lower Roanoke by using presently available data.

\section{Reservoir Releases and River Stage}

The movement through the lower Roanoke River of a wave resulting from a reservoir release at Roanoke Rapids Lake is depicted in figure 3. A fairly steady flow of about 14,800 $\mathrm{ft}^{3} / \mathrm{s}$ was maintained at Roanoke Rapids on November 30, 1990 (fig. 3A). Flows began decreasing sharply from $14,800 \mathrm{ft}^{3} / \mathrm{s}$ at 0100 hours on December 1,1990 , and reached a fairly steady value of about $1,000 \mathrm{ft}^{3} / \mathrm{s} 5$ hours later.

Continuous flow data were not available for the Roanoke River downstream from Roanoke Rapids at the time of this writing, but the water-level data can be used to characterize movement of the wave. A peak water-level value was reached at Scotland Neck at 0400 hours on December 1 (fig. 3A). The peak occurred 10 hours later at 1400 hours near Oak City (fig. 3A), and 16 hours later at 2000 hours at Williamston (fig. 3B). The effects of the Roanoke Rapids Lake reservoir release of November 30 on water level at Jamesville and at the State Highway 45 bridge were not detectable (fig. 3C).

At 1830 hours on December 4, 1990, flow at Roanoke Rapids began increasing quickly from $1,040 \mathrm{ft}^{3} / \mathrm{s}$ (fig. 3). The resulting rise in water level was first observed at 0200 hours on 


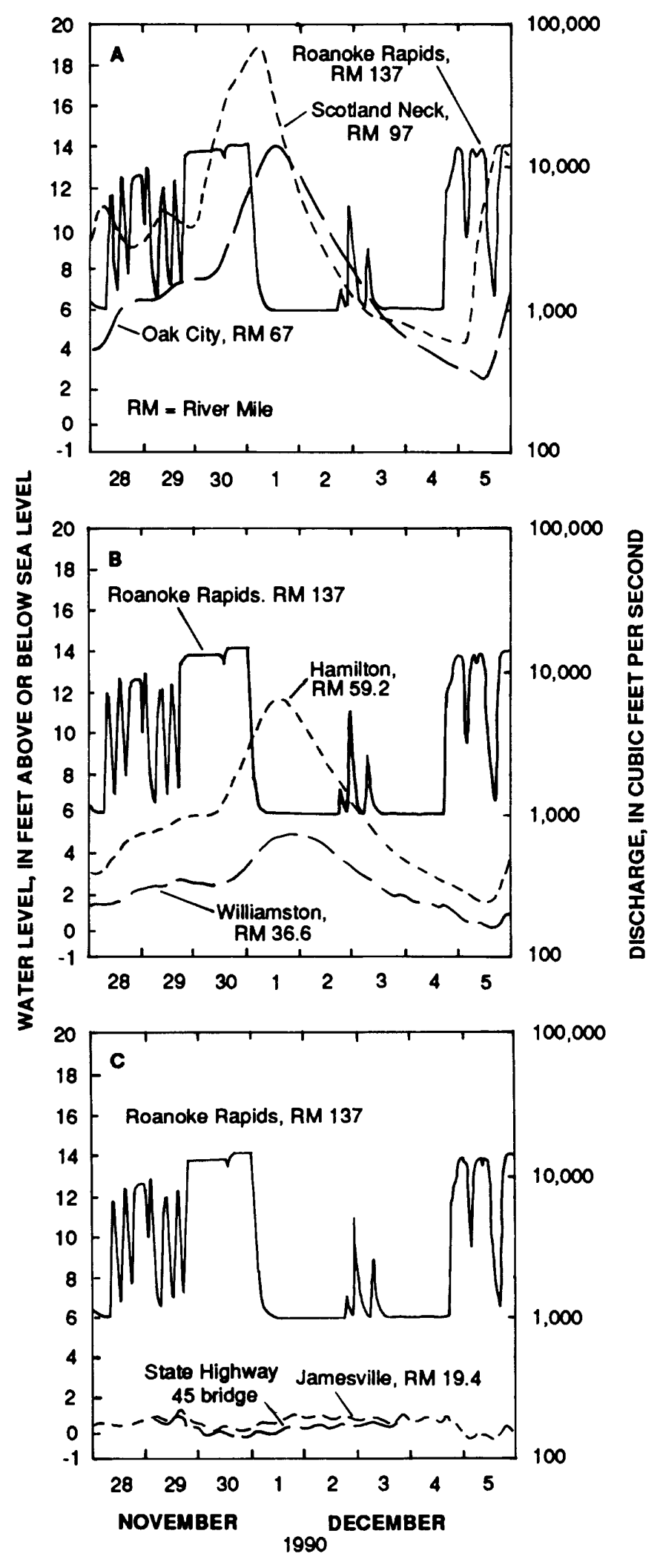

Figure 3. Water-level fluctuations in the lower Roanoke River at (A) Scotland Neck and Oak City, (B) Hamilton and Williamston, and (C) State Highway 45 bridge and Jamesville in response to large changes in discharge at Roanoke Rapids, November 28-December 5, 1990. 
December 5 at Scotland Neck (fig. 3A); at 1200 hours near Oak City (fig. 3A); and at 1600 hours at Williamston (fig. 3B).

The effect of peaking operations at Roanoke Rapids Dam on water levels in the lower Roanoke River is shown in figure 4 for the period July 24 to August 1, 1990. With the exception of the sustained releases on July 25 and 26 , water levels downstream from Hamilton apparently did not respond to peaking operations during this period (figs. $4 \mathrm{~B}$ and 4C). Moreover, the water level at Williamston (fig. 4B) on August 1 (at about 0300 hours) apparently did respond to Albemarle Sound water-level changes (as indicated by water-level rise at Jamesville at about midnight on August 1), which were transmitted up the river. In contrast to the July 1990 peaking operations, the short-term releases on December 2-3, 1990 (fig. 3A), had only a slight effect on water level at Scotland Neck.

Conditions during the periods shown in figures 3 and 4 represent only two of the many combinations of reservoir releases, river stage, local inflow, and Albemarle Sound water levels which may exist in the lower Roanoke River. However, two preliminary conclusions may be drawn from these data.

First, under some conditions, the Roanoke River water level at Williamston responds within about 12 hours to sustained changes in flows at Roanoke Rapids, which is about 100 mi upstream from Williamston. It should be noted, however, that water and water-borne substances travel downstream at a speed much lower than the speed at which water-level changes are transmitted. Second, short-term releases at Roanoke Rapids Dam, such as those that occur during peaking operations, do not have a detectable effect on water level downstream from about Hamilton under some conditions. Under other conditions, the effects of peaking operations on stage do not extend much farther downstream than Scotland Neck.

The effects of Albemarle Sound on water levels in the Roanoke River were observed as far upstream as Hamilton, although these effects may extend farther upstream. Consequently, changes in water level downstream from at least Hamilton do not always directly reflect a commensurate change in flow. For example, the flow at river mile 59.2 (Hamilton) on March 13, 1990, was $8,170 \mathrm{ft}^{3} / \mathrm{s}$ at a water surface elevation of $12.74 \mathrm{ft}$ (table $3)$. However, on June 29,1990 , the flow was higher $\left(8,780 \mathrm{ft}^{3} / \mathrm{s}\right)$ at a lower water surface elevation (10.70 ft) than on March 13. This demonstrates that the application of a flow model is necessary to evaluate changes in flow and transport in response to changes in upstream and downstream conditions.

\section{Albemarle Sound Water Levels and Roanoke River Water-Level Response}

As previously shown, changes in the water level in Albemarle Sound may affect water levels in the Roanoke River as far upstream as Hamilton. This effect can be seen in the hydrographs for Roanoke River at Oak City, Hamilton, and Williamston during March 25 to April 3, 1988, when the river water level apparently fluctuated at least partly in response to Albemarle Sound fluctuations (fig. 5). For about 10 days before and during this period, flows at Roanoke Rapids were steady at about $1,500 \mathrm{ft}^{3} / \mathrm{s}$. The response of Roanoke River water levels at Williamston and downstream at Jamesville to Albemarle Sound water-level fluctuations is shown in figure 3 for December 3-5, 1990, when the water level at Williamston was about $1.5 \mathrm{ft}$ higher than during the period shown in figure 5 . 


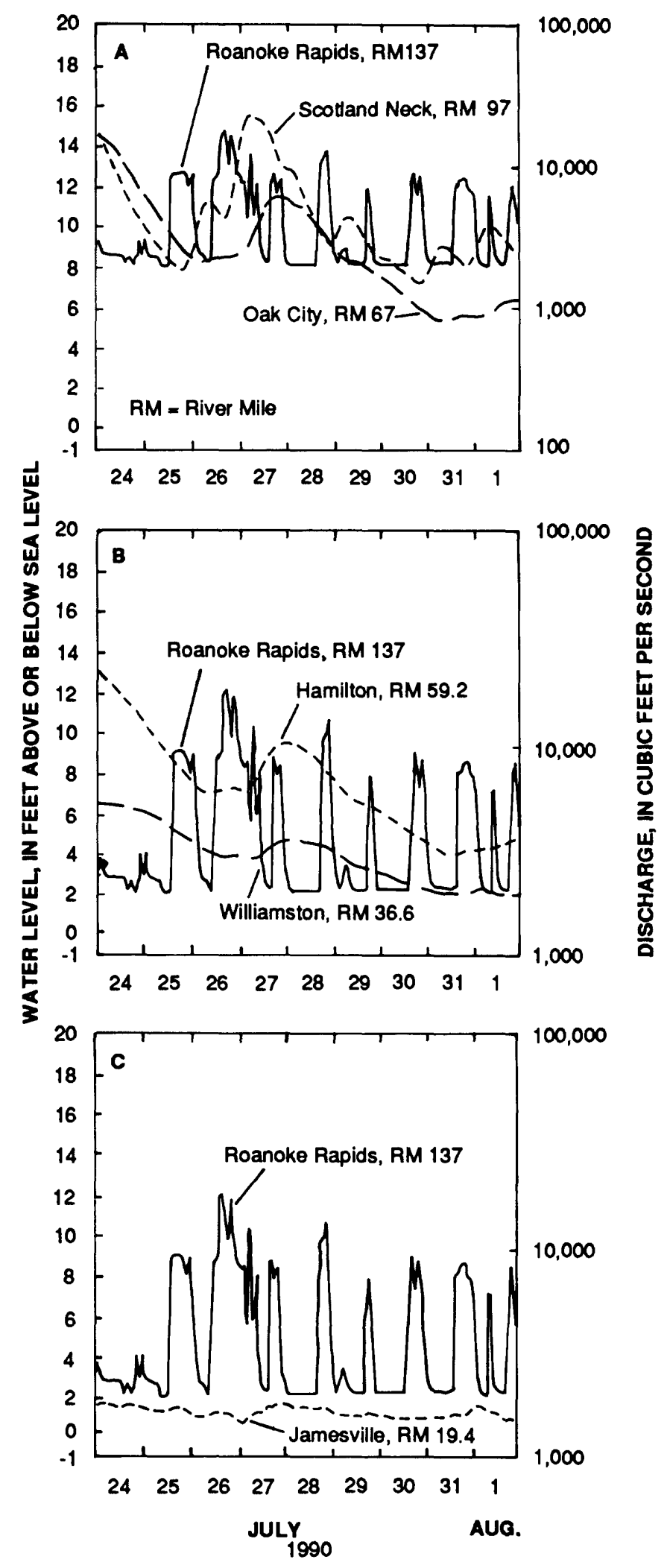

Figure 4. Water-level fluctuations in the lower Roanoke River at (A) Scotland Neck and Oak City, (B) Hamilton and Williamston, and (C) Jamesville in response to rapid fluctuations in discharge at Roanoke Rapids, July 24-August 1, 1990. 


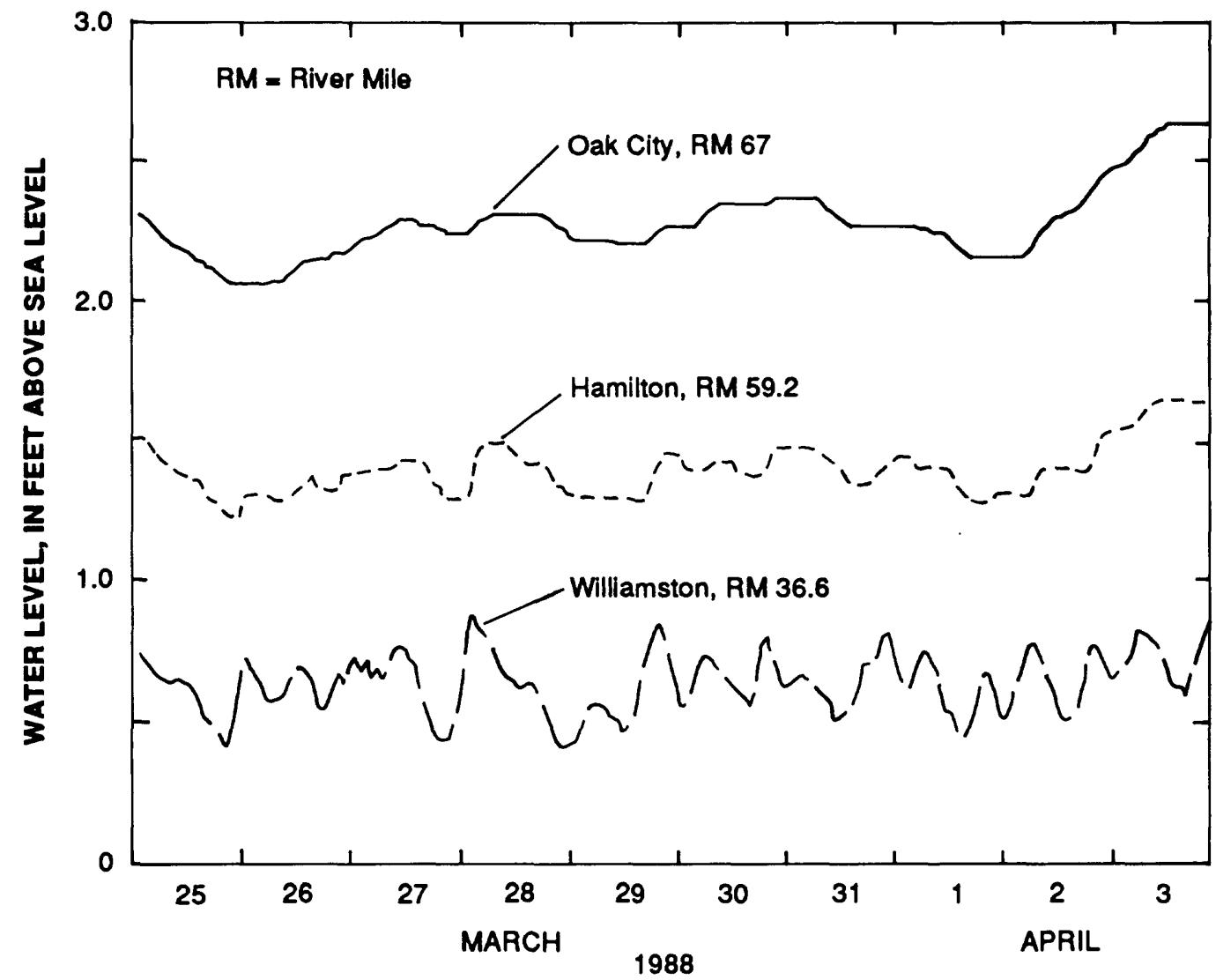

Figure 5. Water-level fluctuations in the Roanoke River at Oak City, Hamilton, and Williamston, March 25-April 3, 1988.

Water levels in the lower Roanoke River fluctuate in response to Albemarle Sound forcing even during periods of high flow. For example, flows at Roanoke Rapids were sustained at about 20,000 $\mathrm{ft}^{3} / \mathrm{s}$ from January 13 to February 3, 1991. Yet, semi-diurnal fluctuations in water level were recorded at the State Highway 45 bridge near the mouth of the river, and at the site $16 \mathrm{mi}$ upstream at Jamesville, during part of this period of high flow (fig 6).

From October 1, 1990, to May 21, 1991, the mean daily water-level range (difference between the daily maximum and the daily minimum stage) in the Roanoke River at the State Highway 45 bridge was $0.45 \mathrm{ft}$. The largest observed daily water-level range was $2.23 \mathrm{ft}$ on October 26, 1990, and the smallest range was $0.10 \mathrm{ft}$ on May 10,1991. The daily water-level range exceeded $0.60 \mathrm{ft} 22$ percent of the time. Also during this period, the mean water level was $0.92 \mathrm{ft}$ above sea level, with a maximum stage of $2.38 \mathrm{ft}$ on March 30, 1991, and a minimum stage of $-0.60 \mathrm{ft}$ on February 16, 1991.

Although the two sites located at the State Highway 45 bridge (Cashie River and Roanoke River) are only 4,800 ft apart, the water levels at the two sites apparently are seldom simultaneously equal. Between October 1990 and April 1991, the water levels measured simultaneously at the two sites were the same only 5 percent of the time. The water surface was higher at the Roanoke River site relative to the Cashie River site 55 percent of the time. Because the Cashie and Roanoke Rivers are hydraulically connected near the 
State Highway 45 bridge, cross-channel flows may be generated by this lateral water-surface gradient.

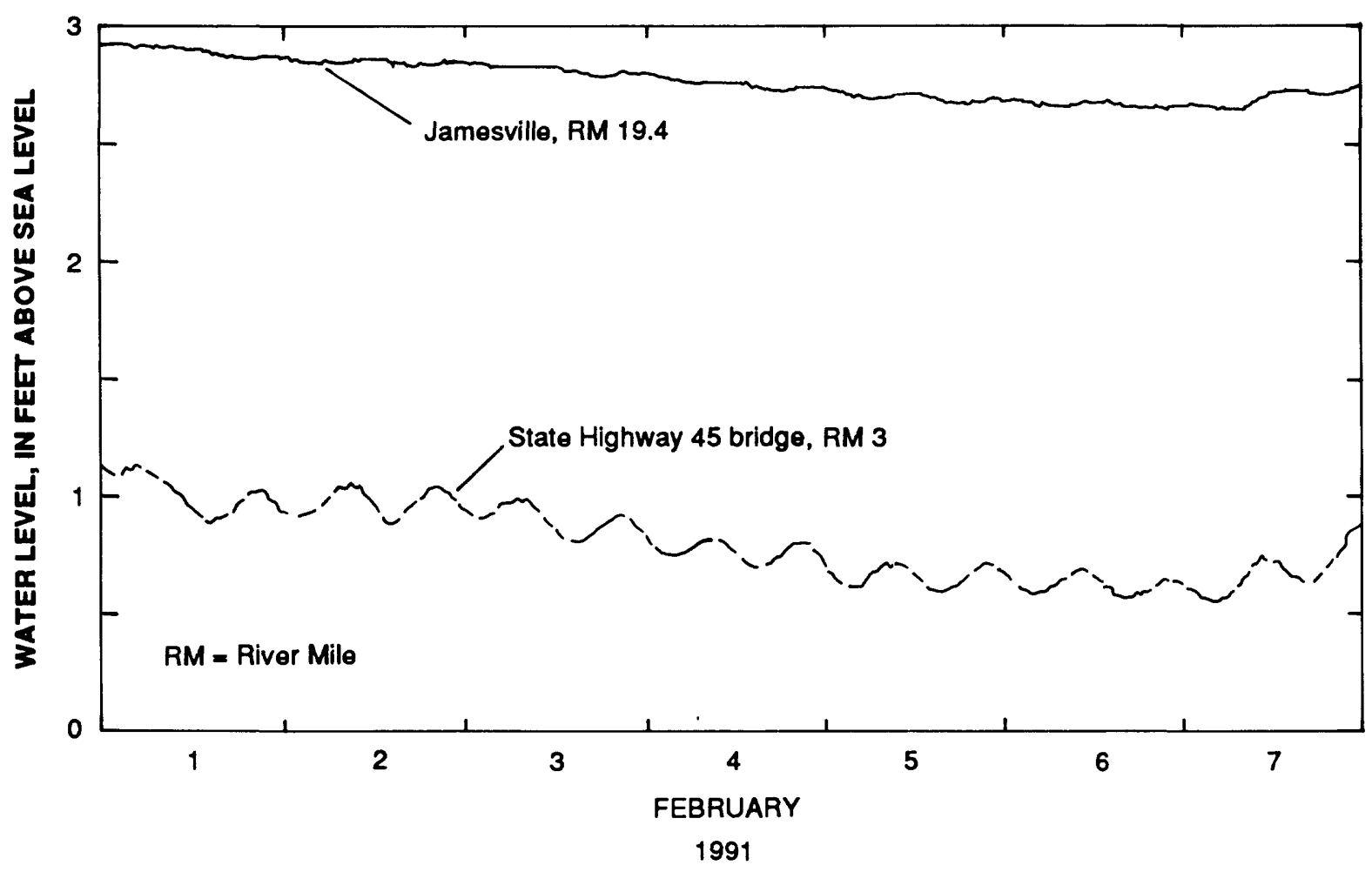

Figure 6. Water-level fluctuations in the Roanoke River at Jamesville and the State Highway 45 bridge, February 1-7, 1991.

The water surface also was observed to slope upstream on occasion. During October 1990, the Roanoke River water level at Jamesville was lower than that measured simultaneously at the State Highway 45 bridge 10 percent of the time. An example of this phenomenon is shown in figure 7. Water level was lower at Jamesville relative to that at the State Highway 45 bridge about 4 percent of the time during December 1990. During November 1990, and January through April 1991, water level at Jamesville was consistently higher than that measured simultaneously at the State Highway 45 bridge. The presence of higher water levels downstream relative to those upstream indicates that reverse flows likely occurred in the lower Roanoke River in October and December 1990. Completion of the unsteady flow model should allow the magnitude, timing, and geographic extent of these apparent reverse flows to be computed.

\section{Lower Roanoke River Branch-Network Flow Model}

The one-dimensional, unsteady flow model (Schaffranek and others, 1981) used in this study is capable of simulating overbank storage, flows in response to wind, and flows in a network of channels such as the Roanoke River distributary. The model has been applied to the Columbia River, Wash.; the tidally influenced lower Calcasieu River, La. (Arcement, 1988); and the Detroit River, Mich., which consists of a series of interconnected channels linking Lake Erie and Lake St. Clair (Schaffranek and others, 1981). 


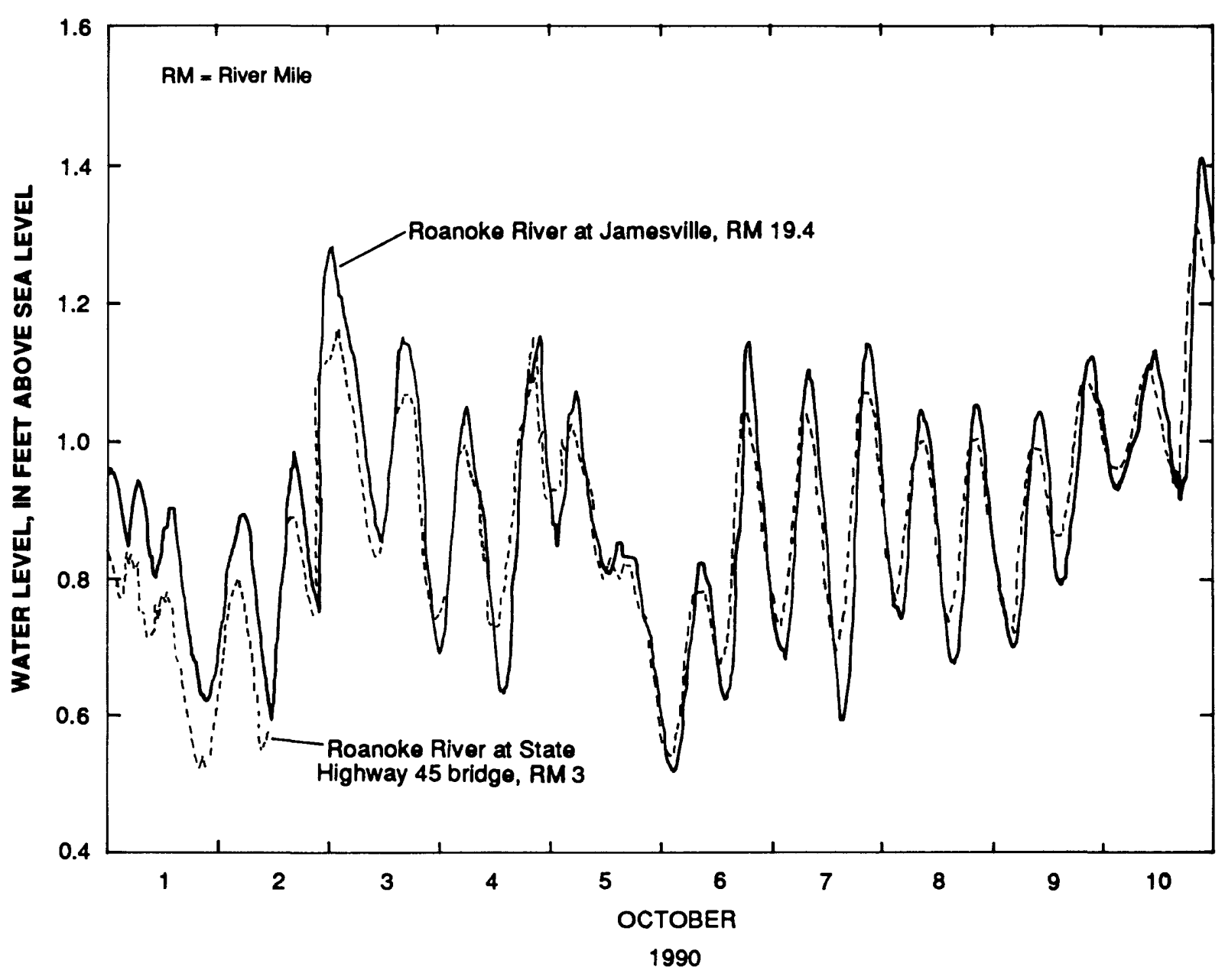

Figure 7. Example occurrences of downstream Roanoke River water level exceeding upstream water level, October 1-10, 1990.

The flow model is based on the cross-sectionally averaged (or one-dimensional), nonlinear momentum and continuity equations for unsteady flow in channels that are not eroding or aggrading. The governing equations include the assumptions that (1) the water density is essentially constant throughout the study reach, (2) the hydrostatic pressure distribution prevails, and (3) the channel slope is sufficiently mild that the flow remains subcritical. Because the governing equations are cross-sectionally averaged, the model cannot simulate bidirectional flow at a cross section. Bidirectional flow within the study reach, however, can be computed by the model. The governing equations are solved for the two unknowns--water level and flow--using a weighted, four-point, implicit finite-difference scheme. Development and use of the model requires information on channel geometry and synchronous, precisely timed data at the boundaries of the study reach.

\section{Schematization}

The reach to be modeled must be accurately described in order to implement the flow model. The model requires that the reach be described as a series of branches, segments, junctions, and cross sections or computational points (fig. 8). Locations at which two or more channels join or where local inflows must be accommodated are internal junctions. 
Locations at which a single branch is defined are external junctions. User-supplied boundary conditions (time series of water level or discharge) are required at external junctions. Channel reaches between junctions are called branches, which may be further subdivided into segments. Selection of segments is based on variability in cross-sectional geometry and computational considerations. Model results are provided at the endpoints of all segments.

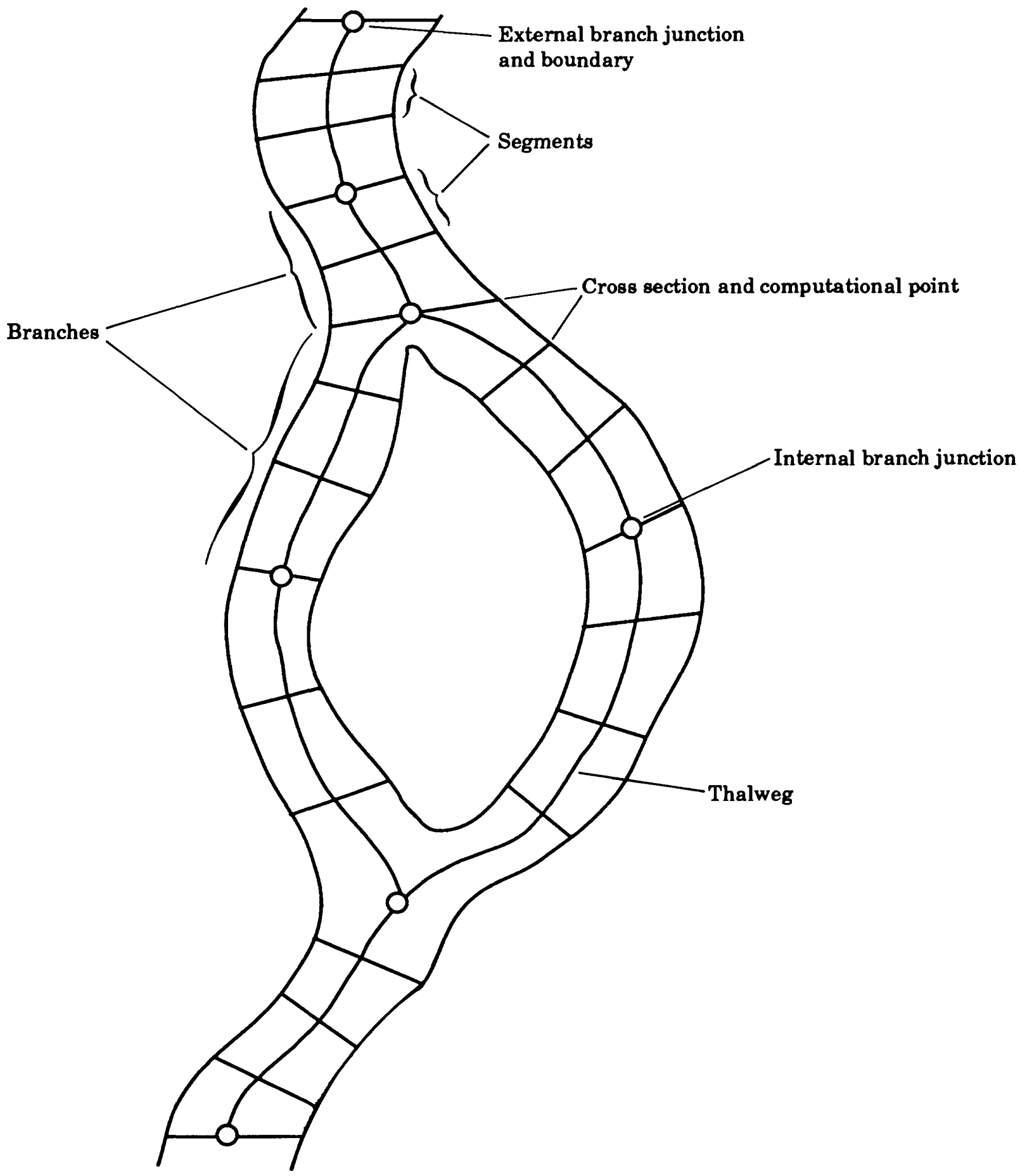

Figure 8. Idealized branch-network model schematization. 
Presently, the flow model has been constructed for the 48-mile reach of the Roanoke River between the State Highway 11-42 bridge near Oak City (site 1) and Jamesville (site 4). However, the model has been calibrated and validated only for the Oak City-to-Williamston (site 3) reach. The Oak City-to-Jamesville reach is represented by 16 branches (fig. 9) and 59 computation points or cross sections (table 4). Included in the model are Conoho Creek, Conine Creek, Devils Gut, and the mainstem of the Roanoke River.

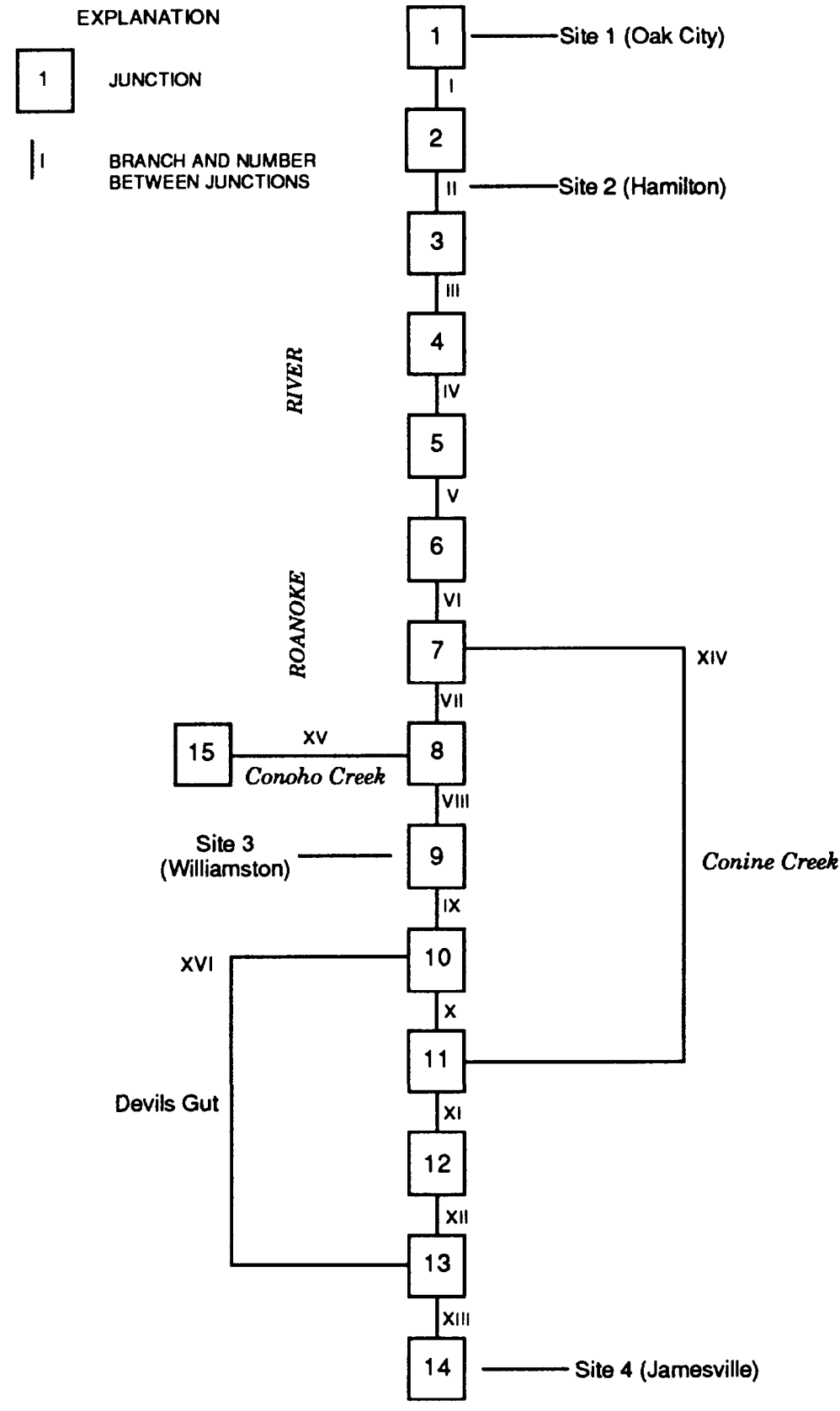

Figure 9. Schematization of the lower Roanoke River between the State Highway 11-42 bridge and Jamesville. 
Table 4.--Summary of branches and cross sections used in the flow model for the Roanoke River between the State Highway 11-42 bridge and Jamesville

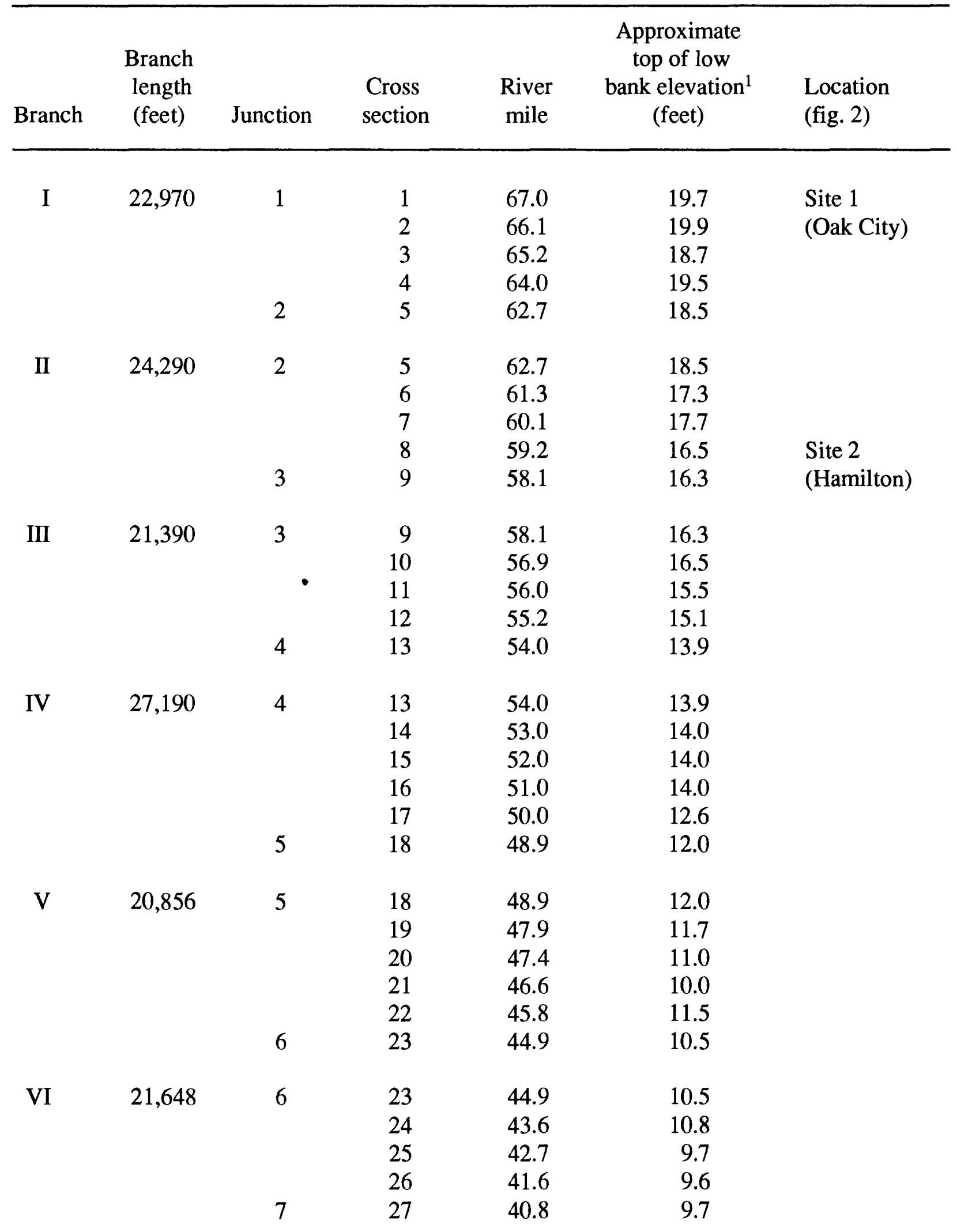


Table 4.--Summary of branches and cross sections used in the flow model for the Roanoke River between the State Highway 11-42 bridge and Jamesville--Continued

\begin{tabular}{|c|c|c|c|c|c|c|}
\hline Branch & $\begin{array}{l}\text { Branch } \\
\text { length } \\
\text { (feet) }\end{array}$ & Junction & $\begin{array}{l}\text { Cross } \\
\text { section }\end{array}$ & $\begin{array}{c}\text { River } \\
\text { mile }\end{array}$ & $\begin{array}{l}\text { Approximate } \\
\text { top of low } \\
\text { bank elevation }{ }^{1} \\
\text { (feet) }\end{array}$ & $\begin{array}{l}\text { Location } \\
\text { (fig. 2) }\end{array}$ \\
\hline \multirow[t]{4}{*}{ VII } & 14,520 & 7 & 27 & 40.8 & 9.7 & \\
\hline & & & 28 & 40.0 & 9.1 & \\
\hline & & & 29 & 39.1 & 8.7 & \\
\hline & & 8 & 30 & 38.1 & 8.7 & \\
\hline \multirow[t]{3}{*}{ VIII } & 7,920 & 8 & 30 & 38.1 & 8.7 & \\
\hline & & & 31 & 37.2 & 8.0 & \\
\hline & & 9 & 32 & 36.6 & 8.0 & \\
\hline \multirow[t]{4}{*}{ IX } & 15,840 & 9 & 32 & 36.6 & 8.0 & Site 3 \\
\hline & & & 33 & 35.6 & 8.0 & (Williamston) \\
\hline & & & 34 & 34.6 & 7.1 & \\
\hline & & 10 & 35 & 33.6 & 6.9 & \\
\hline \multirow[t]{3}{*}{$X$} & 15,050 & 10 & 35 & 33.6 & 6.9 & \\
\hline & & & 36 & 32.3 & 6.8 & \\
\hline & & 11 & 37 & 30.7 & 6.1 & \\
\hline \multirow[t]{4}{*}{ XI } & 21,650 & 11 & 37 & 30.7 & 6.1 & \\
\hline & & & 38 & 29.6 & 5.5 & \\
\hline & & & 39 & 27.8 & 5.5 & \\
\hline & & 12 & 40 & 26.6 & 4.1 & \\
\hline \multirow[t]{3}{*}{ XII } & 29,570 & 12 & 40 & 26.6 & 4.1 & \\
\hline & & & 41 & 25.5 & 4.0 & \\
\hline & & 13 & 42 & 21.0 & 2.7 & \\
\hline \multirow[t]{2}{*}{ XIII } & 8,710 & 13 & 43 & 21.0 & 3.1 & \\
\hline & & 14 & 44 & 19.4 & 2.0 & $\begin{array}{l}\text { Site } 4 \\
\text { (Jamesville) }\end{array}$ \\
\hline \multirow[t]{4}{*}{ XIV } & 18,216 & 7 & 45 & 40.8 & 9. & Head of \\
\hline & & & & 46 & 10.0 & Conine Creek \\
\hline & & & & 47 & 6.3 & \\
\hline & & 11 & 48 & 30.7 & 5.0 & $\begin{array}{l}\text { Mouth of } \\
\text { Conine Creek }\end{array}$ \\
\hline
\end{tabular}


Table 4.--Summary of branches and cross sections used in the flow model for the Roanoke River between the State Highway 11-42 bridge and Jamesville--Continued

\begin{tabular}{|c|c|c|c|c|c|c|}
\hline Branch & $\begin{array}{l}\text { Branch } \\
\text { length } \\
\text { (feet) }\end{array}$ & Junction & $\begin{array}{l}\text { Cross } \\
\text { section }\end{array}$ & $\begin{array}{c}\text { River } \\
\text { mile }\end{array}$ & $\begin{array}{l}\text { Approximate } \\
\text { top of low } \\
\text { bank elevation } \\
\text { (feet) }\end{array}$ & $\begin{array}{l}\text { Location } \\
\text { (fig. 2) }\end{array}$ \\
\hline \multirow[t]{4}{*}{ XV } & 55,280 & 15 & 49 & & 9.6 & \\
\hline & & & 50 & & 9.6 & \\
\hline & & & 51 & & 8.6 & \\
\hline & & 8 & 52 & 38.1 & 8.6 & $\begin{array}{l}\text { Mouth of } \\
\text { Conoho Creek }\end{array}$ \\
\hline \multirow[t]{7}{*}{ XVI } & 43,560 & 10 & 53 & 33.6 & 7.4 & Head of \\
\hline & & & 54 & & 6.3 & Devils Gut \\
\hline & & & 55 & & 5.8 & \\
\hline & & & 56 & & 5.3 & \\
\hline & & & 57 & & 4.4 & \\
\hline & & & 58 & & 3.5 & \\
\hline & & 13 & 59 & 21.0 & 2.4 & $\begin{array}{l}\text { Mouth of } \\
\text { Devils Gut }\end{array}$ \\
\hline
\end{tabular}

${ }^{1}$ Elevations of the top of bank were derived by linear interpolation of water-surface elevations between stage recorders.

The model has been calibrated only for water levels which are below the top of bank. Top of bank elevations are given in table 4 . The natural levee along the Roanoke River is breached, however, by numerous drainage canals and a few creeks, especially near the lower end of the study reach. These channels provide conduits for flow to move out of the river and into the flood plain during high water levels. As the water level falls, water slowly drains back into the river. This process, which is different from water spilling over the top of the bank during high flows, has been accommodated in the model.

\section{Calibration}

Model calibration is required to adapt the general branch-network flow model to the specific application in the Roanoke River. Calibration is accomplished by adjusting model parameters until model results agree with observations. Essentially, all components of the model schematization are subject to adjustment during model calibration. Components that are directly measurable and physically well defined, however, typically are less subject to adjustment than components or values that cannot be directly measured.

Factors that were adjusted during calibration of the lower Roanoke River flow model include the following: 
Computational time step: A time step of 15 minutes gave the best results. Fifteenminute interval input data from the upstream and downstream boundaries are linearly interpolated from the hourly observations at the State Highway 11-42 bridge near Oak City and at the U.S. Highway 17 bridge near Williamston, respectively.

Channel geometry and branches: The Oak City-to-Williamston reach is represented by 9 branches and 35 cross sections (fig. 9 and table 4). Cross sections in the reach are based on direct measurements. Elevations relative to sea level were obtained by (1) measuring channel geometry, including the stream banks, and referencing measurements to the water surface, (2) determining the water-surface elevation at the stage recorders upstream and downstream from the section at the time the section was measured, and (3) linearly interpolating between the two recorders to obtain the water-surface elevation at the section. Adjustments to cross-sectional area at some of the sections were required during the calibration process. These adjustments generally were at the higher stages, where direct measurements of cross-sectional geometry were more difficult.

Roughness coefficient: The roughness coefficient accounts for dissipation of energy from the main flow as heat by turbulence. Roughness coefficients initially were estimated using handbook values and the Manning flow equation. The coefficients were then adjusted to provide the best simulations. Within the calibrated model, the roughness coefficient is specified as a function of depth of flow at each cross section. The roughness coefficients range from 0.034 to 0.048 , with the higher values generally applying to the lower flow depths. Several simulations demonstrated that the computed water levels were quite insensitive to the value used for the roughness coefficient; discharge was moderately sensitive to the values selected.

Momentum coefficient: The momentum coefficient corrects for the effects of nonuniform velocity distributions on flows. A value of 1.06 , which is typical for turbulent flows in natural channels (Schaffranek and others, 1981), was used.

Weighting factors for numerical solution: Two factors, beta and chi, are used in the numerical solution of the governing equations. Beta controls the amount of numerical instability in the solution, and chi controls the phase lag in the solution. Based on experience in other applications (Schaffranek and others, 1981), beta was set to 1.00 and chi was set to 0.6 .

Boundary conditions at external junctions are required for model operation. Observed records of water level at sites 1 and 3 were used to supply the needed information. Initial flow and water-level conditions also are required for the modeled reach. A linearly sloping water surface and a constant flow were assumed to be initial conditions throughout the reach. Because initial conditions are not known exactly, computations near the beginning of the simulation period are not reliable. Consequently, a "warm-up" period is required for the effects of the initial conditions to be transported out of the reach.

Initial simulations provided good results at Hamilton (site 2) for a wide range of flow conditions. Good results also were obtained at Williamston for low flows, but results at higher flows were not acceptable. Results indicated that storage and release of water from the wetlands along the Roanoke River were not being simulated properly. This problem was solved by treating Conoho Creek as a large reservoir connected to the Roanoke River by a 
small channel. As the water level rose above about $5 \mathrm{ft}$, the reservoir began to fill slowly; as the water level fell, water was slowly released from the reservoir, simulating the slow release of water from the wetlands along the Roanoke River.

The last adjustment made during model calibration was the addition of local inflows. The drainage area between Oak City and Williamston contributes additional flow to the Roanoke River. This inflow, however, is time varying and ungaged. Because the quantity of inflow is unknown, a constant inflow totaling $265 \mathrm{ft}^{3} / \mathrm{s}$, which is equal to the long-term average inflow rate for the local drainage area (Krug and others, 1990), was added to the river.

Tests were made for three sets of arbitrarily selected water-level conditions. Water levels above about $9 \mathrm{ft}$ at site 2 were designated as high water levels; mid-range water levels were between about $9 \mathrm{ft}$ and about $6 \mathrm{ft}$, and low water levels were less than about $6 \mathrm{ft}$.

Computed and observed water-level values at Hamilton (site 2) typically differed by less than $0.5 \mathrm{ft}$ (fig. 10 and table 5). The difference between the observed and computed depth of flow generally was less than 5 percent.

Comparison of observed and computed flows at sites 1,2,3, and river mile 40.8 showed that the maximum absolute difference between measured and computed values was 16 percent, and the average difference for all 24 values was -7 percent (fig. 11 and table 5). These results compare quite favorably with results obtained using the one-dimensional flow model in other studies (for example Arcement, 1988; Carswell and others, 1988). Actual flow measurements, which are used to develop stage-discharge ratings, generally are considered to have an accuracy of no better than 5 percent. Hence, these flow simulations compare favorably with discharges computed from stage-discharge relations in other streams.

\section{Validation}

The flow model is considered to be validated if model results agree with observations distinct from those used for model calibration without further adjustment of model parameters. The calibrated model was used to simulate water level and discharge in the Roanoke River between Oak City and Williamston for three sets of river water-level conditions. No further adjustments in model parameters were made.

Results of the model validation showed that observed and simulated water levels at Hamilton (site 2) were in good agreement (fig. 12 and table 5). Likewise, observed and computed flows at sites 1, 2, and 3 were in excellent agreement during high to low waterlevel conditions (fig. 13 and table 5). Hence, the model can be considered validated for the range of conditions tested. 


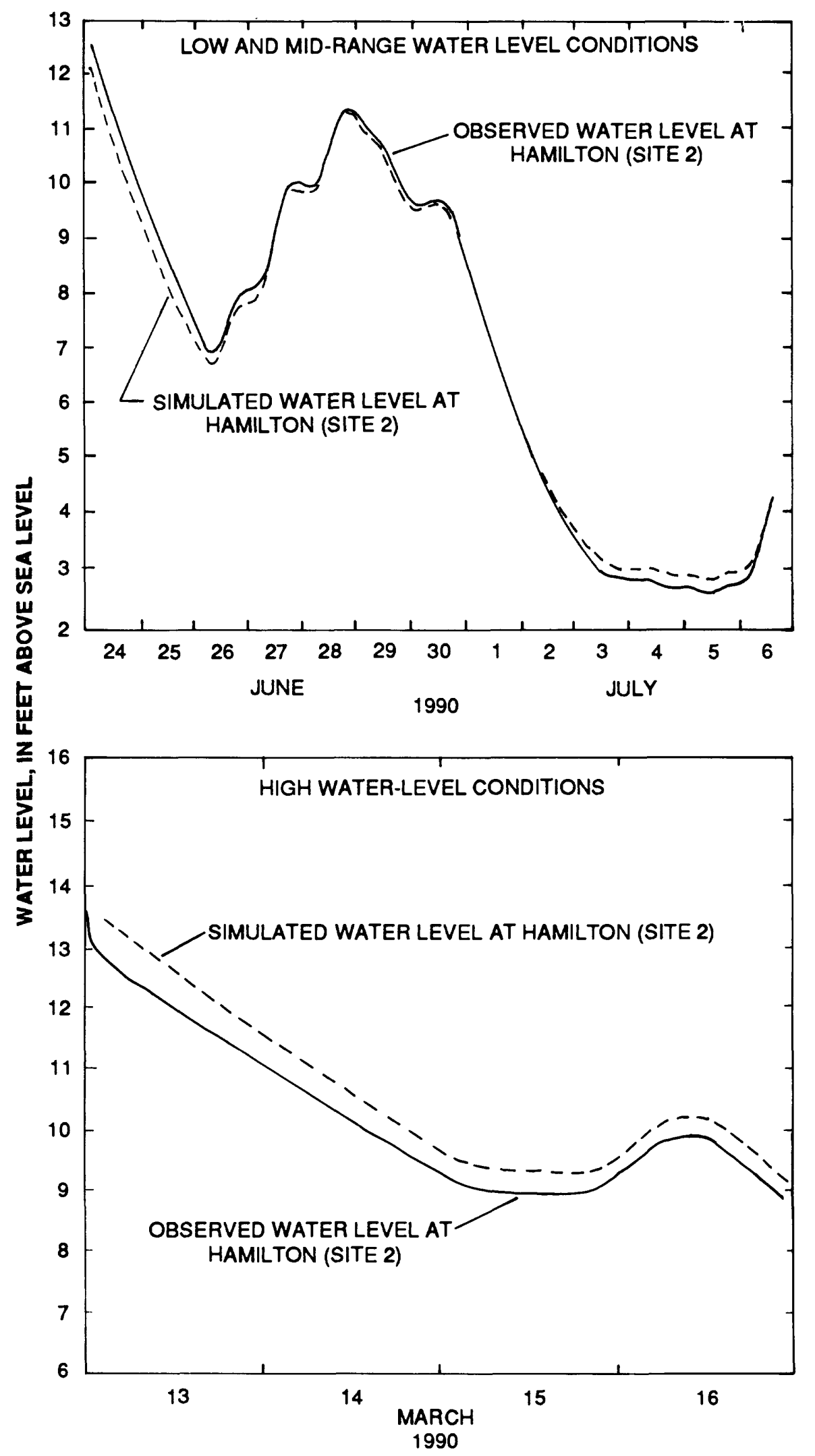

Figure 10. Observed and simulated water level at Hamilton for low and midrange (June 24-July 6, 1990) and high (March 13-16, 1990) water-level conditions for model calibration. 
Table 5.--Measured flows and flows computed using branch-network model for Roanoke River study-reach model calibration and validation

[ $\mathrm{ft}^{3} / \mathrm{s}$, cubic feet per second; C, calibration; RM, river mile; $\mathrm{V}$, validation]

\begin{tabular}{|c|c|c|c|c|c|c|c|}
\hline $\begin{array}{l}\text { Location } \\
\text { (fig. 2) }\end{array}$ & Date & $\begin{array}{c}\text { Time } \\
\text { (hours) }\end{array}$ & $\begin{array}{l}\text { Model } \\
\text { applica- } \\
\text { cation }\end{array}$ & $\begin{array}{c}\text { Water- } \\
\text { level } \\
\text { condition }\end{array}$ & $\begin{array}{c}\text { Measured } \\
\text { flow } \\
\left(\mathrm{ft}^{3} / \mathrm{s}\right)\end{array}$ & $\begin{array}{c}\text { Computed } \\
\text { flow } \\
\left(\mathrm{ft}^{3} / \mathrm{s}\right)\end{array}$ & $\begin{array}{c}\text { Percent } \\
\text { difference }\end{array}$ \\
\hline Site 2 & $3-13-90$ & 1200 & $\mathrm{C}$ & High & 8,170 & 9,489 & 16 \\
\hline Site 3 & $3-14-90$ & 0930 & $\mathrm{C}$ & High & 10,710 & 9,345 & -13 \\
\hline Site 3 & $3-16-90$ & 1015 & $\mathrm{C}$ & High & 9,000 & 8,832 & -2 \\
\hline Site 1 & $6-26-90$ & 1730 & $\mathrm{C}$ & Low & 5,590 & 5,955 & 7 \\
\hline Site 3 & $6-26-90$ & 0945 & $\mathrm{C}$ & Mid-range & 6,510 & 5,804 & -11 \\
\hline Site 3 & $6-26-90$ & 1130 & $\mathrm{C}$ & Mid-range & 6,550 & 5,746 & -12 \\
\hline Site 3 & $6-26-90$ & 1530 & $\mathrm{C}$ & Mid-range & 6,800 & 6,014 & -12 \\
\hline RM 40.8 & $6-26-90$ & 1215 & $\mathrm{C}$ & Mid-range & 5,280 & 4,617 & -13 \\
\hline Site 2 & $6-27-90$ & 1315 & $\mathrm{C}$ & Mid-range & 7,820 & 7,933 & 2 \\
\hline Site 3 & $6-27-90$ & 0900 & $\mathrm{C}$ & Mid-range & 7,230 & 6,940 & -4 \\
\hline Site 1 & $6-28-90$ & 1200 & $\mathrm{C}$ & Mid-range & 9,780 & 10,056 & 3 \\
\hline Site 1 & $6-29-90$ & 1330 & $\mathrm{C}$ & Mid-range & 8,100 & 8,556 & 6 \\
\hline Site 2 & $6-29-90$ & 1115 & $\mathrm{C}$ & Mid-range & 8,780 & 9,125 & -4 \\
\hline Site 3 & $6-29-90$ & 0900 & $\mathrm{C}$ & Mid-range & 8,990 & 9,942 & 11 \\
\hline RM 40.8 & $7-05-90$ & 1500 & $\mathrm{C}$ & Low & 2,010 & 2,064 & 3 \\
\hline Site 3 & $7-05-90$ & 1730 & $\mathrm{C}$ & Low & 2,180 & 2,363 & 8 \\
\hline Site 1 & $7-06-90$ & 1115 & $\mathrm{C}$ & Low & 4,150 & 3,890 & -6 \\
\hline Site 2 & $7-06-90$ & 1445 & $\mathrm{C}$ & Low & 4,140 & 3,769 & -9 \\
\hline Site 1 & $5-04-90$ & 1015 & V & Mid-range & 8,520 & 8,953 & 5 \\
\hline Site 2 & $5-04-90$ & 1315 & V & Mid-range & 8,480 & 8,939 & 5 \\
\hline Site 3 & $5-04-90$ & 1545 & V & Mid-range & 8,730 & 8,839 & 1 \\
\hline Site 3 & $7-28-90$ & 1030 & V & Low & 3,850 & 3,697 & -4 \\
\hline Site 3 & $3-20-91$ & 1345 & V & High & 10,750 & 11,111 & 3 \\
\hline Site 3 & $3-22-91$ & 1415 & $\mathrm{~V}$ & High & 11,970 & 13,511 & 13 \\
\hline
\end{tabular}



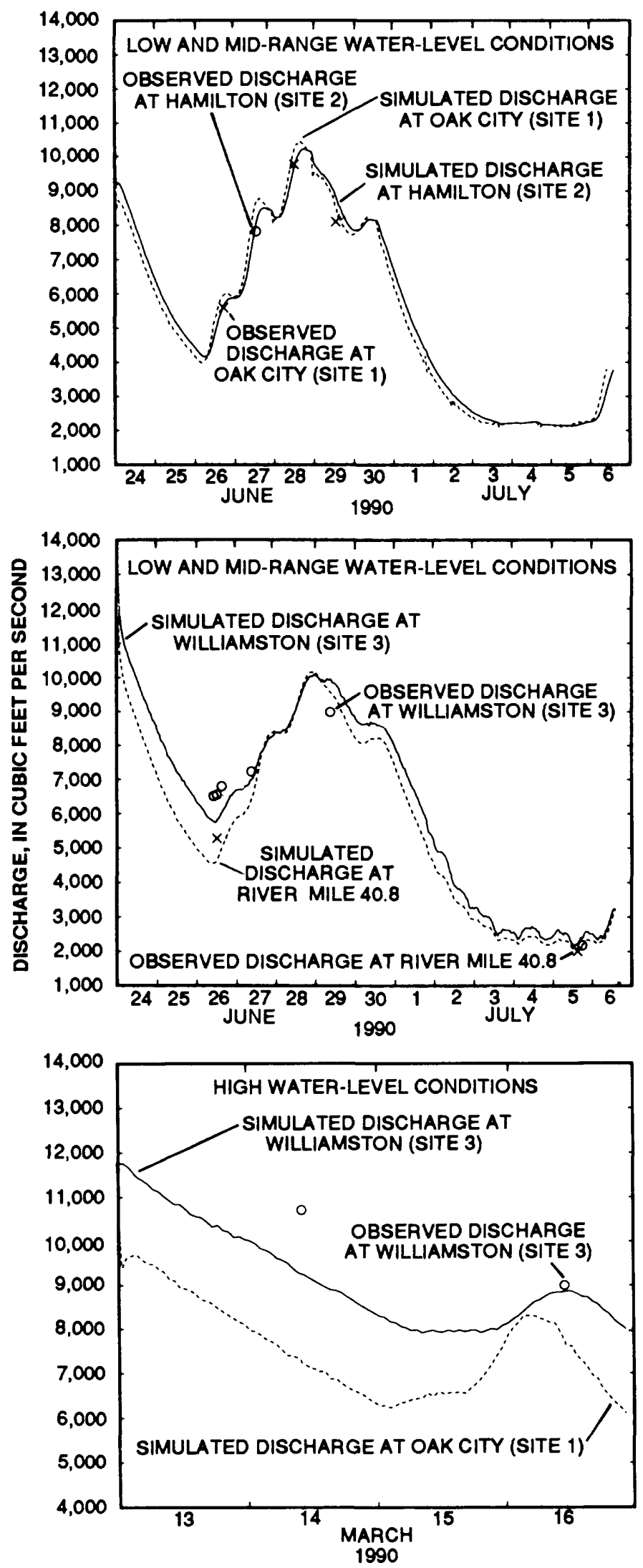

Figure 11. Observed and simulated discharge at Hamilton, Oak City, River Mile 40.8, and Williamston for low and mid-range (June 24-July 6, 1990) water-level conditions, and at Oak City and Williamston for high (March 13-16, 1990) water-level conditions for model calibration. 

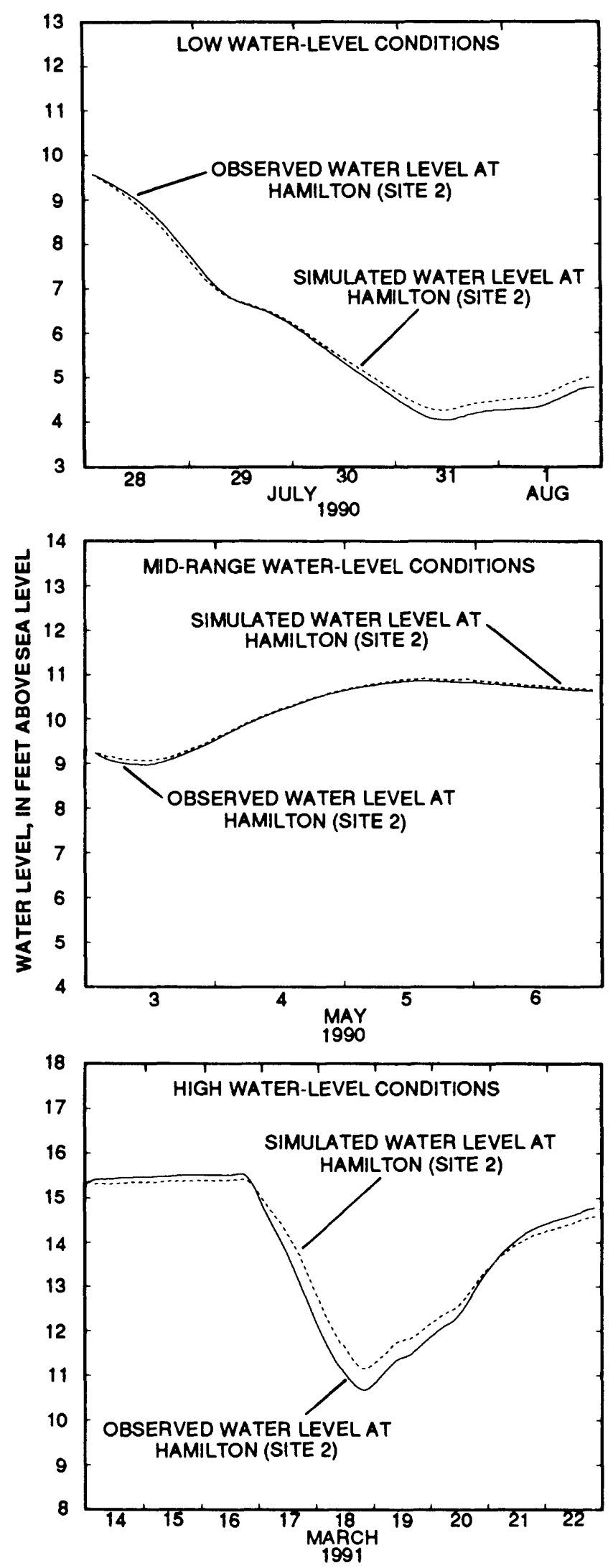

Figure 12. Observed and simulated water level at Hamilton for low (July 28-August 1, 1990), mid-range (May 3-6, 1990), and high (March 14-22, 1991) water-level conditions for model validation. 

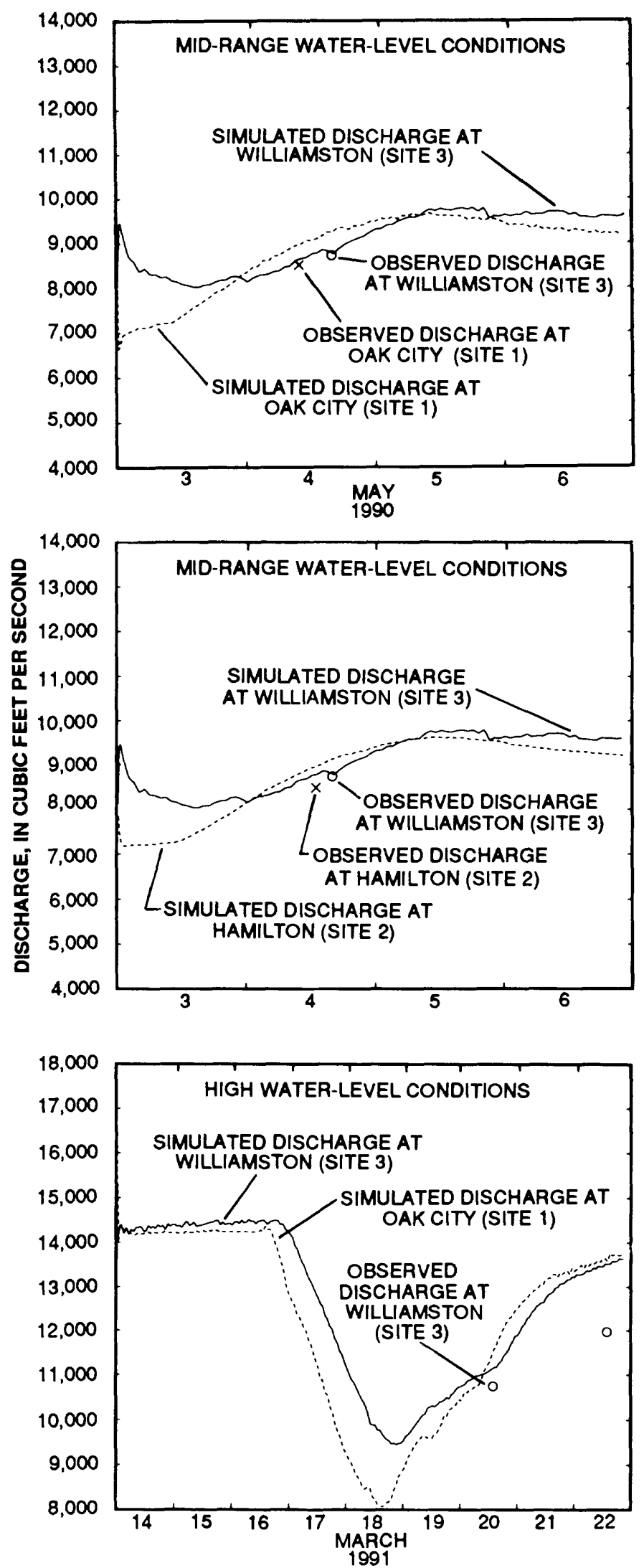

Figure 13. Observed and simulated discharge at Oak City, Hamilton, and Williamston for mid-range (May 3-6, 1990) water-level conditions, and at Oak City and Williamston for high (March 14-22, 1991) water-level conditions for model validation. 


\section{Plans for Model Completion}

Plans for completion of the modeling effort include testing the sensitivity of the Oak City-to-Williamston model results to small changes in model parameters. The parameters to be tested include the roughness coefficient, the two numerical-scheme weighting parameters, the momentum coefficient, gage datum at the three water-level recorder sites, and the characteristics of the storage reservoir.

Plans also call for the model to be expanded in increments to include the reach between Williamston and Albemarle Sound (fig. 14), and modification of the model to address the effects of wind on flows in the distributary. Preliminary results for the Oak City-toJamesville reach indicate the model is capable of reproducing observed water levels at sites 2 (Hamilton) and 3 (Williamston) (fig. 15). Following development, calibration, validation, and sensitivity testing of the expanded flow model, it is intended that flows will be simulated in the Roanoke River for a variety of conditions. Flows will be simulated, however, only for periods for which water-level data are available at the boundaries.

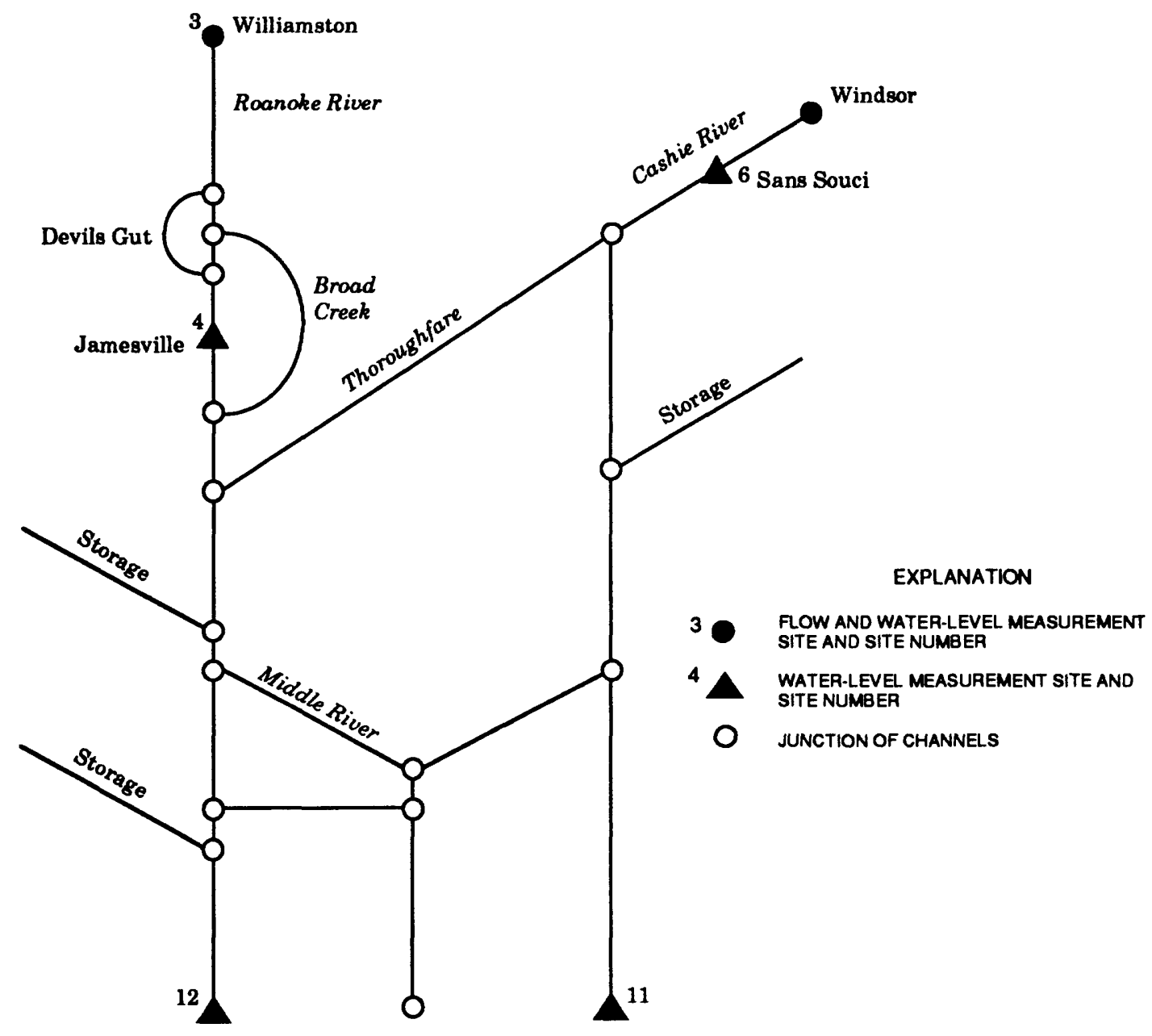

Albemarle Sound

Figure 14. Data-collection sites and model schematization for the Roanoke River between Williamston and Albemarle Sound. 


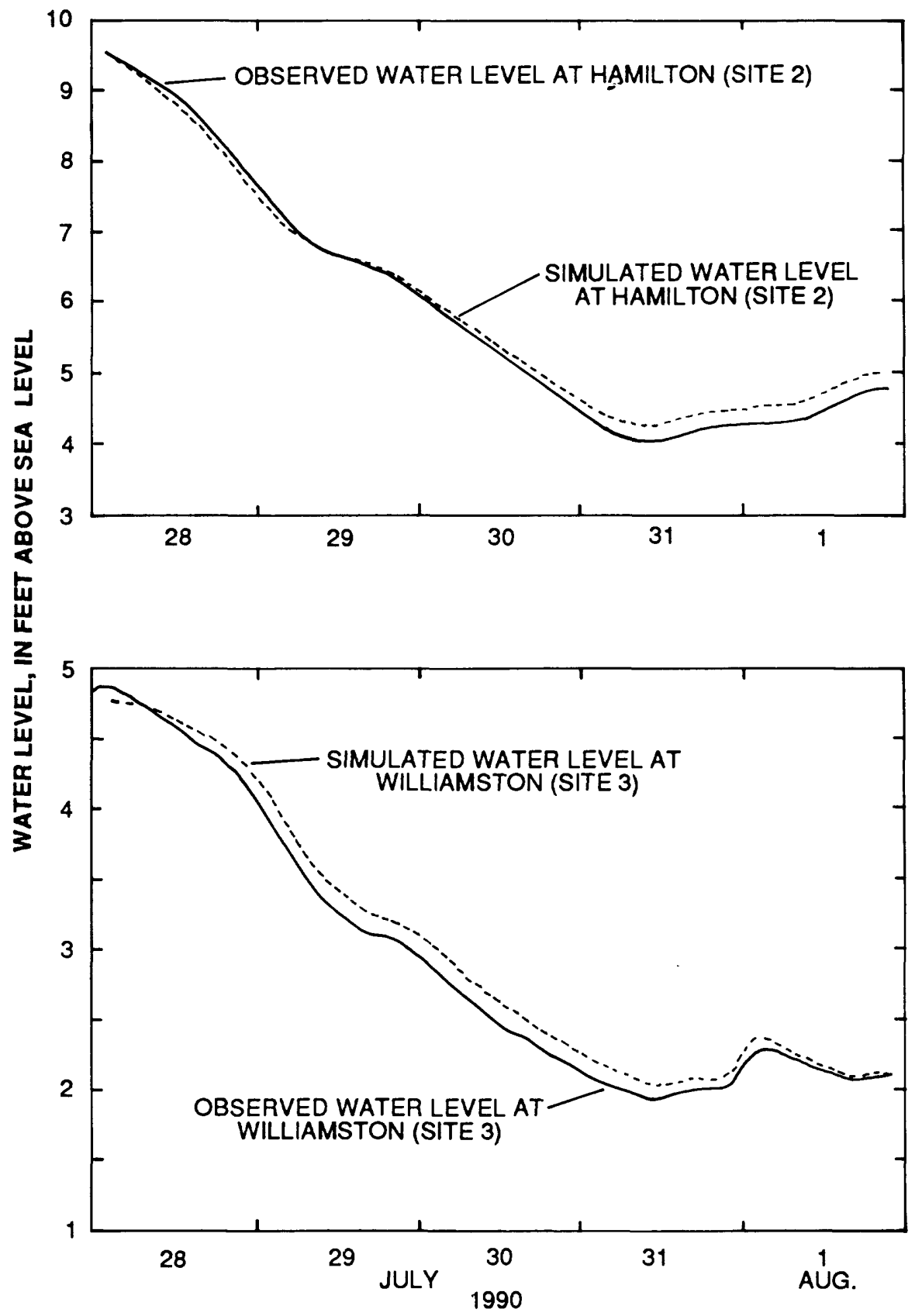

Figure 15. Observed and model-simulated water levels at Hamilton and at Williamston.

It also is intended that the completed model will be used to simulate flows for the 1991 striped bass egg sampling period of approximately April 15 to June 15 to provide linkage between the physical and biological systems. Results can provide information on approximate travel times (based on flow velocity) of eggs and larvae from Oak City to Albemarle Sound for the 1991 spawning season. (Note: travel times determined in this manner will be approximate because the model is a flow model, not a transport model.) Based on the simulated distribution of flows in the delta, the paths that larvae take through the Roanoke River distributary system for the 1991 spawning season can be estimated. Standing crops of phytoplankton and zooplankton for periods of interest may be determined in the distributary by using the flow model and the 1991 biological sampling results. 
Based on the model-generated mean velocities in the study reach, plans are to estimate the approximate traveI time from Oak City to Albemarle Sound. Steady flows of 2,000,5,000, 15,000 , and perhaps $20,000 \mathrm{ft}^{3} / \mathrm{s}$ would be modeled using downstream boundary water levels held constant at two values--an average high spring condition and an average low spring condition. This procedure, then, could result in six to eight sets of simulations. These results should provide information on approximate travel times for eggs and larvae from Oak City to Albemarle Sound under the simulated flow conditions. The distribution of flows in the delta also may be quantified for the different flow conditions. The extent to which flow distribution provides an indication of distribution of larval fish, phytoplankton, and zooplankton in the delta will be known from the analyses of the 1991 sampling data and concurrent flow simulations.

ModeI results and information on topography stored in the GIS are proposed to be used to determine the approximate flow rates at which channel banks are overtopped for the Roanoke River from Oak City to Albemarle Sound. Results could be provided as flow rate at which banks are overtopped as a function of location and Albemarle Sound water level. This information may give an indication of the flow rates at which eggs and larval fish may be lost to the flood plain.

\section{CONTINUOUSLY MONITORED WATER QUALITY IN ALBEMARLE SOUND}

Estuarine environmental monitoring has been defined as "a continuing program of modeling, measurement, analysis, and synthesis that predicts and quantifies environmental conditions or contaminants and incorporates that information effectively into decision making in environmental management" (National Research Council, 1990, p. 2). Monitoring data can provide information needed by resource managers and regulators to (1) evaluate pollution abatement activities and control waste discharges, (2) measure trends in water quality, (3) detect new environmental problems in their early stages, potentially leading to lower-cost solutions, (4) evaluate human health hazards, and (5) determine the response of organisms to changes in habitat quality (National Academy of Sciences, 1977; Pearce and Despres-Patanjo, 1988; National Research Council, 1990).

The estuarine environment is extremely complex and highly variable, and it is often difficult to detect changes or to separate trends from natural variations. For example, salinity may be affected by tides, variable freshwater inputs, meteorological conditions, bathymetry, sea-Ievel rise, and other factors, all of which are temporally and spatially variable. Moreover, there is a physical coupling between salinity and the flow field. Flows can be generated by spatial salinity (density) gradients. The flow field, in turn, advects and mixes salt, and thereby affects the spatial salinity gradients. Salinity also is an important biological factor affecting species productivity and diversity, and may be related to the initial manifestation of certain finfish diseases (Noga and Stanley, 1989).

Likewise, dissolved oxygen fluctuates in response to flows, to the salinity-controlled density field, to diurnal and vertical variations in community metabolism, and to variable water-quality conditions. Because vertical density gradients control the transport of oxygen through the water column, salinity distributions and dissolved-oxygen concentrations are closely related. Adequate dissolved-oxygen levels are required to maintain acceptable fisheries habitat in Albemarle Sound (Coutant, 1985; Kornegay, 1988). Suitable habitat for 
striped bass generally has water temperatures less than $25^{\circ} \mathrm{C}$ and dissolved-oxygen concentrations greater than $5 \mathrm{mg} / \mathrm{L}$ (milligrams per liter) (Coutant, 1985).

Because of the complex and variable nature of estuaries, continuous water-quality monitors can play a key role in monitoring habitat quality. For example, evaluation of data collected at bimonthly intervals in the Chesapeake Bay indicated the need for continuously monitored salinity, dissolved-oxygen, and temperature data (Martin Marietta Environmental Systems, 1987a and 1987b). As an example of the use of continuous water-quality monitoring in environmental studies, near-bottom dissolved oxygen was continuously monitored during the summer of 1990 at 30 estuarine sites from Massachusetts to Virginia (Holland, 1990) as part of the Environmental Monitoring and Assessment Program recently initiated by the U.S. Environmental Protection Agency.

The Albemarle-Pamlico (A-P) Estuarine Study implemented an estuarine monitoring program in 1988 (Holman, 1988). The monitoring program includes an expanded ambientmonitoring network, fish tissue analysis, sediment oxygen demand studies, a citizens' monitoring program, and a network of continuous water-quality monitors. The expanded ambient-monitoring network and the continuous-monitoring network were designed to provide compatible data, and, in many locations, the ambient- and continuous-monitoring network sites coincide.

In 1988, the U.S. Geological Survey, in cooperation with the North Carolina Department of Environment, Health, and Natural Resources, initiated an investigation of water quality at 33 sites in the Albemarle-Pamlico Sounds. Ten of those sites are in or near Albemarle Sound (sites 1-10, table 6; fig. 16). The investigation involves measurements at 15minute intervals of near-surface and near-bottom specific conductance; near-surface water temperature; and near-surface, mid-depth, and near-bottom dissolved-oxygen concentrations. These data are used to (1) characterize baseline conditions; (2) evaluate temporal trends after sufficient data are available; (3) characterize the extent, frequency, and duration of density stratification; (4) describe the dissolved-oxygen regime, including the relation of hypoxia to density stratification; and (5) provide information required for hydrodynamic and water-quality modeling.

This section (1) provides details on data-collection procedures, (2) summarizes data collected at 5 of the 10 water-quality monitoring sites, and (3) presents preliminary analyses of data from the five sites. Data from all sites were not available for presentation in this report. Data presented in this interim report include near-surface and near-bottom specific conductance; near-surface and near-bottom salinity obtained from measurements of specific conductance; near-surface water temperature; and near-surface, mid-depth, and near-bottom dissolved-oxygen concentrations at sites 1-5 (table 6). The period of record differs from site to site, but the earliest record available is for October 1989, and the latest is for April 1991. 
Table 6.--Continuous water-quality monitoring locations

in and near Albemarle Sound

[USGS, U.S. Geological Survey; U.S. Hwy., U.S. Highway; 1t., light]

Site

number

(fig. 16)

Location

Latitude

USGS

Longitude station number

1 Chowan River U.S. Hwy. 17 bridge

2 Roanoke River lt. 1

$36^{\circ} 02^{\prime} 52^{\prime \prime} \quad 76^{\circ} 41^{\prime} 42^{\prime \prime} \quad 0205365200$

$35^{\circ} 57^{\prime} 17^{\prime \prime} \quad 76^{\circ} 39^{\prime} 52^{\prime \prime} \quad 0208411443$

3 Albemarle Sound lt. 3

$36^{\circ} 00^{\prime} 06^{\prime \prime} \quad 76^{\circ} 23^{\prime} 36^{\prime \prime} \quad 0208115600$

4 Pasquotank River Slue 1t. 1

$36^{\circ} 09^{\prime} 06^{\prime \prime} \quad 76^{\circ} 01^{\prime} 18^{\prime \prime}$

0204387900

5 Currituck Sound U.S. Hwy. 158 bridge

$36^{\circ} 05^{\prime} 12^{\prime \prime} \quad 76^{\circ} 46^{\prime} 06^{\prime \prime}$

0204295500

6 Chowan River 1t. 22

$36^{\circ} 21^{\prime} 48^{\prime \prime} \quad 76^{\circ} 46^{\prime} 42^{\prime \prime} \quad 0205338780$

7 Chowan River lt. 5

$36^{\circ} 10^{\prime} 02^{\prime \prime} \quad 76^{\circ} 44^{\prime} 38^{\prime \prime}$

0205363590

8 Alligator River 1t. 8

$35^{\circ} 55^{\prime} 58^{\prime \prime} \quad 76^{\circ} 59^{\prime} 47^{\prime \prime}$

0208117835

9 Croatan Sound U.S. Hwy. 264 bridge

$35^{\circ} 55^{\prime} 00^{\prime \prime} \quad 75^{\circ} 44^{\prime} 50^{\prime \prime}$

0208117950

10 Roanoke Sound Channel lt. 22

$35^{\circ} 53^{\prime} 00^{\prime \prime} \quad 75^{\circ} 37^{\prime} 30^{\prime \prime}$

0208117980

\section{Albemarle Sound Study Area}

Albemarle Sound drains an $18,359 \mathrm{mi}^{2}$ area in North Carolina and Virginia, and has a surface area of about $480 \mathrm{mi}^{2}$ (fig. 16). Seven lateral estuaries (Chowan, Perquimans, Little, Pasquotank, North, Alligator, and Scuppernong Rivers) and Currituck Sound surround Albemarle Sound and contribute an additional $500 \mathrm{mi}^{2}$ of water-surface area to the system. Although depths are as much as $30 \mathrm{ft}$ in some parts of the sound, the average depth is $11.5 \mathrm{ft}$, and depths seldom exceed $20 \mathrm{ft}$ (Giese and others, 1985).

The net annual-average inflow to Albemarle Sound is about $17,000 \mathrm{ft}^{3} / \mathrm{s}$, of which more than half $\left(8,900 \mathrm{ft}^{3} / \mathrm{s}\right)$ is supplied by the Roanoke River through a network of distributaries at the western end of the sound. More than 50 percent of the inflow to Pamlico Sound is from Albemarle Sound. Because of the relatively high freshwater inflows and the absence of a direct connection with the ocean, salinities in Albemarle Sound are typically less than $5 \mathrm{ppt}$ (parts per thousand) (Copeland and others, 1983). Inflows generally contain low sediment loads, although the waters of the sound have been classified as turbid (Copeland and others, 1983). Much of the bottom of the sound consists of silt and clay (Wells, 1989). This fact indicates that resuspension and transport of these fine-grained materials may play an important role in water-quality processes in the sound. 


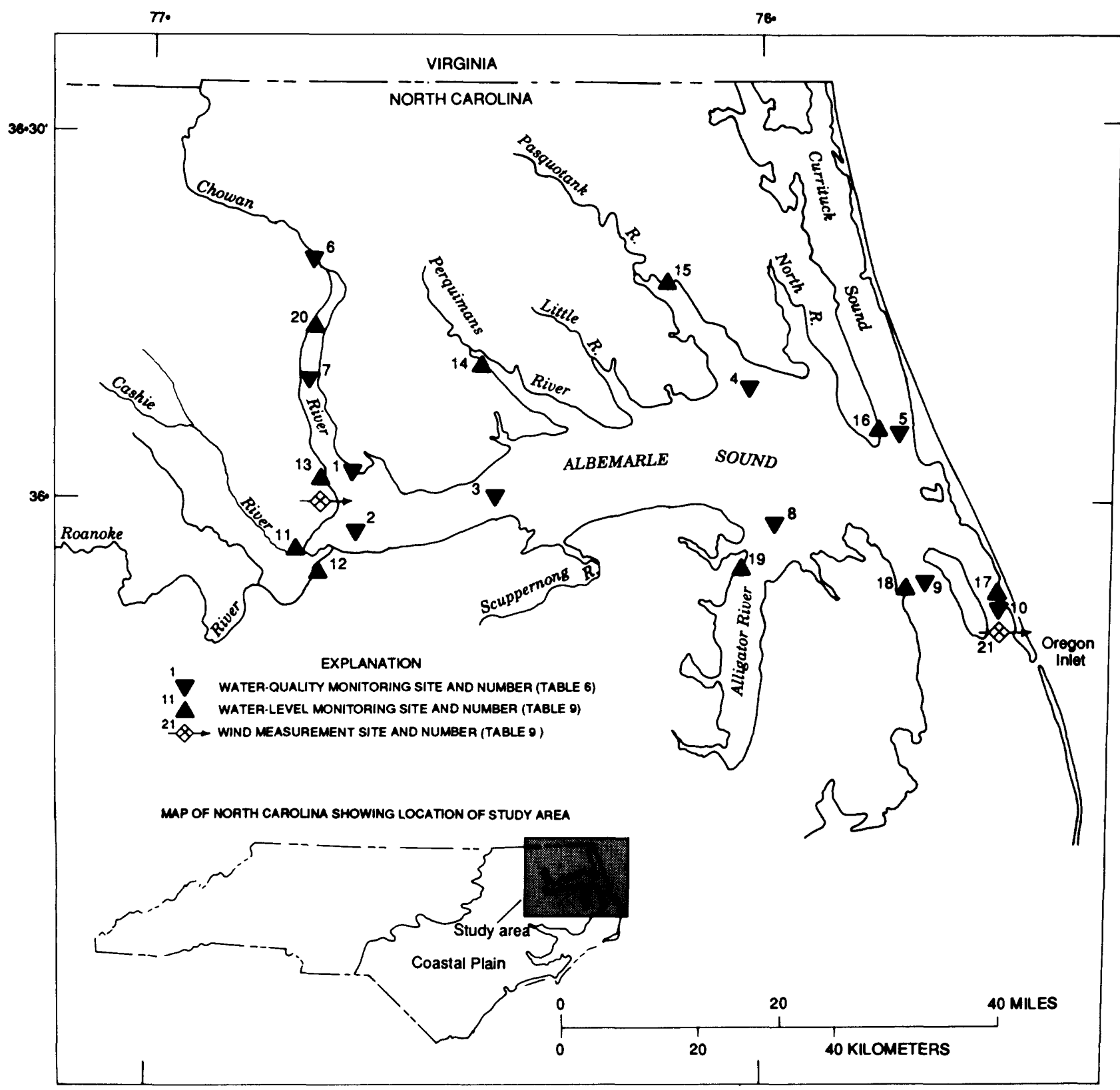

Figure 16. Albemarle Sound data-collection network.

\section{Collection and Analyses of Data}

Standard USGS procedures for the collection and analysis of water-quality data were followed. Procedures for servicing data-collection instrumentation and for processing the data were also developed and documented for the specific instrumentation and conditions of this study.

\section{Instrumentation}

The central component of the data-collection system is the USGS minimonitor (Gordon and Katzenbach, 1983; Ficken and Scott, 1989). The minimonitor consists of (1) a water-tight 
can (about 14.5 in. high by 10.5 in. in diameter) containing signal conditioners, (2) cables with waterproof connectors, (3) water-quality sensors, and (4) a 12-volt battery. The minimonitor may have up to eight water-quality sensors; available sensors include temperature, specific conductance, dissolved oxygen, and $\mathrm{pH}$. In this investigation, $\mathrm{pH}$ was not measured. The standard temperature range for the USGS minimonitor is from 0 to $50{ }^{\circ} \mathrm{C}$; for a calibrated system, temperature measurements are accurate to within 1 percent of full scale. The specific conductance sensor for the minimonitor uses four electrodes to reduce the effects of fouling. Compensation for ambient water temperature is made by the signal conditioner so that all specific-conductance values are referenced to a temperature of $25^{\circ} \mathrm{C}$. Measurement scales for specific conductance with ranges from 0 to 100,1,000,10,000, or $100,000 \mu \mathrm{S} / \mathrm{cm}$ (microsiemens per centimeter) may be selected on the minimonitor.

Following calibration, specific conductance measurements are accurate to within 3 percent of full scale in a temperature range from 0 to $40^{\circ} \mathrm{C}$.

The dissolved-oxygen sensor uses a polarographic membrane and stirrer manufactured by Yellow Springs Instrument Company ${ }^{1}$, and an added signal conditioner designed by the USGS. The dissolved-oxygen measurement system is potentially subject to more types of errors than the temperature and specific conductance measurement systems. Potential errors include sensor background error, temperature-compensation uncertainty, and sensor-calibration uncertainty. Dissolved-oxygen measurements are estimated to be accurate within about $0.3 \mathrm{mg} / \mathrm{L}$ over the range of 0 to $20 \mathrm{mg} / \mathrm{L}$ for a calibrated system.

The minimonitor is controlled by a CR10 measurement and control module (Campbell Scientific, Inc., 1988). The CR10 is a fully programmable data logger and controller that will accept voltage inputs from multiple sensors. The CR10 is programmed to turn the minimonitor on at 15-minute intervals, allow the sensors to stabilize for 1 minute, collect data from each of the sensors, record the time, and turn the minimonitor off. An external 12volt battery provides power to the CR10. The CR10 has sufficient internal memory to store about 30 days of minimonitor data collected at 15-minute intervals using six sensors. Data are lost, however, if the CR10 loses power.

To avoid potential problems associated with loss of power to the CR10 and to provide more operational flexibility, an SM192 storage module with nonvolatile memory (Campbell Scientific, Inc., 1987) is connected in series with the CR10. Data are automatically transferred from the CR10 to the SM192, which is not programmable and is only accessible through the CR10. The SM192 has an internal 3.5-volt battery to protect the memory when the module is disconnected from the external power supply. Memory capacity is sufficient to store about 3 months of minimonitor data.

All instruments are housed in water-tight shelters located on U.S. Coast Guard channel markers or on bridge fenders (fig. 16 and table 6). The data logger and storage module are further protected in a moisture-proof container within the shelter. Weights were added to the ends of the sensor cables to minimize current-induced vertical motion of the sensors. A reference mark with a known elevation above the seabed was established at each station to ensure that sensors are returned to the same point in the water column after servicing.

${ }^{1}$ Any use of trade, product, or firm names in this report is for descriptive purposes only and does not constitute endorsement by the U.S. Geological Survey. 


\section{Field Procedures}

Instruments are serviced at approximately 3-week intervals. During the colder months (October through April), servicing at 4- to 5-week intervals is sufficient, although the 3-week schedule is generally maintained. More frequent servicing may be necessary during the warmer months because of biofouling problems.

Field meters are calibrated in the laboratory prior to visiting the field installations. Field meters used were the Yellow Springs Instrument Company Model 33 S-C-T meter for specific conductance and the Yellow Springs Instrument Company Model 54 dissolvedoxygen meter. Both meters are also capable of measuring temperature. Temperature thermistors are calibrated against an American Society for Testing Materials (ASTM) thermometer at two temperatures. All values are within $0.5^{\circ} \mathrm{C}$ after calibration. Specific conductance standards are used to develop a calibration curve for each conductance meter. Field meter values are within 5 percent of the standards after calibration. The dissolvedoxygen meter is calibrated in water-saturated air adjusted for barometric pressure. After calibration, meter values are within $0.1 \mathrm{mg} / \mathrm{L}$ of the saturation value at the measured temperature and barometric pressure. Complete calibration records are maintained.

Simultaneous field-meter and minimonitor readings are made at coincident locations at the sites. If the difference between top and bottom readings for any of the sensors exceeds 5 percent, then field readings are made over the full depth of the water column. The sensors are then removed from the water and cleaned. Dissolved-oxygen probes are typically replaced during each visit.

After cleaning, sensors are returned to their original point in the water column, and a new set of field-meter and minimonitor readings are made. If necessary, the minimonitor span control for each measurement channel is adjusted until field and monitor readings agree. Storage modules containing recorded data are removed and replaced with modules prepared to begin recording a new set of data.

All minimonitors are calibrated with a full set of sensors in the laboratory prior to field installation. Consequently, if a sensor or sensor cable is replaced, a field calibration must be performed for that particular measurement channel. Standard solutions are used for specific conductance field calibrations. Dissolved-oxygen field calibrations are performed using a sodium sulfite solution to achieve an oxygen-depleted sample.

\section{Data Processing}

The storage modules are returned to the office and data are transferred to the data base. Corrections for the difference between minimonitor and field-meter readings are applied to the data. Salinity is computed from specific conductance records. Finally, plots of the data are made.

Data are reviewed to ensure validity. Outliers are examined and deleted if values are physically unrealistic. Water density, computed from salinity and temperature, is checked to ensure that near-bottom density equals or exceeds near-surface density. Data are rejected if the field-meter and minimonitor readings at the time of servicing are not in reasonable 
agreement. Finally, simple daily statistics are computed and final time-series plots are prepared.

\section{Presentation of Data}

Information on the beginning of record, water depth, sensor locations within the water column, and extreme values for salinity, temperature, and dissolved oxygen is given in table 7. Daily mean values of salinity, water temperature, and dissolved-oxygen concentration are presented in the Appendix for each of the five sites. Daily maximum and daily minimum plots are also included to graphically display variations throughout the year. The significant changes that occur in salinity and dissolved-oxygen concentrations at time scales of minutes and hours are not displayed in the plots. Daily maximum and minimum values, however, do give a good indication of the range of conditions at a site. Consequently, a reasonable summary of the large quantity of collected data is presented.

Table 7.--Maximum and minimum values for salinity, temperature, and dissolvedoxygen concentrations at water-quality monitoring sites 1-5 in

Albermarle Sound, 1989-91

Ippt, parts per thousand; ${ }^{\circ} \mathrm{C}$, degrees Celsius; $\mathrm{mg} / \mathrm{L}$, milligrams per liter;

Max, maximum value; Min, minimum value; --, no data available]

Sensor position

Site

(feet above bottom)

(fig. Mean Near Mid- Near Begin

16) depth surface depth bottom date

$\begin{array}{ccc}\text { Salinity } & \text { Temperature } & \begin{array}{c}\text { Dissolved } \\ \text { oxygen } \\ (\mathrm{ppt})\end{array} \\ \left({ }^{\circ} \mathrm{C}\right) & \mathrm{mg} / \mathrm{L})\end{array}$

Max Min Max Min Max Min

$\begin{array}{rrrrrrllllll}1 & 22 & 20 & 12 & 4 & 10-01-89 & 1.4 & 0.02 & 31.5 & 0.0 & 18.4 & 1.3 \\ 2 & 12 & 10 & 6 & 2 & 11-06-90 & 0.07 & .03 & -- & -- & 12.2 & 4.4 \\ 3 & 10 & 7 & 5 & 2 & 1-19-90 & 2.1 & .03 & 32.2 & 3.7 & 14.8 & 3.6 \\ 4 & 10 & 8 & 6 & 2 & 1-18-91 & 4.4 & .3 & 23.0 & 3.2 & 13.5 & 5.5 \\ 5 & 9 & 7 & 5 & 2 & 1-13-90 & 9.3 & .4 & 31.7 & 4.2 & 15.7 & 2.4\end{array}$

During the early phases of this investigation, high-quality data were obtained about 50-60 percent of the time. Lost record was a result of instrument failure and inadequate instrument calibration. As staff have gained experience with instrumentation, and as field and office procedures have improved, lost record has been reduced to less than 20 percent.

Throughout the tables and figures, temperature is presented as ${ }^{\circ} \mathrm{C}$. Salinity is given as ppt and is calculated from measured conductivity $\left(\mu \mathrm{S} / \mathrm{cm}\right.$ at $\left.25^{\circ} \mathrm{C}\right)$ using the formulation given by Miller and others (1988). Dissolved oxygen is presented as $\mathrm{mg} / \mathrm{L}$; no correction for the effects of salinity has been made in the dissolved-oxygen data presented in this report. 


\section{Preliminary Assessment of Data}

Salinities in Albemarle Sound range from essentially 0, or freshwater conditions, to more than $9 \mathrm{ppt}$ (table 7). The annual variation in water temperature is more than $30^{\circ} \mathrm{C}$, and dissolved-oxygen concentrations range from supersaturated to hypoxic conditions. With the exception of site 4 , where less than 4 months of data are available, dissolved-oxygen concentrations of less than $5 \mathrm{mg} / \mathrm{L}$ were observed at all sites.

The observed daily range (difference between daily maximum and minimum values) of salinity at each site generally is small. For example, at site 5, where the highest salinities of the 5 sites were observed, the daily salinity range was less than $1 \mathrm{ppt}$ for more than 75 percent of the days for which records were obtained. The maximum observed daily range in salinity was $3.0 \mathrm{ppt}$, and the minimum was $0.0 \mathrm{ppt}$. In comparison, the daily salinity range at site 3 typically was about $0.5 \mathrm{ppt}$, and the maximum observed range was $1.2 \mathrm{ppt}$.

Observed diurnal temperature fluctuations were likewise small. At site 3 , the mean daily temperature range was about $1.3^{\circ} \mathrm{C}$ for the period of record. The maximum observed daily range was $3.9^{\circ} \mathrm{C}$, and the minimum was $0.2^{\circ} \mathrm{C}$. For more than 50 percent of the days for which records were obtained, the daily range in dissolved-oxygen concentrations at site 3 was less than $1 \mathrm{mg} / \mathrm{L}$. The maximum daily range, however, was $6.8 \mathrm{mg} / \mathrm{L}$. As might be expected, the daily range in dissolved oxygen typically was higher during the summer months than during the rest of the year.

To give a better indication of short-term variability at a site, to illustrate longitudinal variations along the sound, and to give an indication of the difference between early spring and late summer conditions, boxplots were developed for near-surface and near-bottom salinity and for near-surface and near-bottom dissolved-oxygen concentration. The boxplots were developed using the 15-minute interval data, so each boxplot for a selected 5-day period represents about 480 observations.

Boxplots for near-surface and near-bottom salinity are shown for early spring (March 1-5, 1991) and late summer (August 6-10, 1990) conditions in figures 17 and 18, respectively. Salinities were quite low (less than $1 \mathrm{ppt}$ ) except at sites 4 and 5 . Salinities were higher during the late summer than during early spring at site 3 , but near-bottom salinities at site 5 were lower in the late summer than in the early spring. Within each of the 5-day periods, there generally was more fluctuation in salinity values during the early spring than during the late summer. There also was a greater difference between near-surface and near-bottom salinities during the early spring compared with late summer.

Dissolved-oxygen concentrations were higher during the early spring period than during the late summer period (figs. 19 and 20). They also were generally higher at site 3 , located near the east-west midpoint of Albemarle Sound, than at the other sites. Less fluctuation in dissolved-oxygen values was observed during the early spring period than during the late summer period, but during the late summer period, near-bottom values were more variable than near-surface values.

Before about April 20, when water temperatures were less than about $18^{\circ} \mathrm{C}$, dissolvedoxygen fluctuations at site 3 were negligible (fig. 21). As the water began to warm, well- 
defined, diurnal dissolved-oxygen fluctuations began to occur, presumably because of the onset of increased photosynthetic activity. Water temperatures, which were between 7.8 and $14.2^{\circ} \mathrm{C}$ during March 1-5, 1991, had not warmed sufficiently for photosynthetic activity to begin, thus causing the smaller range of dissolved-oxygen values in the early spring (fig. 19) relative to the late summer (fig. 20 ).

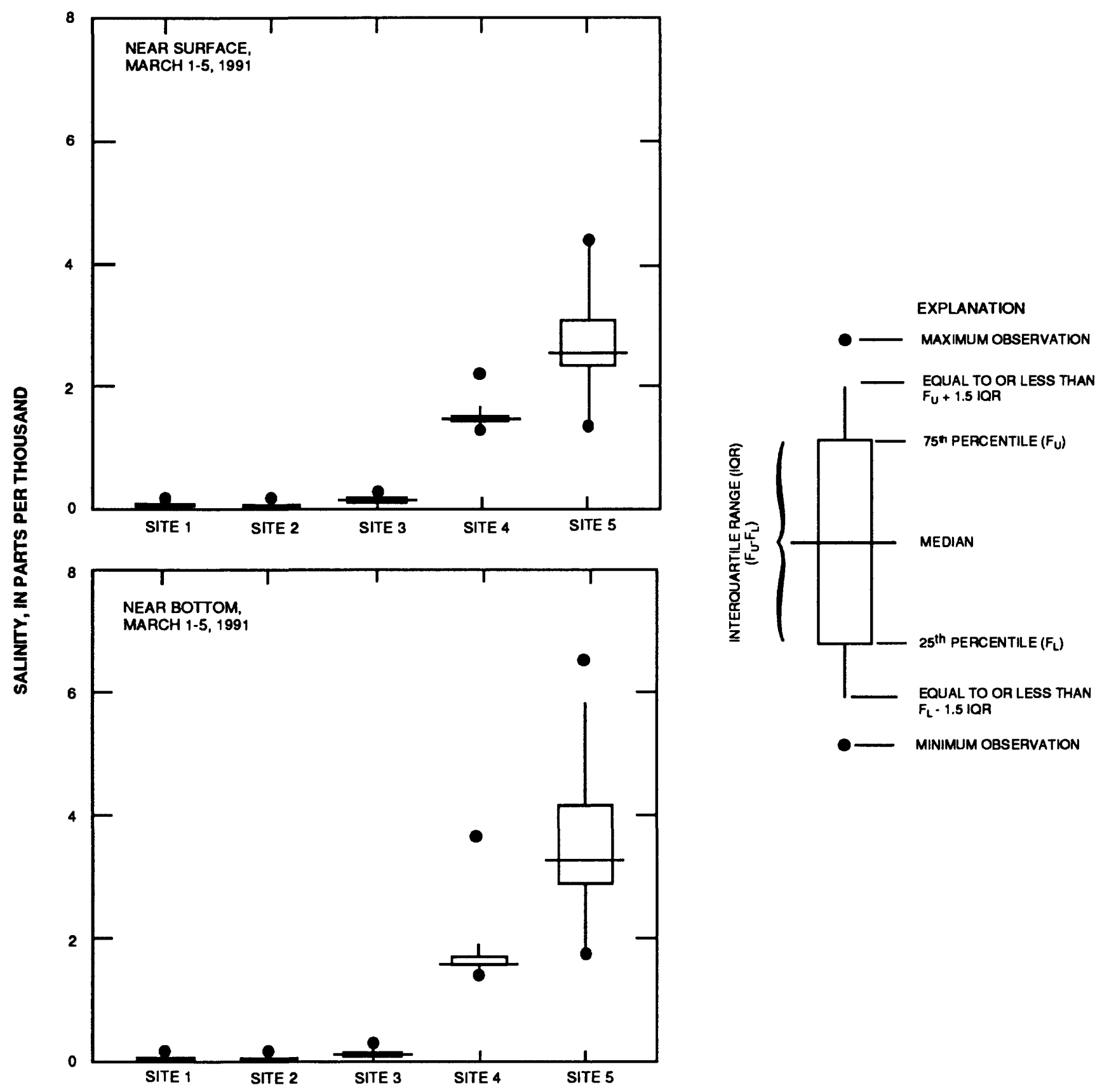

Figure 17. Salinity, near surface and near bottom, at sites 1-5 for early spring conditions, March 1-5, 1991. 


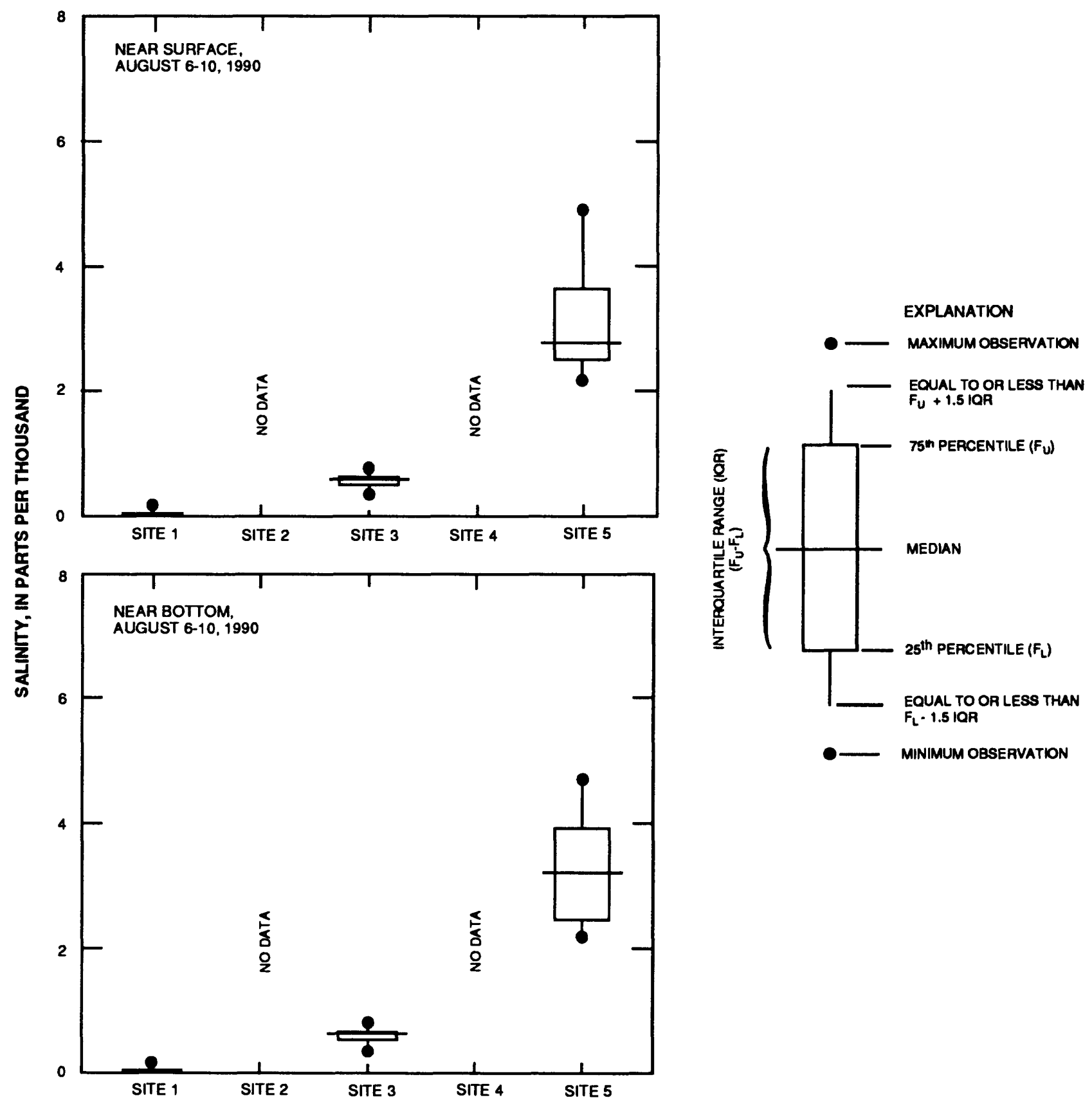

Figure 18. Salinity, near surface and near bottom, at sites 1, 3, and 5 for late summer conditions, August 6-10, 1990. 


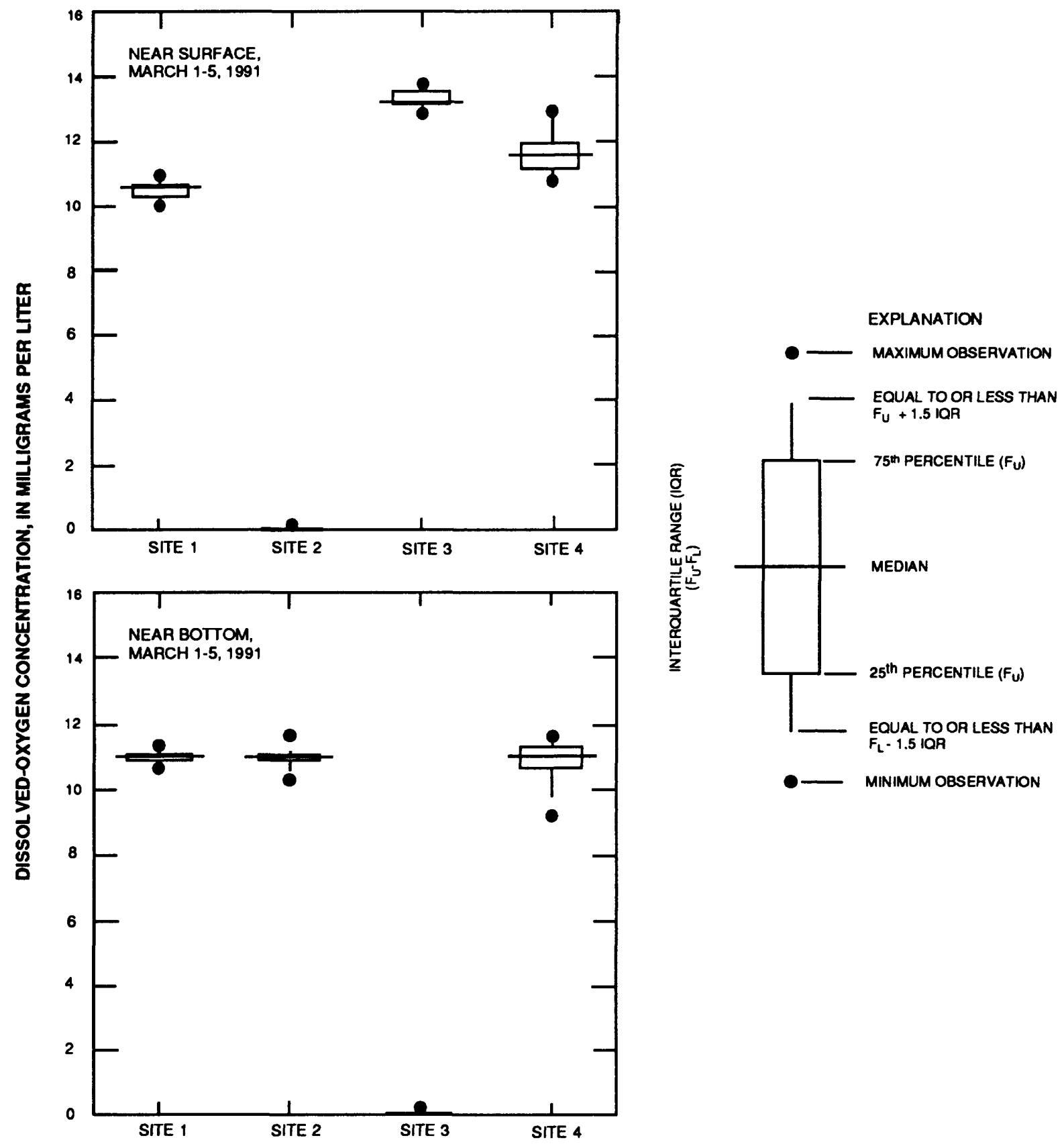

Figure 19. Dissolved-oxygen concentrations, near surface and near bottom, at sites 1-4 for early spring conditions, March 1-5, 1991. 


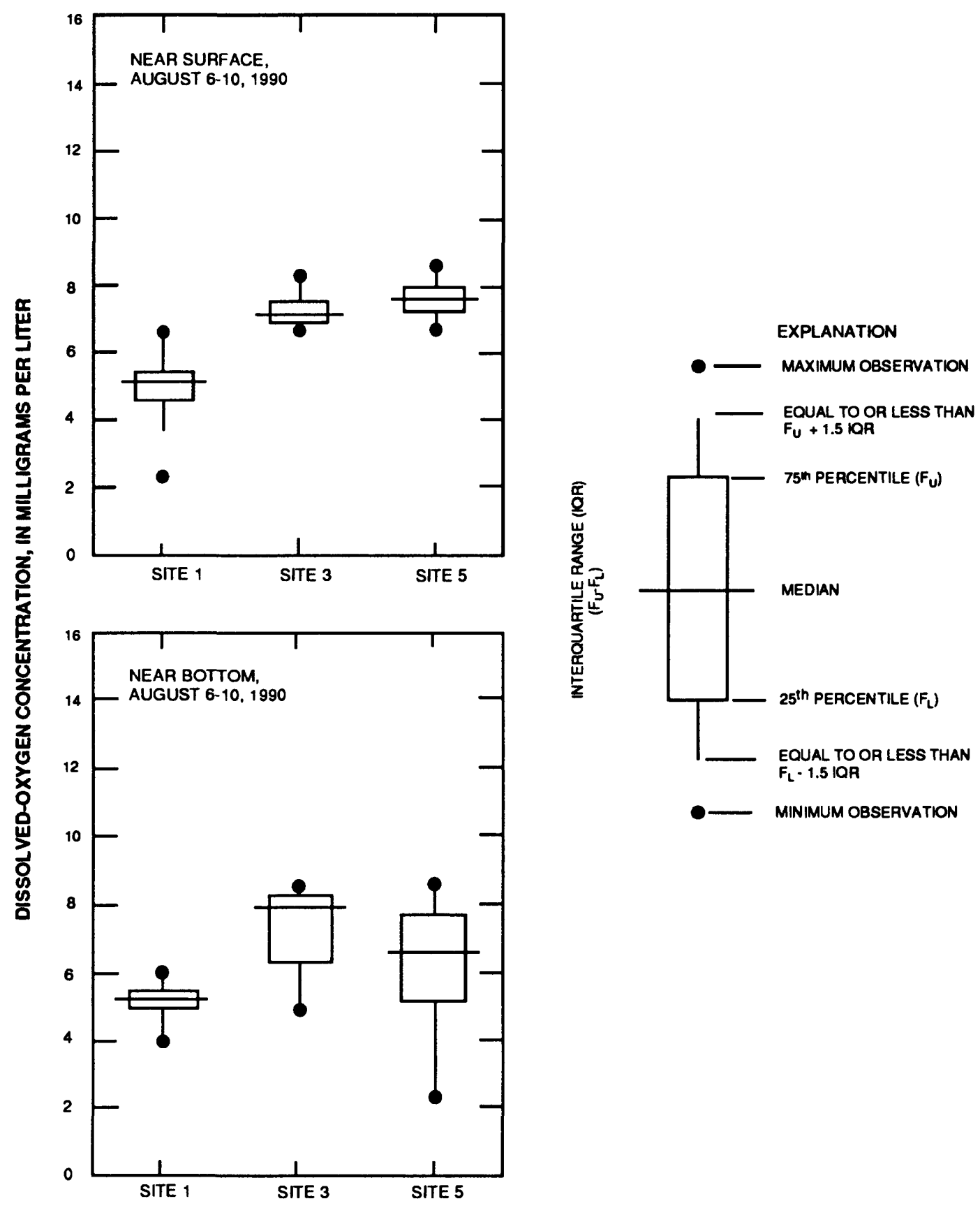

Figure 20. Dissolved-oxygen concentrations, near surface and near bottom, at sites 1,3, and 5 for late summer conditions, August 6-10, 1990. 

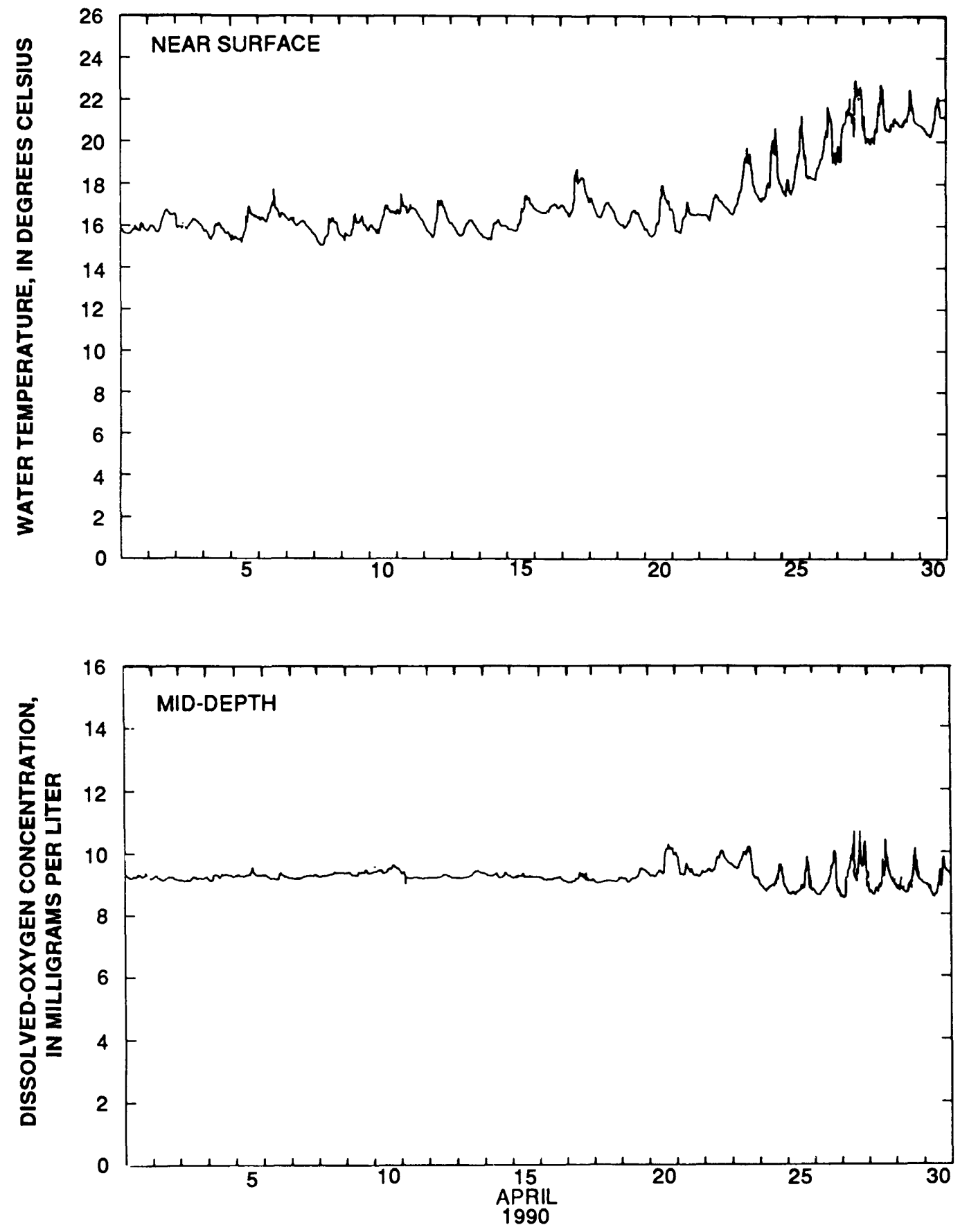

Figure 21. Continuous records of near-surface temperature and dissolved-oxygen concentration at mid-depth; site 3, April 1990. 
Suitable habitat for striped bass seems to include water temperatures less than $25^{\circ} \mathrm{C}$ and dissolved-oxygen concentrations greater than $5 \mathrm{mg} / \mathrm{L}$ (Coutant, 1985). As indicated in table 8, near-surface water temperatures in western (site 1), central (site 3), and eastern (site 5) Albemarle Sound exceeded $25^{\circ} \mathrm{C}$ for most of July and August 1990, and for much of June and September 1990. Field measurements of vertical profiles of water temperature indicated that there typically was no difference between near-surface and near-bottom water temperature. On one occasion (August 14, 1990), a top-to-bottom difference in temperature of $2.5^{\circ} \mathrm{C}$ was observed at site 1 ; even so, the near-bottom water temperature exceeded $25^{\circ} \mathrm{C}$. Dissolved-oxygen concentrations of less than $5 \mathrm{mg} / \mathrm{L}$ also occurred during the summer of 1990, with the most frequent occurrences being at the western end of the sound.

Table 8.--Number of days with maximum water temperature exceeding $25^{\circ} \mathrm{C}$ or minimum dissolved-oxygen concentration less than 5 milligrams per liter at sites 1, 3, and 5, April to September 1990

[T $>25$, maximum temperature greater than $25^{\circ} \mathrm{C} ; \mathrm{DO}<5$, minimum dissolvedoxygen concentration less than 5 milligrams per liter]

\begin{tabular}{|c|c|c|c|c|c|c|c|c|c|}
\hline \multirow[b]{2}{*}{ Month } & \multicolumn{3}{|c|}{ Site 1} & \multicolumn{3}{|c|}{ Site 2} & \multicolumn{3}{|c|}{ Site 3} \\
\hline & $\begin{array}{c}\text { Days } \\
\text { of } \\
\text { record }\end{array}$ & $\begin{array}{l}\text { Days } \\
\text { with } \\
\mathrm{T}>25\end{array}$ & $\begin{array}{c}\text { Days } \\
\text { with } \\
\text { DO }<5\end{array}$ & $\begin{array}{l}\text { Days } \\
\text { of } \\
\text { record }\end{array}$ & $\begin{array}{l}\text { Days } \\
\text { with } \\
\mathrm{T}>25\end{array}$ & $\begin{array}{c}\text { Days } \\
\text { with } \\
\text { DO }<5\end{array}$ & $\begin{array}{l}\text { Days } \\
\text { of } \\
\text { record }\end{array}$ & $\begin{array}{l}\text { Days } \\
\text { with } \\
\mathrm{T}>25\end{array}$ & $\begin{array}{c}\text { Days } \\
\text { with } \\
\text { DO }<5\end{array}$ \\
\hline Apr. & 28 & 2 & 0 & 28 & 0 & 0 & 28 & 0 & 0 \\
\hline May & 25 & 0 & 0 & 21 & 0 & 0 & 29 & 0 & 0 \\
\hline June & 18 & 14 & 0 & 5 & 0 & 0 & 27 & 18 & 3 \\
\hline July & 29 & 29 & 6 & 24 & 24 & 4 & 28 & 28 & 3 \\
\hline Aug. & 15 & 15 & 13 & 31 & 31 & 1 & 31 & 31 & 7 \\
\hline Sept. & 29 & 18 & 7 & 30 & 17 & 0 & 28 & 15 & 0 \\
\hline
\end{tabular}

\section{Plans For Completion of Monitoring}

Monitoring is scheduled to continue at least until October 1992 to meet the objectives of this investigation, as well as to provide information required by the Albemarle-Pamlico. Estuarine Study. The continued monitoring for the development of a long-term data base on salinity, temperature, and dissolved-oxygen concentrations in Albemarle Sound should provide information needed to detect trends, to characterize conditions during key hydrologic, water-quality, and biological events, and to provide basic information on estuarine water-quality processes.

When the monitoring is completed, plans for analysis of the data include the determination of the frequency, magnitude, and duration of density stratification from salinity and temperature records for each station. As a part of the data analysis, seasonality and spatial patterns in salinity distributions will be identified. The frequency and duration of the occurrence of low dissolved-oxygen concentrations (less than $5 \mathrm{mg} / \mathrm{L}$ and less than 2 
$\mathrm{mg} / \mathrm{L}$ ) will be determined for each station. The relation of low dissolved-oxygen concentrations to density stratification will be identified, and seasonal and spatial patterns will be characterized. As described in the following section, results from the hydrodynamic model of Albemarle Sound also will be used to assist in the interpretation of the waterquality data.

The data from the continuous water-quality monitors will be used in several ongoing investigations. Temperature and dissolved-oxygen data will be available for fish population modeling. The spatial patterns, duration, and frequency of high temperatures and low dissolved-oxygen concentrations for monitored periods can be used to assist in identifying possible Albemarle Sound water-quality effects on adult and subadult striped bass. Continuous information on salinity, temperature, and dissolved oxygen also will be available to supplement more detailed, but less frequent, sampling in western Albemarle Sound.

The hydrologic and water-quality data base for the rivers of North Carolina extends back more than 50 years at many locations, including the Roanoke River at Roanoke Rapids. Long-term records of water-quality information collected at regular intervals, however, are rare for most of the State's estuarine waters, as it is for much of the Nation's estuarine resources. An investment in estuarine water-quality data collection and analysis may prove just as valuable as similar historical and ongoing riverine efforts.

\section{HYDRODYNAMICS OF ALBEMARLE SOUND}

Flows and circulation in Albemarle Sound are governed by complex interactions among riverine inflows, ocean tides, wind, density gradients, and bathymetry. Flows in the sound vary both spatially and temporally. To study the flows and circulation patterns in the sound, a hydrodynamic model of the area is being implemented, calibrated, and validated as part of this investigation. A hydrodynamic model can be used to quantify bulk flow characteristics, circulation patterns, and transport of dissolved materials in the sound.

Circulation patterns simulated by the model may provide an indication of the distribution of phytoplankton, zooplankton, and striped bass larval fish within Albemarle Sound under various inflow conditions. Moreover, the effects of changes in bathymetry on circulation and transport patterns may be quantified. This section of the report describes the progress made on the modeling effort during the initial phase of the investigation and the plans for completion of the modeling effort.

\section{Hydrodynamic Model Area}

The area that is being modeled as part of this investigation includes essentially all of Albemarle Sound (fig. 16). Boundaries of the hydrodynamic model are (1) the mouth of the Roanoke River distributary (sites 11 and 12), (2) the mouth of the Chowan River (site 13), (3) Perquimans River at site 14, (4) the mouth of Little River, (5) Pasquotank River at site 15, (6) the mouth of North River, (7) the mouth of Currituck Sound (site 16), (8) Roanoke Sound at site 17, (9) Croatan Sound at site 18, (10) the mouth of Alligator River (site 19), and (11) the mouth of Scuppernong River. 


\section{Approach}

Although all natural flows are inherently three dimensional in space, many engineering and management problems can be solved using a well-formulated, tested, and properly calibrated two-dimensional model. Most of the primary biological and waterquality management issues in Albemarle Sound can be addressed adequately with a spatially detailed, vertically integrated two-dimensional model. Moreover, threedimensional models generate very large quantities of information to be processed and assimilated, and their computational requirements are high. Because Albemarle Sound is seldom stratified and because the water-quality and biological components of companion studies do not require full vertical resolution, a two-dimensional representation of Albemarle Sound was considered adequate for addressing present biological and waterquality issues.

A two-dimensional, vertically integrated model is being applied to Albemarle Sound. The model was first developed for applications in Jamaica Bay, N.Y. (Leendertse and Gritton, 1971). Since that time, the model has undergone numerous revisions and updates. It is now probably the most widely used, best documented model of vertically integrated hydrodynamics.

The three-dimensional equations of motion are reduced to a set of twodimensional equations by assuming that vertical accelerations are negligibly small and by integrating the equations over the depth of flow. The resulting equations are nonlinear and timedependent, and they retain coupling of motion and transport equations (that is, time-varying spatial density gradients are included in the equations of motion). Because the nonlinear advective and bottom stress terms are retained, residual circulation may be computed. The model has been used in many applications. The model was used to investigate flooding and drying of tidal flats in Port Royal Sound, S.C. (Schaffranek and Baltzer, 1988) and in the design of the Dutch Delta Works (Leendertse and others, 1981). A variation of the model also has been applied to San Francisco Bay (Cheng and Smith, 1985).

As with the Roanoke River flow model, data are required to calibrate, validate, and operate the Albemarle Sound hydrodynamic model. In general, any model application requires information at water-surface, estuary-bottom, and lateral boundaries. Measurements of velocities, water-surface elevations, and salinity concentrations also are required at key locations within the modeled region to calibrate and validate the model to observed data.

\section{Data-Collection}

The data-collection network for the hydrodynamic model includes the continuously monitored water-quality sites (sites 1-10) listed in table 6, and the continuously monitored water-level and wind data-collection sites (sites 11-21) listed in table 9. The locations of these 11 sites are shown in figure 16. (Sites 11 and 12 also were used in the Roanoke River model study, table 2 and figure 2 ). 
Table 9.--Water-level and wind data-collection network for Albemarle Sound hydrodynamic modeling

[USGS, U.S. Geological Survey; --, not applicable]

\begin{tabular}{|c|c|c|c|c|c|}
\hline $\begin{array}{c}\text { Site } \\
\text { number } \\
\text { (fig. 16) }\end{array}$ & $\begin{array}{l}\text { USGS } \\
\text { station } \\
\text { number }\end{array}$ & Location & Latitude & Longitude & $\begin{array}{l}\text { Data } \\
\text { type }\end{array}$ \\
\hline 11 & 0208114360 & $\begin{array}{r}\text { Cashie River at State } \\
\text { Highway } 45 \text { bridge }\end{array}$ & $35^{\circ} 55^{\prime} 24^{\prime \prime}$ & $76^{\circ} 44^{\prime} 01^{\prime \prime}$ & water level \\
\hline 12 & 0208114150 & $\begin{array}{l}\text { Roanoke River at State } \\
\text { Highway } 45 \text { bridge }\end{array}$ & $35^{\circ} 54^{\prime} 53^{\prime \prime}$ & $76^{\circ} 43^{\prime} 23^{\prime \prime}$ & water level \\
\hline 13 & 0205365200 & $\begin{array}{c}\text { Chowan River at U.S. } \\
\text { Highway } 17 \text { bridge }\end{array}$ & $36^{\circ} 02^{\prime} 52^{\prime \prime}$ & $76^{\circ} 41^{\prime} 42^{\prime \prime}$ & $\begin{array}{l}\text { water level, } \\
\text { wind }\end{array}$ \\
\hline 14 & 02043892 & $\begin{array}{l}\text { Perquimans River at } \\
\text { Hertford }\end{array}$ & $36^{\circ} 11^{\prime} 40^{\prime \prime}$ & $76^{\circ} 28^{\prime} 00^{\prime \prime}$ & water level \\
\hline 15 & 02043682 & $\begin{array}{l}\text { Pasquotank River at } \\
\text { Elizabeth City }\end{array}$ & $36^{\circ} 18^{\prime} 00^{\prime \prime}$ & $76^{\circ} 13^{\prime} 00^{\prime \prime}$ & water level \\
\hline 16 & 0204295510 & $\begin{array}{l}\text { Currituck Sound at } \\
\text { Point Harbor }\end{array}$ & $36^{\circ} 04^{\prime} 46^{\prime \prime}$ & $75^{\circ} 47^{\prime} 24^{\prime \prime}$ & water level \\
\hline 17 & 0208117990 & $\begin{array}{l}\text { Roanoke Sound at U.S. } \\
\text { Highway } 64-264 \text { bridge }\end{array}$ & $35^{\circ} 53^{\prime} 55^{\prime \prime}$ & $75^{\circ} 36^{\prime} 56^{\prime \prime}$ & water level \\
\hline 18 & 0208117948 & $\begin{array}{l}\text { Croatan Sound near } \\
\text { Manns Harbor }\end{array}$ & $35^{\circ} 54^{\prime} 24^{\prime \prime}$ & $75^{\circ} 46^{\prime} 07^{\prime \prime}$ & water level \\
\hline 19 & 0208117839 & $\begin{array}{l}\text { Alligator River at U.S. } \\
\text { Highway } 64 \text { bridge }\end{array}$ & $35^{\circ} 54^{\prime} 16^{\prime \prime}$ & $76^{\circ} 01^{\prime} 39^{\prime \prime}$ & water level \\
\hline 20 & 02053606050 & $\begin{array}{c}\text { Chowan River at } \\
\text { Cannon Ferry }\end{array}$ & $36^{\circ} 16^{\prime} 16^{\prime \prime}$ & $76^{\circ} 40^{\prime} 22^{\prime \prime}$ & water level \\
\hline 21 & -- & Headquarters Island & $35^{\circ} 51^{\prime} 51^{\prime \prime}$ & $75^{\circ} 36^{\prime} 22^{\prime \prime}$ & wind \\
\hline
\end{tabular}




\section{Water Level}

Water-level recorders have been installed at Chowan River at U.S. Highway 17 bridge, Perquimans River at Hertford, Pasquotank River at Elizabeth City, Currituck Sound at Point Harbor, Roanoke Sound at U.S. Highway 64-264 bridge, Croatan Sound near Manns Harbor, and Alligator River at U.S. Highway 64 bridge (table 9). Water-level at these sites and data from the two gages located in the Roanoke River distributary (Roanoke River at State Highway 45 bridge and Cashie River at State Highway 45 bridge) (fig. 2) will be used in model calibration and verification. Data are recorded at 15-minute intervals. Data from an existing U.S. Army Corps of Engineers' gage on the Scuppernong River at Columbia, N.C., also will be used.

Modeling requires that water levels be referenced to a common datum. Hence, levels have been run from the nearest benchmark to each gage site.

\section{Inflow and Outflow}

For long-term simulations, there may be a need to specify diffuse inputs to (rainfall and local inflows) and losses from (evaporation) the sound. (Inflow and outflow across model boundaries at tributary rivers is determined by the model.) Rainfall on Albemarle Sound accounts for about 20 percent of the annual freshwater inflow to the sound, and evaporation represents a loss equal to about 15 percent of the annual freshwater inflow (Giese and others, 1985). Precipitation records are available from the National Oceanic and Atmospheric Administration (NOAA) for measuring sites in Elizabeth City, Edenton, Murfreesboro, Lewiston, Williamston, Plymouth, Columbia, and Manteo, N.C. Evaporation records are available from measurement sites at Aurora, N.C. (about 43 mi southeast of Williamston), and Holland, Va. (about 61 mi northeast of Williamston). These data will be obtained as needed and used in the hydrodynamic model of the sound.

According to Giese and others (1985), the local inflows to Albemarle Sound on an annual basis are less than the volume of rainfall that falls on the open waters of the sound. Consequently, precise determination of local inflows, which would be quite difficult and expensive, is not required to accurately model hydrodynamics and transport in Albemarle Sound. Daily average local inflows to the sound will be estimated from nearby stream gages at Ahoskie Creek at Ahoskie, Cashie River at Windsor, Chinkapin Creek tributary near Harrellsville, Potecasi Creek near Union, and Van Swamp near Hoke (fig.1).

\section{Wind}

Continuously-recording wind anemometers have been installed on the Chowan River U.S. Highway 17 bridge and on Headquarters Island in Roanoke Sound. The anemometers record average wind speed and direction at 30-minute intervals. Sensors were placed the standard height of $33 \mathrm{ft}$ above the water.

\section{Salinity and Temperature}

Continuous records of salinity and temperature are required to properly model Albemarle Sound hydrodynamics because flows are generated in response to the pressure fields that result from longitudinal and lateral density gradients. Temperature and salinity 
data are required at boundaries for model operation and within the sound for model validation and calibration.

Water quality is being monitored continuously at 10 locations in and around Albemarle Sound (fig. 16; table 6). Boundary data are provided by monitors located at sites 1, 2, 5, 9, and 10 (fig. 16). Data collected at sites 3,4 , and 8 within the model area will help define spatial variation in water-quality data for model calibration and validation.

\section{Velocity}

Because the hydrodynamic model calculates water levels, salinities, and velocities in the interior of Albemarle Sound, the model should be calibrated to a time sequence of these types of data. Consequently, plans are to collect velocity data in Albemarle Sound using a recording Acoustic-Doppler Current Profiler (ADCP). The ADCP is a state-of-the-art, boatmounted velocity meter that can record velocities while the boat is underway. Recent improvements in ADCP technology allow the instrument to be used in shallow-water environments such as Albemarle Sound.

The ADCP continuously collects velocity data as the boat on which the instrument is mounted traverses the sound. Vertical profiles of horizontal velocity vectors are recorded at vertical increments of 10 centimeters over the full depth of flow, and at horizontal intervals of about $100 \mathrm{ft}$, depending on the boat speed. Data are transferred directly to an on-board computer where the data are processed and displayed. Compared to previously available methods for measuring estuarine velocity, the ADCP allows large quantities of high-quality, spatially detailed velocity data to be collected relatively quickly.

\section{Bathymetry}

Albemarle Sound bathymetric data needed for model development and calibration were obtained from the NOAA. Topography and hydrography of the region around the sound were digitized and placed in a GIS. These data were used to generate the numerical grid for the model, which is discussed in more detail in the section on Computational Grid Development.

\section{Preliminary Analyses of Albemarle Sound Water Levels}

Most of the efforts on the Albemarle Sound hydrodynamic modeling during the initial phase of this investigation have focused on development of the computational grid and on the network of salinity, temperature, and dissolved-oxygen monitors. Consequently, for this interim report, fewer data were available for Albemarle Sound hydrodynamic analysis than for the analysis of flow in the Roanoke River.

Data are being collected and analyzed to characterize the hydrology of Albemarle Sound as well as to calibrate, validate, and operate the model. Daily and seasonal waterlevel and salinity variations are being determined for each station. Water-level and salinity variations and interrelations among these parameters and wind also are being characterized using time-series and harmonic-analysis techniques. 
Records of water level measured simultaneously on the Chowan River at the U.S. Highway 17 bridge and on the Roanoke River at the State Highway 45 bridge indicate that the Albemarle Sound water surface slopes toward the mouth of the Roanoke River at times. During October and December 1990, water levels were higher at the Chowan River gage than at the Roanoke River gage about 80 percent of the time. Consequently, there may be some movement of Chowan River water into the mouth of the Roanoke River. Circulation modeling should provide more information on the movement and exchange of water in the western part of Albemarle Sound.

Tides at the mouth of the Roanoke River are well correlated with tides in Croatan Sound (fig. 22). Even during periods of falling water levels in Albemarle Sound, the tidal signal at Croatan Sound is transmitted upstream to the mouth of the Roanoke River (fig. 22, February 1-7, 1991).

There is about a 9-hour lag between the time of high tide in Croatan Sound and high tide at the mouth of the Roanoke River, but the tidal amplitude at the mouth of the Roanoke River generally is about the same as that in Croatan Sound. From December 1990 through March 1991, the mean daily water-level ranges in Croatan Sound and at the mouth of the Roanoke River were identical at $0.48 \mathrm{ft}$. However, during April 1991, when flows at the mouth of the river probably were high (provisional data for Roanoke Rapids shows flows in excess of $10,000 \mathrm{ft}^{3} / \mathrm{s}$ for most of April), the mean daily water-level range in Croatan Sound was $0.56 \mathrm{ft}$ compared with $0.39 \mathrm{ft}$ at the mouth of the Roanoke River.

More extensive analyses of these water-level data are underway to identify seasonal and spatial trends and to determine the relation between water-level variations and forcing mechanisms. Use of these data with the hydrodynamic model may provide a better understanding of circulation in Albemarle Sound.

\section{Computational Grid Development}

Computational grid development can be one of the more difficult aspects of model creation. Display of computed water-surface elevation contours, lines of equal constituent concentrations, and velocity vectors often requires the development of customized graphics routines. Moreover, hydrodynamic model results from this investigation need to be linked with water-quality, biological, and land-use analyses.

Hydrodynamic modeling relates spatially varying forces and bathymetry to spatially varying water-particle accelerations. Hence, the use of an automated technique for grid development and spatial analysis is an appropriate strategy for improving the efficiency and effectiveness of hydrodynamic modeling. The automated technique for handling spatial data used in this study is the geographic information system (GIS), which provides for efficient data organization, information display, further analyses of model results, and linkages with other types of spatial data. According to Clark (1986), a GIS contains the following elements: (1) a large body of data having spatial properties; (2) numerical expressions of relations among the data; (3) a common data structure; and (4) the ability to perform automated data capture, storage, retrieval, analysis, and display. 


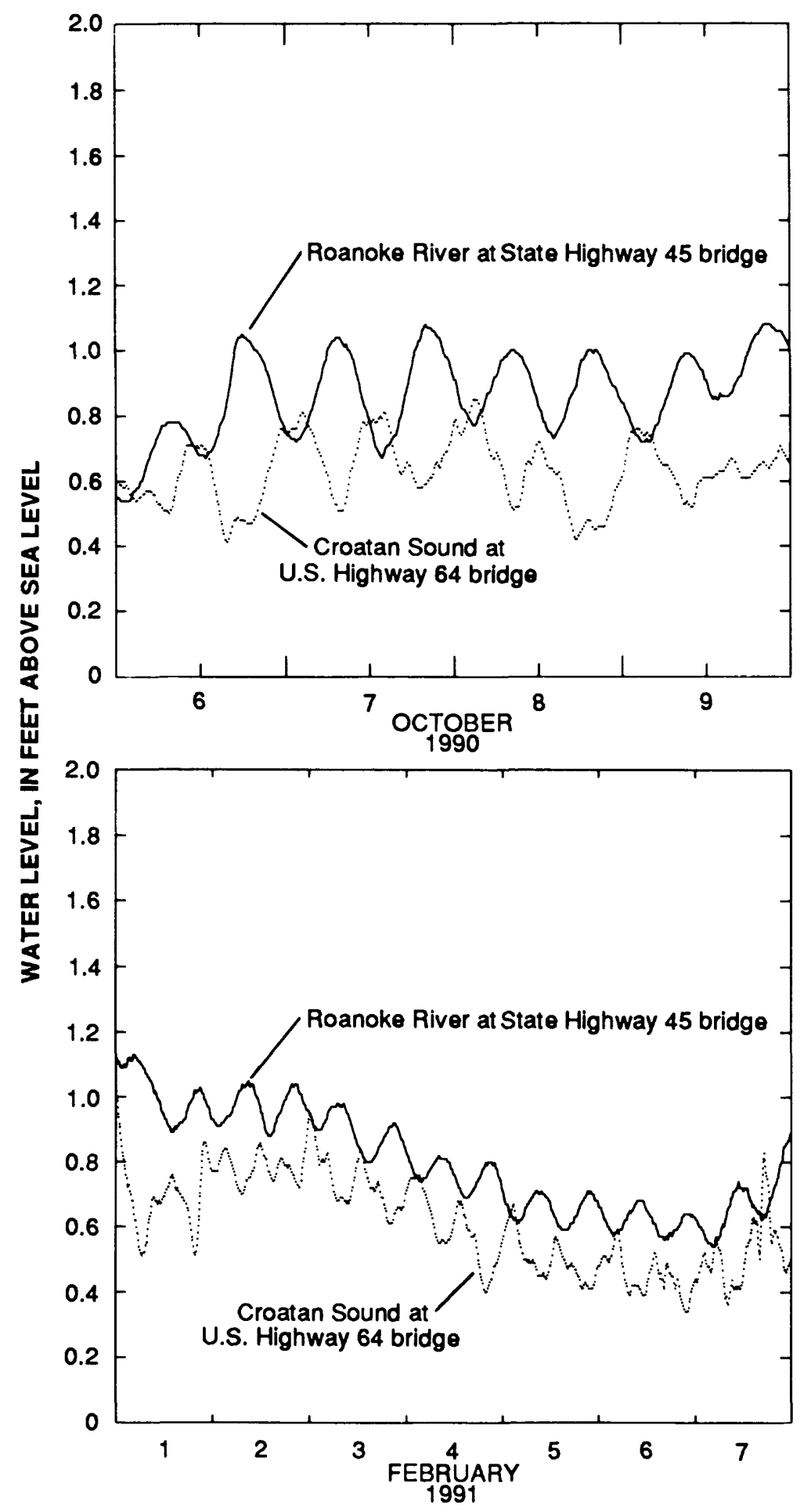

Figure 22. Water levels in Croatan Sound and the Roanoke River at State Highway 45 and U.S. Highway 64 bridges for October 6-9, 1990, and February 1-7, 1991. 
Information from USGS 7.5-minute topographic maps (scale 1:24,000), National Ocean Service (NOS) Hydrographic Data Base digital files, and NOS navigation charts (scale $1: 80,000)$ was used to develop the computational grid for the Albemarle Sound hydrodynamic model. Data from an approximately $1,980 \mathrm{mi}^{2}$ area were entered into the GIS.

All topographic land-surface elevation contours less than $15 \mathrm{ft}$ were digitized from the 7.5-minute maps. Because of the small topographic relief around Albemarle Sound, all spot elevations shown on the maps also were entered into the GIS as part of the elevation coverage. Digital information from the NOS Hydrographic Data Base for the central part of the sound provided detailed bathymetric data at more than 100,000 points. Data stored in GIS for those points included latitude, longitude, depth, and a bottom descriptor. Spot bathymetric elevations from NOS navigation charts were digitized to complete the data base. NOS data were converted from depth below mean low water to elevation relative to sea level, which was the datum for the 7.5 minute-maps.

Elevation data from the three sources were combined in the GIS to provide a data layer. Some editing of data was required to ensure the continuity of elevation contours at the boundaries of adjacent maps. The vertexes along the contours were converted to points, and an automated editing routine within the GIS was used to reduce and generalize the data base so that the minimum distance between observation points was 20 meters.

A model of the elevation surface of the study area was created by using GIS-based software and the elevation data base. This model was created with a structure known as a Triangular Irregular Network (TIN). Within this TIN, the vertexes of each triangle are known points with known elevation. The slope and aspect of each triangle represent the slope and aspect of the land surface bounded by the triangle. The TIN was especially useful in this application because a representative surface model could be generated from irregularly spaced data with a minimum amount of data storage and handling.

Because elevations at all locations on the surface can be interpolated from the TIN, the surface model can be used to generate elevation contours at any desired interval. This capability is being used, for example, to produce detailed elevation contour maps so that the relation between storage and water elevation in the broad Roanoke River flood plain can be determined.

The final step in the development of the computational grid was to generate a lattice, representing the model grid, to overlay the surface model. Axes of the lattice were oriented in the desired directions, and a grid consisting of 200 meter square cells was used. The lattice, with elevations and coordinates at lattice vertexes interpolated from the surface model, then became the computational grid for the hydrodynamic model. The model grid of land surface elevations for the western part of Albemarle Sound (excluding the rivers) is shown in figure 23. The lattice also was stored in the GIS for later use in the display of model results. 


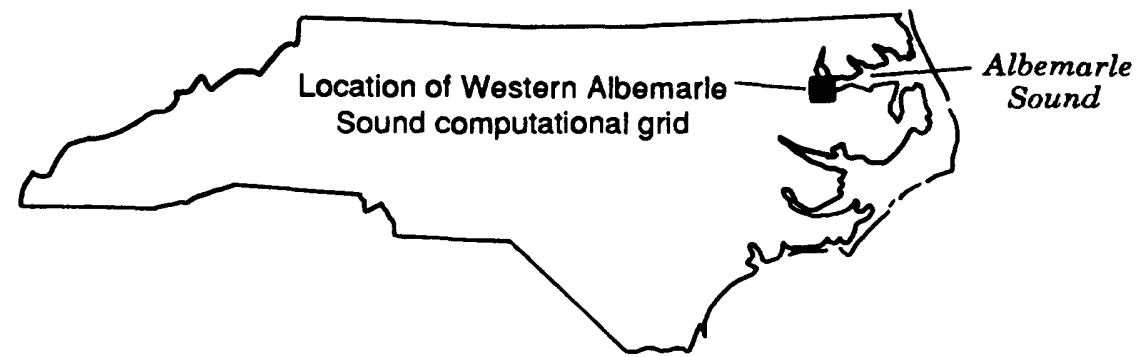

MAP OF NORTH CAROLINA SHOWING LOCATION OF STUDY AREA

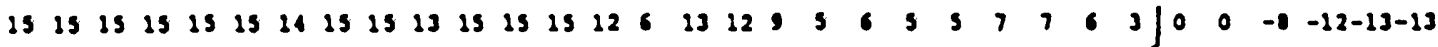

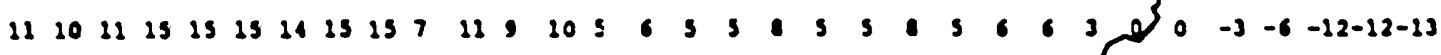

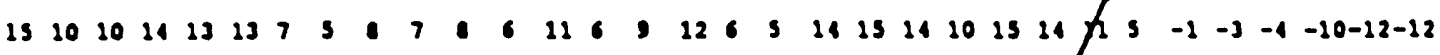

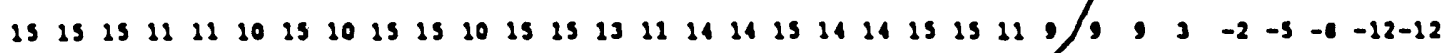

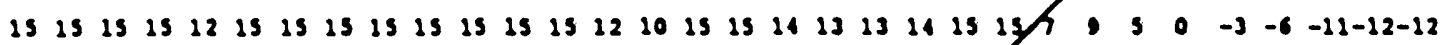

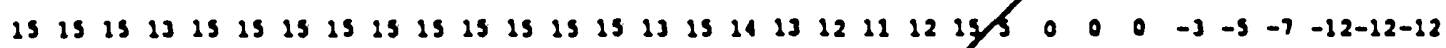
15 is 15 is 15 is 15 is 15 is 15 is 15 is 15 is $1513121015 / 1-2-6-6-6-7-12-12-12-12-12$

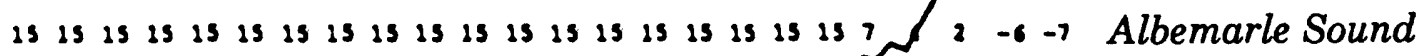

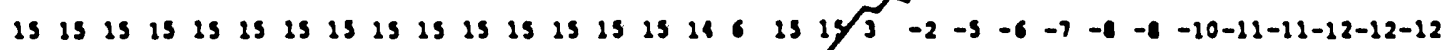

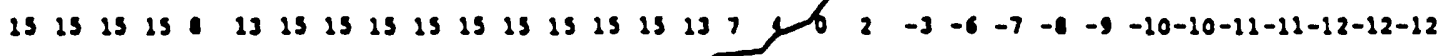

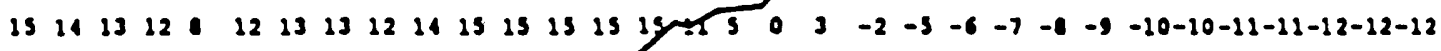
1513101215112510,10 , $13,07-2-3-4-4-5-6-6-6-7-8-9-10-10-11-11-12-12-12$

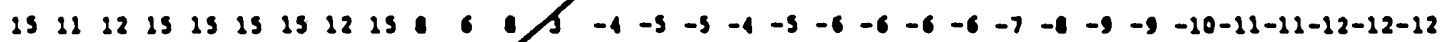

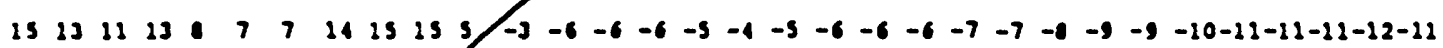

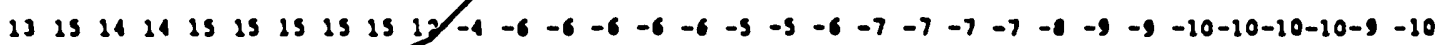
1514 is 15 is 15 is 1515

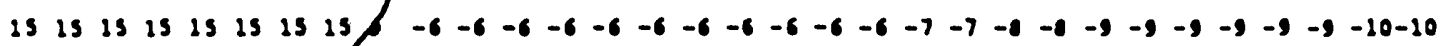

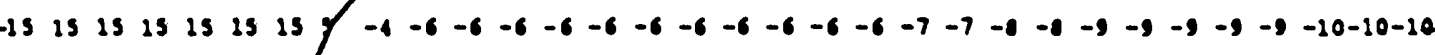

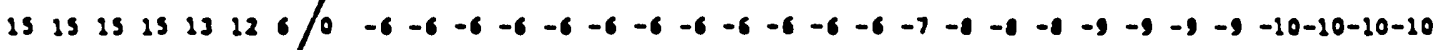

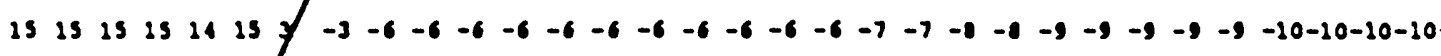

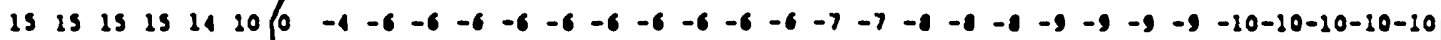

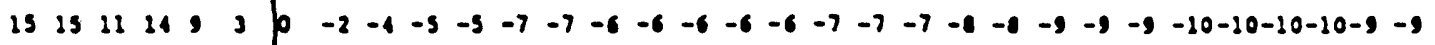

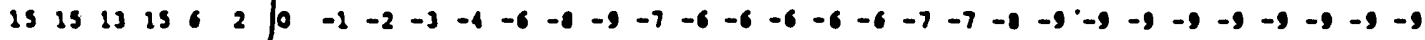

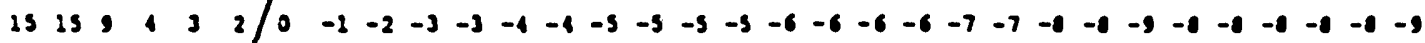

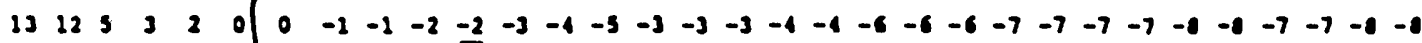

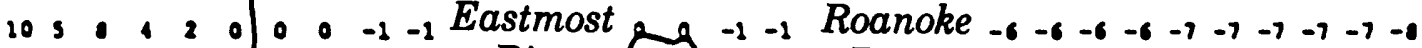

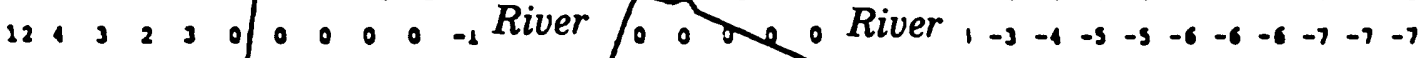

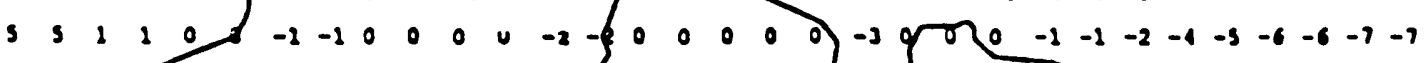
$35056^{\prime} 15^{\prime \prime}$ 0
0

Figure 23. Western Albemarle Sound computational grid of land-surface elevations. 


\section{Plans for Completion of Hydrodynamic Model}

The plans for the completion and application of the model in future phases of this investigation include (1) creation of postprocessing routines using the GIS; (2) model calibration, model validation, and sensitivity testing; and (3) model application.

Any combination of seabed elevation, water-surface elevation, salinity, and velocitymagnitude contours can be produced by the GIS for postprocessing model results. Although other contouring software packages are widely available, the ability to select from combinations of data layers (variable type, time, and computational layer for threedimensional models) gives the GIS added flexibility. Velocity vectors also can be displayed by the GIS by passing velocities in polar coordinates to the GIS and using the special-symbol plotting routine of the GIS.

Detailed analyses of model results can be enhanced by use of the GIS. Simple statistics, such as maximum, minimum, and mean values, can be computed for the data layers. Mean salinity within a region or at a transect can be determined easily. Automated selection and display of areas having designated combinations of hydrodynamic characteristics are also possible using the analytical capabilities of the GIS. For example, computational cells having a salinity greater than $3 \mathrm{ppt}$ and a depth greater than $10 \mathrm{ft}$ could be identified at a particular computational time step. Model calibration also can be facilitated by identifying numerical anomalies using the analytical capabilities of the GIS.

The planned calibration and validation of the hydrodynamic model will be accomplished in a manner somewhat analogous to that used for the Roanoke River model. The model will be calibrated using water-level, inflow, velocity, salinity, and wind data collected during an approximately 10 -day period. Observed and simulated water levels, salinities, and velocities will be compared, and model parameters will be adjusted as necessary. The model will then be validated using a separate set of water-level, inflow, velocity, salinity, and wind data.

The sensitivity of computed water-levels, salinities, and velocities to variations in computational time step, salinity boundary conditions, water-level boundary conditions, wind, and internal model parameters will be characterized. In some studies, results have indicated that model calibration is easier using upstream inflow rates rather than water levels as boundaries. As part of the analysis of model sensitivity to boundary conditions, results obtained by using water levels will be compared with results obtained by using modeled inflow rates as a boundary condition. Moreover, the effect of changes in the inflow boundary condition on circulation patterns will be determined.

After the model has been calibrated and validated, it is planned that it will be operated, using observed boundary data, for the period of about March 5, 1991 (the beginning of water-quality sampling in Albemarle Sound), to some time (corresponding to the transit time down the Roanoke) after the end of striped bass spawning in the Roanoke River. Modeling results and results of water-quality measurements and biological sampling can then be used to compare circulation patterns and the distribution of phytoplankton, zooplankton, and larvae in Albemarle Sound during the 1991 sampling period. These results also can be used to define the relation of circulation to water-quality characteristics and to 
the distribution of biological parameters to be characterized for the 1991 spawning season. Model results may also provide detailed information on water-level conditions and the salinity regime in Albemarle Sound during the sampling period.

Planned applications of the model in later phases of the study include the use of assumed boundary conditions to determine circulation patterns and salinity distribution in Albemarle Sound for Roanoke River inflows of about 2,500, 10,000, and 20,000 $\mathrm{ft}^{3} / \mathrm{s}$. Each inflow condition will be simulated with light winds, strong northerly winds, and strong southerly winds for a total of nine simulations. These results can quantify circulation in Albemarle Sound under various Roanoke River inflow regimes. If the biological data collected in 1991 indicate that circulation and distribution of biological parameters are strongly linked, then circulation patterns may be used to estimate the distribution of phytoplankton, zooplankton, and larvae under these inflow regimes.

Finally, for Roanoke River inflows of about 2,500 and $20,000 \mathrm{ft}^{3} / \mathrm{s}$, it is proposed that circulation in the western part of Albemarle Sound will be determined for historic bathymetric conditions. Results can be compared with simulated circulation under present bathymetric conditions to provide insight into possible changes in distribution of larval fish and food for the fish in the western part of Albemarle Sound as a result of changing bathymetry.

Analyses of data, two-dimensional modeling results, and the needs of other scientists and resource managers may indicate the need to investigate the flow structure in small regions of Albemarle Sound using a three-dimensional hydrodynamic model. The data collection for this investigation is sufficiently comprehensive to satisfy data requirements for two- or three-dimensional modeling. The three-dimensional model of Blumberg and Mellor (1987), which has been applied to estuaries and the coastal ocean and which is being used by the USGS at other locations, can be used if needed.

The Blumberg-Mellor model is one of the few three-dimensional models for which (1) the hydrodynamic and density (or salinity) fields are physically coupled, (2) a realistic turbulence closure scheme is incorporated, (3) the characteristics of the numerical solution scheme have been well documented and tested, and (4) there have been numerous applications in a variety of settings. In this model, the temperature and salinity fields are coupled to the hydrodynamics so that density circulation in the estuary may be represented. The model, which is configured for use on high-speed, cost-efficient, array-processing computers, allows the incorporation of realistic bathymetry within the finite-difference computational grid. Applications of the model have included the simulation of tides in Chesapeake Bay, coastal circulation near Long lsland, N.Y., and general circulation in the Middle and South Atlantic Bights and in the Gulf of Mexico (Blumberg and Mellor, 1987).

\section{SUMMARY}

A 3-year investigation was begun in 1990 to (1) develop a one-dimensional, unsteadyflow model for computing flows in the lower $67 \mathrm{mi}$ of the Roanoke River, (2) characterize water-quality conditions in Albemarle Sound, and (3) describe the circulation regime of Albemarle Sound. Data and results obtained during the first year of the study and plans for study completion are summarized in this report. 
Water levels in Albemarle Sound may affect flows in the Roanoke River as far upstream as $59 \mathrm{mi}$ from the mouth of the river. Water levels in the lower $20 \mathrm{mi}$ of the Roanoke fluctuate in response to water levels in Albemarle Sound even during periods of high river inflow. Moreover, the presence of higher water levels downstream relative to those upstream indicates that reverse flows likely occurred in the lower $20 \mathrm{mi}$ of the Roanoke River in October and December 1990.

A one-dimensional, unsteady-flow model has been constructed to compute flows in the Roanoke River between the State Highway 11-42 bridge (river mile 67.0) and Jamesville (river mile 19.4). The model currently is calibrated and validated for the reach of the Roanoke River between the State Highway 11-42 bridge and Williamston (river mile 36.6). For the calibrated model, simulated and observed water levels at Hamilton typically differed by less than 0.5 foot. The difference between observed and simulated depth of flow was less than 5 percent at high water levels. A comparison of simulated flows with 33 discharge measurements indicated that the simulated flows generally were within 10 percent of observed values. Actual flow measurements, which are used to develop stage-discharge relations, are considered to have an accuracy of about 5 percent. Hence, these flow simulations have nearly the accuracy of discharge values computed from stage-discharge relations at other sites.

Plans for completion of the modeling effort include expanding the model in increments to include the river reach between Williamston and Albemarle Sound. Plans also call for the testing of the sensitivity of model results to small changes in model parameters. Following calibration, validation, and testing of the expanded flow model, the model can be used to simulate flows in the Roanoke River for periods during which boundary data are available.

Near-surface and near-bottom specific conductance, near-surface water temperature, and near-surface, mid-depth, and near-bottom dissolved-oxygen concentrations are monitored at 15-minute intervals and at 10 locations in Albemarle Sound. At 5 of the 10 stations for which data are available, salinity values calculated from observed specific conductance ranged from essentially 0 to more than 9 parts per thousand, and the observed daily range (difference between daily maximum and minimum values) of salinity at each site generally was less than 1 part per thousand. The observed annual variation in water temperature was more than $30^{\circ} \mathrm{C}$; diurnal temperature fluctuations were about $1.3^{\circ} \mathrm{C}$. Dissolved-oxygen concentrations ranged from supersaturated to hypoxic conditions. The daily range in dissolved oxygen typically was larger during the summer months than during the rest of the year.

Monitoring is scheduled to continue at least until October 1992. The continued monitoring for the development of a long-term data base should provide information necessary to detect trends, characterize conditions during various flow conditions, and provide basic information on estuarine water-quality processes. Results from the Albemarle Sound hydrodynamic model may be used to assist in the interpretation of the water-quality data.

Tides at the mouth of the Roanoke River are well correlated with tides in Croatan Sound. Even during periods of falling water levels in Albemarle Sound, the tidal signal at Croatan Sound is transmitted upstream to the mouth of the Roanoke River. There is about a 
9-hour lag between the time of high tide in Croatan Sound and high tide at the mouth of the Roanoke River, but the observed tidal amplitude in Croatan Sound and at the mouth of the Roanoke was generally about 0.45 foot.

To investigate flows and circulation patterns in Albemarle Sound, a hydrodynamic model of the sound is being constructed, calibrated, and validated. The computational grid for the model has been developed using a geographic information system. Following model calibration and validation, plans call for application of the model to characterize circulation patterns and salinity distributions for various Roanoke River inflow regimes. Circulation patterns may be used to estimate the distribution of phytoplankton, zooplankton, and striped bass larvae in Albemarle Sound for different inflow regimes.

\section{REFERENCES CITED}

Arcement, G.J., Jr., 1988, Simulation of flow in the lower Calcasieu River from the saltwater barrier to Burton Landing near Moss Lake, Louisiana: U.S. Geological Survey Water-Resources Investigations Report 87-4087, 30 p.

Blumberg, A.F., and Mellor, G.L., 1987, A description of a three-dimensional coastal ocean circulation model, in Heaps, N.S., ed., Three-dimensional coastal ocean circulation models: Washington, D.C., American Geophysical Union, Coastal and Estuarine Sciences 4, p. 1-16.

Campbell Scientific, Inc., 1987, SM192/SM176 storage module preliminary instruction manual: Logan, Utah.

1988, CR10 measurement and control module operator's manual: Logan, Utah.

Carswell, W.J., Sanders, C.L., and Johnson, D.M., 1988, Freshwater supply potential of the Atlantic Intracoastal Waterway near Myrtle Beach, South Carolina: U.S. Geological Survey WaterResources Investigations Report 88-4066, 45 p.

Cheng, R.T., and Smith, L.H., 1985, Tidal hydraulics of San Francisco Bay and estuary, in Selenium and agricultural drainage--implications for San Francisco Bay and the California environment: Berkeley, California, Second Selenium Symposium, p. 131-151.

Clark, K., 1986, Recent advances in geographic information system research: Geo-Processing, v. 3, p. 1-15.

Copeland, B.J., ed., 1989, Albemarle/Pamlico Sound preliminary technical analysis of status and trends: Raleigh, Project No. 89-13A, Albemarle-Pamlico Estuarine Study, North Carolina Department of Environment, Health, and Natural Resources, 429 p.

Copeland, B.J., Hodson, R.G., Riggs, S.R., and Easley, J.E., 1983, The ecology of Albemarle Sound, North Carolina--an estuarine profile: Washington, D.C., Report No. FWS/OBS-83/01, U.S. Fish and Wildlife Service, Division of Biological Services, $68 \mathrm{p}$.

Coutant, C.C., 1985, Striped bass, temperature, and dissolved oxygen--a speculative hypothesis for environmental risk: Transactions of the American Fisheries Society, v. 114, p. 31-61. 
Ditmars, J.D., Adams, E.E., Bedford, K.W., and Ford, D.E., 1987, Performance evaluation of surface water transport and dispersion models: Bethesda, Md., Journal of Hydraulic Engineering, American Society of Civil Engineers, v. 113, n. 8, p. 961-980.

Ficken, J.H., and Scott, C.T., 1989, Operating manual for the U.S. Geological Survey minimonitor, 1988 edition, analog-voltage model: U.S. Geological Survey Open-File Report 89-403, 92 p.

Giese, G.L., Wilder, H.B., and Parker, G.G., Jr., 1985, Hydrology of major estuaries and sounds of North Carolina: U.S. Geological Survey Water-Supply Paper 2221, 108 p.

Gordon, A.B., and Katzenbach, M., 1983, Guidelines for use of water-quality monitors: U.S. Geological Survey Open-File Report 83-681, 94 p.

Hassler, W.W., Hill, N.L., and Brown, J.T., 1981, The status and abundance of striped bass, Morone saxatilis, in the Roanoke River and Albemarle Sound, North Carolina, 1956-1980: Morehead City, North Carolina Division of Marine Fisheries, Special Scientific Report 38, $156 \mathrm{p}$.

Holland, A.F., 1990, Near coastal program plan for 1990--estuaries: Narragansett, R.I., U.S. Environmental Protection Agency Report No. EPA/600/4-90/033.

Holman, R.E., 1988 (revised 1989), Albemarle-Pamlico Estuarine Study baseline water quality monitoring plan: Raleigh, North Carolina Department of Environment, Health, and Natural Resources Project No. 88-01/02, 32 p.

Kornegay, J.W., 1988, Preliminary assessment of summer habitat conditions for striped bass in Albemarle Sound: Raleigh, North Carolina Wildlife Resources Commission, Division of Boating and Inland Fisheries, Federal Aid in Fish Restoration Project F-22, 14 p.

Krug, W.R., Gebert, W.A., Graczyk, D.J., Stevens, D.L., Rochelle, B.P., and Church, M.P., 1990, Map of the mean annual runoff for the northeastern, southeastern, and mid-Atlantic United States, water years 1951-80: U.S. Geological Survey Water-Resources Investigations Report 88-4094, $11 \mathrm{p}$.

Leendertse, J.J., and Gritton, E.C., 1971, A water-quality simulation model for well mixed estuaries and coastal seas--volume III: Santa Monica, Ca., The RAND Corporation Report No. R-709-NYC.

Leendertse, J.J., Langerak, A., and de Ras, M.A.M., 1981, Two-dimensional tidal models for the Delta Works, in Fischer, H.B., ed., Transport models for inland and coastal waters-proceedings of a symposium on predictive ability: New York, Academic Press, p. 408-450.

Manooch, C.S., and Rulifson, R.A., eds., 1989, Roanoke River water flow committee report--a recommended water flow regime for the Roanoke River, North Carolina, to benefit anadromous striped bass and other below-dam resources and users: Beaufort, N.C., National Oceanic and Atmospheric Administration, National Marine Fisheries Service, Technical Memorandum NMFS-SEFC-216, 224 p. 
Martin Marietta Environmental Systems, 1987a, Chesapeake Bay mainstem monitoring program statistical and analytical support contract--final report, volume I: Annapolis, Md., Chesapeake Bay Program Report No. CBP/TRS 12/87, 49 p.

1987b, Chesapeake Bay mainstem monitoring program statistical and analytical support contract--final report, volume II: Annapolis, Md., Chesapeake Bay Program Report No. CBP/TRS 13/87, 535 p.

Miller, R.L., Bradford, W.L., and Peters, N.E., 1988, Specific conductance--theoretical considerations and application to analytical quality control: U.S. Geological Survey WaterSupply Paper 2311, 16 p.

National Academy of Sciences, 1977, Environmental monitoring--a report to the U.S. Environmental Protection Agency: Washington, D.C., 181 p.

National Research Council, 1990, Managing troubled waters--the role of marine environmental monitoring: Washington, D.C., National Academy Press, 125 p.

Noga, E.J., and Stanley, D.W., 1989, Determining the relationship between water quality and ulcerative mycosis in Atlantic menhaden, in Holman, R.E., ed., Project abstracts for the period 1989-1990: Raleigh, North Carolina Department of Environment, Health, and Natural Resources, Albemarle-Pamlico Estuarine Study Project No. 89/08, p. 30.

Pearce, J.B., and Despres-Patanjo, L., 1988, A review of monitoring strategies and assessments of estuarine pollution: Aquatic Toxicology, v. 11, p. 323-343.

Schraffranek, R.W., and Baltzer, R.A., 1988, A simulation technique for modeling flow on flood plains and in coastal wetlands, in Abt, S.R., and Gessler, J., eds., Hydraulic Engineering: New York, American Society of Civil Engineers, p. 732-739.

Schaffranek, R.W., Baltzer, R.A., and Goldberg, D.E., 1981, A model for simulation of flow in singular and interconnected channels: U.S. Geological Survey Techniques of WaterResources Investigations, book. 7, chap. C3, 110 p.

U.S. Department of the Interior and U.S. Department of Commerce, 1987, Emergency striped bass research study--report for 1986: Washington, D.C., 79 p.

Wells, J.T., 1989, A scoping study of the distribution, composition, and dynamics of water-column and bottom sediments--Albemarle-Pamlico estuarine system: Raleigh, North Carolina Department of Natural Resources and Community Development, Albemarle-Pamlico Estuarine Study Project No. 89-05, 39 p.

Wilder, H.B., Robison, T.M., and Lindskov, K.L., 1978, Water resources of northeast North Carolina: U.S. Geological Survey Water-Resources Investigations 77-81, 113 p. 
APPENDIX 
Daily mean values of specific conductance, salinity, water temperature, and dissolvedoxygen concentratons are presented for five sites in Albemarle Sound. Any significant changes that occur in these constituents at time scales of minutes to hours are not represented by the mean values. Mean values, however, do give a good indication of general conditions at a site so that a reasonable summary of the large quantity of data collected can be presented. At the bottom of each table is a graph of the data on that page.

Data are presented for October 1989 to April 1991. Specific conductance values are given in microsiemens per centimeter; salinity concentration is expressed as parts per thousand. Water temperature is given in degrees Celsius, and dissolved-oxygen concentrations are presented as milligrams per liter. No correction for the effects of salinity on dissolved oxygen has been made in the dissolved-oxygen data.

Tables 1-64. Daily mean values of:

1. Specific conductance, near surface, in water at site 1, Chowan

River near Edenhouse, October 1989 through September 1990

2. Specific conductance, near surface, in water at site 1 , Chowan River near Edenhouse, October 1990 through April 1991 70

3. Salinity concentration, near surface, in water at site 1 , Chowan River near Edenhouse, October 1989 through September 1990 71

4. Salinity concentration, near surface, in water at site 1 , Chowan River near Edenhouse, October 1990 through April 1991 72

5. Specific conductance, near bottom, in water at site 1, Chowan River near Edenhouse, October 1989 through September 1990

6. Specific conductance, near bottom, in water at site 1, Chowan River near Edenhouse, October 1990 through April 1991 74

7. Salinity concentration, near bottom, in water at site 1 , Chowan River near Edenhouse, October 1989 through September 1990

8. Salinity concentration, near bottom, in water at site 1 , Chowan River near Edenhouse, October 1990 through April 1991 76

9. Water temperature, near surface, in water at site 1 , Chowan River near Edenhouse, October 1989 through September 1990 
10. Water temperature, near surface, in water at site 1, Chowan River near Edenhouse, October 1990 through April 1991 78

11. Dissolved-oxygen concentration, near surface, in water at site 1 , Chowan River near Edenhouse, October 1989 through September 1990 79

12. Dissolved-oxygen concentration, near surface, in water at site 1 , Chowan River near Edenhouse, October 1990 through April 1991 80

13. Dissolved-oxygen concentration, mid-depth, in water at site 1 , Chowan River near Edenhouse, October 1989 through September 1990 81

14. Dissolved-oxygen concentration, mid-depth, in water at site 1 , Chowan River near Edenhouse, October 1990 through April 1991

15. Dissolved-oxygen concentration, near bottom, in water at site 1 , Chowan River near Edenhouse, October 1989 through September 1990

16. Dissolved-oxygen concentration, near bottom, in water at site 1 , Chowan River near Edenhouse, October 1990 through April 1991 84

17. Specific conductance, near surface, in water at site 2 , Roanoke River at light 1, November 1990 through May 1991 85

18. Salinity concentration, near surface, in water at site 2 , Roanoke River at light 1, November 1990 through May 1991 86

19. Specific conductance, near bottom, in water at site 2 , Roanoke River at light 1, November 1990 through May 1991 87

20. Salinity concentration, near bottom, in water at site 2 , Roanoke River at light 1, November 1990 through May 1991 88

21. Water temperature, near surface, in water at site 2 , Roanoke River at light 1, November 1990 through May 1991 89

22. Dissolved-oxygen concentration, near surface, in water at site 2 , Roanoke River at light 1, November 1990 through May 1991 90

23. Dissolved-oxygen concentration, mid-depth, in water at site 2, Roanoke River at light 1, November 1990 through May 1991 
24. Dissolved-oxygen concentration, near bottom, in water at site 2 , Roanoke River at light 1, November 1990 through May 1991

25. Specific conductance, near surface, in water at site 3 , Albemarle Sound at light 3, January through September 1990

26. Specific conductance, near surface, in water at site 3 , Albemarle Sound at light 3, October 1990 through May 1991 94

27. Salinity concentration, near surface, in water at site 3 , Albemarle Sound at light 3, January through September 1990 95

28. Salinity concentration, near surface, in water at site 3 , Albemarle

Sound at light 3, October 1990 through May 1991 96

29. Specific conductance, near bottom, in water at site 3, Albemarle Sound at light 3, January through September 1990

30. Specific conductance, near bottom, in water at site 3 , Albemarle Sound at light 3, October 1990 through May 1991 98

31. Salinity concentration, near bottom, in water at site 3, Albemarle Sound at light 3, January through September 1990

32. Salinity concentration, near bottom, in water at site 3 , Albemarle Sound at light 3, October 1990 through May 1991

33. Water temperature, near surface, in water at site 3 , Albemarle Sound at light 3, January through September 1990

34. Water temperature, near surface, in water at site 3, Albemarle Sound at light 3, October 1990 through May 1991 102

35. Dissolved-oxygen concentration, near surface, in water at site 3, Albemarle Sound at light 3, January through September 1990 103

36. Dissolved-oxygen concentration, near surface, in water at site 3 , Albemarle Sound at light 3, October 1990 through May 1991 104

37. Dissolved-oxygen concentration, mid-depth, in water at site 3, Albemarle Sound at light 3, January through September 1990 105

38. Dissolved-oxygen concentration, mid-depth, in water at site 3, Albemarle Sound at light 3, October 1990 through May 1991 106 
39. Dissolved-oxygen concentration, near bottom, in water at site 3 , Albemarle Sound at light 3, January through September 1990

40. Dissolved-oxygen concentration, near bottom, in water at site 3, Albemarle Sound at light 3, October 1990 through May 1991 108

41. Specific conductance, near surface, in water at site 4, Pasquotank River at light 1, January through May 1991

42. Salinity concentration, near surface, in water at site 4 , Pasquotank River at light 1, January through May 1991

43. Specific conductance, near bottom, in water at site 4, Pasquotank River at light 1, January through May 1991

44. Salinity concentration, near bottom, in water at site 4, Pasquotank River at light 1, January through May 1991

45. Water temperature, near surface, in water at site 4, Pasquotank River at light 1, January through May 1991

46. Dissolved-oxygen concentration, near surface, in water at site 4, Pasquotank River at light 1, January through May 1991 114

47. Dissolved-oxygen concentration, mid-depth, in water at site 4, Pasquotank River at light 1, January through May 1991 115

48. Dissolved-oxygen concentration, near bottom, in water at site 4, Pasquotank River at light 1, January through May 1991 116

49. Specific conductance, near surface, in water at site 5, Currituck Sound at U.S. Highway 158 bridge, January through September 1990

50. Specific conductance, near surface, in water at site 5, Currituck Sound at U.S. Highway 158 bridge, October 1990 through April 1991

51. Salinity concentration, near surface, in water at site 5 , Currituck Sound at U.S. Highway 158 bridge, January through September 1990

52. Salinity concentration, near surface, in water at site 5 , Currituck Sound at U.S. Highway 158 bridge, October 1990 through April 1991

53. Specific conductance, near bottom, in water at site 5, Currituck Sound at U.S. Highway 158 bridge, January through September 1990 
54. Specific conductance, near bottom, in water at site 5, Currituck Sound at U.S. Highway 158 bridge, October 1990 through April 1991

55. Salinity concentration, near bottom, in water at site 5 , Currituck Sound at U.S. Highway 158 bridge, January through September 1990

56. Salinity concentration, near bottom, in water at site 5 , Currituck Sound at U.S. Highway 158 bridge, October 1990 through April 1991

57. Water temperature, near surface, in water at site 5, Currituck Sound at U.S. Highway 158 bridge, January through September 1990

58. Water temperature, near surface, in water at site 5, Currituck Sound at U.S. Highway 158 bridge, October 1990 through April 1991

59. Dissolved-oxygen concentration, near surface, in water at site 5, Currituck Sound at U.S. Highway 158 bridge, January through September 1990

60. Dissolved-oxygen concentration, near surface, in water at site 5, Currituck Sound at U.S. Highway 158 bridge, October 1990 through April 1991 128

61. Dissolved-oxygen concentration, mid-depth, in water at site 5, Currituck Sound at U.S. Highway 158 bridge, January through September 1990

62. Dissolved-oxygen concentration, mid-depth, in water at site 5 , Currituck Sound at U.S. Highway 158 bridge, October 1990 through April 1991 130

63. Dissolved-oxygen concentration, near bottom, in water at site 5, Currituck Sound at U.S. Highway 158 bridge, January through September 1990

64. Dissolved-oxygen concentration, near bottom, in water at site 5, Currituck Sound at U.S. Highway 158 bridge, October 1990 through April 1991 
Table 1.--Daily mean values of specific conductance, near surface, in water at site 1, Chowan River near Edenhouse,

October 1989 through September 1990

STATION NUMBER AND NAME: 0205365200, Chowan River near Edenhouse

LATITUDE: $36^{\circ} 02^{\prime} 52^{\prime \prime}$ LONGITUDE: 76 $41^{\prime} 42^{\prime \prime}$ COUNTY: Bertie

PROBE LOCATION: 20 feet above bottom

[Specific conductance, microsiemens per centimeter at 25 degrees Celsius; ---, no data]

\begin{tabular}{|c|c|c|c|c|c|c|c|c|c|c|c|c|}
\hline Day & Oct. & Nov. & Dec. & Jan. & Feb. & Mar. & Apr. & May & June & July & Aug. & Sept. \\
\hline 1 & 107 & 89 & 98 & 153 & 77 & 143 & 141 & --- & 82 & 80 & --- & 77 \\
\hline 2 & --- & 92 & 99 & 155 & 75 & 140 & 142 & 83 & 82 & 81 & --. & 77 \\
\hline 3 & ..- & 92 & -- & 156 & 70 & 135 & 148 & 77 & 82 & 81 & 78 & 77 \\
\hline 4 & -.- & 93 & --- & 153 & 85 & 134 & 153 & 77 & 82 & 80 & --- & 78 \\
\hline 5 & --- & 92 & 97 & 145 & 83 & 133 & 152 & --. & 81 & 81 & 76 & 78 \\
\hline 6 & --- & 91 & 97 & 143 & 80 & 132 & -- & --- & 81 & 79 & 78 & 79 \\
\hline 7 & --- & 90 & 98 & 141 & 86 & 131 & -- & --- & 80 & 80 & 82 & 80 \\
\hline 8 & --- & 90 & 97 & 138 & 91 & 129 & 144 & 75 & 76 & 81 & 81 & 81 \\
\hline 9 & --- & 91 & 97 & 135 & 97 & 130 & 137 & 76 & 77 & 79 & 79 & 80 \\
\hline 10 & --- & 92 & --- & 144 & 102 & 125 & 118 & 82 & 76 & 79 & 79 & 81 \\
\hline 11 & --- & 93 & 97 & 144 & 112 & 121 & --- & --. & 77 & 81 & 76 & 83 \\
\hline 12 & --- & 92 & 97 & 174 & 124 & 115 & 100 & -- & --- & 84 & 75 & 83 \\
\hline 13 & --- & 93 & 97 & 185 & 130 & 115 & 96 & 78 & --- & 89 & 75 & 86 \\
\hline 14 & -.. & 92 & 97 & --- & 136 & 116 & 93 & 81 & 77 & 86 & ..- & 86 \\
\hline 15 & --. & 92 & 104 & 194 & 141 & 115 & 87 & 80 & 79 & 86 & --- & 89 \\
\hline 16 & --- & 94 & 111 & 164 & 144 & 115 & 88 & 81 & 77 & 87 & -- & 91 \\
\hline 17 & --- & 98 & 132 & 161 & 149 & 117 & 88 & 82 & --- & 83 & -- & 100 \\
\hline 18 & --- & 98 & 138 & 165 & 156 & --- & 90 & 82 & --. & 84 & --- & 101 \\
\hline 19 & -.. & 98 & 138 & ---- & 160 & 128 & 87 & 83 & --- & -.- & --. & 110 \\
\hline 20 & --- & 96 & 177 & 165 & 164 & --- & 90 & 85 & --- & --- & -.- & 151 \\
\hline 21 & --- & $\cdots$ & 187 & 165 & 170 & --. & 88 & 87 &.-- & 78 & $\ldots$ & 144 \\
\hline 22 & --- & $\cdots$ & 174 & 157 & 172 & --- & 87 & 90 & --- & 78 & --- & 134 \\
\hline 23 & --- & 98 & 167 & 152 & 170 & --- & 87 & 87 & --- & 78 & $\ldots$ & 113 \\
\hline 24 & --- & 99 & -- & 138 & 165 & --- & 86 & 87 & --- & 76 & $\ldots$ & 110 \\
\hline 25 & $\cdots$ & 100 & --. & 139 & 163 & --. & 86 & 89 & --- & 75 & --- & 133 \\
\hline 26 & --- & 99 & 70 & 129 & 161 & 140 & 84 & 85 & --- & 75 & --- & 121 \\
\hline 27 & --- & 100 & 93 & 130 & 156 & 141 & 85 & 88 & 81 & 78 & 73 & 127 \\
\hline 28 & --- & 96 & 123 & 134 & 155 & 141 & 85 & 83 & 82 & 79 & 73 & $\ldots$ \\
\hline 29 & --- & 97 & 123 & 136 & --- & 126 & 84 & 82 & 81 & 74 & 74 & 126 \\
\hline 30 & -.- & 98 & 132 & 141 & --- & 128 & 83 & 82 & 80 & 78 & 74 & 131 \\
\hline 31 & --- & --. & 146 & 113 & --- & 133 & --- & 84 & --- & 80 & 75 & --- \\
\hline
\end{tabular}

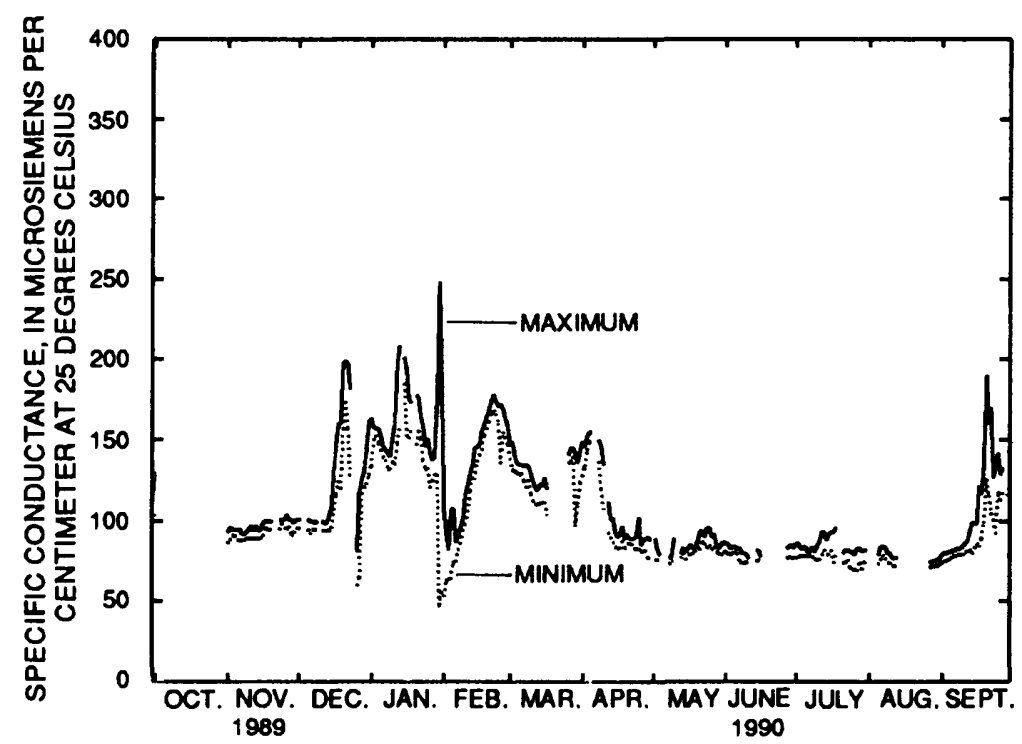


Table 2.--Daily mean values of specific conductance, near surface, in water at site 1, Chowan River near Edenhouse, October 1990 through April 1991

STATION NUMBER AND NAME: 0205365200, Chowan River near Edenhouse

LATITUDE: $36^{\circ} 02^{\prime} 52^{\prime \prime}$ LONGITUDE: $76^{\circ} 41^{\prime} 42^{\prime \prime}$ COUNTY: Bertie

PROBE LOCATION: 20 feet above bottom

[Specific conductance, microsiemens per centimeter at 25 degrees Celsius; ---, no data]

\begin{tabular}{|c|c|c|c|c|c|c|c|}
\hline Day & Oct. & Nov. & Dec. & Jan. & Feb. & Mar. & Apr. \\
\hline 1 & 123 & 187 & -.. & 108 & 212 & 170 & 216 \\
\hline 2 & 131 & 185 & --- & 108 & 203 & 166 & 217 \\
\hline 3 & 145 & 181 & --- & 107 & 193 & 166 & 219 \\
\hline 4 & 135 & 163 & --- & 106 & 194 & 163 & 210 \\
\hline 5 & 119 & 168 & --- & 108 & 196 & 165 & 186 \\
\hline 6 & 139 & 146 & --- & 108 & 198 & 164 & 167 \\
\hline 7 & 137 & 157 & -.. & 105 & 193 & 169 & 143 \\
\hline 8 & 144 & 158 & -.- & 104 & 179 & 172 & 126 \\
\hline 9 & 138 & 157 & -.- & 103 & 175 & 190 & 98 \\
\hline 10 & 133 & 165 & ... & 104 & 175 & 186 & 89 \\
\hline 11 & 137 & 139 & --- & 106 & 184 & 187 & 93 \\
\hline 12 & 150 & 144 & --- & 102 & 175 & 190 & --. \\
\hline 13 & 147 & 139 & 125 & 102 & 178 & 201 & 96 \\
\hline 14 & 152 & 142 & 124 & 100 & 172 & 203 & 95 \\
\hline 15 & 145 & 148 & 119 & 99 & 159 & 208 & 92 \\
\hline 16 & 154 & 136 & 122 & 99 & 161 & 215 & 98 \\
\hline 17 & 159 & 131 & 117 & 117 & 166 & 214 & 100 \\
\hline 18 & 162 & 122 & 114 & 133 & 165 & -.. & 103 \\
\hline 19 & 149 & 115 & 119 & 158 & 164 & $\cdots$ & 100 \\
\hline 20 & 151 & 120 & 113 & 192 & 163 & $\cdots$ & 101 \\
\hline 21 & 155 & 130 & 112 & 227 & 165 & $\cdots$ & 103 \\
\hline 22 & 157 & 154 & 109 & 236 & 166 & -.. & 103 \\
\hline 23 & 154 & 145 & 108 & 237 & 168 & 214 & 103 \\
\hline 24 & 151 & 137 & 109 & 223 & 165 & 220 & 103 \\
\hline 25 & 149 & 142 & 111 & 239 & 166 & 248 & 101 \\
\hline 26 & 131 & 139 & 109 & 240 & 169 & 233 & 103 \\
\hline 27 & 162 & 132 & 107 & 241 & 168 & 233 & 104 \\
\hline 28 & 219 & -- & 110 & 236 & 174 & 220 & 104 \\
\hline 29 & 207 & $\cdots$ & 120 & 232 & $\cdots$ & 217 & 108 \\
\hline 30 & 190 & --- & 118 & 229 & --- & 208 & 108 \\
\hline 31 & 193 & --. & 116 & 216 & -- & 220 & ... \\
\hline
\end{tabular}

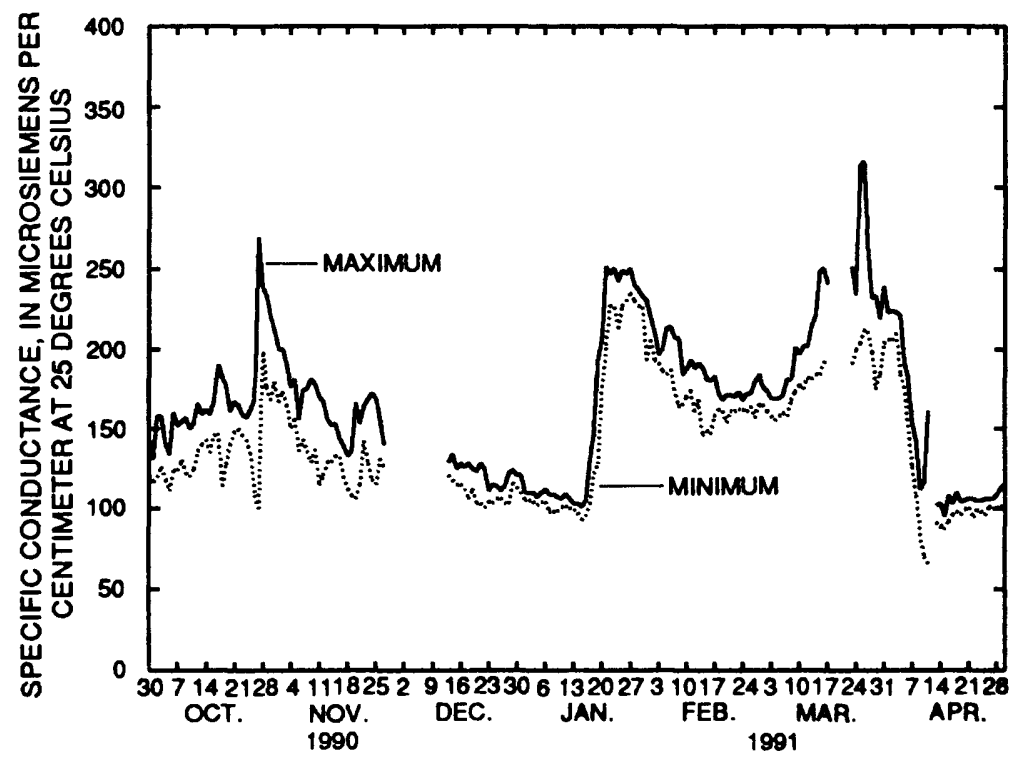


Table 3.--Daily mean values of salinity concentration, near surface, in water at site 1, Chowan River near Edenhouse, October 1989 through September 1990

STATION NUMBER AND NAME: 0205365200, Chowan River near Edenhouse

LATITUDE: $36^{\circ} 02^{\prime} 52^{\prime \prime}$ LONGITUDE: 76 $41^{\prime} 42^{\prime \prime}$ COUNTY: Bertie

PROBE LOCATION: 20 feet above bottom

[Salinity concentration, parts per thousand; ---, no data]

\begin{tabular}{|c|c|c|c|c|c|c|c|c|c|c|c|c|}
\hline DAY & Oct. & Nov. & Dec. & Jan. & Feb. & Mar. & Apr. & May & June & July & Aug. & Sept. \\
\hline 1 & 0.04 & 0.04 & 0.04 & 0.06 & 0.03 & 0.06 & 0.06 & -.. & 0.03 & 0.03 & --- & 0.03 \\
\hline 2 & ... & .04 & .04 & .06 & .03 & .06 & .06 & 0.03 & .03 & .03 & -.. & .03 \\
\hline 3 & $\ldots$ & .04 & --- & .06 & .03 & .05 & .06 & .03 & .03 & .03 & 0.03 & .03 \\
\hline 4 & -- & .04 & -.- & .06 & .03 & .05 & .06 & .03 & .03 & .03 & $\ldots$ & .03 \\
\hline 5 & $\cdots$ & .04 & .04 & .06 & .03 & .05 & .06 & $\cdots$ & .03 & .03 & .03 & .03 \\
\hline 6 & --- & .04 & .04 & .06 & .03 & .05 & --. & --- & .03 & .03 & .03 & .03 \\
\hline 7 & -- & .04 & .04 & .06 & .03 & .05 & --- & --- & .03 & .03 & .03 & .03 \\
\hline 8 & --- & .04 & .04 & .06 & .04 & .05 & .06 & .03 & .03 & .03 & .03 & .03 \\
\hline 9 & --- & .04 & .04 & .05 & .04 & .05 & .05 & .03 & .03 & .03 & .03 & .03 \\
\hline 10 & $\ldots$ & .04 &.- & .06 & .04 & .05 & .05 & .03 & .03 & .03 & .03 & .03 \\
\hline 11 & --- & .04 & .04 & .06 & .04 & .05 & --- & --- & .03 & .03 & .03 & .03 \\
\hline 12 & -- & .04 & .04 & .07 & .05 & .05 & .04 & -- & -- & .03 & .03 & .03 \\
\hline 13 & -- & .04 & .04 & .07 & .05 & .05 & .04 & .03 & --. & .04 & .03 & .03 \\
\hline 14 & -- & .04 & .04 & -.- & .05 & .05 & .04 & .03 & .03 & .03 & --. & .03 \\
\hline 15 & $\cdots$ & .04 & .04 & .08 & .06 & .05 & .03 & .03 & .03 & .03 & --- & .04 \\
\hline 16 & --. & .04 & .04 & .07 & .06 & .05 & .04 & .03 & .03 & .03 & -.- & .04 \\
\hline 17 & --. & .04 & .05 & .06 & .06 & .05 & .04 & .03 & --- & .03 & --- & .04 \\
\hline 18 & --- & .04 & .06 & .07 & .06 & ... & .04 & .03 & -- & .03 & $\ldots$ & .04 \\
\hline 19 & --- & .04 & .06 & -.. & .06 & .05 & .03 & .03 & --- & --- & -.. & .04 \\
\hline 20 & --- & .04 & .07 & .07 & .07 & -- & .04 & .03 & $\ldots$ & -- & -.- & .06 \\
\hline 21 & -- & --- & .07 & .07 & .07 & --. & .04 & .03 & --- & .03 & $\ldots$ & .06 \\
\hline 22 & --- & --- & .07 & .06 & .07 & --- & .03 & .04 & --- & .03 & --- & .05 \\
\hline 23 & --- & .04 & .07 & .06 & .07 & --. & .03 & .03 & --. & .03 & $-\cdots$ & .05 \\
\hline 24 & --- & .04 & -.. & .06 & .07 & --. & .03 & .03 & --- & .03 & -.. & .04 \\
\hline 25 & --- & .04 & -.. & .06 & .07 & --. & .03 & .04 & --- & .03 & --. & .05 \\
\hline 26 & --- & .04 & .03 & .05 & .06 & .06 & .03 & .03 & --- & .03 & --. & .05 \\
\hline 27 & --- & .04 & .04 & .05 & .06 & .06 & .03 & .04 & .03 & .03 & .03 & .05 \\
\hline 28 & --- & .04 & .05 & .05 & .06 & .06 & .03 & .03 & .03 & .03 & .03 & $\ldots$ \\
\hline 29 & --- & .04 & .05 & .05 & -- & .05 & .03 & .03 & .03 & .03 & .03 & .05 \\
\hline 30 & --- & .04 & .05 & .06 & --- & .05 & .03 & .03 & .03 & .03 & .03 & .05 \\
\hline 31 & -- & --. & .06 & .05 & -- & .05 & --- & .03 & --- & .03 & .03 & --. \\
\hline
\end{tabular}

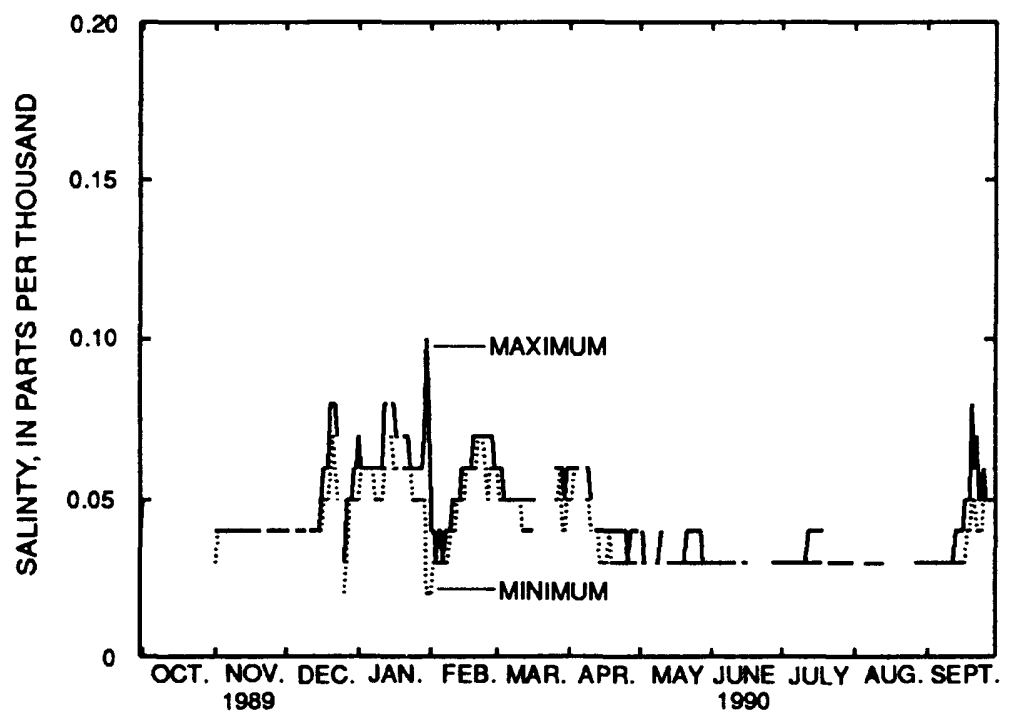


Table 4.--Daily mean values of salinity concentration, near surface, in water at site 1, Chowan River near Edenhouse, October 1990 through April 1991

STATION NUMBER AND NAME: 0205365200, Chowan River near Edenhouse

LATITUDE: $36^{\circ} 02^{\prime} 52^{\prime \prime}$ LONGITUDE: $76^{\circ} 41^{\prime} 42^{\prime \prime}$ COUNTY: Bertie PROBE LOCATION: 20 feet above bottom

[Salinity concentrations, parts per thousand; ---, no data]

\begin{tabular}{|c|c|c|c|c|c|c|c|}
\hline Day & Oct. & Nov. & Dec. & Jan. & Feb. & Mar. & Apr. \\
\hline 1 & 0.05 & 0.07 & $\cdots$ & 0.04 & 0.09 & 0.07 & 0.09 \\
\hline 2 & .05 & .07 & --- & .04 & .08 & .07 & .09 \\
\hline 3 & .06 & .07 & --- & .04 & .08 & .07 & .09 \\
\hline 4 & .05 & .07 & --- & .04 & .08 & .07 & .09 \\
\hline 5 & .05 & .07 & -.- & .04 & .08 & .07 & .07 \\
\hline 6 & .06 & .06 & --- & .04 & .08 & .07 & .07 \\
\hline 7 & .05 & .06 & -.. & .04 & .08 & .07 & .06 \\
\hline 8 & .06 & .06 & -.- & .04 & .07 & .07 & .05 \\
\hline 9 & .06 & .06 & $\ldots$ & .04 & .07 & .08 & .04 \\
\hline 10 & .05 & .07 & $\cdots$ & .04 & .07 & .07 & .04 \\
\hline 11 & .05 & .06 & $\ldots$ & .04 & .07 & .07 & .04 \\
\hline 12 & .06 & .06 & --- & .04 & .07 & .08 & --- \\
\hline 13 & .06 & .06 & 0.05 & .04 & .07 & .08 & .04 \\
\hline 14 & .06 & .06 & .05 & .04 & .07 & .08 & .04 \\
\hline 15 & .06 & .06 & .05 & .04 & .06 & .08 & .04 \\
\hline 16 & .06 & .05 & .05 & .04 & .06 & .09 & .04 \\
\hline 17 & .06 & .05 & .05 & .05 & .07 & .09 & .04 \\
\hline 18 & .06 & .05 & .05 & .05 & .07 & -.. & .04 \\
\hline 19 & .06 & .05 & .05 & .06 & .07 & $\ldots$ & .04 \\
\hline 20 & .06 & .05 & .05 & .08 & .07 & --- & .04 \\
\hline 21 & .06 & .05 & .04 & .09 & .07 & --- & .04 \\
\hline 22 & .06 & .06 & .04 & .10 & .07 & $\cdots$ & .04 \\
\hline 23 & .06 & .06 & .04 & .10 & .07 & .09 & .04 \\
\hline 24 & .06 & .05 & .04 & .09 & .07 & .09 & .04 \\
\hline 25 & .06 & .06 & .04 & .10 & .07 & .10 & .04 \\
\hline 26 & .05 & .06 & .04 & .10 & .07 & .10 & .04 \\
\hline 27 & .07 & .05 & .04 & .10 & .07 & .10 & .04 \\
\hline 28 & .09 & -.- & .04 & .10 & .07 & .09 & .04 \\
\hline 29 & .08 & --- & .05 & .10 & -- & .09 & .04 \\
\hline 30 & .08 & --- & .05 & .09 & -.- & .08 & .04 \\
\hline 31 & .08 & --. & .05 & .09 & -- & .09 & $\cdots$ \\
\hline
\end{tabular}

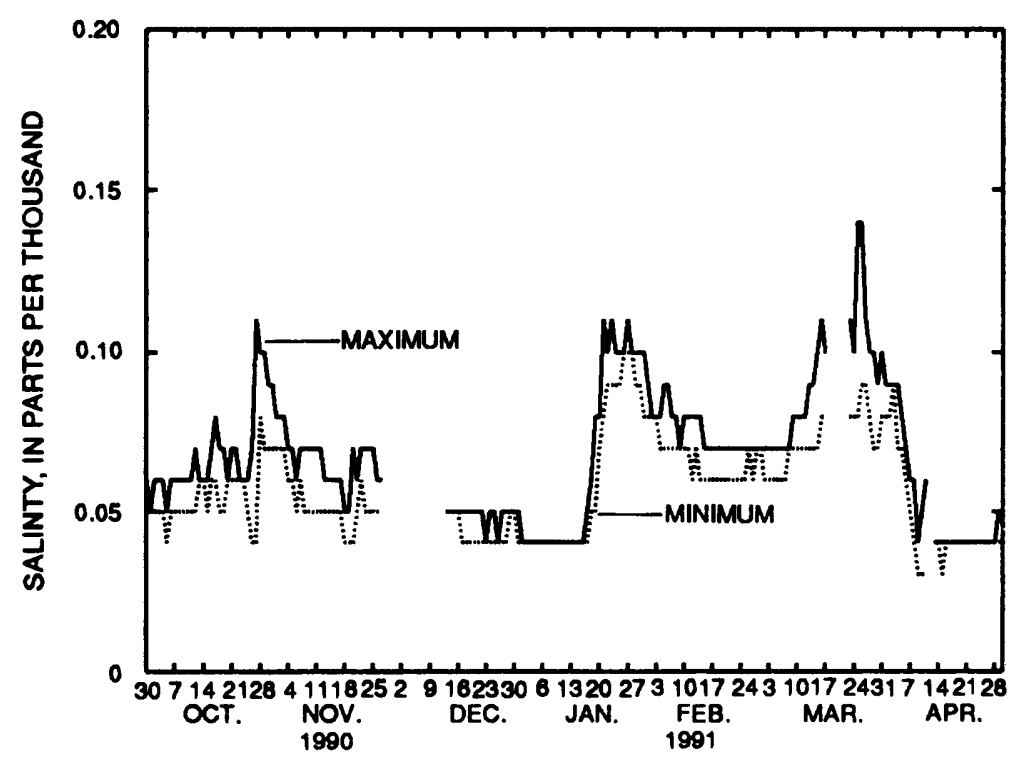


Table 5.--Daily mean values of specific conductance, near bottom, in water at site 1, Chowan River near Edenhouse, October 1989 through September 1990

STATION NUMBER AND NAME: 0205365200, Chowan River near Edenhouse

LATITUDE: $36^{\circ} 02^{\prime} 52^{\prime \prime}$ LONGITUDE: 76 $41^{\prime} 42^{\prime \prime}$ COUNTY: Bertie

PROBE LOCATION: 5 feet above bottom

[Specific conductance, microsiemens per centimeter at 25 degrees Celsius; ---, no data]

\begin{tabular}{|c|c|c|c|c|c|c|c|c|c|c|c|c|}
\hline Day & Oct. & Nov. & Dec. & Jan. & Feb. & Mar. & Apr. & May & June & July & Aug. & Sept. \\
\hline 1 & 108 & 91 & 98 & 152 & 1,010 & 149 & 140 & --- & --. & --- & $\ldots$ & 81 \\
\hline 2 & -- & 93 & 98 & 156 & 704 & 142 & 143 & 76 & --. & --. & $-\cdots$ & 82 \\
\hline 3 & --- & 93 & 97 & 157 & 562 & 140 & 147 & 76 & $\cdots$ & -- & 80 & 82 \\
\hline 4 & -- & 94 & 98 & 153 & 519 & 138 & 152 & 77 & --- & --- & --- & 82 \\
\hline 5 & --- & 93 & 97 & 145 & 296 & 136 & 151 & -- & --- & $\cdots$ & 80 & 84 \\
\hline 6 & -- & 92 & 96 & 141 & 268 & 137 & --- & -- & --- & -.. & 84 & 83 \\
\hline 7 & -- & 92 & 96 & 139 & 261 & 133 & --. & -.. & --- & -.. & 86 & 83 \\
\hline 8 & --- & 92 & 96 & 137 & 254 & 130 & 144 & --- & $\cdots$ & ... & 86 & 82 \\
\hline 9 & $\cdots$ & 92 & 96 & 134 & 246 & 132 & 139 & --- & --- & 74 & 84 & 82 \\
\hline 10 & --- & 93 & 97 & 142 & 243 & 129 & 117 & --- & --- & 74 & 81 & 86 \\
\hline 11 & $\ldots$ & 94 & 96 & 146 & 244 & 124 & $\ldots$ & --- & --- & 78 & 82 & 98 \\
\hline 12 & -- & 92 & 96 & 181 & 254 & 119 & 98 & --- & --. & 78 & 80 & 89 \\
\hline 13 & --- & 93 & 95 & 197 & 253 & 116 & 95 & --- & --. & 86 & 78 & 90 \\
\hline 14 & --- & 92 & 97 & --- & 248 & 115 & 93 & 75 & --- & 82 & -.. & 91 \\
\hline 15 & $\cdots$ & 93 & 102 & 201 & 244 & 116 & 88 & --. & --- & 83 & -.- & 95 \\
\hline 16 & -- & 94 & 110 & 180 & 229 & 116 & 86 & --- & --- & 91 & -- & 100 \\
\hline 17 & -- & 99 & 137 & 164 & 220 & 117 & 88 & --- & --- & 81 & --- & 100 \\
\hline 18 & -- & 99 & 141 & 167 & 213 & -.- & 90 & 75 & --- & 72 & --- & 99 \\
\hline 19 & $\cdots$ & 99 & 140 & --- & 203 & 129 & 87 & --- & --- & --- & --- & 119 \\
\hline 20 & $\cdots$ & 97 & 183 & 166 & 192 &.-- & 89 & 78 & --- & -- & -.. & 167 \\
\hline 21 & --- & -- & 194 & 166 & 188 & -- & 88 & --- & --- & 78 & $\cdots$ & 152 \\
\hline 22 & -- & --- & 178 & 156 & 180 & --- & 86 & -- & --- & 78 & --- & 180 \\
\hline 23 & -- & 99 & 175 & 149 & 176 & --- & 87 & 89 & -- & 77 & --- & 123 \\
\hline 24 & $\cdots$ & 99 & 163 & 136 & 172 & --- & 85 & -+ & --- & 77 & --- & 130 \\
\hline 25 & -- & 100 & 153 & 133 & 171 & --- & 84 & --- & --. & 77 & --- & 135 \\
\hline 26 & -- & 98 & 120 & 121 & 169 & 140 & 84 & -.. & -.. & 77 & ... & 125 \\
\hline 27 & $\cdots$ & 98 & 121 & 122 & 164 & 140 & 82 & $\cdots$ & --- & 81 & 79 & 134 \\
\hline 28 & --- & 95 & 124 & 174 & 160 & 141 & 77 & $\cdots$ & --- & 80 & 80 & --- \\
\hline 29 & --- & 97 & 122 & 264 & --- & 125 & 76 & $\cdots$ & --- & 78 & 80 & 124 \\
\hline 30 & $\cdots$ & 98 & 134 & 1,060 & -- & 124 & 75 & --- & $\cdots$ & 84 & 80 & 131 \\
\hline 31 & $\cdots$ & -.. & 148 & 1,460 & --. & 129 & -- & $\cdots$ & -- & 83 & 80 & --- \\
\hline
\end{tabular}

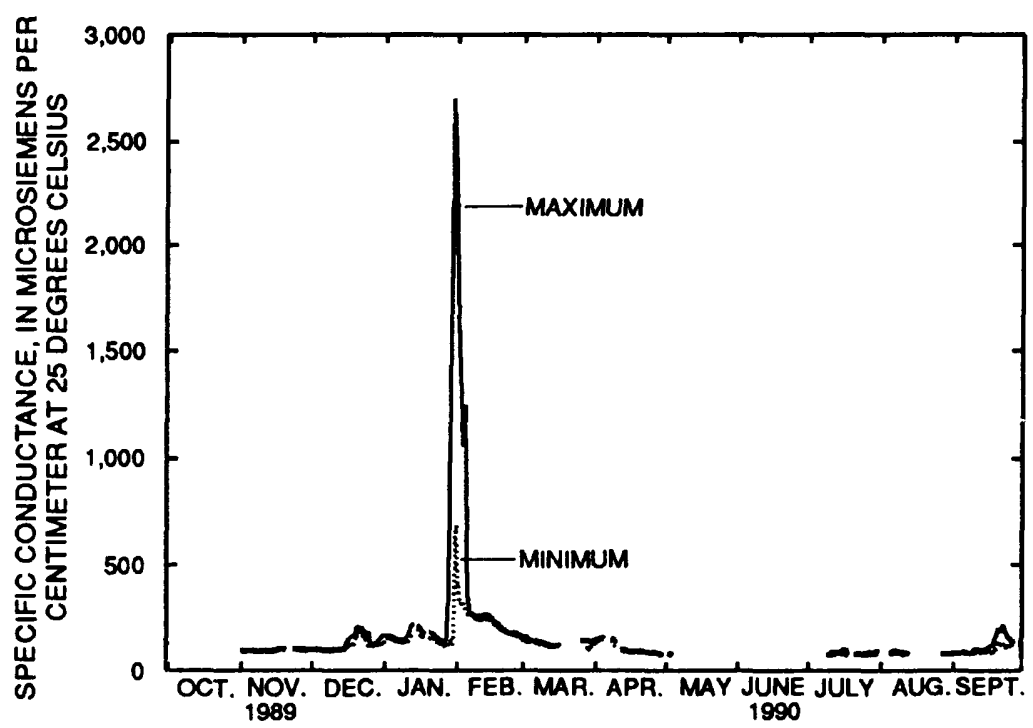


Table 6.--Daily mean values of specific conductance, near bottom, in water at site 1, Chowan River near Edenhouse, October 1990 through April 1991

STATION NUMBER AND NAME: 0205365200, Chowan River near Edenhouse

LATITUDE: $36^{\circ} 02^{\prime} 52^{\prime \prime}$ LONGITUDE: $76^{\circ} 41^{\prime} 42^{\prime \prime}$ COUNTY: Bertie

PROBE LOCATION: 5 feet above bottom

[Specific conductance, microsiemens per centimeter at 25 degrees Celsius; ---, no data]

\begin{tabular}{|c|c|c|c|c|c|c|c|}
\hline Day & Oct. & Nov. & Dec. & Jan. & Feb. & Mar. & Apr. \\
\hline 1 & 118 & 186 & --. & 109 & 224 & 169 & 232 \\
\hline 2 & 130 & 166 & --- & 108 & 210 & 164 & 233 \\
\hline 3 & 132 & 166 & --- & 108 & 202 & 163 & 236 \\
\hline 4 & 132 & 160 & --- & 107 & 202 & 161 & 230 \\
\hline 5 & 107 & 159 & --- & 108 & 183 & 163 & 200 \\
\hline 6 & 110 & 155 & --- & 107 & 176 & 163 & 188 \\
\hline 7 & 124 & 163 & --- & 105 & 174 & 168 & 164 \\
\hline 8 & 120 & 163 & --- & 105 & 179 & 172 & 145 \\
\hline 9 & 105 & 166 & --- & 103 & 175 & 191 & 106 \\
\hline 10 & 107 & 175 & -- & 105 & 183 & 188 & 101 \\
\hline 11 & 129 & 146 & --- & 106 & 189 & 189 & 97 \\
\hline 12 & 143 & 156 & -.. & 103 & 179 & 202 & --. \\
\hline 13 & 146 & 148 & 130 & 103 & 183 & 205 & 84 \\
\hline 14 & 143 & 151 & 127 & 101 & 175 & 208 & 84 \\
\hline 15 & 147 & 152 & 123 & 98 & 160 & 214 & 82 \\
\hline 16 & 151 & 134 & 125 & 99 & 163 & 226 & 86 \\
\hline 17 & 154 & 129 & 119 & 119 & 170 & 237 & 93 \\
\hline 18 & 157 & 119 & 115 & 137 & 170 & --- & 91 \\
\hline 19 & 153 & 113 & 120 & 171 & 166 & --- & 90 \\
\hline 20 & 152 & 118 & 115 & 205 & 164 & --- & 92 \\
\hline 21 & 150 & 128 & 115 & 241 & 166 & --- & 93 \\
\hline 22 & 153 & 155 & 113 & 252 & 168 & --- & 94 \\
\hline 23 & 155 & 146 & 111 & 252 & 170 & 236 & 95 \\
\hline 24 & 149 & 136 & 111 & 237 & 165 & 231 & 95 \\
\hline 25 & 153 & 142 & 112 & 255 & 165 & 250 & 93 \\
\hline 26 & 131 & 139 & 110 & 256 & 166 & 245 & 94 \\
\hline 27 & 157 & 132 & 108 & 257 & 166 & 248 & 95 \\
\hline 28 & 236 &.-- & 114 & 250 & 174 & 233 & 88 \\
\hline 29 & 220 & $\cdots$ & 122 & 246 & -.- & 239 & 83 \\
\hline 30 & 174 & $--\cdot$ & 121 & 241 & -- & 224 & 84 \\
\hline 31 & 202 & --. & 118 & 227 & -- & 239 & --- \\
\hline
\end{tabular}

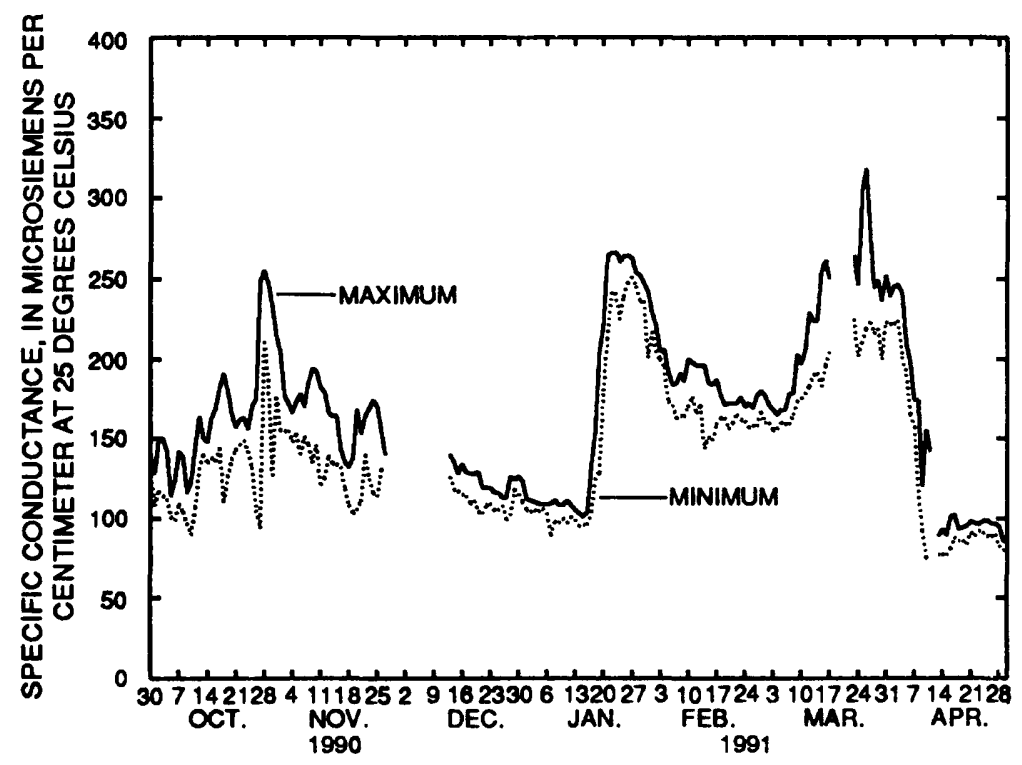


Table 7.--Daily mean values of salinity concentration, near bottom, in water at site 1, Chowan River near Edenhouse, October 1989 through September 1990

STATION NUMBER AND NAME: 0205365200, Chowan River near Edenhouse

LATITUDE: $36^{\circ} 02^{\prime} 52^{\prime \prime}$ LONGITUDE: $76^{\circ} 41^{\prime} 42^{\prime \prime}$. COUNTY: Bertie

PROBE LOCATION: 5 feet above bottom

[Salinity concentration, parts per thousand; ---, no data]

\begin{tabular}{|c|c|c|c|c|c|c|c|c|c|c|c|c|}
\hline Day & Oct. & Nov. & Dec. & Jan & Feb. & Mar. & Apr. & May & June & July & Aug. & Sept. \\
\hline 1 & 0.04 & 0.04 & 0.04 & 0.06 & 0.48 & 0.06 & 0.06 & -.. & ... & -- & --- & 0.03 \\
\hline 2 & --. & .04 & .04 & .06 & .33 & .06 & .06 & 0.03 & -.- & $\ldots$ & -.. & .03 \\
\hline 3 & --- & .04 & .04 & .06 & .26 & .06 & .06 & .03 & -.- & --- & 0.03 & .03 \\
\hline 4 & -.- & .04 & .04 & .06 & .24 & .06 & .06 & .03 & --. & --. & -.. & .03 \\
\hline 5 & $\cdots$ & .04 & .04 & .06 & .13 & .05 & .06 & -.. & --- & --. & .03 & .03 \\
\hline 6 & --- & .04 & .04 & .06 & .11 & .05 & --. & -.. & --- & -- & .03 & .03 \\
\hline 7 & $\ldots$ & .04 & .04 & .06 & .11 & .05 & --- & --- & -- & -.. & .03 & .03 \\
\hline 8 & -- & .04 & .04 & .05 & .11 & .05 & .06 & --- & --- & $\ldots$ & .03 & .03 \\
\hline 9 & --- & .04 & .04 & .05 & .10 & .05 & .06 & --. & --- & 0.03 & .03 & .03 \\
\hline 10 & -.. & .04 & .04 & .06 & .10 & .05 & .05 & --- & -- & .03 & .03 & .03 \\
\hline 11 & -- & .04 & .04 & .06 & .10 & .05 & --- & -.. & --- & .03 & .03 & .04 \\
\hline 12 & --- & .04 & .04 & .07 & .11 & .05 & .04 & $\cdots$ & --- & .03 & .03 & .04 \\
\hline 13 & --- & .04 & .04 & .08 & .11 & .05 & .04 & --. & --. & .03 & .03 & .04 \\
\hline 14 & --- & .04 & .04 & -.. & .10 & .05 & .04 & .03 & --- & .03 & -- & .04 \\
\hline 15 & --- & .04 & .04 & .08 & .10 & .05 & .04 & $\cdots$ & $\cdots$ & .03 & --- & .04 \\
\hline 16 & --- & .04 & .04 & .07 & .09 & .05 & .03 & -.. & $\ldots$ & .04 & $\ldots$ & .04 \\
\hline 17 & --- & .04 & .05 & .07 & .09 & .05 & .04 & --. & --- & .03 & --- & .04 \\
\hline 18 & --- & .04 & .06 & .07 & .09 & --- & .04 & .03 & --- & .03 & --- & .04 \\
\hline 19 & -- & .04 & .06 & --- & .08 & .05 & .03 & --- & --- & --- & --- & .05 \\
\hline 20 & --- & .04 & .07 & .07 & .08 & -- & .04 & .03 & $\ldots$ & -- & --- & .07 \\
\hline 21 & -- & --- & .08 & .07 & .08 & -.. & .04 & -.. & --- & .03 & ... & .06 \\
\hline 22 & -- & $\cdots$ & .07 & .06 & .07 & --- & .03 & --- & --. & .03 & -.. & .07 \\
\hline 23 & --- & .04 & .07 & .06 & .07 & --- & .03 & .04 & $\ldots$ & .03 & -.- & .05 \\
\hline 24 & $\cdots$ & .04 & .07 & .05 & .07 & --- & .03 & ... & --- & .03 & -.. & .05 \\
\hline 25 & --- & .04 & .06 & .05 & .07 & --- & .03 & --. & --. & .03 & --- & .05 \\
\hline 26 & --- & .04 & .05 & .05 & .07 & .06 & .03 & --- & -- & .03 & -- & .05 \\
\hline 27 & --- & .04 & .05 & .05 & .07 & .06 & .03 & --- & -- & .03 & .03 & .05 \\
\hline 28 & --- & .04 & .05 & .07 & .06 & .06 & .03 & -.. & $\ldots$ & .03 & .03 & --- \\
\hline 29 & --- & .04 & .05 & .11 & --. & .05 & .03 & -.- & -- & .03 & .03 & .05 \\
\hline 30 & --- & .04 & .05 & .51 & --- & .05 & .03 & --- & -.- & .03 & .03 & .05 \\
\hline 31 & --- & $\ldots$ & .06 & .72 & --. & .05 & --- & -.- & $\cdots$ & .03 & .03 & ... \\
\hline
\end{tabular}

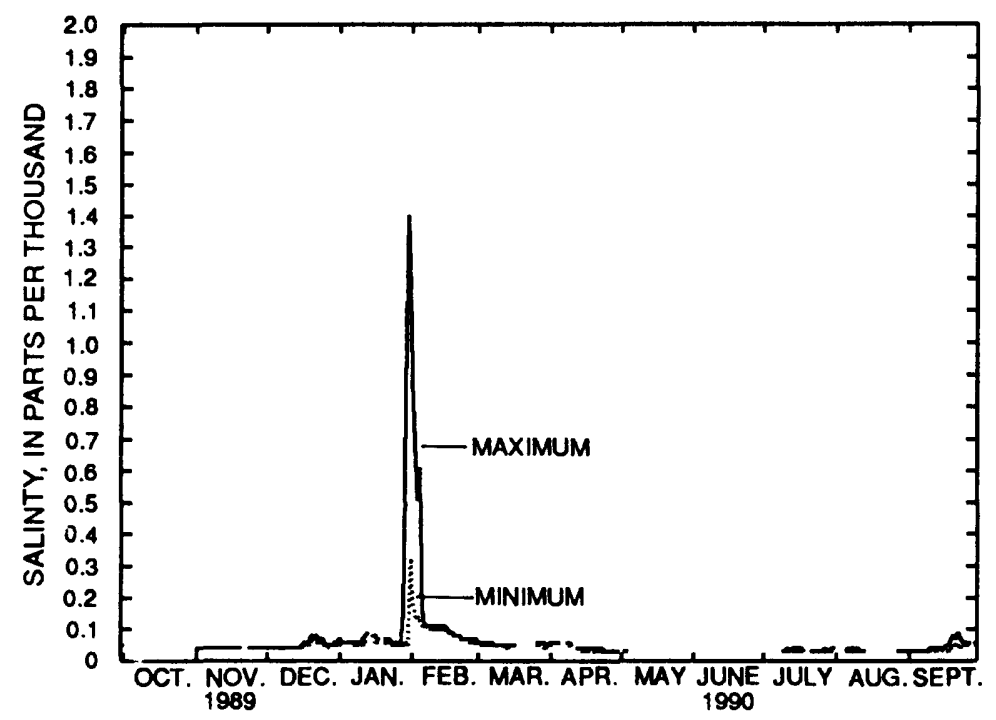


Table 8.--Daily mean values of salinity concentration, near bottom, in water at site 1, Chowan River near Edenhouse, October 1990 through April 1991

STATION NUMBER AND NAME: 0205365200, Chowan River near Edenhouse

LATITUDE: $36^{\circ} 02^{\prime} 52^{\prime \prime}$ LONGITUDE: $76^{\circ} 41^{\prime} 42^{\prime \prime}$ COUNTY: Bertie

PROBE LOCATION: 5 feet above bottom

[Salinity concentration, parts per thousand; ---, no data]

\begin{tabular}{|c|c|c|c|c|c|c|c|}
\hline Day & Oct. & Nov. & Dec. & Jan. & Feb. & Mar. & Apr. \\
\hline 1 & 0.05 & 0.07 & --- & 0.04 & 0.09 & 0.07 & 0.10 \\
\hline 2 & .05 & .07 & -.. & .04 & .09 & .07 & .10 \\
\hline 3 & .05 & .07 & --- & .04 & .08 & .07 & .10 \\
\hline 4 & .05 & .06 & $\ldots$ & .04 & .08 & .06 & .09 \\
\hline 5 & .04 & .06 & -- & .04 & .07 & .07 & .08 \\
\hline 6 & .04 & .06 & --- & .04 & .07 & .07 & .08 \\
\hline 7 & .05 & .07 & --- & .04 & .07 & .07 & .07 \\
\hline 8 & .05 & .07 & -.. & .04 & .07 & .07 & .06 \\
\hline 9 & .04 & .07 & --- & .04 & .07 & .08 & .04 \\
\hline 10 & .04 & .07 & --- & .04 & .07 & .08 & .04 \\
\hline 11 & .05 & .06 & -- & .04 & .08 & .08 & .04 \\
\hline 12 & .06 & .06 & -.- & .04 & .07 & .08 & -.. \\
\hline 13 & .06 & .06 & 0.05 & .04 & .07 & .08 & .03 \\
\hline 14 & .06 & .06 & .05 & .04 & .07 & .08 & .03 \\
\hline 15 & .06 & .06 & .05 & .04 & .06 & .09 & .03 \\
\hline 16 & .06 & .05 & .05 & .04 & .07 & .09 & .03 \\
\hline 17 & .06 & .05 & .05 & .05 & .07 & .10 & .04 \\
\hline 18 & .06 & .05 & .05 & .05 & .07 & -- & .04 \\
\hline 19 & .06 & .05 & .05 & .07 & .07 & -.- & .04 \\
\hline 20 & .06 & .05 & .05 & .08 & .07 & -- & .04 \\
\hline 21 & .06 & .05 & .05 & .10 & .07 & --- & .04 \\
\hline 22 & .06 & .06 & .05 & .11 & .07 & --- & .04 \\
\hline 23 & .06 & .06 & .04 & .11 & .07 & .10 & .04 \\
\hline 24 & .06 & .05 & .04 & .10 & .07 & .10 & .04 \\
\hline 25 & .06 & .06 & .04 & .11 & .07 & .11 & .04 \\
\hline 26 & .05 & .06 & .04 & .11 & .07 & .10 & .04 \\
\hline 27 & .06 & .05 & .04 & .11 & .07 & .10 & .04 \\
\hline 28 & .10 & --- & .05 & .10 & .07 & .10 & .04 \\
\hline 29 & .09 & -.- & .05 & .10 & $\ldots$ & .10 & .03 \\
\hline 30 & .07 & --- & .05 & .10 & --- & .09 & .03 \\
\hline 31 & .08 & -.. & .05 & .09 & --- & .10 & $\ldots$ \\
\hline
\end{tabular}

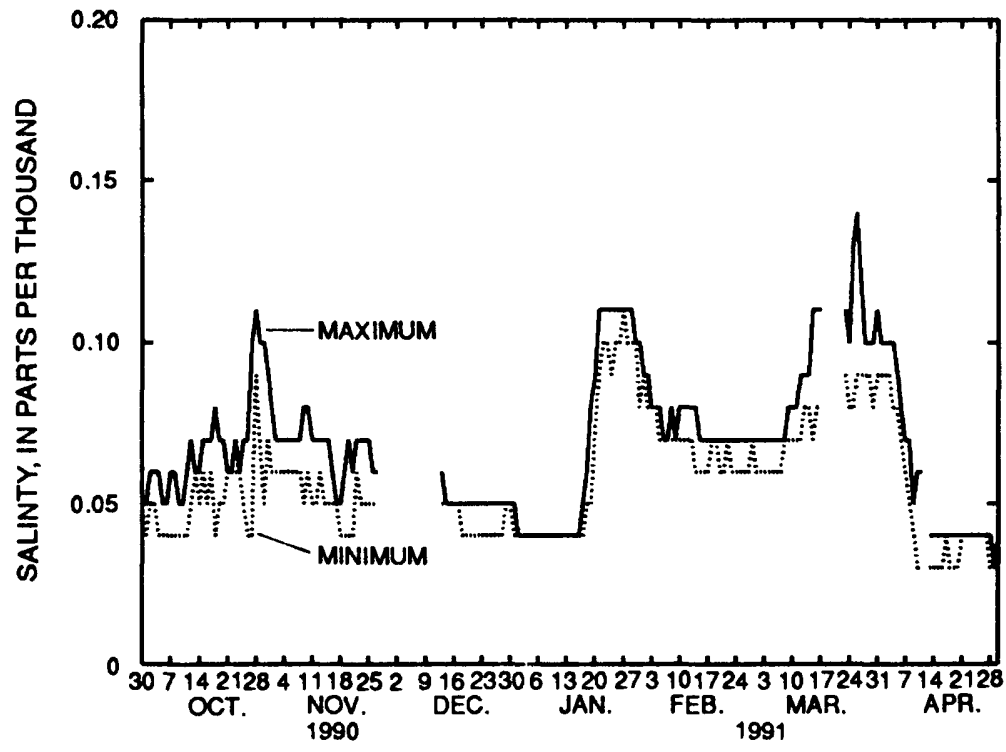


Table 9.--Daily mean values of water temperature, near surface, in water at site 1, Chowan River near Edenhouse, October 1989 through September 1990

STATION NUMBER AND NAME: 0205365200, Chowan River near Edenhouse

LATITUDE: $36^{\circ} 02^{\prime} 52^{\prime \prime}$ LONGITUDE: $76^{\circ} 41^{\prime} 42^{\prime \prime}$ COUNTY: Bertie

PROBE LOCATION: 20 feet above bottom

[Water temperature, degrees Celsius; ---, no data]

\begin{tabular}{|c|c|c|c|c|c|c|c|c|c|c|c|c|}
\hline Day & Oct. & Nov. & Dec. & Jan & Feb. & Mar. & Apr. & May & June & July & Aug. & Sept. \\
\hline 1 & 21.4 & 18.3 & 10.5 & 0.6 & 10.0 & 9.5 & 13.6 & --- & 22.8 & 28.8 & -.- & 28.2 \\
\hline 2 & --- & 18.1 & 10.2 & .9 & 10.5 & 9.6 & 14.0 & 22.2 & 23.1 & 28.0 & -.. & 28.2 \\
\hline 3 & --- & 17.9 & 9.5 & 1.3 & 11.0 & 10.2 & 14.0 & 21.7 & 23.3 & 28.3 & 28.3 & 28.1 \\
\hline 4 & --- & 17.3 & 8.1 & 1.7 & 11.4 & 10.1 & 13.8 & 21.5 & 24.2 & 28.0 & -.. & 27.5 \\
\hline 5 & --. & 16.9 & 7.6 & 2.4 & 11.1 & 10.1 & 14.0 & --- & 24.1 & 28.4 & 28.2 & 27.5 \\
\hline 6 & -.. & 17.0 & 7.7 & 3.0 & 10.6 & 10.7 & --- & $\cdots$ & 24.2 & 28.7 & 28.1 & 27.7 \\
\hline 7 & --- & 17.5 & 8.1 & 3.2 & 10.8 & 10.2 & --- & --- & 24.9 & 28.4 & 27.7 & 27.7 \\
\hline 8 & --- & 17.7 & 7.9 & 3.5 & 11.2 & 9.8 & 14.2 & 21.6 & 25.7 & 28.7 & 27.5 & 27.4 \\
\hline 9 & --- & 17.6 & 7.2 & 3.6 & 11.3 & 10.2 & 14.7 & 21.7 & 26.4 & 29.2 & 27.3 & 27.2 \\
\hline 10 & --. & 17.5 & 6.1 & 3.9 & 12.0 & 11.0 & 14.5 & 21.4 & 26.9 & 29.8 & 27.3 & 27.6 \\
\hline 11 & --- & 17.2 & 6.0 & 4.3 & 12.1 & 11.9 & -- & $\ldots$ & 25.7 & 29.9 & 28.2 & 27.5 \\
\hline 12 & --. & 17.0 & 6.0 & 4.6 & 11.7 & 13.8 & 15.1 & -.. & $\ldots$ & 29.7 & 28.6 & 27.7 \\
\hline 13 & --. & 17.1 & 6.0 & 4.5 & 11.6 & 14.4 & 14.7 & 21.0 & --- & 29.6 & 28.8 & 27.6 \\
\hline 14 & --. & 17.5 & 5.7 & $\ldots$ & 11.9 & 15.7 & 14.8 & 21.7 & 25.2 & 29.2 & -.- & 27.6 \\
\hline 15 & --- & 17.8 & 5.4 & 4.7 & 12.3 & 15.5 & 15.3 & 22.3 & 24.9 & 28.8 & -.- & 27.3 \\
\hline 16 & --- & 17.8 & 5.2 & 5.6 & 13.1 & 15.3 & 15.6 & 22.7 & 25.0 & 28.6 & -- & 27.5 \\
\hline 17 & ... & 16.8 & 4.2 & 5.8 & 13.7 & 16.0 & 16.2 & 23.2 & $\cdots$ & 28.8 & -.. & 26.3 \\
\hline 18 & $\ldots$ & 16.0 & 3.9 & 6.2 & 13.4 & -.. & 16.4 & 22.8 & --. & 29.0 & -.- & 25.2 \\
\hline 19 & --. & 15.2 & 3.6 & -. & 13.2 & 16.3 & 16.1 & 22.8 & ... & -.. & --. & 24.5 \\
\hline 20 & --- & 14.2 & 3.0 & 6.8 & 12.7 & -- & 16.5 & 22.8 & -- & $\ldots$ & $\cdots$ & 24.2 \\
\hline 21 & -.. & --. & 2.8 & 7.3 & 12.1 & --- & 16.7 & 23.2 & --- & 28.5 & $\cdots$ & 23.9 \\
\hline 22 & --- & ... & 2.1 & 7.9 & 12.0 & $\ldots$ & 17.0 & 22.5 & --. & 29.2 & $\cdots$ & 23.7 \\
\hline 23 & -.. & 11.8 & .8 & 8.1 & 12.3 & --- & 18.3 & 21.6 & --- & 29.2 & -. & 23.8 \\
\hline 24 & -.. & 10.6 & .0 & 8.4 & 12.3 & $\cdots$ & 19.2 & 21.6 & -.. & 28.9 & $\ldots$ & 23.0 \\
\hline 25 & --- & 10.1 & .0 & 8.9 & 11.1 & -.. & 19.9 & 21.7 & $\ldots$ & 28.8 & -.. & 22.6 \\
\hline 26 & --. & 10.3 & .0 & 9.3 & 9.5 & -.. & 21.8 & 21.6 & $\ldots$ & 28.5 & --- & 22.4 \\
\hline 27 & --- & 10.9 & .0 & 9.1 & 9.1 & 14.3 & 23.0 & 21.8 & 28.2 & 28.3 & 29.3 & 22.4 \\
\hline 28 & --- & 11.0 & .1 & 9.2 & 9.1 & 14.1 & 22.0 & 21.4 & 28.4 & 28.2 & 29.5 & -.. \\
\hline 29 & --- & 11.2 & .1 & 9.5 & -- & 13.4 & 21.2 & 21.5 & 28.5 & 28.3 & 29.4 & 22.2 \\
\hline 30 & --- & 10.6 & .1 & 9.6 & --- & 13.4 & 21.1 & 21.6 & 28.5 & 28.4 & 28.9 & 22.4 \\
\hline 31 & --- & -.. & .1 & 9.7 & -.. & 13.5 & -.. & 22.0 & $\ldots$ & 28.6 & 28.3 & -.- \\
\hline
\end{tabular}

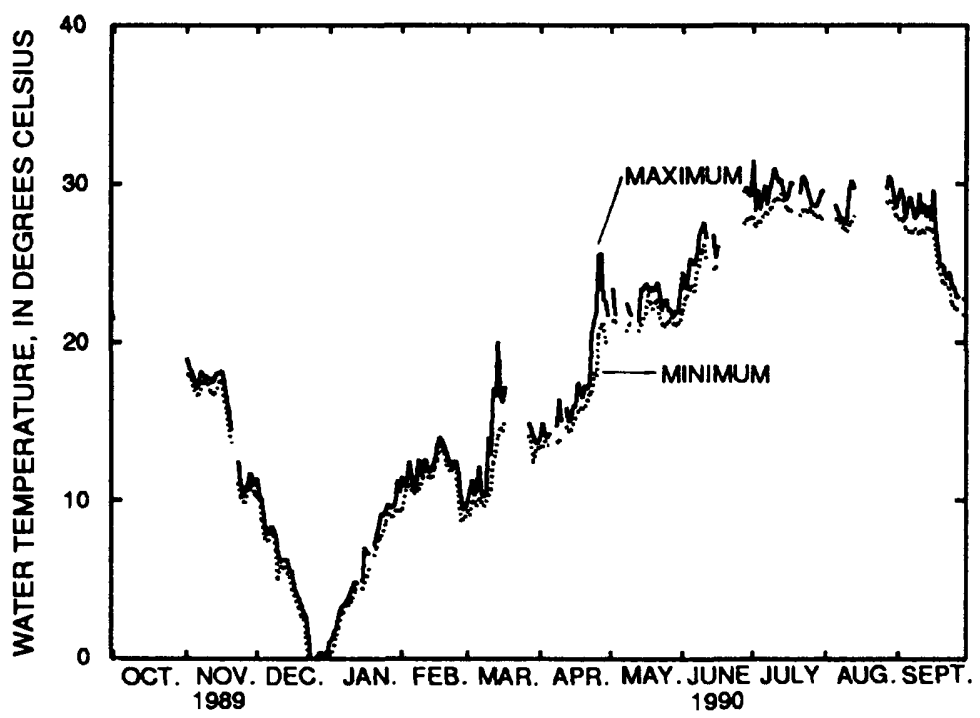


Table 10.--Daily mean values of water temperature, near surface, in water at site 1, Chowan River near Edenhouse,

October 1990 through April 1991

STATION NUMBER AND NAME: 0205365200, Chowan River near Edenhouse

LATITUDE: $36^{\circ} 02^{\prime} 52^{\prime \prime}$ LONGITUDE: $76^{\circ} 41^{\prime} 42^{\prime \prime}$ COUNTY: Bertie

PROBE LOCATION: 20 feet above bottom

[Water temperature, degrees Celsius; ---, no data]

\begin{tabular}{|c|c|c|c|c|c|c|c|}
\hline Day & Oct. & Nov. & Dec. & Jan. & Feb. & Mar. & Apr. \\
\hline 1 & 22.2 & 15.5 & --- & 10.7 & 7.3 & 9.3 & 14.1 \\
\hline 2 & 22.3 & 16.3 & --- & 10.4 & 7.3 & 9.7 & 14.5 \\
\hline 3 & 22.2 & 16.3 & -- & 10.4 & 8.1 & 10.2 & 14.1 \\
\hline 4 & 22.1 & 16.1 & --- & 10.2 & 8.7 & 10.9 & 14.4 \\
\hline 5 & 22.5 & 16.2 & --- & 9.9 & 9.8 & 11.4 & 14.3 \\
\hline 6 & 22.9 & 16.1 & --- & 10.0 & 10.2 & 11.1 & 15.2 \\
\hline 7 & 23.2 & 16.1 & --- & 9.9 & 9.8 & 11.4 & 16.2 \\
\hline 8 & 23.7 & 15.6 & --- & 8.7 & 9.3 & 11.5 & 16.1 \\
\hline 9 & 23.7 & 14.9 & --- & 7.7 & 9.2 & 11.1 & 16.4 \\
\hline 10 & 23.4 & 15.0 & $\cdots$ & 7.7 & 9.4 & 10.9 & 17.7 \\
\hline 11 & 23.3 & 14.6 & --- & 8.1 & 9.0 & 10.4 & 17.7 \\
\hline 12 & 23.5 & 14.0 & $-\cdots$ & 8.4 & 8.7 & 9.9 & $\cdots$ \\
\hline 13 & 23.9 & 13.7 & 10.2 & 8.6 & 8.7 & 9.8 & 17.2 \\
\hline 14 & 24.6 & 13.2 & 10.3 & 8.2 & 9.2 & 9.9 & 16.9 \\
\hline 15 & 24.1 & 13.2 & 10.0 & 8.3 & 9.1 & 9.5 & 17.1 \\
\hline 16 & 23.2 & 12.9 & 10.2 & 8.7 & 7.6 & 9.4 & 17.7 \\
\hline 17 & 22.9 & 12.8 & 10.2 & 8.7 & 6.8 & 9.8 & 18.6 \\
\hline 18 & 22.5 & 12.1 & 10.4 & 8.7 & 7.1 & --. & 18.0 \\
\hline 19 & 21.6 & 11.6 & 11.1 & 8.7 & 7.5 & --. & 17.1 \\
\hline 20 & 20.7 & 11.4 & 11.0 & 8.5 & 8.6 & --- & 14.6 \\
\hline 21 & 20.4 & 11.4 & 11.4 & 7.9 & 9.8 & $--\cdot$ & 13.4 \\
\hline 22 & 20.4 & 11.5 & 11.9 & 7.4 & 10.2 & --- & 13.0 \\
\hline 23 & 20.2 & 11.6 & 12.2 & 6.8 & 9.6 & 12.2 & 13.6 \\
\hline 24 & 20.4 & 11.7 & 12.7 & 6.2 & 9.3 & 12.5 & 15.2 \\
\hline 25 & 20.4 & 11.7 & 11.9 & 6.5 & 8.9 & 14.2 & 14.5 \\
\hline 26 & 18.5 & 12.2 & 11.1 & 6.1 & 9.1 & 13.8 & 15.0 \\
\hline 27 & 16.7 & 12.5 & 10.3 & 6.2 & 8.9 & 13.9 & 15.7 \\
\hline 28 & 16.0 & --- & 9.9 & 6.6 & 8.8 & 14.5 & 17.6 \\
\hline 29 & 15.5 & --- & 9.6 & 6.8 & --- & 15.1 & 20.0 \\
\hline 30 & 15.3 & $\cdots$ & 10.2 & 6.9 & --- & 15.0 & 21.2 \\
\hline 31 & 15.2 & --- & 11.0 & 7.1 & --- & 14.4 & $\cdots$ \\
\hline
\end{tabular}

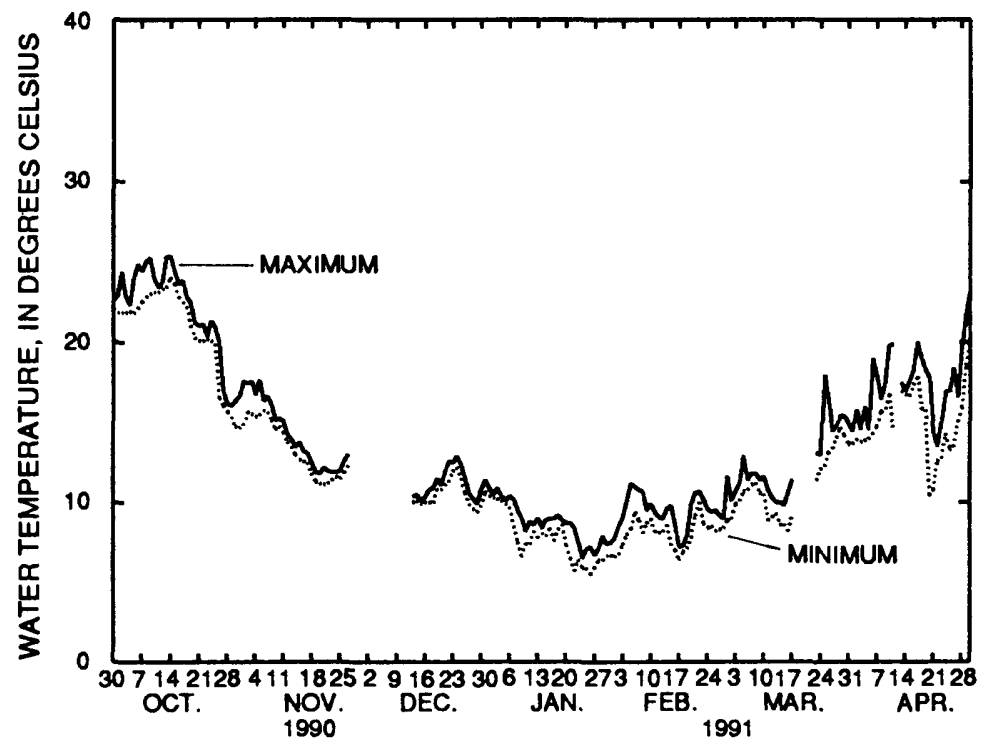


Table 11.--Daily mean values of dissolved-oxygen concentration, near surface, in water at site 1, Chowan River near Edenhouse, October 1989 through September 1990

STATION NUMBER AND NAME: 0205365200, Chowan River near Edenhouse

LATITUDE: $36^{\circ} 02^{\prime} 52^{\prime \prime}$ LONGITUDE: $76^{\circ} 41^{\prime} 42^{\prime \prime}$ COUNTY: Bertie

PROBE LOCATION: 20 feet above bottom

[Dissolved-oxygen concentration, milligrams per liter; ---, no data]

\begin{tabular}{|c|c|c|c|c|c|c|c|c|c|c|c|c|}
\hline Day & Oct. & Nov. & Dec. & Jan & Feb. & Mar. & Apr. & May & June & July & Aug. & Sept. \\
\hline 1 & 7.8 & 8.5 & 11.1 & 12.8 & 9.9 & 11.1 & 9.7 & --- & 8.8 & --. & -.. & 5.7 \\
\hline 2 & -.. & 8.6 & 11.1 & 12.5 & 9.8 & 11.1 & 9.7 & 8.3 & 8.8 & --. & --. & 5.4 \\
\hline 3 & -.. & 8.6 & 11.3 & 12.5 & 9.8 & 11.1 & 9.6 & 8.1 & 8.9 & --- & 4.5 & 5.9 \\
\hline 4 & --- & 8.8 & 11.6 & 12.5 & 9.7 & 11.1 & 9.7 & 7.9 & 8.5 & -.. & ... & 6.1 \\
\hline 5 & --. & 8.8 & 11.7 & 12.4 & 9.9 & 11.2 & 9.7 & -- & 8.5 & --. & 4.3 & 6.1 \\
\hline 6 & --- & 8.9 & 11.7 & 12.3 & 10.0 & 11.0 & --- & --- & 8.7 & --- & 5.0 & 6.7 \\
\hline 7 & --- & 8.8 & 11.7 & 12.2 & 10.0 & 11.3 & --. & $\ldots$ & 8.4 & -.- & 4.6 & 6.1 \\
\hline 8 & --- & 8.9 & 11.8 & 12.2 & 10.0 & 11.4 & 9.8 & 8.1 & 8.4 & -.- & 5.0 & 6.3 \\
\hline 9 & --- & 8.9 & 12.0 & 12.1 & 10.0 & 11.3 & 9.7 & 8.1 & 8.2 & --- & 5.3 & 6.4 \\
\hline 10 & --. & 9.0 & 12.3 & 11.9 & 10.1 & 11.3 & 9.7 & 8.2 & 8.2 & --- & 5.7 & 6.0 \\
\hline 11 & --- & 9.0 & 12.2 & 11.9 & 10.1 & 11.1 & --. & --- & 7.4 & $\ldots$ & 6.2 & 6.4 \\
\hline 12 & --- & 9.1 & 12.2 & 11.6 & 10.1 & 11.1 & 9.5 & -.. & --- & --- & 7.2 & 6.8 \\
\hline 13 & -.. & 9.2 & 12.3 & 11.6 & 10.2 & 11.0 & 9.5 & 8.2 & --- & --- & 8.0 & 6.9 \\
\hline 14 & -.- & 9.1 & 12.2 & --- & 10.3 & 11.0 & 9.4 & 8.2 & 7.3 & --- & $-\cdot$ & 5.6 \\
\hline 15 & $\cdots$ & 9.3 & 12.3 & 11.3 & 10.3 & --- & 8.8 & 8.5 & 7.3 & --- & --- & 6.0 \\
\hline 16 & --- & 9.4 & 12.5 & 11.0 & 10.4 & --- & 8.9 & 8.3 & 7.1 & -- & -.. & 5.3 \\
\hline 17 & --- & 9.4 & 12.5 & 11.0 & 10.3 & --- & 8.9 & 8.2 & --- & -- & $\cdots$ & 6.7 \\
\hline 18 & --- & 9.5 & 12.5 & 11.1 & 10.4 & --- & 9.1 & 8.0 & --- & --. & -.. & 6.7 \\
\hline 19 & --- & 9.8 & 12.6 & --- & 10.1 & -- & 9.2 & 8.1 & --- & -.. & -.. & 7.0 \\
\hline 20 & --- & 10.0 & 12.7 & 11.0 & 10.5 & --- & 9.2 & 8.1 & --- & $--\cdot$ & $\cdots$ & 7.4 \\
\hline 21 & --- & --. & 12.7 & 11.0 & 10.5 & --- & 9.0 & 8.1 & -.- & 8.2 & -- & 7.4 \\
\hline 22 &.-- & --- & 13.2 & 10.9 & 10.5 & --- & 9.0 & 8.1 & --. & 7.9 & -- & 6.9 \\
\hline 23 & --- & 10.9 & 13.6 & 10.8 & 10.5 & --- & 8.9 & 8.3 & -.. & 7.0 & -.. & 7.3 \\
\hline 24 & -.. & 11.1 & -- & 10.7 & 10.5 & --- & 8.9 & 8.3 & --- & 7.7 & -.. & 7.3 \\
\hline 25 & --- & 11.2 & -- & 10.6 & 10.8 & --- & 8.8 & 8.3 & --- & 7.7 & -- & 7.3 \\
\hline 26 & $\ldots$ & 11.3 & 12.9 & 10.5 & 11.3 & $\ldots$ & 8.8 & 8.4 & --- & 7.3 & -.. & 7.4 \\
\hline 27 & --. & 11.3 & 12.8 & 10.5 & 11.3 & --- & 9.0 & 8.4 & --- & 7.0 & 5.2 & 7.6 \\
\hline 28 & $\ldots$ & 11.3 & 12.9 & 10.5 & 11.3 & -- & 8.9 & 8.4 & --- & 6.3 & 5.8 & $\ldots$ \\
\hline 29 & --- & 11.2 & 12.8 & 10.5 & --- & --- & 8.8 & 8.4 & --- & 5.5 & 5.6 & 8.3 \\
\hline 30 & --- & 11.2 & 12.7 & 10.4 & --- & $\cdots$ & 8.6 & 8.5 & --- & 5.4 & 5.5 & 8.4 \\
\hline 31 & -.. & --- & 12.7 & 10.0 & --- & 9.7 & --- & 8.6 & -.- & 5.6 & 5.4 & --- \\
\hline
\end{tabular}

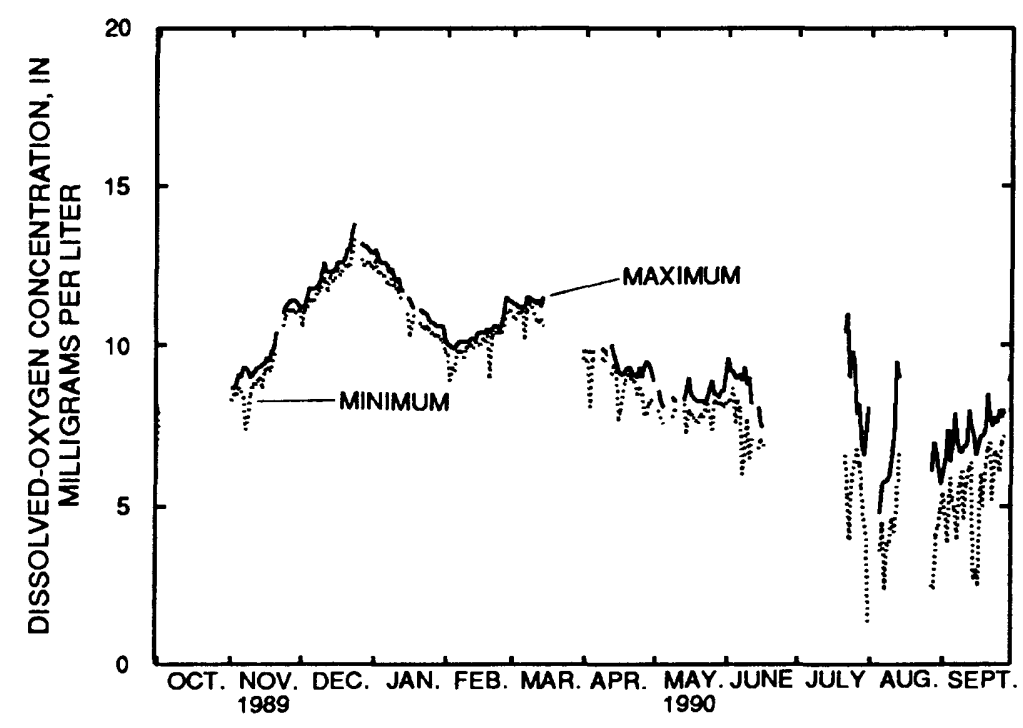


Table 12.--Daily mean values of dissolved-oxygen concentration, near surface, in water at site 1, Cowan River near Edenhouse, October 1990 through April 1991

STATION NUMBER AND NAME: 0205365200 , Chowan River near Edenhouse

LATITUDE: $36^{\circ} 02^{\prime} 52^{\prime \prime}$ LONGITUDE: $76^{\circ} 41^{\prime} 42^{\prime \prime}$ COUNTY: Bertie

PROBE LOCATION: 20 feet above bottom

[Dissolved-oxygen, milligrams per liter; ---, no data]

\begin{tabular}{|c|c|c|c|c|c|c|c|}
\hline Day & Oct. & Nov. & Dec. & Jan. & Feb. & Mar. & Apr. \\
\hline 1 & 8.2 & 9.7 & --- & 11.4 & 11.3 & 10.8 & --- \\
\hline 2 & 8.5 & 9.9 & --- & 11.5 & 11.2 & 10.7 & --- \\
\hline 3 & 8.2 & 9.9 & --- & 11.4 & 11.1 & 10.6 & --. \\
\hline 4 & 8.1 & 9.7 & --- & 11.4 & 11.0 & 10.5 & --- \\
\hline 5 & 8.4 & 9.6 & --- & 11.4 & 10.9 & 10.3 & --- \\
\hline 6 & 8.5 & 9.2 & --- & 11.3 & 10.9 & 10.2 & --- \\
\hline 7 & 8.5 & 9.1 & $-\cdots$ & 11.4 & 10.8 & 10.1 & --- \\
\hline 8 & 8.5 & 9.2 & --- & 11.6 & 10.7 & 10.0 & --. \\
\hline 9 & 8.1 & 9.3 & .-. & 11.6 & 10.7 & 10.0 & --- \\
\hline 10 & 7.7 & --- & --. & 11.7 & 10.6 & 10.0 & --- \\
\hline 11 & 7.8 & --- & --. & 11.7 & 10.6 & 10.0 & --- \\
\hline 12 & 7.9 & --- & --- & 11.6 & 10.7 & 10.1 & --- \\
\hline 13 & 7.8 & --- & 11.8 & 11.5 & 10.7 & 10.2 & -.- \\
\hline 14 & 8.1 & 9.6 & 11.9 & 11.5 & 10.8 & 10.1 & $\cdots$ \\
\hline 15 & 8.1 & --- & 11.9 & 11.6 & 10.8 & 10.2 & -.. \\
\hline 16 & 7.8 & --- & 11.8 & 11.6 & 11.1 & 10.2 & --- \\
\hline 17 & 7.9 & --. & 11.8 & 11.5 & ... & 10.2 & --- \\
\hline 18 & 8.1 & --- & 11.8 & 11.4 & -.. & --- & --- \\
\hline 19 & 8.3 & --- & 11.7 & 11.2 & -.. & --- & --- \\
\hline 20 & 8.4 & $\cdots$ & 11.7 & 11.1 & --. & -- & -.. \\
\hline 21 & 8.6 & --- & 11.6 & 11.0 & --- & -.. & ... \\
\hline 22 & 8.6 & --- & 11.6 & 11.1 & --- & --. & --- \\
\hline 23 & 8.6 & --- & 11.5 & 11.2 & -.. & --- & --- \\
\hline 24 & --- & --- & 11.3 & 11.3 & -.. & --- & --- \\
\hline 25 & $\cdots$ & --- & 11.2 & 11.4 & --- & --- & --- \\
\hline 26 & $\cdots$ & --- & 11.3 & 11.4 & -.. & --- & --. \\
\hline 27 & 9.4 & $\cdots$ & 11.4 & 11.3 & 10.9 & --- &.-- \\
\hline 28 & 9.4 & $\cdots$ & 11.5 & 11.3 & 10.9 & --- & -- \\
\hline 29 & 9.6 & --- & 11.6 & 11.2 & --- & --. & --- \\
\hline 30 & 9.6 & --- & 11.5 & 11.1 & $\cdots$ & --- & --- \\
\hline 31 & 9.6 & --. & 11.5 & 11.2 & --- & -.- & --. \\
\hline
\end{tabular}

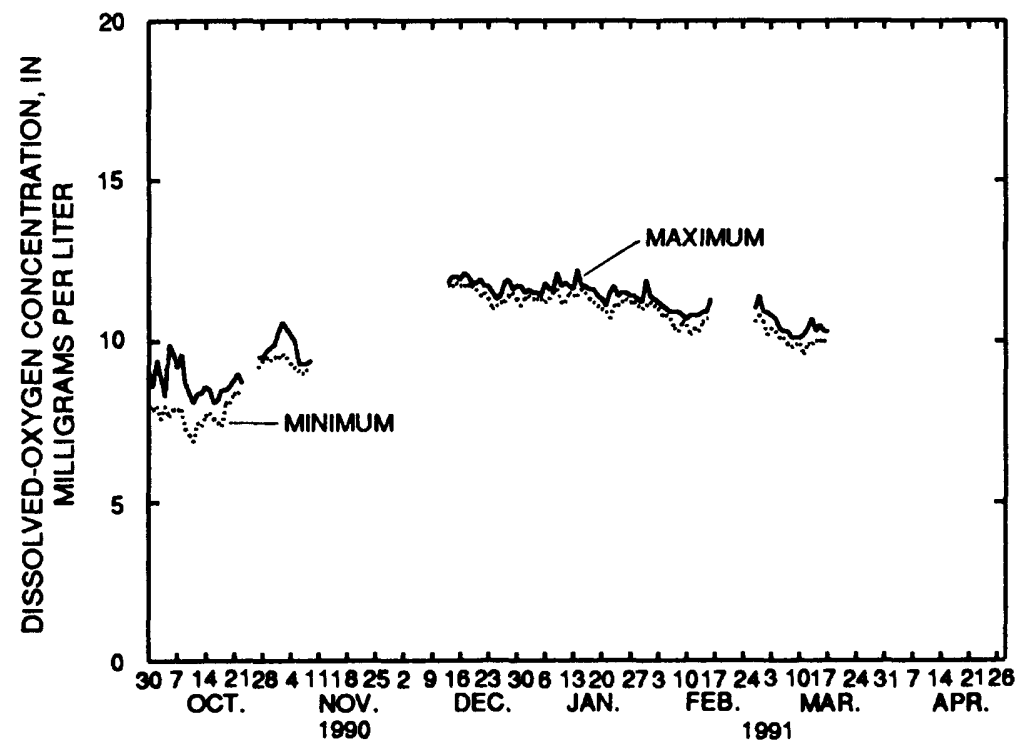


Table 13.--Daily mean values of dissolved-oxygen concentration, mid-depth, in water at site 1, Chowan River near Edenhouse, October 1989 through September 1990

STATION NUMBER AND NAME: 0205365200, Chowan River near Edenhouse LATITUDE: $36^{\circ} 02^{\prime} 52^{\prime \prime}$ LONGITUDE: $76^{\circ} 41^{\prime} 42^{\prime \prime}$ COUNTY: Bertie

PROBE LOCATION: 12 feet above bottom

[Dissolved-oxygen concentration, milligrams per liter; ---, no data]

\begin{tabular}{|c|c|c|c|c|c|c|c|c|c|c|c|c|}
\hline Day & Oct. & Nov. & Dec. & Jan & Feb. & Mar. & Apr. & May & June & July & Aug. & Sept. \\
\hline 1 & 3.4 & 7.7 & 11.3 & 14.1 & 9.5 & 10.8 & 9.5 & $\cdots$ & 8.2 & $\ldots$ & -.- & -.. \\
\hline 2 & --- & 11.5 & 11.3 & 12.8 & 9.8 & 9.8 & 9.9 & 7.0 & 8.5 & -.. & --- & --- \\
\hline 3 & -.- & 12.8 & 12.9 & 12.5 & 9.9 & 9.6 & 10.1 & 7.9 & 8.9 & --- & 5.2 & --- \\
\hline 4 & --- & 12.6 & 12.9 & 12.6 & 10.0 & 10.6 & 10.3 & 7.2 & 8.2 & $\cdots$ & --- & -.- \\
\hline 5 & -- & -.- & 12.7 & 12.4 & 10.3 & 11.0 & 9.8 & --. & 8.6 & --- & 4.6 & --- \\
\hline 6 & -.- & --- & 12.4 & 12.1 & 9.4 & 10.2 & --. & --- & 8.5 & $\ldots$ & 5.0 & $\ldots$ \\
\hline 7 & --- & --- & 12.6 & 11.8 & 9.5 & 11.6 & --- & --- & 8.9 & ... & 5.1 & --- \\
\hline 8 & --. & --- & 13.4 & 12.2 & 8.9 & 11.6 & 9.7 & 7.2 & 8.1 & $\ldots$ & 4.8 & --- \\
\hline 9 & --- & --- & 13.6 & 11.9 & 9.6 & 11.2 & 9.7 & 7.7 & 8.2 & --- & 4.8 & --- \\
\hline 10 & $\cdots$ & -.. & 13.6 & 12.0 & 10.6 & 11.2 & 9.8 & 8.9 & 7.3 & --- & 5.0 & --- \\
\hline 11 & $\ldots$ & --. & 13.0 & 11.7 & 10.3 & 10.8 & --- & --. & 7.8 & --. & 5.3 & --. \\
\hline 12 & -.. & -.. & 12.7 & 11.7 & 9.8 & 10.8 & 9.5 & --. & --- & --- & 5.5 & --- \\
\hline 13 & -.. & --- & 13.6 & 11.7 & 10.4 & 10.7 & 10.4 & 8.4 & --- & $\ldots$ & 5.6 & --- \\
\hline 14 & ... & $\ldots$ & 12.7 & --- & 10.1 & 10.7 & 10.5 & 8.1 & 6.6 & $\cdots$ & --- & --- \\
\hline 15 & --- & --- & 12.8 & 10.8 & 9.6 & --- & 8.8 & 7.9 & 7.9 & -- & --. & --- \\
\hline 16 & -.- & --. & 13.5 & 10.5 & 10.4 & -.- & 8.8 & 7.6 & 7.4 & --- & -.- & --- \\
\hline 17 & --- & --- & 12.6 & 10.3 & 10.2 & -.- & 8.7 & 8.0 & -.. & --- & -.. & $\ldots$ \\
\hline 18 & --. & --- & 11.6 & 10.9 & 10.5 & --. & 9.9 & 6.9 & --. & $\ldots$ & ... & --. \\
\hline 19 & --- & --- & 12.3 & --- & 9.2 & --- & 10.0 & 6.8 & $\ldots$ & --. & $\ldots$ & -.. \\
\hline 20 & -- & $\cdots$ & 13.4 & 10.5 & 10.5 & -- & 9.4 & 7.2 & --- & --- & --- & --- \\
\hline 21 & --- & --. & 12.1 & 10.7 & 10.6 & -.- & 8.9 & 7.2 & --- & 8.7 & --- & $\ldots$ \\
\hline 22 & --- & $\ldots$ & 14.2 & 9.8 & 9.8 & $\cdots$ & 9.0 & 8.1 & $\cdots$ & 8.1 & $\cdots$ & -.- \\
\hline 23 & --- & 13.2 & 14.7 & 9.4 & 9.9 & $\ldots$ & 7.9 & 8.0 & -- & 7.8 & -.- & -.. \\
\hline 24 & --- & 12.1 & 14.6 & 9.6 & 10.1 & $\cdots$ & 7.5 & 7.5 & $\cdots$ & 7.7 & --- & -.- \\
\hline 25 & --. & 11.7 & 13.9 & 10.3 & 10.7 & --- & 7.3 & 7.7 & --. & 8.1 & --- & --- \\
\hline 26 & --- & 12.1 & 13.8 & 10.2 & 10.9 & --. & 6.7 & 8.2 & -- & 7.8 & --- & --- \\
\hline 27 & --- & 11.5 & 13.7 & 9.5 & 10.2 &.-- & 6.3 & 8.2 & $\ldots$ & 7.5 & -.. & -.. \\
\hline 28 & $\ldots$ & 11.4 & 13.6 & 9.0 & 10.6 & --- & 7.0 & 8.6 & --- & 6.8 & --- & --- \\
\hline 29 & --- & 12.6 & 13.4 & 9.5 & --. & --- & 6.8 & 8.1 & -- & 6.2 & --- & 8.1 \\
\hline 30 & --- & 11.6 & 12.9 & 10.2 & --- & -- & 5.3 & 8.4 & --- & 6.1 & --- & 8.1 \\
\hline 31 & --- & -- & 12.9 & 10.0 & --- & 10.1 & --- & 8.3 & --- & 6.8 & --- & --- \\
\hline
\end{tabular}

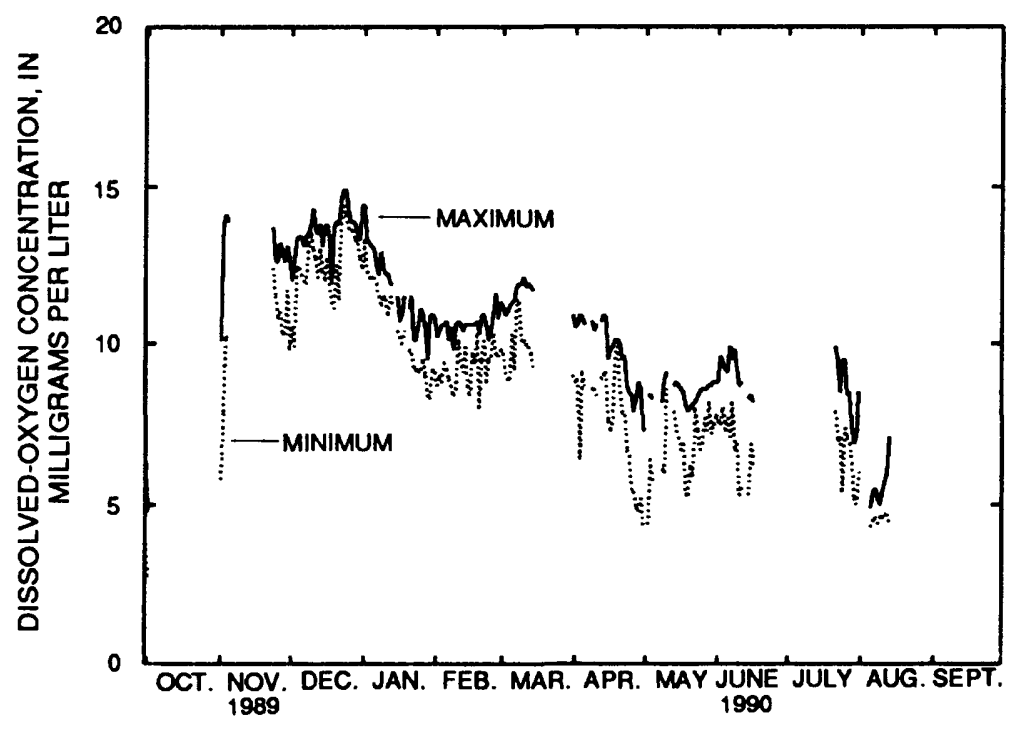


Table 14.--Daily mean values of dissolved-oxygen concentration, mid-depth, in water at site 1, Chowan River near Edenhouse, October 1990 through April 1991

STATION NUMBER AND NAME: 0205365200, Chowan River near Edenhouse LATITUDE: $36^{\circ} 02^{\prime} 52^{\prime \prime}$ LONGITUDE: $76^{\circ} 41^{\prime} 42^{\prime \prime}$ COUNTY: Bertie PROBE LOCATION: 12 feet above bottom

[Dissolved-oxygen concentration, milligrams per liter; ---, no data]

\begin{tabular}{|c|c|c|c|c|c|c|c|}
\hline Day & Oct. & Nov. & Dec. & Jan. & Feb. & Mar. & Apr. \\
\hline 1 & 8.0 & 9.4 & --- & --. & 11.9 & -.- & $\cdots$ \\
\hline 2 & 8.1 & 9.4 & -.- & -.- & 11.8 & -..- & -.- \\
\hline 3 & 8.2 & 9.4 & --- & -- & 11.8 & --- & -.- \\
\hline 4 & 8.1 & 9.4 & --- & --- & 11.7 & --- & --. \\
\hline 5 & 8.0 & 9.3 & -.. & --. & 11.7 & --. & --- \\
\hline 6 & --. & 9.1 & --- & --. & 11.6 & -.. & --- \\
\hline 7 & -.. & 9.0 & --- & --- & 11.5 & -- & $\ldots$ \\
\hline 8 & --. & 9.1 & --. & -.. & 11.5 & -- & -.. \\
\hline 9 & --- & 9.2 & --- & -- & 11.5 & --- & --- \\
\hline 10 & --- & 9.2 & --. & --- & 11.4 & --. & --- \\
\hline 11 & --- & 9.3 & $\ldots$ & --- & --- & --- & --- \\
\hline 12 & -- & 9.4 & --- & -- & -- & --- & --- \\
\hline 13 & --- & 9.5 & 11.5 & --- & --- & --- & 8.1 \\
\hline 14 & --- & 9.5 & 11.6 & --- & -.- & --- & 8.1 \\
\hline 15 & --- & 9.7 & 11.6 & 11.9 & $\cdots$ & --- & 8.1 \\
\hline 16 & --- & 10.1 & 11.7 & 11.9 & $\ldots$ & --. & 8.2 \\
\hline 17 & --- & --- & 11.7 & 11.9 & --. & --. & 8.2 \\
\hline 18 & -.. & -- & 11.7 & 11.8 & --. & --. & 8.2 \\
\hline 19 & --. & --. & 11.6 & 11.6 & .-. & --.- & 8.3 \\
\hline 20 & --- & $\cdots$ & 11.6 & 11.5 & --- & --- & 8.5 \\
\hline 21 & 8.5 & $\ldots$ & 11.5 & 11.4 & $\ldots$ & --- & 8.6 \\
\hline 22 & 8.5 & -.. & 11.5 & 11.6 & $\ldots$ & --- & 8.8 \\
\hline 23 & 8.6 & $\cdots$ & 11.5 & 11.7 & -.- & ... & 8.8 \\
\hline 24 & 8.5 & $\ldots$ & 11.3 & 11.8 & -.. & $\cdots$ & 8.7 \\
\hline 25 & 8.5 & --- & 11.2 & 11.9 & --- & --- & 8.8 \\
\hline 26 & 9.0 & $\cdots$ & 11.3 & 11.9 & --. & $\cdots$ & 8.8 \\
\hline 27 & 9.2 & -.- & 11.3 & 11.9 & --- & $\therefore$ & 8.9 \\
\hline 28 & 9.3 & -- & -- & 11.9 & --- & $\cdots$ & 8.7 \\
\hline 29 & 9.4 & $\cdots$ & --- & 11.8 & --. & --- & 8.8 \\
\hline 30 & 9.4 & -.- & --. & 11.7 & --- & $\ldots$ & 8.9 \\
\hline 31 & 9.4 & --- & -.. & 11.8 & --- & --- & --- \\
\hline
\end{tabular}

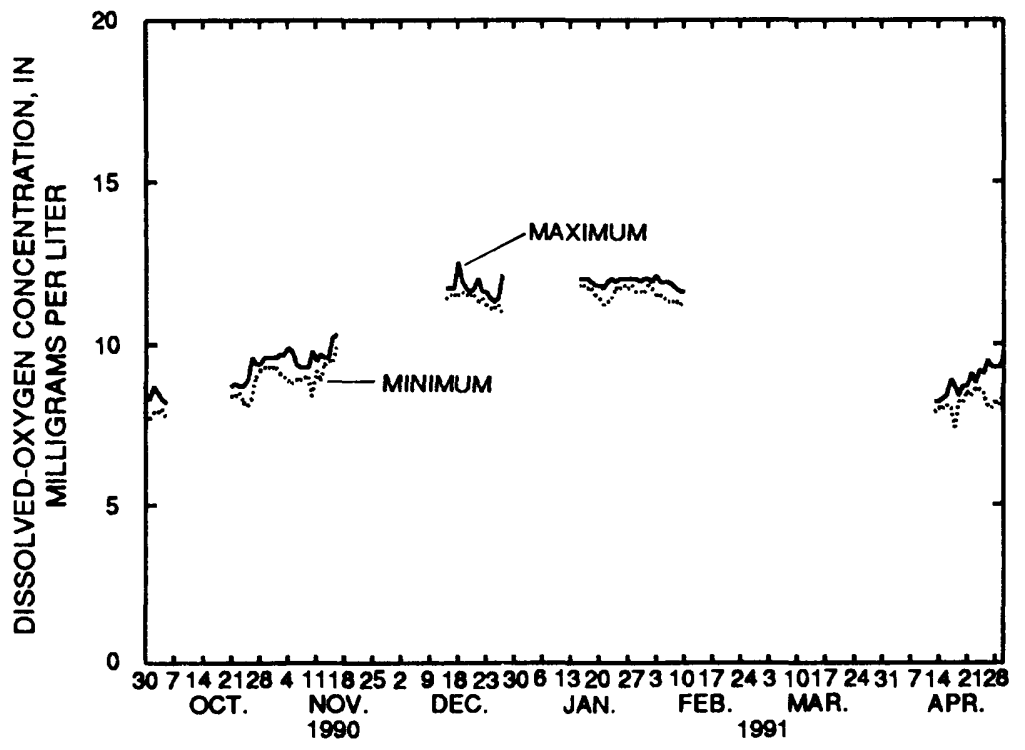


Table 15.--Daily mean values of dissolved-oxygen concentration, near bottom, in water at site 1, Chowan River near Edenhouse, October 1989 through September 1990

STATION NUMBER AND NAME: 0205365200, Chowan River near Edenhouse

LATITUDE: $36^{\circ} 02^{\prime} 52^{\prime \prime}$ LONGITUDE: $76^{\circ} 41^{\prime} 42^{\prime \prime}$ COUNTY: Bertie

PROBE LOCATION: 5 feet above bottom

[Dissolved-oxygen concentration, milligrams per liter; ---, no data]

\begin{tabular}{|c|c|c|c|c|c|c|c|c|c|c|c|c|}
\hline Day & Oct. & Nov. & Dec. & Jan & Feb. & Mar. & Apr. & May & June & July & Aug. & Sept. \\
\hline 1 & 7.9 & 8.6 & 11.6 & 13.5 & 9.5 & 11.0 & 9.3 & --. & 8.5 & 7.1 & --- & 5.7 \\
\hline 2 & --- & 8.5 & 11.6 & 13.2 & 9.7 & 10.9 & 9.4 & 7.6 & 8.0 & 7.9 & --- & 4.9 \\
\hline 3 & --- & 8.7 & 11.7 & 13.1 & 9.5 & 10.9 & 9.5 & 7.6 & 8.4 & 7.8 & 4.8 & 4.9 \\
\hline 4 & -.. & 8.7 & 12.1 & 13.0 & 9.4 & 11.0 & 9.7 & 7.9 & 8.6 & 8.1 & --. & 5.9 \\
\hline 5 & $\cdots$ & 8.9 & 12.1 & 13.0 & 9.6 & 11.0 & 9.7 & --- & 8.4 & 7.9 & 4.5 & 5.6 \\
\hline 6 & $\cdots$ & 8.8 & 12.1 & 12.8 & 9.5 & 10.7 & --- & --- & 8.2 & 7.2 & 5.2 & 6.0 \\
\hline 7 & $\cdots$ & 8.8 & 12.0 & 12.6 & 9.5 & 11.1 & -- & --- & 8.3 & 6.9 & 5.2 & 5.4 \\
\hline 8 & $\cdots$ & 8.5 & 12.1 & 12.5 & 9.8 & 11.4 & 9.8 & 8.1 & 7.8 & 7.0 & 5.1 & 5.8 \\
\hline 9 & $\cdots$ & 8.6 & 12.3 & 12.4 & 9.9 & 11.4 & 9.7 & 8.3 & 7.4 & 7.6 & 5.3 & 6.0 \\
\hline 10 & --. & 9.0 & 12.6 & 12.0 & 10.0 & 11.3 & 9.7 & 8.8 & 7.2 & 7.6 & 5.0 & 6.0 \\
\hline 11 & -- & 8.9 & 12.5 & 14.2 & 10.1 & 11.1 & --- & --. & 8.4 & 7.1 & 4.9 & 5.8 \\
\hline 12 & $\cdots$ & 9.0 & 12.4 & 14.5 & 10.0 & 11.0 & 10.1 & --- & --- & 7.1 & 5.2 & 5.7 \\
\hline 13 & $\ldots$ & 9.0 & 12.5 & 12.6 & 10.0 & 10.9 & 10.1 & 8.4 & --- & 7.1 & 5.0 & 5.9 \\
\hline 14 & --- & 9.0 & 12.4 & --- & 10.1 & 10.7 & 9.8 & 8.3 & 8.5 & 7.2 & -.- & 5.6 \\
\hline 15 & --- & 9.0 & 12.4 & 9.0 & 10.2 & --- & 9.6 & 7.9 & 8.7 & 7.4 & --- & 6.3 \\
\hline 16 & --- & 9.3 & 12.6 & 8.9 & 10.3 & --- & 9.8 & 8.0 & 8.6 & 7.0 & --- & 6.0 \\
\hline 17 & --- & 9.4 & 12.6 & 8.9 & 10.3 & --- & 10.2 & 8.1 & --- & 7.0 & --- & 6.7 \\
\hline 18 & --- & 9.5 & 12.5 & 9.1 & 10.3 & --- & 10.4 & 8.1 & --- & 7.0 & --- & 6.6 \\
\hline 19 & $-\cdots$ & 9.7 & 12.7 & $\cdots$ & 10.2 & --- & 10.3 & 8.1 & --. & --. & --- & 6.8 \\
\hline 20 & --- & 10.0 & 12.7 & 9.4 & 10.3 & -- & 10.0 & 8.0 & --- & --. & --- & 7.3 \\
\hline 21 & --- & $\cdots$ & 12.6 & 9.6 & 10.4 & $\cdots$ & 9.9 & 8.1 & --- & 6.3 & --- & 7.3 \\
\hline 22 & --- & --- & 13.1 & 9.6 & 10.3 & --- & 9.8 & 8.1 & --- & 6.7 & $\cdots$ & 7.4 \\
\hline 23 & --- & 10.9 & 13.5 & 9.7 & 10.1 & -- & 9.5 & 8.6 & --- & 5.5 & --- & 7.5 \\
\hline 24 & --- & 11.2 & 13.8 & 9.8 & 10.5 & --- & 9.2 & 8.6 & -.. & 6.1 & --. & 7.5 \\
\hline 25 & --- & 11.2 & 14.1 & 9.9 & 10.8 & -- & 9.1 & 8.5 & --- & 6.9 & --- & 7.5 \\
\hline 26 & --- & 11.4 & 14.1 & 10.1 & 11.1 & -- & 8.8 & 8.9 & --- & 7.5 & -.. & 7.7 \\
\hline 27 & --- & 11.3 & 13.9 & 10.2 & 11.0 & -.. & 8.5 & 8.8 & 7.1 & 7.2 & 4.8 & 7.7 \\
\hline 28 & $\cdots$ & 11.5 & 13.9 & 10.4 & 11.0 & --- & 7.9 & 8.8 & 7.5 & 6.5 & 4.7 & --- \\
\hline 29 & --- & 11.7 & 13.7 & 10.4 & --. & --- & 8.0 & 8.8 & 7.2 & 5.4 & 4.6 & 8.0 \\
\hline 30 & --- & 11.7 & 13.6 & 10.0 & --- & --- & 7.2 & 8.8 & 7.5 & 5.0 & 5.6 & 8.2 \\
\hline 31 & --- & $\cdots$ & 13.6 & 9.4 & --- & 9.2 & -.. & 8.6 & --.- & 5.7 & 5.6 & 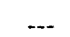 \\
\hline
\end{tabular}

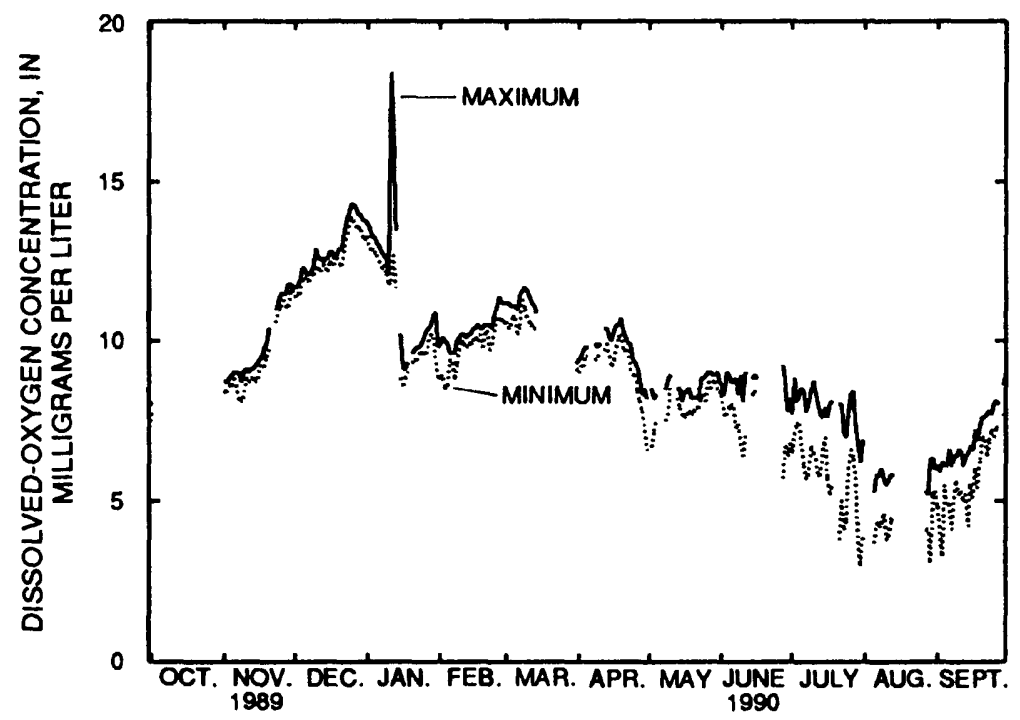


Table 16.--Daily mean values of dissolved-oxygen concentration, near bottom, in water at site 1, Chowan River near Edenhouse, October 1990 through April 1991

STATION NUMBER AND NAME: 0205365200, Chowan River near Edenhouse

LATITUDE: $36^{\circ} 02^{\prime} 52^{\prime \prime}$ LONGITUDE: $76^{\circ} 41^{\prime} 42^{\prime \prime}$ COUNTY: Bertie

PROBE LOCATION: 5 feet above bottom

[Dissolved-oxygen concentration, milligrams per liter; --., no data]

\begin{tabular}{|c|c|c|c|c|c|c|c|}
\hline Day & Oct. & Nov. & Dec. & Jan. & Feb. & Mar. & Apr. \\
\hline 1 & 8.2 & 7.8 & -.. & 11.3 & 11.2 & 11.0 & -.- \\
\hline 2 & 8.4 & 7.9 & --- & 11.3 & 11.2 & 11.1 & $\ldots$ \\
\hline 3 & 8.0 & 7.9 & -- & 11.3 & 11.1 & 11.0 & -.. \\
\hline 4 & 8.2 & 7.9 & --. & 11.2 & 10.9 & 10.9 & $-\cdots$ \\
\hline 5 & 8.0 & 8.0 & ... & 11.3 & 10.8 & 10.9 & -- \\
\hline 6 & 7.7 & 8.2 & --- & 11.2 & 10.6 & 10.9 & -- \\
\hline 7 & 7.8 & 8.4 & --- & 11.3 & 10.5 & 10.9 & ... \\
\hline 8 & 7.2 & 8.7 & --- & 11.5 & 10.7 & 10.9 & -.. \\
\hline 9 & 6.7 & 8.9 & -- & 11.7 & 10.6 & 10.9 & $\cdots$ \\
\hline 10 & 6.4 & 8.8 & --- & 11.7 & 10.4 & 11.0 & --- \\
\hline 11 & $\ldots$ & 9.0 & --. & 11.8 & 10.4 & 11.1 & --- \\
\hline 12 & --- & 9.2 & -.. & 11.6 & 10.5 & 11.3 & -.- \\
\hline 13 & --- & 9.4 & 11.5 & 11.6 & 10.6 & 11.5 & --- \\
\hline 14 & -.- & 9.5 & 11.6 & 10.7 & 10.7 & 11.5 & --. \\
\hline 15 & --- & 9.4 & 11.5 & 11.6 & 10.7 & 11.6 & -.. \\
\hline 16 & $\ldots$ & 8.8 & 11.5 & 12.4 & 11.0 & 11.8 & $\cdots$ \\
\hline 17 & --- & 8.9 & 11.5 & 11.8 & --- & 11.8 & -- \\
\hline 18 & --- & 9.1 & 11.6 & 11.6 & --- & --. & --. \\
\hline 19 & --. & 9.2 & 11.4 & 11.3 & --- & --. & --. \\
\hline 20 & 9.2 & 9.3 & 11.4 & 11.1 & --- & --. & $\cdots$ \\
\hline 21 & 9.0 & 9.3 & 11.3 & 10.9 & --- & --- & 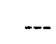 \\
\hline 22 & 8.5 & 9.2 & 11.2 & 11.1 & --. & --. & -- \\
\hline 23 & 8.3 & 9.2 & --- & 11.2 & -.- & --- & -.. \\
\hline 24 & 8.4 & 9.4 & 11.1 & 11.3 & -.- & --- & $\ldots$ \\
\hline 25 & 6.4 & 9.4 & 10.9 & 11.3 & --- & --- & --- \\
\hline 26 & 6.4 & 9.3 & 11.0 & 11.3 & 10.8 & -.- & ... \\
\hline 27 & 6.8 & 9.3 & 11.2 & 11.4 & 10.9 & --. & -.. \\
\hline 28 & 6.9 & -- & 11.4 & 11.4 & 11.0 & --. & -- \\
\hline 29 & 7.3 & --. & 11.4 & 11.3 & --- & --- & -. \\
\hline 30 & 7.6 & --- & 11.4 & 11.1 & --. & --- & --- \\
\hline 31 & 8.6 & --. & 11.3 & 11.2 & --- & --- & --- \\
\hline
\end{tabular}

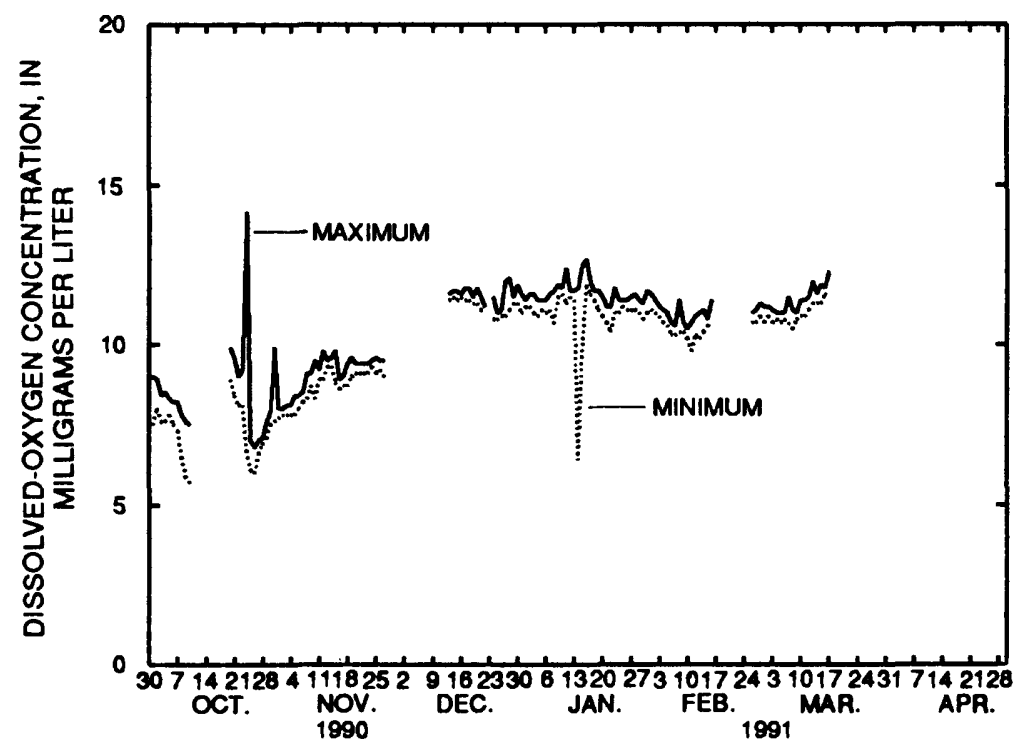


Table 17.--Daily mean values of specific conductance, near surface, in water at site 2, Roanoke River at light 1, November 1990 through May 1991

STATION NUMBER AND LOCATION: 0208411443, Roanoke River at light 1 LATITUDE: $35^{\circ} 57^{\prime} 17^{\prime \prime}$ LONGITUDE: $76^{\circ} 39^{\prime} 52^{\prime \prime}$ COUNTY: Washington PROBE LOCATION: 10 feet above bottom

[Specific conductance, microsiemens per centimeter at 25 degrees Celsius; ---, no data]

\begin{tabular}{|c|c|c|c|c|c|c|c|}
\hline Day & Nov. & Dec. & Jan. & Feb. & Mar. & Apr. & May \\
\hline 1 & --- & $\cdots$ & --- & 95 & 125 & 104 & 105 \\
\hline 2 & --- & --- & --- & 102 & 128 & 92 & 113 \\
\hline 3 & --- & --- & --- & 102 & 125 & 100 & 112 \\
\hline 4 & -- & -- & -- & 103 & 140 & 96 & 104 \\
\hline 5 & -- & --- & --- & 102 & 131 & 101 & 109 \\
\hline 6 & $\ldots$ & --- & --- & 99 & 128 & 104 & 117 \\
\hline 7 & --- & --- & $\cdots$ & 99 & 139 & 103 & 117 \\
\hline 8 & --- & --- & $\cdots$ & 95 & 119 & 103 & --- \\
\hline 9 & --. & --- & -- & 94 & 98 & 104 & $\ldots$ \\
\hline 10 & $\cdots$ & --- & -- & 93 & 98 & 105 & --- \\
\hline 11 & --- & -.. & $\cdots$ & 100 & 97 & 101 & -.. \\
\hline 12 & --- & --- & -- & 96 & 91 & 102 & $\cdots$ \\
\hline 13 & $\cdots$ & $\cdots$ & -- & 99 & 94 & 109 & --- \\
\hline 14 & --- & --- & -.. & 100 & 93 & 105 & --- \\
\hline 15 & -- & --- & $\cdots$ & 98 & 90 & 100 & --. \\
\hline 16 & 89 & --- & $\cdots$ & 104 & 90 & 103 & --. \\
\hline 17 & 87 & --- & $\cdots$ & 115 & 93 & 102 & -.. \\
\hline 18 & 85 & --. & 103 & 105 & 94 & 105 & --. \\
\hline 19 & 83 & -- & 101 & 108 & 94 & 109 & -.. \\
\hline 20 & 87 & --- & 108 & 109 & 86 & 109 & --- \\
\hline 21 & 83 & $\cdots$ & 108 & 111 & 86 & 105 & --. \\
\hline 22 & 91 & $\cdots$ & 96 & 111 & 92 & 105 & --. \\
\hline 23 & 94 & $\cdots$ & 98 & 105 & 100 & 105 & -.- \\
\hline 24 & 94 & -.. & 104 & 117 & 103 & 107 & --- \\
\hline 25 & 92 & -- & 105 & 145 & 103 & 105 & --- \\
\hline 26 & 91 & --- & 102 & 121 & 104 & 105 & --. \\
\hline 27 & 89 & $\cdots$ & 105 & 110 & 104 & 107 & --- \\
\hline 28 & $\cdots$ & -- & 106 & 116 & 110 & 108 & -- \\
\hline 29 & -- & $\cdots$ & 106 & -- & 123 & 105 & $\cdots$ \\
\hline 30 & $\cdots$ & --. & 105 & --- & 119 & 102 & --- \\
\hline 31 & -- & --. & 103 & $\cdots$ & 109 & --- & -- \\
\hline
\end{tabular}

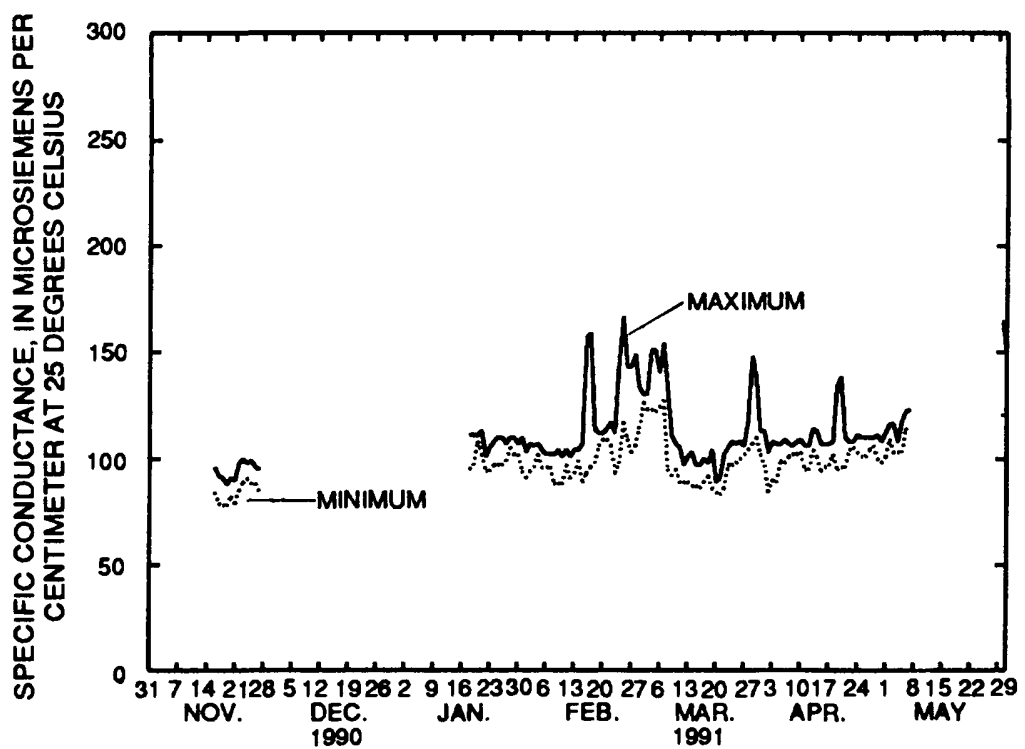


Table 18.--Daily mean values of salinity concentration, near surface, in water at site 2, Roanoke River at light 1 , November 1990 through May 1991

STATION NUMBER AND NAME: 208411443, Roanoke River at light 1 LATITUDE: 35'57'17" LONGITUDE: 76³9'52" COUNTY: Washington PROBE LOCATION: 10 feet above bottom

[Salinity concentration, parts per thousand; ---, no data]

\begin{tabular}{|c|c|c|c|c|c|c|c|}
\hline Day & Nov. & Dec. & Jan. & Feb. & Mar. & Apr. & May \\
\hline 1 & --- & --. & --- & 0.04 & 0.05 & 0.04 & 0.04 \\
\hline 2 & --- & --- & --- & .04 & .05 & .04 & .05 \\
\hline 3 & --- & --- & --. & .04 & .05 & .04 & .04 \\
\hline 4 & --- & --- & --- & .04 & .06 & .04 & .04 \\
\hline 5 & $\ldots$ & --. & --- & .04 & .05 & .04 & .04 \\
\hline 6 & $\ldots$ & --- & --- & .04 & .05 & .04 & .05 \\
\hline 7 & --- & --- & ... & .04 & .06 & .04 & .05 \\
\hline 8 & $\ldots$ & -.- & --- & .04 & .05 & .04 & -.- \\
\hline 9 & --- & --- & --- & .04 & .04 & .04 & --- \\
\hline 10 & --- & --- & --- & .04 & .04 & .04 & --- \\
\hline 11 & --- & -... & -.- & .04 & .04 & .04 & -.- \\
\hline 12 & --- & $\cdots$ &.-- & .04 & .04 & .04 & -.- \\
\hline 13 & $\ldots$ & --- & --- & .04 & .04 & .04 & -.. \\
\hline 14 & --- & --- & $\cdots$ & .04 & .04 & .04 & --- \\
\hline 15 & -- & --- & $\cdots$ & .04 & .04 & .04 & --- \\
\hline 16 & 0.04 & --- & -.- & .04 & .04 & .04 & -.. \\
\hline 17 & .03 & --- & --- & .05 & .04 & .04 & $\ldots$ \\
\hline 18 & .03 & -.- & 0.04 & .04 & .04 & .04 & -.. \\
\hline 19 & .03 & --- & .04 & .04 & .04 & .04 & --- \\
\hline 20 & .03 & --- & .04 & .04 & .03 & .04 & ..- \\
\hline 21 & .03 & --- & .04 & .04 & .03 & .04 & --- \\
\hline 22 & .04 & --- & .04 & .04 & .04 & .04 & $-\cdots$ \\
\hline 23 & .04 & --- & .04 & .04 & .04 & .04 & -- \\
\hline 24 & .04 & -.. & .04 & .05 & .04 & .04 & -.. \\
\hline 25 & .04 & --. & .04 & .06 & .04 & .04 & $\cdots$ \\
\hline 26 & .04 & --- & .04 & .05 & .04 & .04 & $\cdots$ \\
\hline 27 & .04 & --. & .04 & .04 & .04 & .04 & --- \\
\hline 28 & --. & --- & .04 & .05 & .04 & .04 & $-\cdots$ \\
\hline 29 & --- & --- & .04 & --- & .05 & .04 & --- \\
\hline 30 & --- & --- & .04 & --- & .05 & .04 & --. \\
\hline 31 & $\cdots$ & $\cdots$ & .04 & --- & .04 & --- & $\cdots$ \\
\hline
\end{tabular}

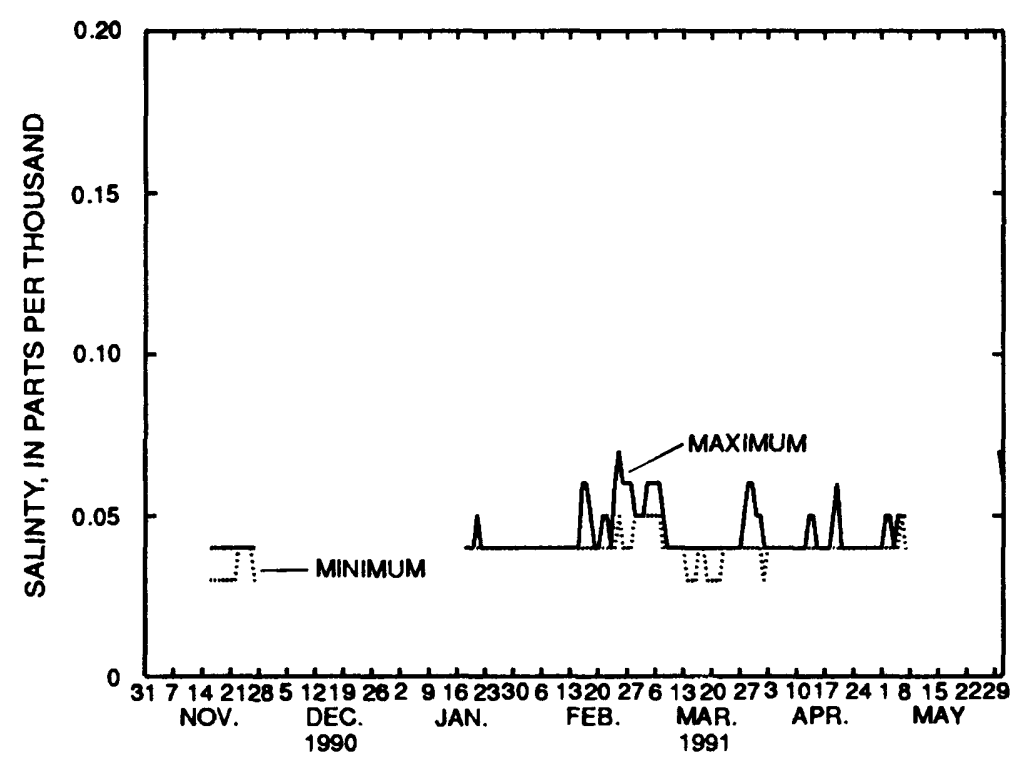


Table 19.--Daily mean values of specific conductance, near bottom, in water at site 2, Roanoke River at light 1 , November 1990 through May 1991

STATION NUMBER AND NAME: 0208411443, Roanoke River at light I

LATITUDE: $35^{\circ} 57^{\prime} 17^{\prime \prime}$ LONGITUDE: 76² $39^{\prime} 52^{\prime \prime}$. COUNTY: Washington PROBE LOCATION: 2 feet above bottom

[Specific conductance, microsiemens per centimeter at 25 degrees Celsius; ---, no data]

\begin{tabular}{|c|c|c|c|c|c|c|c|}
\hline Day & Nov. & Dec. & Jan. & Feb. & Mar. & Apr. & May \\
\hline 1 & --- & --- & --. & 96 & 132 & 101 & 108 \\
\hline 2 & --- & --- & --. & 104 & 128 & 92 & 111 \\
\hline 3 & --- & --- & --- & 103 & 126 & 99 & 111 \\
\hline 4 & ... & --- & --- & 103 & 139 & 95 & 104 \\
\hline 5 & --- & --- & --- & I02 & 131 & 99 & 109 \\
\hline 6 & --- & -.. & --. & 100 & 129 & 103 & 116 \\
\hline 7 & --- & --- & -.. & 100 & 138 & 101 & 117 \\
\hline 8 & --- & $\ldots$ & --- & 95 & 120 & 101 & --- \\
\hline 9 & $\cdots$ & -.- & --- & 95 & 99 & 101 & --- \\
\hline 10 & --- & --- & --- & 94 & 100 & 103 & --- \\
\hline 11 & --- & --- & --- & 101 & 99 & 99 & --- \\
\hline 12 & --- & --- & --. & 97 & 93 & 101 & --- \\
\hline 13 & $\ldots$ & --- & $\cdots$ & 100 & 96 & 109 & --. \\
\hline 14 & --- & -.- & --- & 100 & 96 & 104 & --- \\
\hline 15 & $\cdots$ & --- & --- & 99 & 92 & 99 & -.. \\
\hline 16 & 91 & --- & --- & 106 & 92 & 103 & --- \\
\hline 17 & 89 & --- & --- & 115 & 95 & 103 & --- \\
\hline 18 & 92 & --- & 101 & 110 & 95 & 105 & --- \\
\hline 19 & 90 & --- & 101 & 106 & 96 & 110 & --- \\
\hline 20 & 92 & --- & 107 & 109 & 87 & 110 & --. \\
\hline 21 & 89 & --- & 107 & 111 & 86 & 105 & --- \\
\hline 22 & 94 & --- & 97 & 111 & 87 & 106 & --- \\
\hline 23 & 97 & --. & 98 & 105 & 94 & 106 & --- \\
\hline 24 & 96 & --- & 104 & I18 & 99 & 107 & --. \\
\hline 25 & 95 & -- & 105 & 141 & 98 & 106 & --- \\
\hline 26 & 93 & --- & 104 & 122 & 100 & 105 & -.. \\
\hline 27 & 89 & --- & 106 & 111 & 100 & 106 & -- \\
\hline 28 & --- & --- & 106 & 119 & 106 & 108 & --- \\
\hline 29 & --- & --- & 106 & --- & 119 & 107 & --. \\
\hline 30 & --- & -- & 106 & -.- & 116 & 103 & --- \\
\hline 31 & --- & --- & 103 & --- & 106 & --- & --- \\
\hline
\end{tabular}

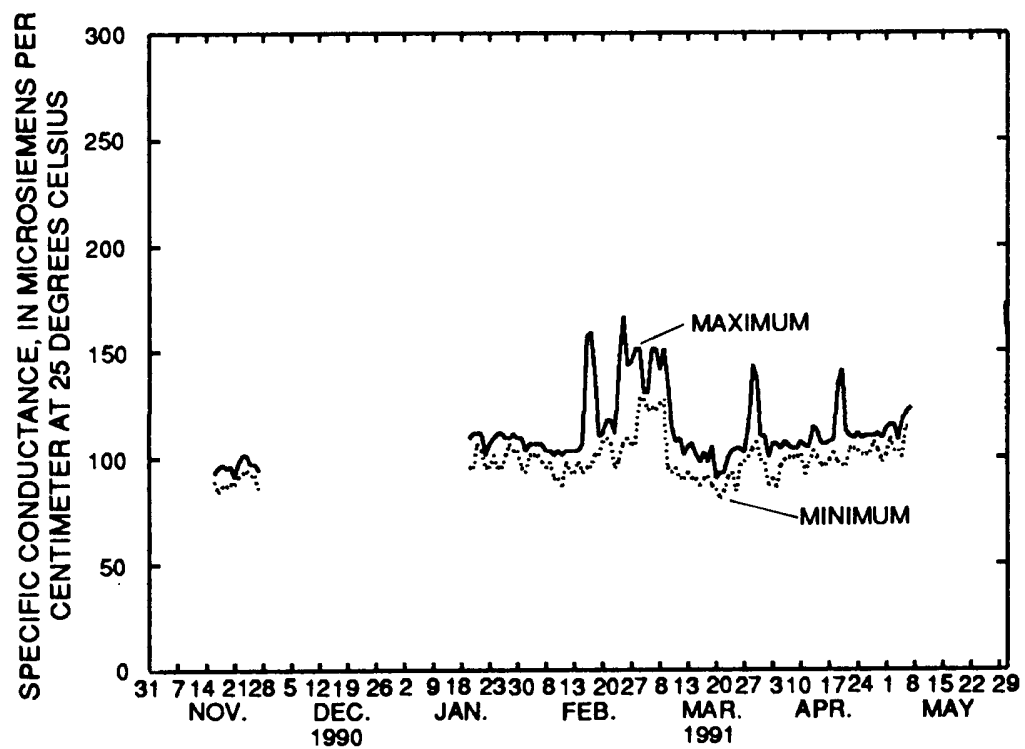


Table 20.--Daily mean values of salinity concentration, near bottom, in water at site 2, Roanoke River at light 1 , November 1990 through May 1991

STATION NUMBER AND NAME: 0208411443, Roanoke River at light 1

LATITUDE: $35^{\circ} 57^{\prime} 17^{\prime \prime}$ LONGITUDE: 76³9'52" COUNTY: Washington

PROBE LOCATION: 2 feet above bottom

[Salinity concentration, parts per thousand; ---, no data]

\begin{tabular}{|c|c|c|c|c|c|c|c|}
\hline Day & Nov. & Dec. & Jan. & Feb. & Mar. & Apr. & May \\
\hline 1 & $\ldots$ & -.. & --- & 0.04 & 0.05 & 0.04 & 0.04 \\
\hline 2 & --- & --. & --- & .04 & .05 & .04 & .04 \\
\hline 3 & --- & --. & --- & .04 & .05 & .04 & .04 \\
\hline 4 & --- & $\cdots$ & --- & .04 & .06 & .04 & .04 \\
\hline 5 & --- & --. & $\cdots$ & .04 & .05 & .04 & .04 \\
\hline 6 & -- & $\cdots$ & --. & .04 & .05 & .04 & .05 \\
\hline 7 & $\cdots$ & -- & --- & .04 & .06 & .04 & .05 \\
\hline 8 & --- & --- & --- & .04 & .05 & .04 & --- \\
\hline 9 & -- & --. & --- & .04 & .04 & .04 & -- \\
\hline 10 & --- & $\cdots$ & $\cdots$ & .04 & .04 & .04 & $\cdots$ \\
\hline 11 & $\cdots$ & -- & $\cdots$ & .04 & .04 & .04 & -.. \\
\hline 12 & --- & -- & $\cdots$ & .04 & .04 & .04 & $\cdots$ \\
\hline 13 & $\cdots$ & -- & $\cdots$ & .04 & .04 & .04 & $\cdots$ \\
\hline 14 & $\cdots$ & -- & --- & .04 & .04 & .04 & --- \\
\hline 15 & $\cdots$ & -- & --- & .04 & .04 & .04 & --- \\
\hline 16 & 0.04 & -- & $--\cdot$ & .04 & .04 & .04 & $\cdots$ \\
\hline 17 & .04 & --. & --- & .05 & .04 & .04 & -.. \\
\hline 18 & .04 & --- & 0.04 & .04 & .04 & .04 & $\cdots$ \\
\hline 19 & .04 & -- & .04 & .04 & .04 & .04 & -- \\
\hline 20 & .04 & $\cdots$ & .04 & .04 & .03 & .04 & -- \\
\hline 21 & .04 & -.. & .04 & .04 & .03 & .04 & --- \\
\hline 22 & .04 & $\cdots$ & .04 & .04 & .03 & .04 & --. \\
\hline 23 & .04 & • --- & .04 & .04 & .04 & .04 & $\cdots$ \\
\hline 24 & .04 & -.. & .04 & .05 & .04 & .04 & --- \\
\hline 25 & .04 & $\cdots$ & .04 & .06 & .04 & .04 & -- \\
\hline 26 & .04 & -- & .04 & .05 & .04 & .04 & -- \\
\hline 27 & .04 & -- & .04 & .04 & .04 & .04 & -- \\
\hline 28 & $\cdots$ & $\cdots$ & .04 & .05 & .04 & .04 & -- \\
\hline 29 & $\cdots$ & --. & .04 & -- & .05 & .04 & -- \\
\hline 30 & $\cdots$ & $\cdots$ & .04 & $\cdots$ & .05 & .04 & --- \\
\hline 31 & --- & $\cdots$ & .04 & $\cdots$ & .04 & -- & -- \\
\hline
\end{tabular}

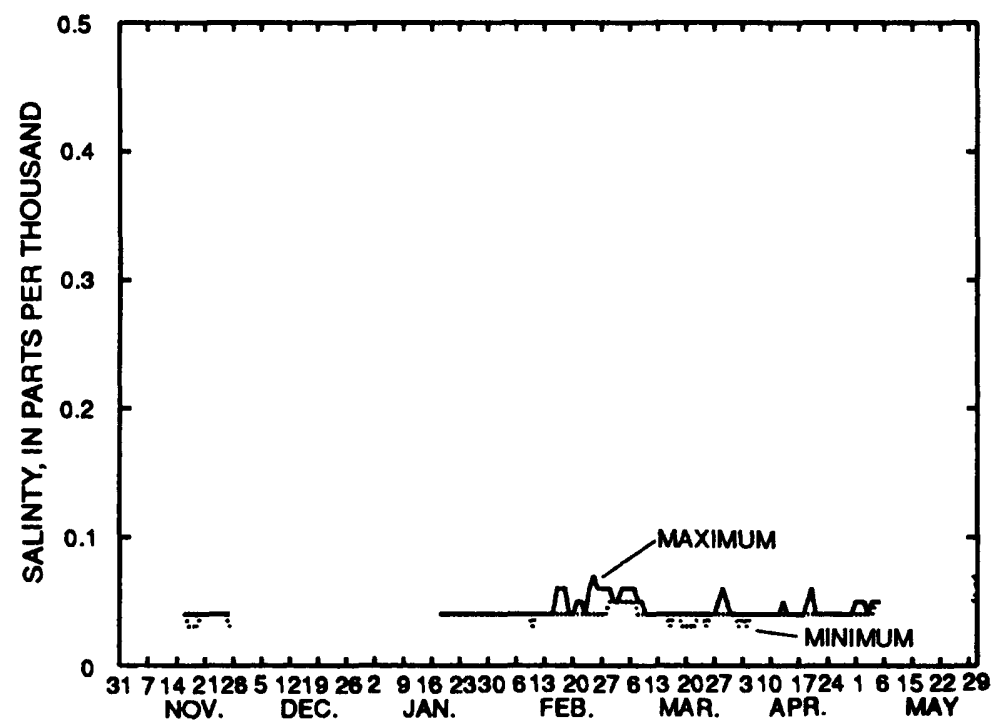


Table 21.--Daily mean values of water temperature, near surface, in water at site 2, Roanoke River at light 1 , November 1990 through May 1991

STATION NUMBER AND NAME: 0208411443, Roanoke River at light 1 LATITUDE: 35'57'17" LONGITUDE: 76³9'52" COUNTY: Washington PROBE LOCATION: 10 feet above bottom

[Water temperature, degrees Celsius; ---, no data]

\begin{tabular}{|c|c|c|c|c|c|c|c|}
\hline Day & Nov. & Dec. & Jan. & Feb. & Mar. & Apr. & May \\
\hline 1 & $\ldots$ & --- & --. & --. & $\ldots$ & --. & --. \\
\hline 2 & --. & --- & -.. & --. & $\ldots$ & ... & $\ldots$ \\
\hline 3 & --- & $\ldots$ & ... & $\ldots$ & -.. & .-. & ... \\
\hline 4 & ... & -.. & ... & --. & --- & --.- & $\ldots$ \\
\hline 5 & --- & --- & --- & --- & $\ldots$ & ... & -.- \\
\hline 6 & -.. & --. & $\cdots$ & $\cdots$ & --. & --- & -.. \\
\hline 7 & $\ldots$ & -.- & -.. & --- & -.- & -.. & -.- \\
\hline 8 & --- & --- & --- & --- & $\cdots$ & $\ldots$ & -.. \\
\hline 9 & --. & --- & -- & --- & $\cdots$ & -.- & --- \\
\hline 10 & --- & -.- & -.. & $\ldots$ & -.. & -.. & ... \\
\hline 11 & --- & --- & $\cdots$ & --- & --- & --- & -.- \\
\hline 12 & $\ldots$ & -.. & .-. & --- & --.- & -.. & $\ldots$ \\
\hline 13 & --- & --- & -.- & ..- & --- & .-. & ... \\
\hline 14 & --. & --. & --. & $\ldots$ & $\ldots$ & --- & --- \\
\hline 15 & --- & --- & --- & --- & --- & -.. & $\ldots$ \\
\hline 16 & 12.6 & --- & --- & $\cdots$ & --- & --- & $\ldots$ \\
\hline 17 & 12.6 & --- & --- & $\cdots$ & $\cdots$ & --- & -.- \\
\hline 18 & 11.7 & -.. & -.. & $\ldots$ & ... & ... & ..- \\
\hline 19 & 11.3 & --. & --. & $-\cdots$ & -.- & -.. & -.. \\
\hline 20 & 11.6 & --. & --- & --- & --. & -.. & -.. \\
\hline 21 & 11.7 & --- & --- & --- & -.. & --. & $\ldots$ \\
\hline 22 & 12.0 & -.. & --- & --- & --. & ... & ...- \\
\hline 23 & 12.1 & --- & -- & --- & $\ldots$ & --. & -.. \\
\hline 24 & 12.3 & --- & -.. & ... & $\ldots$ & .-. & ..- \\
\hline 25 & 12.2 & --- & --. & --- & -- & --- & --- \\
\hline 26 & 12.5 & -.. & --- & --- & --- & --. & ... \\
\hline 27 & 12.8 & --- & --. & -- & $\ldots$ & $\cdots$ & -..- \\
\hline 28 & --- & ... & -.. & $\ldots$ & --- & --- & ...- \\
\hline 29 & --- & --- & -- & --. & -- & --. & --- \\
\hline 30 & ..- & --. & --. & --- & --- & ... & -..- \\
\hline 31 & --- & -.- & -.. & ... & $\ldots$ & --- & -.- \\
\hline
\end{tabular}

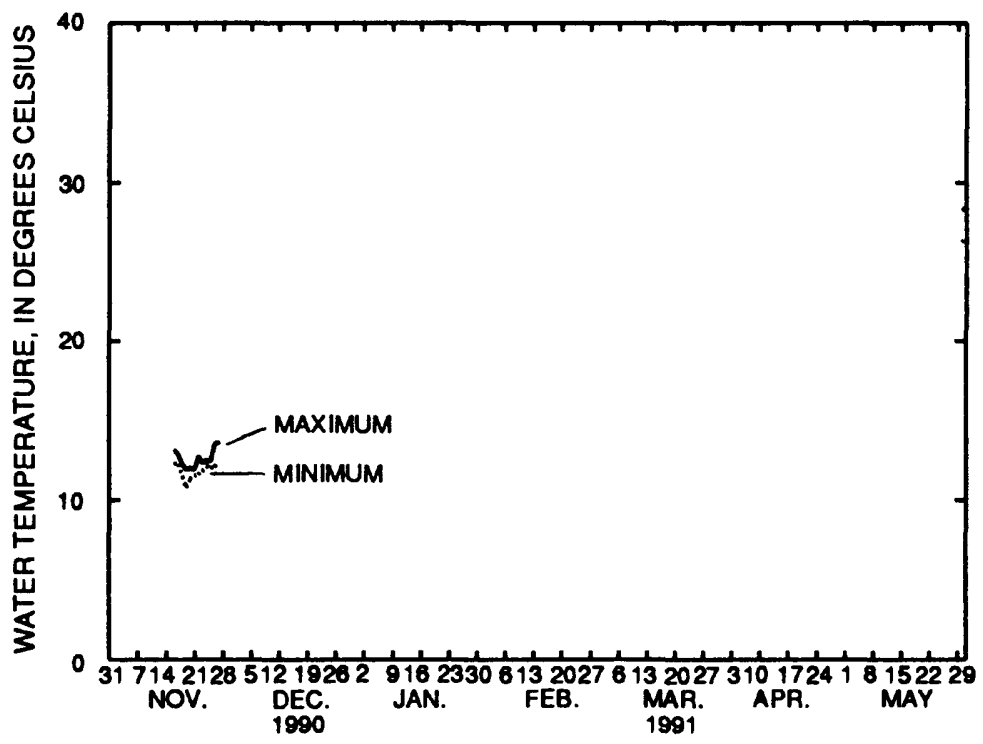


Table 22.--Daily mean values of dissolved-oxygen concentration, near surface, in water at site 2, Roanoke River at light 1 , November 1990 through May 1991

STATION NUMBER AND NAME: 0208411443, Roanoke River at light 1 LATITUDE: $35^{\circ} 5^{\prime} 17^{\prime \prime}$ LONGITUDE: 76³9'52" COUNTY: Washington

PROBE LOCATION: 10 feet above bottom

[Dissolved-oxygen concentration, milligrams per liter; ---, no data]

\begin{tabular}{|c|c|c|c|c|c|c|c|}
\hline Day & Nov. & Dec. & Jan. & Feb. & Mar. & Apr. & May \\
\hline 1 & $\ldots$ & -.- & --- & $\ldots$ & -- & $\cdots$ & 6.1 \\
\hline 2 & --- & --- & --- & --- & -- & -- & 6.0 \\
\hline 3 & --- & --- & --. & --- & --. & -.. & 6.0 \\
\hline 4 & --- & -- & -- & -- & $\cdots$ & $\cdots$ & 6.9 \\
\hline 5 & --- & --- & -- & $\cdots$ & $\cdots$ & $\cdots$ & 6.7 \\
\hline 6 & -... & -.- & -.. & -.. & --- & --. & 6.9 \\
\hline 7 & --- & --- & --- & --- & $\cdots$ & -- & 7.3 \\
\hline 8 & --- & --- & --- & --- & $\ldots$ & -- & --- \\
\hline 9 & --- & --- & --- & --. & -.. & -.- & -.. \\
\hline 10 & $\cdots$ & -- & -- & -- & -- & --- & --- \\
\hline 11 & --- & -.. & --- & $\ldots$ & ... & --. & -.- \\
\hline 12 & --. & --- & --. & -.- & --- & $\ldots$ & -.- \\
\hline 13 & $\cdots$ & --. & $\cdots$ & -- & --- & $\cdots$ & --- \\
\hline 14 & $\ldots$ & --. & -.- & $\ldots$ & --- & -.- & --.- \\
\hline 15 & --- & -- & --- & -- & $\ldots$ & --- & --- \\
\hline 16 & 6.0 & --. & --. & -.. & .-. & --- & --. \\
\hline 17 & 6.9 & --. & --- & $\cdots$ & --- & --- & --. \\
\hline 18 & 8.1 & $\ldots$ & $\ldots$ & --- & --- & -- & --. \\
\hline 19 & 7.8 & --. & --. & --- & -- & 7.6 & --. \\
\hline 20 & 6.4 & --- & $\cdots$ & --- & $\cdots$ & 8.1 & --- \\
\hline 21 & 6.3 & --- & --. & ..- & $\ldots$ & 7.7 & -.- \\
\hline 22 & 6.1 & --. & --- & $\cdots$ & -- & 6.5 & --- \\
\hline 23 & 6.7 & -.. & --- & --- & $\ldots$ & 6.3 & --. \\
\hline 24 & 7.5 & -.- & $\ldots$ & -.- & -.- & 6.4 & --. \\
\hline 25 & 8.2 & $\ldots$ & -. & --- & $\cdots$ & 7.1 & --- \\
\hline 26 & 8.3 & --- & --- & --- & --- & 6.8 & --- \\
\hline 27 & 8.3 & -.. & --- & $\ldots$ & $\ldots$ & 6.6 & --. \\
\hline 28 & --- & $\ldots$ & $\cdots$ & $\cdots$ & --- & 7.0 & --- \\
\hline 29 & $\ldots$ & $\ldots$ & --- & -- & --. & 6.7 & --. \\
\hline 30 & --- & --- & --- & --- & --- & 6.4 & $\cdots$ \\
\hline 31 & --- & --- & --- & --- & --. & -- & --- \\
\hline
\end{tabular}

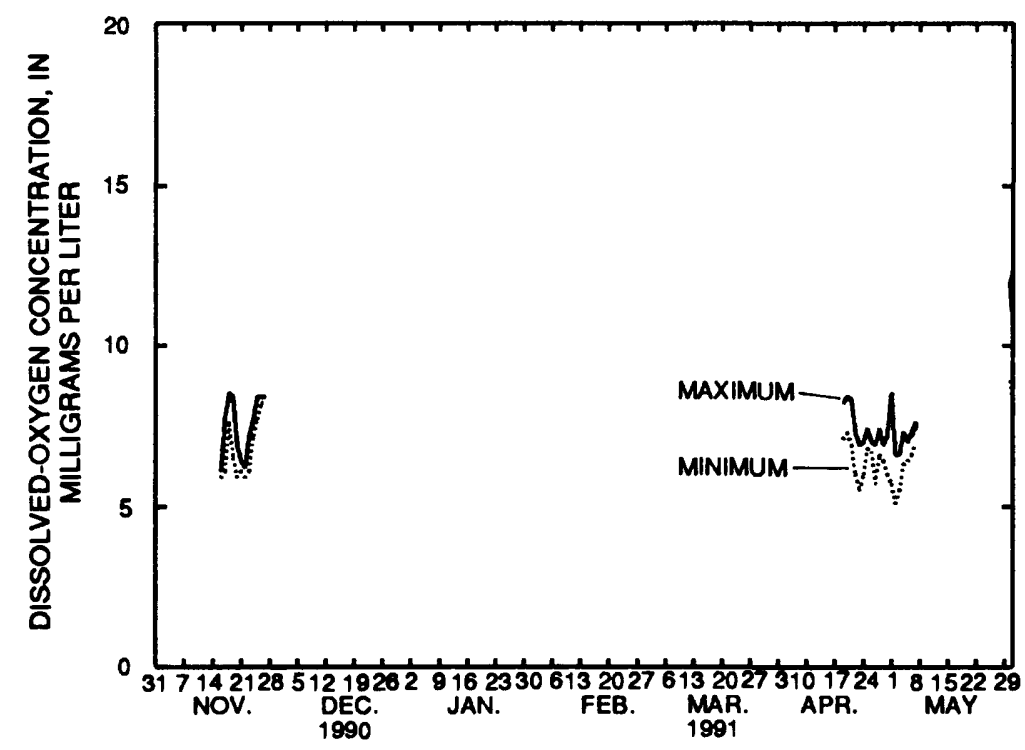


Table 23.--Daily mean values of dissolved-oxygen concentration, mid-depth, in water at site 2, Roanoke River at light 1, November 1990 through May 1991

STATION NUMBER AND NAME: 0208411443, Roanoke River at light 1

LATITUDE: 35'57'17" LONGITUDE: 76³9'52" COUNTY: Washington

PROBE LOCATION: 6 feet above bottom

[Dissolved-oxygen concentration, milligrams per liter; ---, no data]

\begin{tabular}{|c|c|c|c|c|c|c|c|}
\hline Day & Nov. & Dec. & Jan. & Feb. & Mar. & Apr. & May \\
\hline 1 & --- & --- & --- & 11.1 & 11.0 & 7.8 & --- \\
\hline 2 & --- & -.. & --- & 10.3 & 10.9 & 8.2 & --- \\
\hline 3 & --- & --- & --- & 10.4 & 10.7 & 8.9 & $\ldots$ \\
\hline 4 & -.- & --. & --- & 10.4 & 11.0 & 9.1 & -.- \\
\hline 5 & --- & --- & --- & 10.4 & 10.6 & 8.7 & --. \\
\hline 6 & 7.2 & -.- & -.. & 10.3 & 10.5 & 8.5 & -.. \\
\hline 7 & 7.0 & --- & --- & 10.2 & 10.7 & 8.5 & --. \\
\hline 8 & --. & --- & --- & 10.4 & 10.1 & 8.3 & -.. \\
\hline 9 & --- & $\cdots$ & $\cdots$ & 10.3 & 10.2 & 8.4 & $\cdots$ \\
\hline 10 & --- & --. & --- & 9.9 & 10.4 & 8.4 & $\cdots$ \\
\hline 11 & --. & -.- & -.. & 10.0 & 10.8 & 8.1 & --- \\
\hline 12 & --- & --- & --- & 10.6 & 10.9 & 8.2 & --- \\
\hline 13 & --- & --. & -.. & 10.8 & 10.8 & 9.2 & --. \\
\hline 14 & $\cdots$ & --- & --- & 10.8 & 10.7 & 8.4 & --- \\
\hline 15 & --. & --- & --- & 10.8 & 10.9 & 8.2 & --- \\
\hline 16 & 6.3 & --- & --- & 11.7 & 10.9 & 7.8 & --. \\
\hline 17 & 7.3 & --- & --. & 12.0 & 10.6 & 7.2 & --. \\
\hline 18 & 8.7 & $\ldots$ & 10.3 & 12.0 & 10.6 & 7.3 & $\cdots$ \\
\hline 19 & 8.1 & --- & 10.2 & 10.8 & 10.6 & 7.7 & --- \\
\hline 20 & 6.6 & --. & 10.0 & 11.0 & 10.6 & 7.5 & --- \\
\hline 21 & 6.3 & -.. & 10.3 & 10.9 & 10.3 & --- & --. \\
\hline 22 & 6.1 & ..- & 11.0 & 10.8 & 10.0 & --- & --- \\
\hline 23 & 6.7 & --- & 10.9 & 10.9 & 9.7 & -- & $\cdots$ \\
\hline 24 & 7.6 & $\ldots$ & 10.6 & 11.4 & 9.6 & --- & --- \\
\hline 25 & 8.3 & $\cdots$ & 11.0 & 11.5 & 9.4 & -- & $\cdots$ \\
\hline 26 & 8.4 & --- & 11.4 & 11.2 & 9.6 & -- & --- \\
\hline 27 & 8.3 & -.- & 10.9 & 10.9 & 9.5 & --- & $\cdots$ \\
\hline 28 & --- & --- & 11.0 & 11.2 & 9.7 & --- & --- \\
\hline 29 & --. & ... & 10.8 & -- & 9.6 & --- & -- \\
\hline 30 & --- & -- & 10.6 & --- & 9.4 & -- & $\cdots$ \\
\hline 31 & --- & --- & 10.9 & --- & 9.2 & --- & $\cdots$ \\
\hline
\end{tabular}

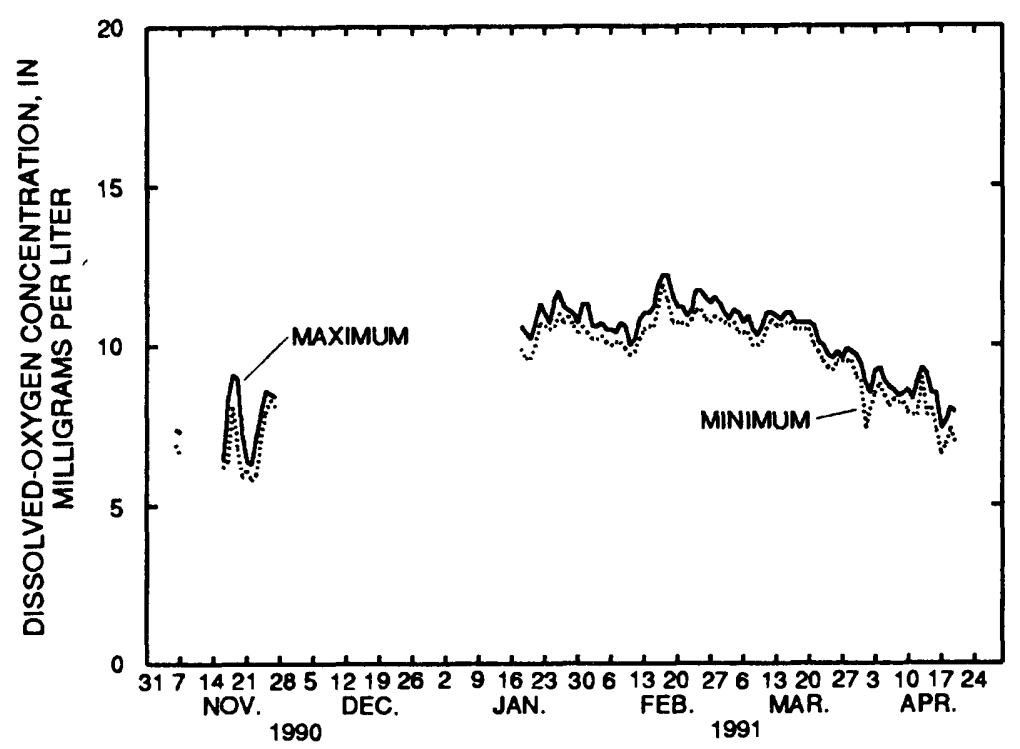


Table 24.--Daily mean values of dissolved-oxygen concentration, near bottom, in water at site 2, Roanoke River at light 1 , November 1990 through May 1991

STATION NUMBER AND NAME: 0208411443, Roanoke River at light 1 LATITUDE: $35^{\circ} 57^{\prime} 17^{\prime \prime}$ LONGITUDE: 76³9'52" COUNTY: Washington PROBE LOCATION: 2 feet above bottom

[Dissolved-oxygen concentration, milligrams per liter; ---, no data]

\begin{tabular}{|c|c|c|c|c|c|c|c|}
\hline Day & Nov. & Dec. & Jan. & Feb. & Mar. & Apr. & May \\
\hline 1 & --- & --. & --. & 11.0 & 11.2 & 7.6 & 5.2 \\
\hline 2 & $\ldots$ & $\ldots$ & --. & 10.2 & 11.0 & 8.0 & 5.8 \\
\hline 3 & $\cdots$ & --- & ..- & 10.3 & 10.9 & 8.7 & 6.3 \\
\hline 4 & $\ldots$ & --. & --- & 10.3 & 11.1 & 8.9 & 7.1 \\
\hline 5 & $\cdots$ & --- & --- & 10.3 & 10.8 & 8.5 & 6.6 \\
\hline 6 & $\ldots$ & --- & --- & 10.2 & 10.7 & 8.2 & 7.0 \\
\hline 7 & $\cdots$ & $\cdots$ & --- & 10.1 & 10.9 & 8.1 & 7.4 \\
\hline 8 & --. & --. & -.- & 10.4 & 10.3 & 8.3 & --. \\
\hline 9 & $\cdots$ & -- & $\ldots$ & 10.3 & 10.3 & 8.4 & --. \\
\hline 10 & $\cdots$ & --. & --- & 9.8 & 10.6 & 8.3 & -.. \\
\hline 11 & --. & --. & ...- & 10.0 & 11.0 & 7.9 & -.- \\
\hline 12 & $\ldots$ & ... & -.. & 10.6 & 11.1 & 8.1 & ... \\
\hline 13 & --. & --. & -.. & 10.8 & 11.1 & 9.0 & --. \\
\hline 14 & -.- & $\ldots$ & $\cdots$ & 10.8 & 10.9 & 8.2 & -.. \\
\hline 15 & $\cdots$ & --. & --- & 10.8 & 11.1 & 8.2 & --- \\
\hline 16 & --- & -.. & --. & 11.7 & 11.2 & 7.8 & --- \\
\hline 17 & $\cdots$ & $\cdots$ & --- & 12.0 & 10.9 & 7.1 & ... \\
\hline 18 & ... & --- & 10.1 & 12.0 & 10.8 & 7.3 & $\ldots$ \\
\hline 19 & -.. & --- & 10.0 & 11.0 & 10.7 & 8.3 & --- \\
\hline 20 & $\cdots$ & -.. & 9.7 & 11.0 & 10.7 & 8.8 & --. \\
\hline 21 & --. & --- & 10.1 & 10.9 & 10.3 & 8.4 & --. \\
\hline 22 & $\cdots$ & --- & 10.8 & 10.7 & 9.9 & 7.0 & --- \\
\hline 23 & -- & --- & 10.6 & 10.9 & 9.4 & 7.0 & -.. \\
\hline 24 & --- & --- & 10.4 & 11.4 & 9.4 & 7.0 & --- \\
\hline 25 & -- & --- & 10.8 & 11.6 & 9.2 & 7.4 & --- \\
\hline 26 & $\cdots$ & ... & 11.1 & 11.3 & 9.4 & 6.9 & -.. \\
\hline 27 & -- & -.- & 10.7 & 11.0 & 9.4 & 6.9 & --- \\
\hline 28 & -- & --- & 10.9 & 11.3 & 9.5 & 6.6 & --- \\
\hline 29 & --- & --- & 10.7 & -.- & 9.4 & 6.1 & --- \\
\hline 30 & -.- & --- & 10.5 & --- & 9.2 & 5.8 & --- \\
\hline 31 & $\cdots$ & --. & 10.8 & --- & 8.9 & --- & --- \\
\hline
\end{tabular}

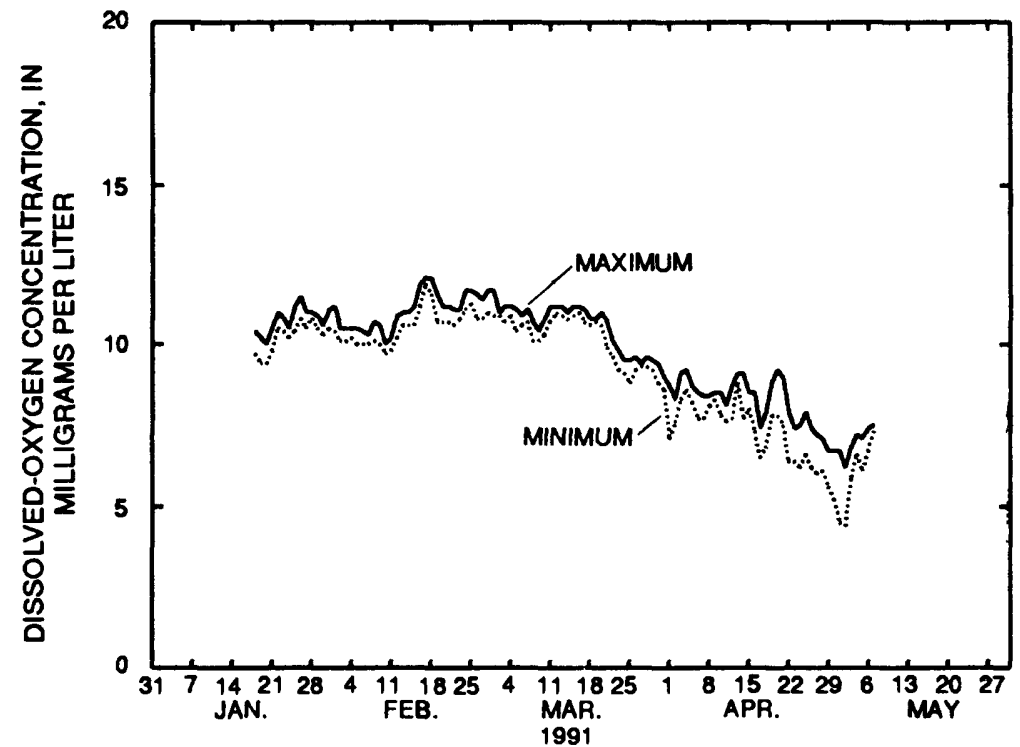


Table 25.--Daily mean values of specific conductance, near surface, in water at site 3, Albemarle Sound at light 3, January through September 1990

STATION NUMBER AND NAME: 0208115600 , Albemarle Sound at light 3

LATITUDE: $36^{\circ} 00^{\prime} 06^{\prime \prime}$ LONGITUDE: $76^{\circ} 23^{\prime} 36^{\prime \prime}$. COUNTY: Washington

PROBE LOCATION: 7 feet above bottom

[Specific conductance, microsiemens per centimeter at 25 degrees Celsius; ---, no data]

\begin{tabular}{|c|c|c|c|c|c|c|c|c|c|}
\hline Day & Jan. & Feb. & Mar. & Apr. & May & June & July & Aug. & Sept. \\
\hline 1 & -..- & $\ldots$ & $\ldots$ & 330 & 117 & 128 & ... & 1,650 & 1,050 \\
\hline 2 & .-. & .-. & -.- & 346 & 118 & 120 & -..- & 1,810 & 926 \\
\hline 3 & $\cdots$ & --- & -- & 332 & 175 & 116 & $\cdots$ & 1,820 & 1,140 \\
\hline 4 & --. & --- & -.. & 226 & 189 & 107 & $\ldots$ & 1,660 & 1,850 \\
\hline 5 & --. & --- & $\cdots$ & 237 & 174 & 116 & -- & 1,520 & 1,950 \\
\hline 6 & --. & -.- & -.. & 250 & 139 & -.. & $\ldots$ & 1,140 & 1,890 \\
\hline 7 & -.. & -.. & -.- & 224 & 135 & --. & 266 & 1,090 & 1,670 \\
\hline 8 & $\ldots$ & -.- & --. & 191 & 121 & $\ldots$ & 260 & 1,280 & 1,910 \\
\hline 9 & $\ldots$ & -.. & --. & 189 & 115 & $\ldots$ & $\cdots$ & 1,260 & 2,720 \\
\hline 10 & $\cdots$ & $\cdots$ & $\cdots$ & 206 & 122 & $\cdots$ & 273 & 1,080 & 1,900 \\
\hline 11 & -.- & -.- & -.- & 170 & 116 & -.. & 266 & 948 & 1,970 \\
\hline 12 & -.- & --- & -.. & 133 & 120 & -.- & 240 & 863 & 2,330 \\
\hline 13 & ... & --- & -.- & 200 & 122 & -.. & 318 & 743 & 2,500 \\
\hline 14 & --- & --. & -.. & 210 & 118 & --. & 334 & 683 & 1.950 \\
\hline 15 & -.. & -.. & $\ldots$ & 164 & $\cdots$ & ... & 412 & 732 & 1,840 \\
\hline 16 & --. & --- & -. & 139 & --. & -.. & 398 & 669 & 2,040 \\
\hline 17 & --- & --- & $\ldots$ & 150 & $\ldots$ & --. & 377 & 784 & 2,350 \\
\hline 18 & --. & -.. & -.. & 143 & -.- & --- & 542 & 1,110 & 2,380 \\
\hline 19 & 554 & $\ldots$ & $\ldots$ & 198 & $\cdots$ & --. & 549 & 959 & 2,160 \\
\hline 20 & 531 & --- & -.- & 278 & -- & --. & 525 & 737 & 2,050 \\
\hline 21 & 483 & -.- & -.- & 202 & -.- & --- & 630 & 1,290 & 2,340 \\
\hline 22 & 475 & ... & 320 & 231 & ... & --- & 796 & 1,510 & 2,620 \\
\hline 23 & 448 & $\ldots$ & 206 & 196 & --. & --. & 604 & 1,310 & 2,040 \\
\hline 24 & 368 & --. & 561 & 130 & --. & -.- & 842 & 1,130 & 2,330 \\
\hline 25 & 464 & --. & 769 & 115 & 135 & -.. & 1,150 & 817 & 2,150 \\
\hline 26 & 876 & ... & 691 & 106 & 136 & $\ldots$ & 1,150 & 750 & 1,820 \\
\hline 27 & 1,080 & --. & 669 & 101 & 132 & $\ldots$ & 1,200 & 762 & 2,110 \\
\hline 28 & 1,150 & --. & 997 & 106 & 175 & -.. & 1,410 & 649 & 2,200 \\
\hline 29 & 977 & -.- & 988 & 106 & 181 & ... & 1,430 & 446 & 2,590 \\
\hline 30 & 1,590 & --- & 751 & 112 & 127 & -.. & 1,560 & 508 & 2,360 \\
\hline 31 & --. & -.. & 398 & -.- & 146 & $\ldots$ & 1,620 & 880 & --. \\
\hline
\end{tabular}

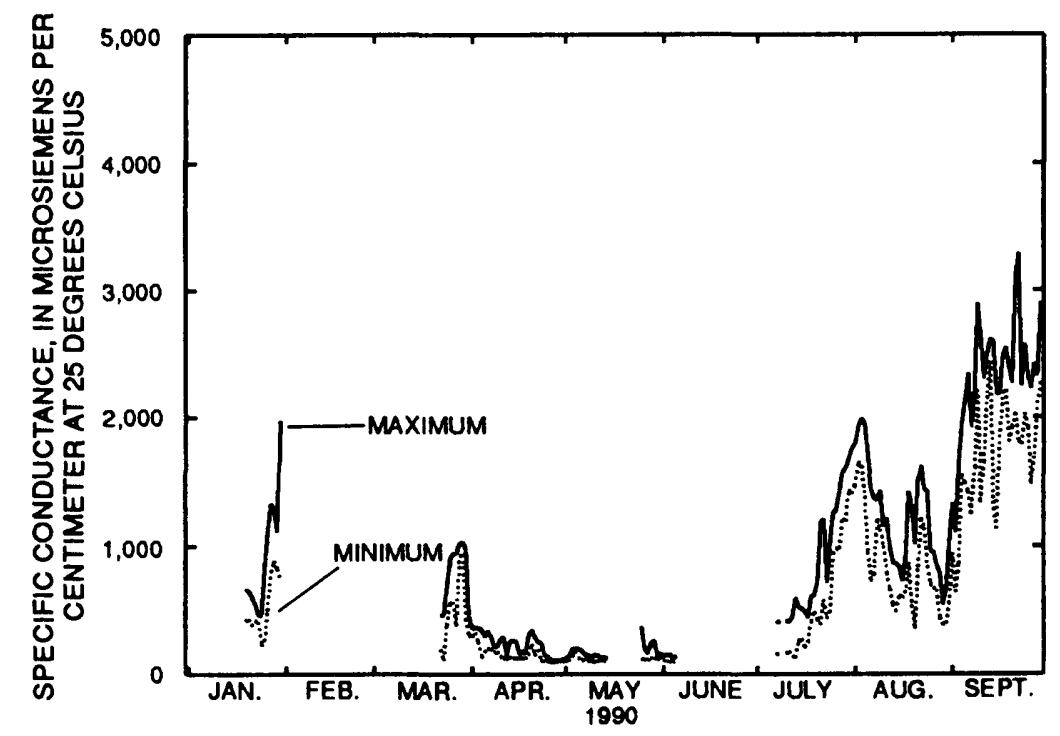


Table 26.--Daily mean values of specific conductance, near surface, in water at site 3, Albemarle Sound at light 3 , October 1990 through May 1991

STATION NUMBER AND NAME: 0208115600, Albemarle Sound at light 3 LATITUDE: $36^{\circ} 00^{\prime} 06^{\prime \prime}$ LONGITUDE: $76^{\circ} 23^{\prime} 36^{\prime \prime}$ COUNTY: Washington PROBE LOCATION: 7 feet above bottom

[Specific conductance, microsiemens per centimeter at 25 degrees Celsius; ---, no data]

\begin{tabular}{|c|c|c|c|c|c|c|c|c|}
\hline Day & Oct. & Nov. & Dec. & Jan. & Feb. & Mar. & Apr. & May \\
\hline I & 2,240 & $\mathrm{I}, 260$ & 1,420 & $\mathrm{I}, 800$ & --- & 409 & $7 \mathrm{II}$ & 171 \\
\hline 2 & 2,060 & 867 & I, 640 & I,920 & --- & 444 & 460 & I62 \\
\hline 3 & 2,430 & 598 & $\mathrm{I}, 870$ & $I, 860$ & --- & 380 & 739 & 122 \\
\hline 4 & 2,290 & 425 & 1,680 & 2,200 & --- & 314 & 884 & I3I \\
\hline 5 & 2,100 & 360 & 987 & 1,920 & --- & 310 & 497 & 162 \\
\hline 6 & 2,030 & 449 & 542 & 1,440 & --- & 275 & 226 & 183 \\
\hline 7 & 2,110 & $\mathrm{I}, 020$ & 1,170 & 1,690 & --- & 399 & I89 & --- \\
\hline 8 & $\mathrm{I}, 970$ & 1,620 & 1,820 & I,7I0 & --- & 411 & 170 & $\ldots$ \\
\hline 9 & 2,000 & 2,040 & 1,550 & 687 & --- & 638 & I93 & -.. \\
\hline 10 & 2,160 & $\mathrm{I}, 420$ & 1,460 & $\ldots$ & I8I & $70 \mathrm{I}$ & 262 & --- \\
\hline 11 & $3,2 \mathrm{IO}$ & 636 & $\mathrm{I}, 480$ & --- & 178 & 423 & 511 & --- \\
\hline 12 & 2,610 & 333 & 1,450 & -.. & 153 & 449 & 513 & --- \\
\hline 13 & 2,270 & --- & 1,450 & --- & 162 & 396 & 535 & -- \\
\hline 14 & 2,300 & --- & 2,000 & --- & 148 & --- & 448 & --- \\
\hline 15 & 1,930 & --- & 2,040 & --- & 146 & 367 & 569 & --- \\
\hline I6 & 2,170 & $--\cdot$ & 1,560 & --- & I94 & 536 & $38 \mathrm{I}$ & $\ldots$ \\
\hline 17 & $I, 890$ & 804 & I, 880 & --- & I52 & 421 & 428 & -- \\
\hline I8 & 1,990 & $\mathrm{I}, 600$ & 1,430 & --- & 198 & 400 & -- & --- \\
\hline 19 & 1,930 & I,520 & $\mathrm{I}, 050$ & --- & 174 & I75 & 556 & --- \\
\hline 20 & 2,210 & 1,420 & $\mathrm{I}, 460$ & --- & I94 & 133 & 698 & -- \\
\hline 21 & 2,000 & 1,320 & 1,610 & --- & 289 & 261 & 288 & -- \\
\hline 22 & 1,560 & $\mathrm{I}, 180$ & $\mathrm{I}, 3 \mathrm{IO}$ & --- & 210 & I64 & 448 & -- \\
\hline 23 & $I, 400$ & 886 & I,I 80 & --- & 584 & I6I & $43 I$ & --- \\
\hline 24 & 1,210 & 845 & 964 & --- & 664 & I79 & 383 & $\cdots$ \\
\hline 25 & 1,530 & 655 & 1,630 & $\cdots$ & 667 & 305 & 282 & -- \\
\hline 26 & 1,370 & 970 & 2,320 & --- & 556 & 838 & 311 & --- \\
\hline 27 & 922 & 563 & 2,250 & --- & 474 & 687 & 330 & --- \\
\hline 28 & $\mathrm{I}, 320$ & 703 & 1,900 & $\cdots$ & 404 & 245 & 195 & --- \\
\hline 29 & 1,430 & $\mathrm{I}, \mathrm{I} 40$ & 1,780 & --- & --- & 249 & I60 & --- \\
\hline 30 & 1,840 & $\mathrm{I}, 790$ & 1,340 & --- & --- & 698 & 215 & --- \\
\hline 31 & 1,270 & --- & 932 & --- & --- & $I, 050$ & --- & $\cdots$ \\
\hline
\end{tabular}

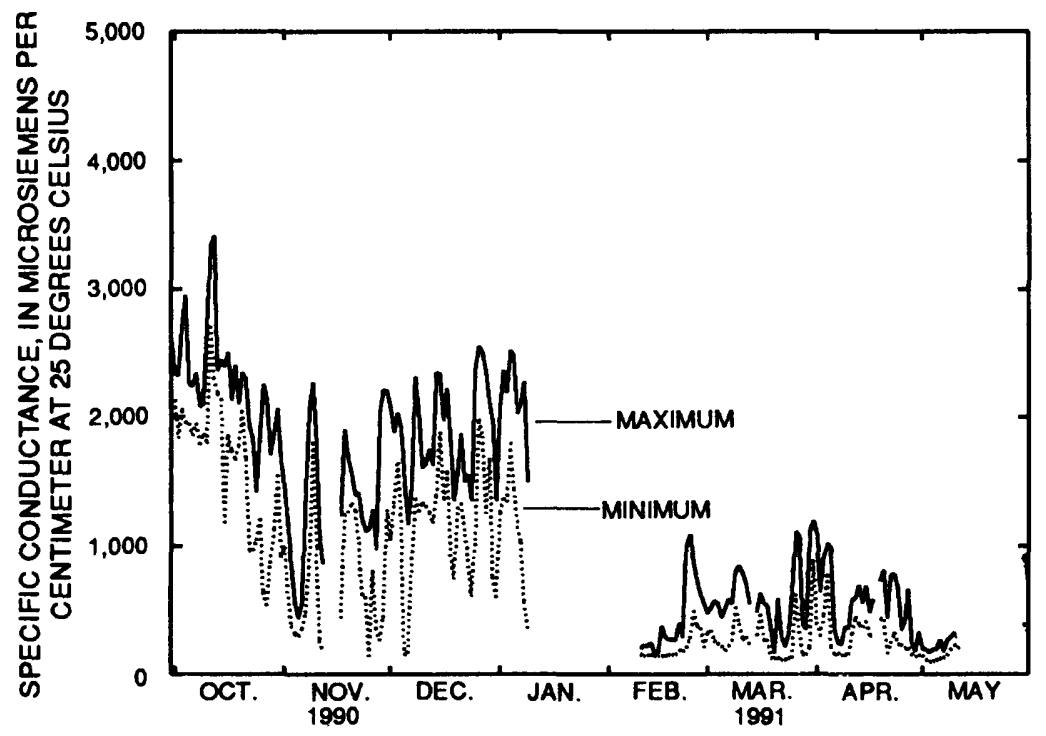


Table 27.--Daily mean values of salinity concentration, near surface, in water at site 3, Albemarle Sound at light 3 , January through September 1990

STATION NUMBER AND NAME: 0208115600, Albemarle Sound at light 3 LATITUDE: $36^{\circ} 00^{\prime} 06^{\prime \prime}$ LONGITUDE: $76^{\circ} 23^{\prime} 36^{\prime \prime}$ COUNTY: Washington PROBE LOCATION: 7 feet above bottom

[Salinity concentration, parts per thousand; -..-, no data]

\begin{tabular}{|c|c|c|c|c|c|c|c|c|c|}
\hline Day & Jan. & Feb. & Mar. & Apr. & May & June & July & Aug. & Sept. \\
\hline 1 & --- & --. & -.. & 0.14 & 0.05 & 0.05 & -.. & 0.81 & 0.50 \\
\hline 2 & $-\ldots$ & --- & -.. & .15 & .05 & .05 & -.. & .90 & .43 \\
\hline 3 & --- & -..- & $\ldots$ & .15 & .07 & .05 & --. & .91 & .55 \\
\hline 4 & --- & -.- & $\ldots$ & .09 & .08 & .04 & -.. & .82 & .92 \\
\hline 5 & --- & --. & $\ldots$ & .10 & .07 & .05 & $\ldots$ & .75 & .97 \\
\hline 6 & --- & ... & $-\cdots$ & .10 & .06 & -.. & ... & .55 & .94 \\
\hline 7 & -- & --- & --- & .09 & .05 & --- & 0.11 & .52 & .82 \\
\hline 8 & --- & --. & -.. & .08 & .05 & --- & .11 & .62 & .95 \\
\hline 9 & --- & --- & --- & .08 & .05 & --- & -.. & .61 & 1.4 \\
\hline 10 & -.. & --. & --- & .08 & .05 & --- & .12 & .51 & .95 \\
\hline 11 & --- & --- & --. & .07 & .05 & --- & .11 & .45 & .99 \\
\hline 12 & --- & -.- & --- & .05 & .05 & ... & .10 & .40 & 1.2 \\
\hline 13 & --- & -.- & --- & .08 & .05 & -.. & .14 & .34 & 1.3 \\
\hline 14 & $\cdots$ & -.- & -.. & .09 & .05 & --- & .15 & .32 & .98 \\
\hline 15 & --- & --- & --- & .07 & --- & --- & .18 & .34 & .91 \\
\hline 16 & --. & --. & -.. & .06 & --. & --- & .18 & .31 & 1.0 \\
\hline 17 & --- & --. & --. & .06 & --. & --_- & .17 & .36 & 1.2 \\
\hline 18 & -.. & --- & --- & .06 & --- & --- & .25 & .53 & 1.2 \\
\hline 19 & 0.25 & --. & --. & .08 & $\ldots$ & --- & .25 & .46 & 1.1 \\
\hline 20 & .24 & $\cdots$ & --- & .12 & --- & --- & .24 & .34 & 1.0 \\
\hline 21 & .22 & $\ldots$ & --. & .08 & -.- & ... & .29 & .63 & 1.2 \\
\hline 22 & .22 & --- & 0.14 & .10 & --- & --- & .37 & .74 & 1.3 \\
\hline 23 & .20 & --- & .09 & .08 & --- & --- & .28 & .64 & 1.0 \\
\hline 24 & .16 & --- & .26 & .05 & --. & --- & .39 & .54 & 1.2 \\
\hline 25 & .21 & --- & .36 & .05 & .05 & --. & .55 & .38 & 1.1 \\
\hline 26 & .41 & --- & .32 & .04 & .05 & --- & .55 & .35 & .91 \\
\hline 27 & .52 & -.- & .31 & .04 & .05 & --- & .58 & .35 & 1.1 \\
\hline 28 & .55 & --- & .47 & .04 & .07 & ... & .69 & .30 & 1.1 \\
\hline 29 & .46 & --- & .46 & .04 & .07 & --- & .70 & .20 & 1.3 \\
\hline 30 & .78 & --- & .35 & .04 & .05 & --- & .77 & .23 & 1.2 \\
\hline 31 & -.. & --- & .18 & --- & .06 & --- & .80 & .41 & --. \\
\hline
\end{tabular}

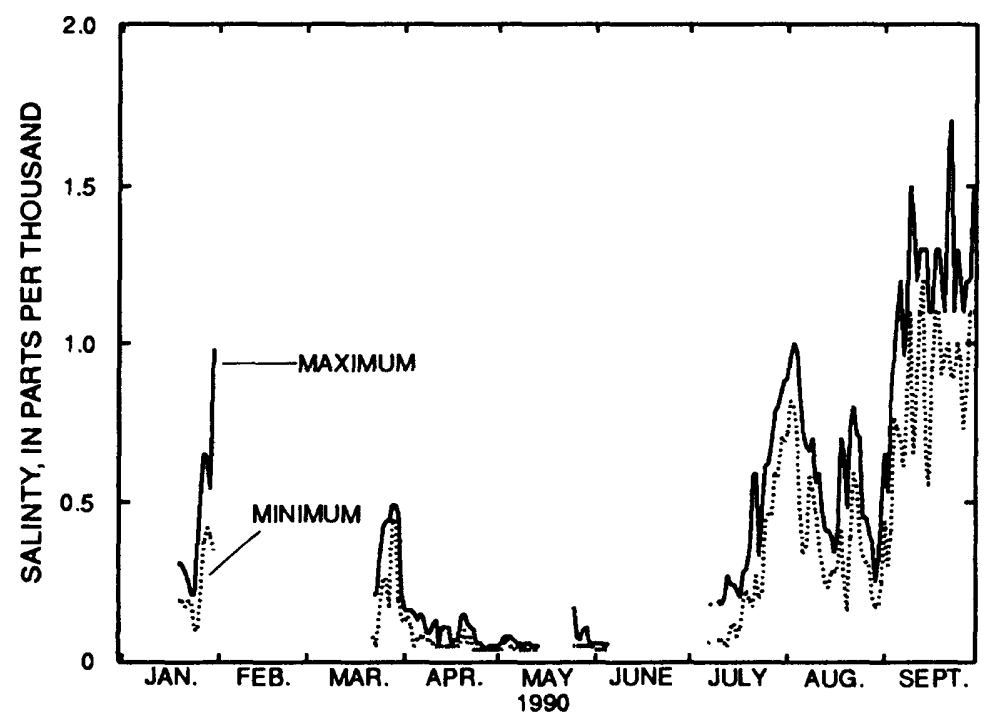


Table 28.--Daily mean values of salinity concentration, near surface, in water at site 3, Albemarle Sound at light 3 ,

October 1990 through May 1991

STATION NUMBER AND NAME: 0208115600, Albermarle Sound at light 3

LATITUDE: $36^{\circ} 00^{\prime} 06^{\prime \prime}$ LONGITUDE: 76 $23^{\prime} 36^{\prime \prime}$ COUNTY: Washington

PROBE LOCATION: 7 feet above bottom

[Salinity concentration, parts per thousand; ---, no data]

\begin{tabular}{|c|c|c|c|c|c|c|c|c|}
\hline Day & Oct. & Nov. & Dec. & Jan. & Feb. & Mar. & Apr. & May \\
\hline 1 & 1.1 & 0.61 & 0.70 & 0.89 & --. & 0.18 & 0.33 & 0.07 \\
\hline 2 & 1.0 & .41 & .81 & .96 & --- & .20 & .21 & .06 \\
\hline 3 & 1.2 & .27 & .93 & .93 & --- & .17 & .34 & .05 \\
\hline 4 & 1.2 & .19 & .83 & 1.1 & --- & .14 & .41 & .05 \\
\hline 5 & 1.1 & .16 & .47 & .96 & --- & .14 & .23 & .06 \\
\hline 6 & 1.0 & .20 & .25 & .70 & -- & .12 & .09 & .07 \\
\hline 7 & 1.1 & .49 & .56 & .84 & $\cdots$ & .18 & .08 & --- \\
\hline 8 & .98 & .80 & .90 & .85 & --. & .18 & .07 & -.. \\
\hline 9 & 1.0 & 1.0 & .76 & .32 & --- & .29 & .08 & --- \\
\hline 10 & 1.1 & .70 & .72 & $\cdots$ & 0.07 & .32 & .11 & $\cdots$ \\
\hline 11 & 1.7 & .29 & .73 & -.- & .07 & .19 & .23 & --. \\
\hline 12 & 1.3 & .15 & .71 & --- & .06 & .20 & .23 & --- \\
\hline 13 & 1.1 & -- & .71 & --. & .06 & .18 & .24 & --- \\
\hline 14 & 1.2 & --- & 1.0 & --- & .06 & --- & .20 & $\cdots$ \\
\hline 15 & .97 & -- & 1.0 & --- & .06 & .16 & .26 & --- \\
\hline 16 & 1.1 & --- & .77 & --. & .08 & .24 & .17 & --- \\
\hline 17 & .94 & .38 & .94 & ..- & .06 & .19 & .19 & - \\
\hline 18 & .99 & .79 & .70 & --- & .08 & .18 & $\ldots$ & -.- \\
\hline 19 & .96 & .75 & .50 & --. & .07 & .07 & .25 & -- \\
\hline 20 & 1.1 & .69 & .72 & $\cdots$ & .08 & .05 & .32 & --- \\
\hline 21 & 1.0 & .64 & .79 & --- & .12 & .11 & .12 & --. \\
\hline 22 & .77 & .57 & .64 & --- & .09 & .07 & .20 & ... \\
\hline 23 & .69 & .42 & .57 & $\ldots$ & .27 & .06 & .19 & $\cdots$ \\
\hline 24 & .58 & .40 & .46 & --- & .31 & .07 & .17 & -- \\
\hline 25 & .75 & .30 & .81 & -.- & .31 & .13 & .12 & -- \\
\hline 26 & .67 & .46 & 1.2 & --- & .25 & .39 & .14 & $\cdots$ \\
\hline 27 & .44 & .26 & 1.1 & --- & .21 & .32 & .14 & -- \\
\hline 28 & .65 & .33 & .95 & -..- & .18 & .10 & .08 & --- \\
\hline 29 & .70 & .55 & .89 & --. & $\cdots$ & .10 & .06 & --- \\
\hline 30 & .92 & .89 & .65 & --- & --- & .32 & .09 & -. \\
\hline 31 & .62 & - & .44 & - & - & .50 & --- & \\
\hline
\end{tabular}

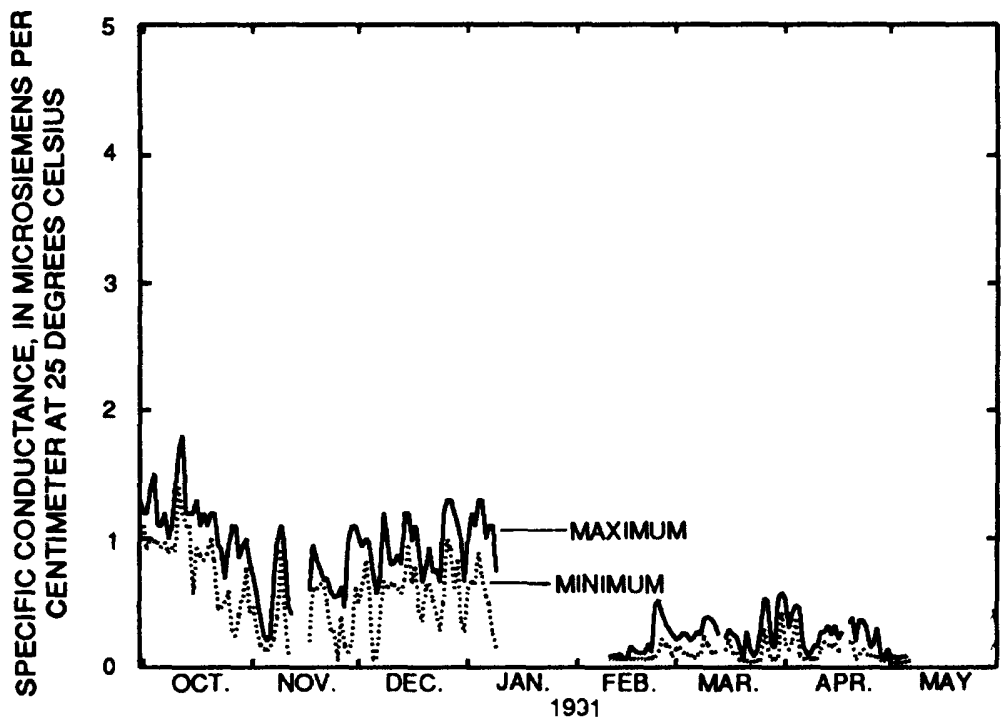


Table 29.--Daily mean values of specific conductance, near bottom, in water at site 3, Albemarle Sound at light 3 , January through September 1990

STATION NUMBER AND NAME: 0208115600, Albemarle Sound at light 3 LATITUDE: $36^{\circ} 00^{\prime} 06^{\prime \prime}$ LONGITUDE: 76'23'36" COUNTY: Washington PROBE LOCATION: 2 feet above bottom

[Specific conductance, microsiemens per centimeter at 25 degrees Celsius; ---, no data]

\begin{tabular}{|c|c|c|c|c|c|c|c|c|c|}
\hline Day & Jan. & Feb. & Mar. & Apr. & May & June & July & Aug. & Sept. \\
\hline 1 & -- & -- & --- & 326 & 117 & 142 & $\ldots$ & 1,810 & 1,110 \\
\hline 2 & --- & $\ldots$ & -- & 346 & 117 & 133 & --. & 1,960 & 1,060 \\
\hline 3 & --. & --- & $\ldots$ & 329 & 176 & 117 & --- & 2,000 & 1,280 \\
\hline 4 & $\cdots$ & -- & $\cdots$ & 224 & 192 & 105 & --- & 1,850 & 2,060 \\
\hline 5 & --- & --- & -- & 238 & 174 & 115 & --- & 1,810 & 2,190 \\
\hline 6 & --- & -- & --. & 256 & 135 & --- & --- & 1,260 & 2,370 \\
\hline 7 & --- & -- & --- & 222 & 133 & -.- & 307 & 1,170 & 2,740 \\
\hline 8 & -- & -.. & $\ldots$ & 191 & 117 & -.. & 240 & 1,360 & 2,060 \\
\hline 9 & -.- & --- & $\ldots$ & 184 & 111 & --- & -.. & 1,360 & 2,940 \\
\hline 10 & --- & $\ldots$ & --- & 202 & 118 & -.- & 282 & 1,110 & 2,240 \\
\hline 11 & --. & -- & --- & 164 & 114 & -.. & 214 & 1,140 & 2,100 \\
\hline 12 & --- & -- & --- & 127 & 118 & -.. & 178 & 976 & 2,510 \\
\hline 13 & --- & $\ldots$ & --- & 197 & 121 & -.. & 248 & 949 & 2,680 \\
\hline 14 & $\ldots$ & -- & -.. & 208 & 119 & --- & 235 & 967 & 2,440 \\
\hline 15 & --- & --- & $\cdots$ & 200 & -- &.-- & 300 & 816 & 1,940 \\
\hline 16 & -- & --- & $\ldots$ & 137 & --- & --- & 288 & 687 & 2,110 \\
\hline 17 & --- & -- & -.- & 149 & --. & $-\cdots$ & 304 & 853 & 2,470 \\
\hline 18 & --- & $\cdots$ & --- & 138 & --- & --. & 459 & 1,210 & 2,510 \\
\hline 19 & $\cdots$ & --- & -.. & 193 & $\cdots$ & --. & 568 & 1,240 & 2,230 \\
\hline 20 & $\cdots$ & --- & $\cdots$ & 289 & --- & --- & 709 & 1,150 & 2,100 \\
\hline 21 & --. & $\ldots$ & -.- & 199 & -.. & --. & 594 & 1,550 & 2,440 \\
\hline 22 & --- & -.. & 336 & 229 & --- & --- & 829 & 1,920 & 2,670 \\
\hline 23 & 569 & --- & 225 & 220 & -.. & --- & 895 & 1,650 & 2,070 \\
\hline 24 & 531 & --- & 557 & 138 & --. & --- & 883 & 1,310 & 2,520 \\
\hline 25 & -- & $\cdots$ & 762 & 119 & 142 & --- & 1,200 & 1,070 & 2,240 \\
\hline 26 & $\ldots$ & --. & 685 & 110 & 145 & ... & 1,190 & 774 & 1,900 \\
\hline 27 & --- & -.. & 665 & 109 & 140 & --- & 1,240 & 759 & 2,140 \\
\hline 28 & --- & ..- & 989 & 110 & 183 & --. & 1,460 & 837 & 2,250 \\
\hline 29 & --- & $-\ldots$ & 976 & 109 & 188 & $\cdots$ & 1,440 & 567 & 2,660 \\
\hline 30 & -- & --- & 760 & 110 & 132 & --- & 1,580 & 494 & 2,810 \\
\hline 31 & --- & --- & 394 & -- & 152 & -.. & 1,830 & 915 & -- \\
\hline
\end{tabular}

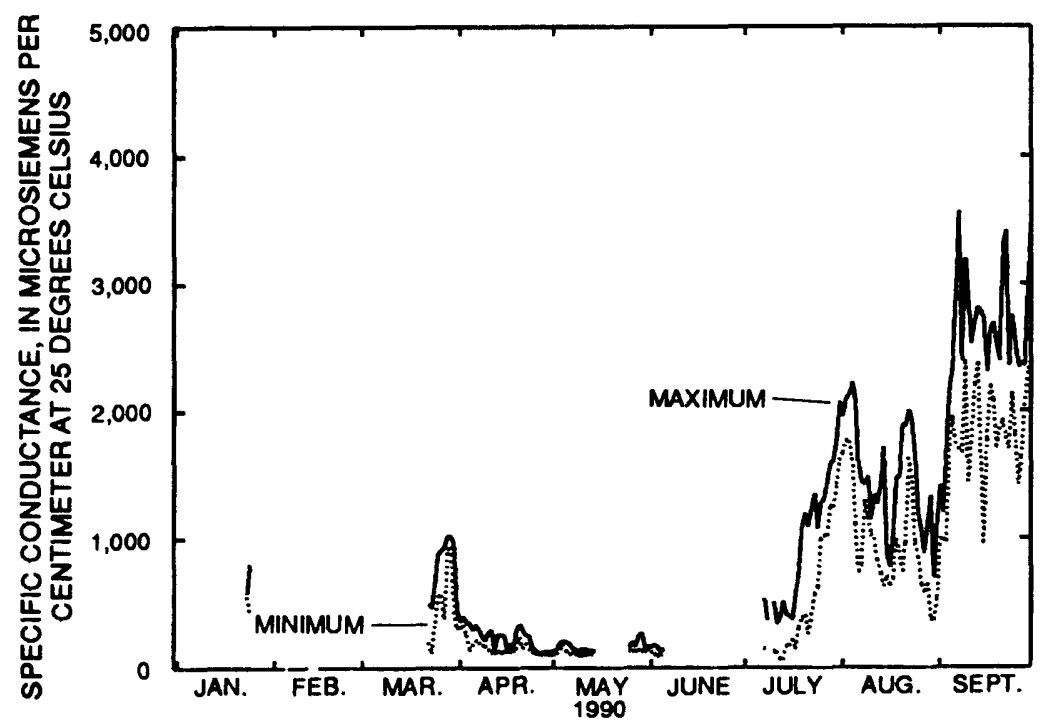


Table 30.--Daily mean values of specific conductance, near bottom, in water at site 3, Albemarle Sound at light 3,

October 1990 through May 1991

STATION NUMBER AND NAME: 0208115600, Albemarle Sound at light 3

LATITUDE: $36^{\circ} 00^{\prime} 06^{\prime \prime}$ LONGITUDE: 76'23'36" COUNTY: Washington

PROBE LOCATION: 2 feet above bottom

[Specific conductance, microsiemens per centimeter at 25 degrees Celsius; ---, no data]

\begin{tabular}{|c|c|c|c|c|c|c|c|c|}
\hline Day & Oct. & Nov. & Dec. & Jan. & Feb. & Mar. & Apr. & May \\
\hline 1 & 2,250 & 1,770 & 1,380 & 1,510 & -.. & 466 & 814 & 197 \\
\hline 2 & 2,130 & 1,310 & 1,450 & 1,630 & $\cdots$ & 474 & 494 & 168 \\
\hline 3 & 2,450 & 993 & 1,510 & 1,620 & ... & 415 & 836 & 130 \\
\hline 4 & 2,320 & 721 & 1,380 & 1,860 & -.- & 348 & 1,040 & 138 \\
\hline 5 & 2,160 & 626 & 906 & 1,670 & $\cdots$ & 353 & 568 & 159 \\
\hline 6 & 2,300 & 725 & 1,540 & 1,720 & $\cdots$ & 341 & -.. & 180 \\
\hline 7 & 2,260 & 1,380 & 1,100 & 1,570 & $\cdots$ & 430 & --- & --- \\
\hline 8 & 2,070 & 2,020 & 1,510 & 1,500 & $\ldots$ & 425 & --- & --- \\
\hline 9 & 2,130 & 2,500 & 1,300 & 745 & -.. & 616 & $\ldots$ & -.. \\
\hline 10 & 2,200 & 1,780 & 1,250 & $\ldots$ & 283 & 668 & --- & --- \\
\hline 11 & 3,280 & 998 & 1,260 & $\cdots$ & 277 & 426 & --- & -.- \\
\hline 12 & 2,790 & 730 & 1,360 & -.- & 252 & 452 & 543 & --. \\
\hline 13 & 2,360 & 891 & 1,330 & -.. & 257 & 402 & 571 & --. \\
\hline 14 & 2,420 & 1,250 & 1,640 & $\cdots$ & 242 & --- & 453 & --- \\
\hline 15 & 2,080 & 1,590 & 1,660 & --- & 240 & 327 & 621 & --- \\
\hline 16 & 2,450 & 952 & 1,310 & --- & 281 & 559 & 363 & --- \\
\hline 17 & 2,280 & 756 & 1,590 & -.- & 241 & 432 & 457 & --. \\
\hline 18 & 2,550 & 1,310 & 1,260 & --- & 282 & 401 & --- & ... \\
\hline 19 & 2,610 & 1,290 & 1,010 & --- & 257 & --. & 590 & --- \\
\hline 20 & 3,080 & 1,200 & 1,250 & --- & 271 & --- & 729 & --- \\
\hline 21 & 3,030 & 1,120 & 1,440 & ..- & 416 & -.- & 307 & $\ldots$ \\
\hline 22 & 2,820 & 1,060 & 1,250 & --- & 429 & --- & 474 & $\ldots$ \\
\hline 23 & 2,490 & 822 & 1,090 & --- & 622 & $\ldots$ & 571 & --- \\
\hline 24 & 1,690 & 798 & 917 & --. & 673 & --- & 462 & $\ldots$ \\
\hline 25 & 2,130 & 672 & 1,410 & --- & 729 & --- & 291 & --. \\
\hline 26 & 1,860 & 1,030 & 1,910 & --- & 573 & -.. & 320 & -.. \\
\hline 27 & 1,500 & 765 & 1,870 & --- & 499 & 772 & 377 & -.- \\
\hline 28 & 1,940 & 813 & 1,640 & --- & 438 & --. & 201 & --- \\
\hline 29 & 1,910 & 1,160 & 1,540 & --- & $\cdots$ & -.. & 168 & -.. \\
\hline 30 & 2,510 & 1,500 & 1,270 & --- & $\cdots$ & --. & 197 & --- \\
\hline 31 & 1,970 & --- & 931 & --- & $\cdots$ & 1,260 & --- & $\ldots$ \\
\hline
\end{tabular}

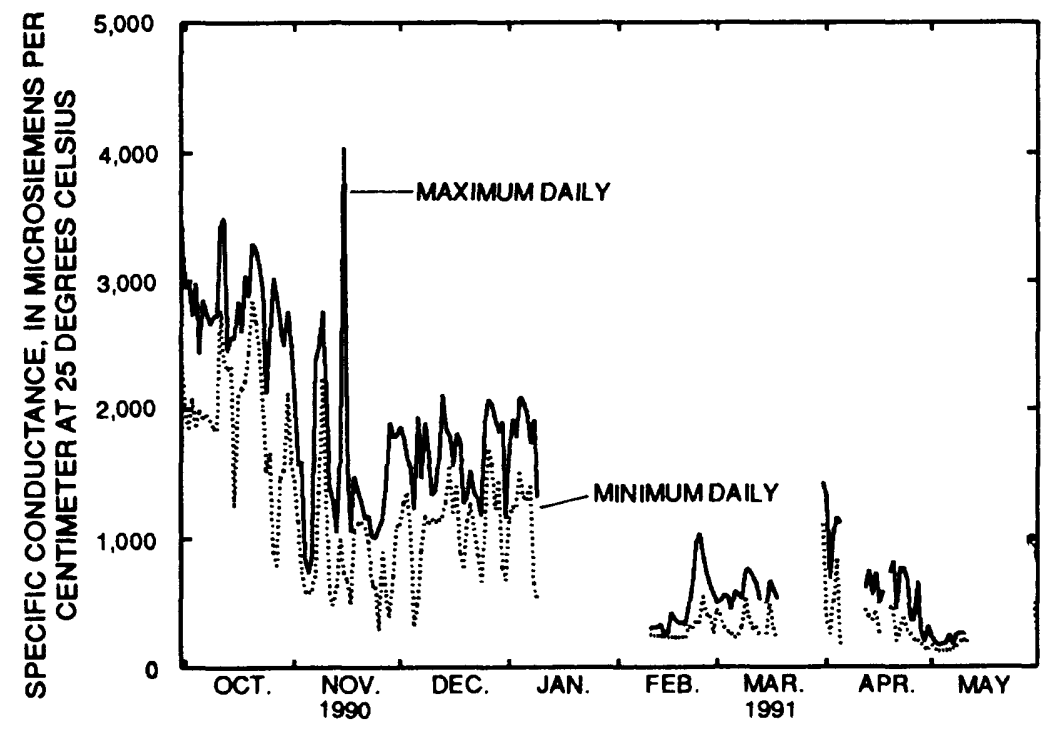


Table 31.--Daily mean values of salinity concentration, near bottom, in water at site 3, Albemarle Sound at light 3 , January through September 1990

STATION NUMBER AND NAME: 0208115600, Albemarle Sound at light 3 LATITUDE: $36^{\circ} 00^{\prime} 06^{\prime \prime}$ LONGITUDE: $76^{\circ} 23^{\prime} 36^{\prime \prime}$ COUNTY: Washington

PROBE LOCATION: 2 feet above bottom

[Salinity concentration, parts per thousand; ---, no data]

\begin{tabular}{|c|c|c|c|c|c|c|c|c|c|}
\hline Day & Jan. & Feb. & Mar. & Apr. & May & June & July & Aug. & Sept. \\
\hline 1 & --- & --- & --- & 0.14 & 0.05 & 0.06 & -.. & 0.90 & 0.53 \\
\hline 2 & --- & $\cdots$ & -.. & .15 & .05 & .05 & --- & .98 & .50 \\
\hline 3 & --- & --- & --- & .14 & .07 & .05 & --. & 1.0 & .62 \\
\hline 4 & -- & --- & --- & .09 & .08 & .04 & --- & .92 & 1.0 \\
\hline 5 & --- & --- & $\cdots$ & .10 & .07 & .05 & --. & .90 & 1.1 \\
\hline 6 & -.. & --- & --- & .11 & .05 & --- & -.- & .61 & 1.2 \\
\hline 7 & --- & $\ldots$ & --- & .09 & .05 & --- & 0.13 & .56 & 1.4 \\
\hline 8 & --. & --- & --. & .08 & .05 & --- & .10 & .67 & 1.0 \\
\hline 9 & --. & --. & --- & .07 & .04 & ... & -- & .66 & 1.5 \\
\hline 10 & -.- & -- & .-. & .08 & .05 & --- & .12 & .53 & 1.1 \\
\hline 11 & -.- & $\ldots$ & --- & .07 & .05 & --. & .09 & .55 & 1.1 \\
\hline 12 & --- & --. & --. & .05 & .05 & -.- & .07 & .46 & 1.3 \\
\hline 13 & $\ldots$ & --. & --- & .08 & .05 & -.- & .11 & .45 & 1.4 \\
\hline 14 & -.- & $\ldots$ & --- & .09 & .05 & --. & .10 & .46 & 1.2 \\
\hline 15 & --- & --- & --. & .08 & -- & -..- & .13 & .38 & .97 \\
\hline 16 & -.- & -.. & --- & .05 & -.. & -.. & .12 & .32 & 1.1 \\
\hline 17 & -.- & --- & -.. & .06 & --- & --. & .13 & .40 & 1.3 \\
\hline 18 & --. & -- & --- & .06 & -- & --. & .21 & .58 & 1.3 \\
\hline 19 & --- & -.. & --- & .08 & -.. & -.- & .26 & .60 & 1.1 \\
\hline 20 & --. & --- & --- & .12 & $\ldots$ & --- & .33 & .55 & 1.1 \\
\hline 21 & -.. & -.. & -.- & .08 & --. & --- & .27 & .76 & 1.2 \\
\hline 22 & --. & -.. & 0.15 & .09 & -.- & --. & .39 & .96 & 1.4 \\
\hline 23 & 0.26 & --. & .10 & .09 & --. & $\ldots$ & .42 & .82 & 1.0 \\
\hline 24 & .24 & -.. & .25 & .06 & -.- & -.- & .41 & .64 & 1.3 \\
\hline 25 & --- & --- & .35 & .05 & .06 & -.. & .58 & .51 & 1.1 \\
\hline 26 & --- & --- & .32 & .04 & .06 & --- & .58 & .36 & .95 \\
\hline 27 & --- & --- & .31 & .04 & .06 & --- & .60 & .35 & 1.1 \\
\hline 28 & --- & -- & .46 & .04 & .07 & --- & .72 & .39 & 1.1 \\
\hline 29 & --. & --. & .46 & .04 & .08 & ... & .71 & .26 & 1.4 \\
\hline 30 & --- & --- & .35 & .04 & .05 & --- & .78 & .22 & 1.4 \\
\hline 31 & -.. & --- & .18 & -.. & .06 & -.. & .91 & .43 & --. \\
\hline
\end{tabular}

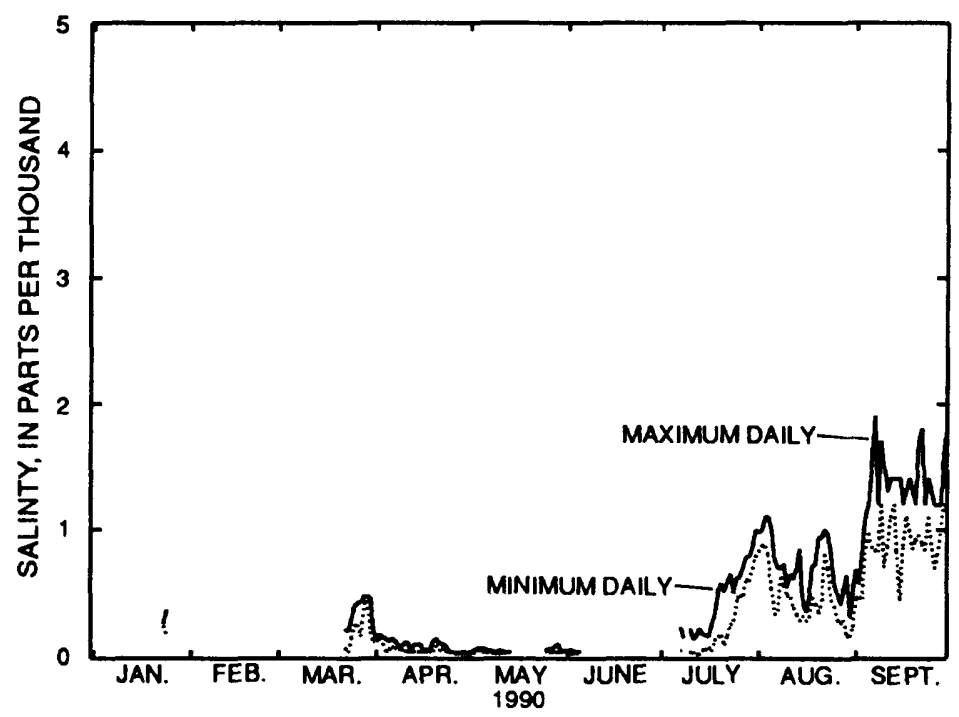


Table 32.--Daily mean values of salinity concentration, near bottom, in water at site 3, Albemarle Sound at light 3 , October 1990 through May 1991

STATION NUMBER AND NAME: 0208115600, Albemarle Sound at light 3 LATITUDE: $36^{\circ} 00^{\prime} 06^{\prime \prime}$ LONGITUDE: $76^{\circ} 23^{\prime} 36^{\prime \prime}$ COUNTY: Washington PROBE LOCATION: 2 feet above bottom

[Salinity concentration, parts per thousand; ---, no data]

\begin{tabular}{|c|c|c|c|c|c|c|c|c|}
\hline Day & Oct. & Nov. & Dec. & Jan. & Feb. & Mar. & Apr. & May \\
\hline 1 & 1.1 & 0.88 & 0.68 & 0.74 & -.- & 0.21 & 0.38 & 0.08 \\
\hline 2 & 1.1 & .64 & .71 & .81 & --- & .21 & .22 & .07 \\
\hline 3 & 1.2 & .47 & .74 & .80 & -.- & .19 & .39 & .05 \\
\hline 4 & 1.2 & .33 & .68 & .93 & $\cdots$ & .15 & .49 & .06 \\
\hline 5 & 1.1 & .29 & .43 & .82 & -- & .16 & .26 & .06 \\
\hline 6 & 1.2 & .34 & .76 & .85 & --. & .15 & --- & .07 \\
\hline 7 & 1.1 & .67 & .53 & .77 & $\cdots$ & .19 & $\cdots$ & $\cdots$ \\
\hline 8 & 1.0 & 1.0 & .74 & .74 & $\ldots$ & .19 & $\ldots$ & --- \\
\hline 9 & 1.1 & 1.3 & .63 & .35 & $\cdots$ & .28 & $\cdots$ & $\cdots$ \\
\hline 10 & 1.1 & .88 & .61 & --- & 0.12 & .31 & --- & --- \\
\hline 11 & 1.7 & .47 & .61 & $\cdots$ & .12 & .19 & -- & -.. \\
\hline 12 & 1.4 & .34 & .66 & --. & .11 & .20 & .25 & --- \\
\hline 13 & 1.2 & .42 & .65 & --- & .11 & .18 & .26 & $\cdots$ \\
\hline 14 & 1.2 & .60 & .81 & --- & .10 & --- & .20 & --- \\
\hline 15 & 1.0 & .79 & .82 & --- & .10 & .14 & .29 & $\cdots$ \\
\hline 16 & 1.2 & .45 & .64 & $\cdots$ & .12 & .26 & .16 & -.. \\
\hline 17 & 1.2 & .35 & .79 & --- & .10 & .19 & .21 & --- \\
\hline 18 & 1.3 & .64 & .61 & --- & .12 & .18 & -- & --- \\
\hline 19 & 1.3 & .63 & .48 & --- & .11 & --- & .27 & --- \\
\hline 20 & 1.6 & .58 & .61 & --- & .12 & $\cdots$ & .34 & -- \\
\hline 21 & 1.6 & .54 & .71 & --- & .19 & -.- & .13 & -- \\
\hline 22 & 1.4 & .50 & .61 & --- & .19 & -.- & .21 & --- \\
\hline 23 & 1.3 & .38 & .52 & --- & .29 & --- & .26 & --. \\
\hline 24 & .84 & .37 & .43 & --- & .31 & --- & .21 & --. \\
\hline 25 & 1.1 & .31 & .69 & --- & .34 & $\cdots$ & .13 &.-- \\
\hline 26 & .93 & .49 & .96 & --- & .26 & --- & .14 & --- \\
\hline 27 & .74 & .36 & .93 & --- & .23 & .36 & .17 & -- \\
\hline 28 & .97 & .39 & .81 & $\cdots$ & .20 & --- & .08 & --- \\
\hline 29 & .96 & .56 & .76 & -- & --- & --- & .07 & $\cdots$ \\
\hline 30 & 1.3 & .74 & .62 & --- & --- & --- & .08 & $\cdots$ \\
\hline 31 & .99 & --- & .44 & --- & --. & .61 & --- & $\cdots$ \\
\hline
\end{tabular}

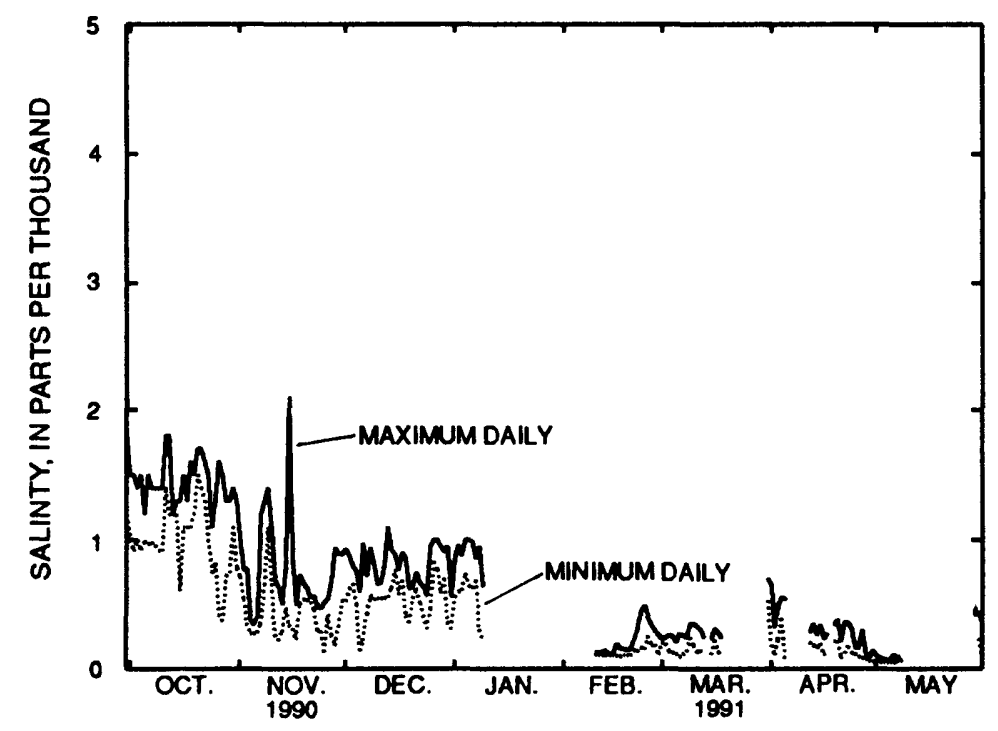


Table 33.--Daily mean values of water temperature, near surface, in water at site 3, Albemarle Sound at light 3, January through September 1990

STATION NUMBER AND NAME: 0208115600, Albemarle Sound at light 3 LATITUDE: $36^{\circ} 00^{\prime} 06^{\prime \prime}$ LONGITUDE: 76²3'36" COUNTY: Washington PROBE LOCATION: 7 feet above bottom

[Water temperature, degrees Celsius; ---, no data]

\begin{tabular}{|c|c|c|c|c|c|c|c|c|c|}
\hline Day & Jan. & Feb. & Mar. & Apr. & May & June & July & Aug. & Sept. \\
\hline 1 & -.. & --- & --- & 15.8 & 21.5 & 21.6 &.-- & 29.0 & 27.2 \\
\hline 2 & -.- & --- & --- & 16.2 & 21.7 & 22.2 & -- & 28.8 & 27.4 \\
\hline 3 & -.. & --- & -.- & 16.1 & 21.0 & 22.5 & --- & 28.6 & 27.1 \\
\hline 4 & --- & -- & --- & 15.8 & 21.0 & 23.1 & --- & 28.7 & 26.5 \\
\hline 5 & -- & $\cdots$ & $\cdots$ & 16.0 & 21.7 & 22.5 & --. & 28.7 & 26.4 \\
\hline 6 & --- & --- & -.. & 16.6 & 21.2 & --- & --- & 28.1 & 26.6 \\
\hline 7 & $\ldots$ & --- & $\cdots$ & 16.1 & 21.0 & $\ldots$ & 29.2 & 27.6 & 26.7 \\
\hline 8 & --- & -.- & 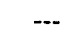 & 15.7 & 20.9 & --- & 29.3 & 27.4 & 26.5 \\
\hline 9 & --- & --- & --- & 15.9 & 21.2 & ..- & -- & 27.3 & 25.9 \\
\hline 10 & -- & $\cdots$ & $\cdots$ & 16.4 & 21.3 & --- & 29.2 & 27.4 & 26.3 \\
\hline 11 & -- & --- & --. & 16.8 & 20.7 & -- & 29.3 & 28.2 & 26.4 \\
\hline 12 & --- & --- & --- & --- & 20.8 & --- & 29.5 & 28.5 & 26.4 \\
\hline 13 & -.. & --- & $\cdots$ & -.. & 21.0 & $\cdots$ & 29.2 & 28.2 & 26.4 \\
\hline 14 & -.- & -- & --- & 15.8 & 21.5 & -- & 28.8 & 27.9 & 26.4 \\
\hline 15 & -.- & -- & --- & 16.5 & --- & --- & 28.4 & 27.9 & 26.2 \\
\hline 16 & $\cdots$ & -- & --. & 16.9 & -.- & $\cdots$ & 28.4 & 28.0 & 26.4 \\
\hline 17 & -- & $\cdots$ & --- & 17.5 & -.- & -- & 28.4 & 27.9 & 25.5 \\
\hline 18 & -- & --- & --- & 16.9 & --- & -.- & 28.5 & 28.4 & 24.2 \\
\hline 19 & 6.3 & -.- & --- & 16.4 & --- & --- & 28.6 & 28.6 & 23.0 \\
\hline 20 & 7.1 & --- & $\cdots$ & 16.5 & --- & --- & 28.6 & 28.5 & 23.1 \\
\hline 21 & 7.4 & ... & --- & 16.5 & -.. & -- & 28.6 & 28.1 & 22.9 \\
\hline 22 & 7.5 & --- & 18.2 & 17.0 & -.- & --- & 29.2 & 27.9 & 22.9 \\
\hline 23 & 7.8 & --. & 18.9 & 17.8 & --. & --- & 29.8 & 27.7 & 23.0 \\
\hline 24 & 8.5 & --- & 18.3 & 18.2 & --- & -- & 29.3 & 27.7 & 22.2 \\
\hline 25 & 9.8 & --- & 17.5 & 18.6 & 21.9 & -- & 28.9 & 28.0 & 22.3 \\
\hline 26 & 9.9 & $\ldots$ & 17.1 & 19.4 & 21.3 & --- & 28.4 & 27.7 & 21.8 \\
\hline 27 & 9.2 & --- & 16.8 & 21.1 & 20.8 & --- & 28.3 & 28.5 & 22.0 \\
\hline 28 & 9.1 & --. & 16.2 & 20.7 & 20.2 & ..- & 28.1 & 28.7 & 21.8 \\
\hline 29 & 9.6 & --- & 15.8 & 21.1 & 20.8 & -.- & 28.3 & 28.9 & 22.0 \\
\hline 30 & 10.1 & --- & 15.7 & 20.9 & 20.8 & --- & 28.5 & 28.3 & 22.0 \\
\hline 31 & --- & --. & 15.8 & ... & 20.7 & $\ldots$ & 28.9 & 27.4 & - \\
\hline
\end{tabular}

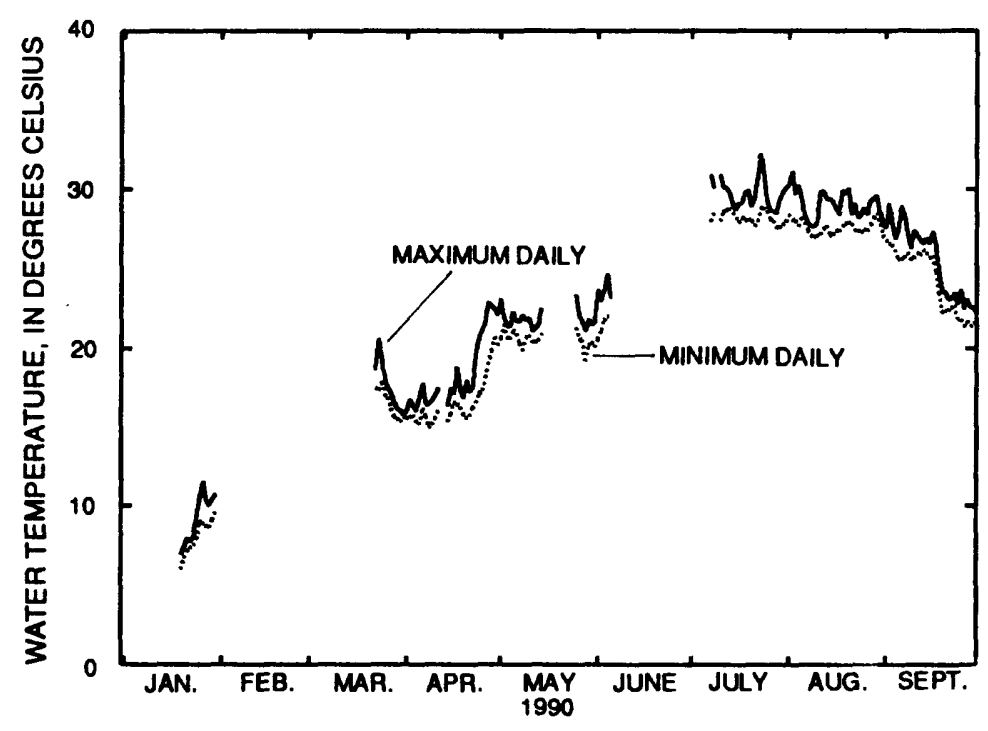


Table 34.--Daily mean values of water temperature, near surface, in water at site 3, Albemarle Sound at light 3, October 1990 through May 1991

STATION NUMBER AND NAME: 0208115600, Albemarle Sound at light 3 LATITUDE: $36^{\circ} 00^{\prime} 06^{\prime \prime}$ LONGITUDE: 76'23'36" COUNTY: Washington PROBE LOCATION: 7 feet above bottom

[Water temperature, degrees Celsius; ---, no data]

\begin{tabular}{|c|c|c|c|c|c|c|c|c|}
\hline Day & Oct. & Nov. & Dec. & Jan. & Feb. & Mar. & Apr. & May \\
\hline 1 & 21.9 & 16.3 & 11.0 & 10.0 & --- & 8.6 & 14.2 & 21.3 \\
\hline 2 & 22.0 & 16.0 & 11.4 & 9.6 & ... & 9.6 & 14.5 & 20.8 \\
\hline 3 & 21.9 & 16.6 & 11.6 & 9.4 & --- & 10.7 & 14.2 & 20.8 \\
\hline 4 & 21.9 & 16.5 & 12.2 & 9.4 & -.. & 10.6 & 14.2 & 20.4 \\
\hline 5 & 22.3 & 16.7 & 11.2 & 9.0 & --. & 10.5 & 14.8 & 20.4 \\
\hline 6 & 22.2 & 17.2 & 10.1 & 9.0 & -.- & 10.7 & 15.8 & 21.1 \\
\hline 7 & 22.8 & 16.9 & 10.3 & 9.2 & --- & 10.8 & 16.9 & -.. \\
\hline 8 & 22.9 & 16.3 & 10.2 & 8.7 & ... & 10.6 & 16.9 & -.. \\
\hline 9 & 23.4 & 15.5 & 9.6 & 8.4 & --- & 10.1 & 18.0 & --. \\
\hline 10 & 23.2 & --- & 9.1 & -- & 8.4 & 10.0 & 17.9 & --. \\
\hline 11 & 22.9 & -.. & 9.1 & --- & 8.4 & 9.6 & 17.5 & --- \\
\hline 12 & 23.1 & -.. & 9.3 & --- & 8.1 & 9.4 & 17.1 & --. \\
\hline 13 & 23.6 & --. & 9.5 & --- & 8.1 & 9.3 & 16.8 & $\ldots$ \\
\hline 14 & 24.3 & -.. & 9.5 & -.- & 9.0 & -.. & 16.8 & --- \\
\hline 15 & 24.1 & --- & 9.2 & --. & 8.7 & 8.7 & 17.5 & -.. \\
\hline 16 & 23.5 & -.. & 9.5 & -.. & 7.3 & 8.9 & 17.8 & -.. \\
\hline 17 & 22.9 & 12.8 & 9.5 & --- & 5.5 & 9.2 & 18.6 & ... \\
\hline 18 & 22.7 & 12.0 & 9.9 & $\ldots$ & 6.3 & 9.8 & $\ldots$ & -.. \\
\hline 19 & 21.8 & 11.5 & 10.4 & --- & 7.0 & 9.7 & 17.8 & --- \\
\hline 20 & 20.8 & 11.4 & 10.0 & --- & 8.1 & 10.0 & 17.2 & -.- \\
\hline 21 & 20.4 & 11.3 & 10.7 & --- & 8.7 & 10.6 & 16.7 & $\ldots$ \\
\hline 22 & 20.6 & 11.4 & 11.1 & -.. & 9.4 & 11.3 & 15.8 & -.- \\
\hline 23 & 20.7 & 11.3 & 12.1 & $\ldots$ & 8.4 & 11.8 & 16.3 & -.. \\
\hline 24 & 20.8 & 11.4 & 12.0 & --. & 8.1 & 12.5 & 17.0 & $\ldots$ \\
\hline 25 & 20.4 & 11.2 & 11.1 & --- & 8.4 & 13.0 & 17.2 & -.. \\
\hline 26 & 18.8 & 11.8 & 10.2 & --- & 8.1 & 12.9 & 17.3 & --. \\
\hline 27 & 17.6 & 11.6 & 9.6 & -.. & 7.9 & 13.8 & 18.2 & --. \\
\hline 28 & 16.6 & 12.4 & 9.2 & -.. & 7.9 & 14.4 & 18.8 & -.- \\
\hline 29 & 16.1 & 12.7 & 9.3 & $\cdots$ & $\ldots$ & 15.0 & 19.3 & ... \\
\hline 30 & 15.7 & 11.6 & 9.9 & --- & -.. & 15.1 & 20.1 & --- \\
\hline 31 & 15.8 & --- & 10.9 & $\cdots$ & -- & 14.2 & --- & --- \\
\hline
\end{tabular}

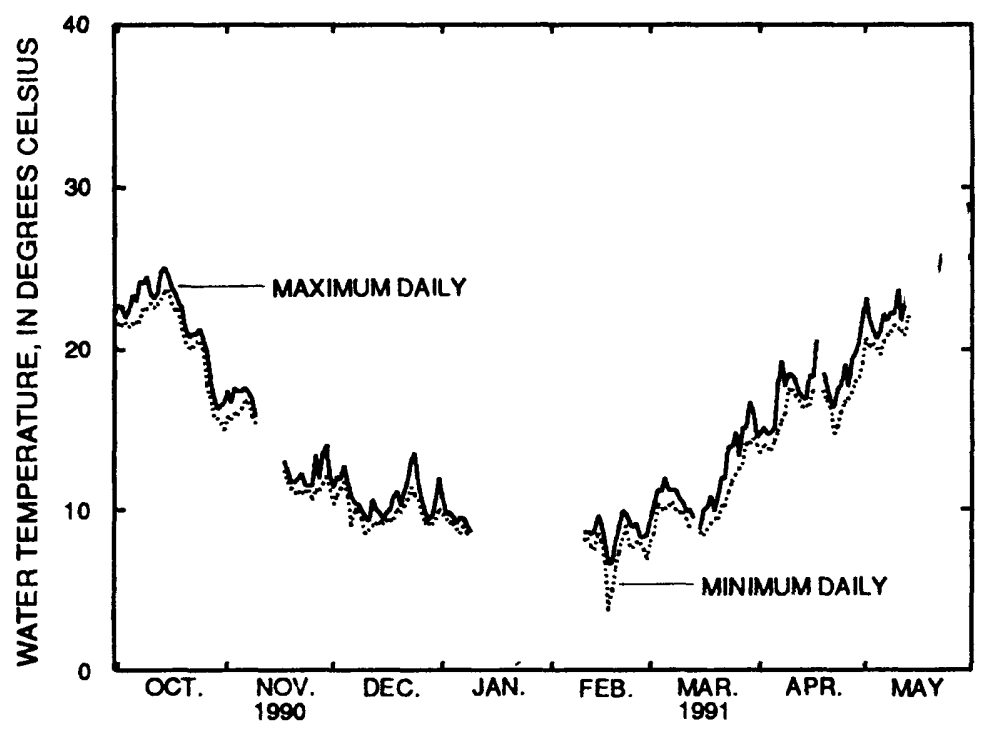


Table 35.--Daily mean values of dissolved-oxygen concentration, near surface, in water at site 3, Albemarle Sound at light 3 , January through September 1990

STATION NUMBER AND NAME: 0208115600, Albemarle Sound at light 3 LATITUDE: $36^{\circ} 00^{\prime} 06^{\prime \prime}$ LONGITUDE: 76²3'36" COUNTY: Washington PROBE LOCATION: 7 feet above bottom

[Dissolved-oxygen concentration, milligrams per liter; ---, no data]

\begin{tabular}{|c|c|c|c|c|c|c|c|c|c|}
\hline Day & Jan. & Feb. & Mar. & Apr. & May & June & July & Aug. & Sept. \\
\hline 1 & --- & --- & --- & --- & 9.7 & 9.6 & --- & 8.0 & 7.9 \\
\hline 2 & --- & --. & -.. & -.- & 9.3 & 9.3 & --- & 8.1 & 8.1 \\
\hline 3 & --- & $\cdots$ & --- & --- & 8.8 & 9.1 & -- & 7.9 & 7.7 \\
\hline 4 & --- & -.- & --- & --- & 8.7 & 9.4 & --- & 7.8 & 7.5 \\
\hline 5 & $\cdots$ & --- & --- & --- & 8.7 & 9.5 & $\cdots$ & 7.9 & 7.9 \\
\hline 6 & --- & -- & --- & --- & 8.7 & $\cdots$ & --- & 7.3 & 7.8 \\
\hline 7 & --- & $\cdots$ & --- & --. & 8.9 & --- & 7.3 & 7.0 & 7.3 \\
\hline 8 & --- & --- & --- & --- & 9.2 & --- & 7.0 & 7.2 & 7.0 \\
\hline 9 & $--\cdot$ & --- & --- & $\cdots$ & 8.9 & --- & --- & 7.3 & 6.6 \\
\hline 10 & --- & -- & --- & --- & 8.6 & -- & 7.5 & 7.5 & 6.7 \\
\hline 11 & --- & --- & --- & --. & 8.6 & --- & 7.2 & 7.9 & 6.6 \\
\hline 12 & --- & --- & --- & --- & 8.8 & --- & 7.0 & 8.1 & 6.7 \\
\hline 13 & --- & --- & --- & --- & 8.8 & --. & 6.9 & 8.8 & 6.4 \\
\hline 14 & --- & -- & --- & $\cdots$ & 8.7 & --- & 6.9 & 9.4 & 6.4 \\
\hline 15 & $\cdots$ & --- & $\cdots$ & $\cdots$ & --- & --- & 7.1 & 9.3 & 6.3 \\
\hline 16 & $\cdots$ & --- & -- & -- & --- & --- & 7.4 & 9.1 & 6.6 \\
\hline 17 & --- & $--\cdot$ & 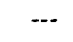 & --- & --- & --- & 7.4 & 9.1 & 6.7 \\
\hline 18 & $\cdots$ & -- & -- & --- & --- & --- & 7.5 & 9.4 & 6.8 \\
\hline 19 & 11.2 & $\cdots$ & --- & --- & $\cdots$ & -- & 7.7 & 9.6 & 7.0 \\
\hline 20 & $11.2=$ & --- & $\cdots$ & $\cdots$ & --- & --- & 7.3 & 9.0 & 6.9 \\
\hline 21 & 11.1 & --- & --. & --- & --- & --- & 7.0 & 8.6 & 6.7 \\
\hline 22 & 11.2 & -- & 10.4 & --- & --- & $\ldots$ & 7.5 & 9.1 & 6.6 \\
\hline 23 & 11.2 & -- & 10.5 & -- & --- & --- & 8.0 & 8.5 & 6.7 \\
\hline 24 & 11.0 & $\cdots$ & 10.5 & 9.3 & --- & --- & 7.6 & 8.5 & 6.8 \\
\hline 25 & 10.8 & -- & 10.5 & 9.2 & 8.2 & --- & 7.4 & 8.6 & 7.1 \\
\hline 26 & 10.8 & --- & 10.5 & 9.3 & 8.3 & --- & 7.3 & 8.1 & 6.6 \\
\hline 27 & 10.9 &..- & 10.6 & 9.9 & 7.9 & $\cdots$ & 7.5 & 8.6 & 6.7 \\
\hline 28 & 11.0 & $\cdots$ & 10.8 & 9.5 & 8.0 & --- & 7.5 & 8.3 & 6.5 \\
\hline 29 & 10.8 & $\cdots$ & 10.8 & 9.4 & 8.1 & --- & 7.7 & 8.1 & 6.5 \\
\hline 30 & 10.8 & $\cdots$ & 10.8 & 9.4 & 8.3 & $--\cdot$ & 8.1 & 7.5 & 6.3 \\
\hline 31 & --- & -- & 10.5 & --- & 8.9 & $\cdots$ & 8.3 & 7.7 & -- \\
\hline
\end{tabular}

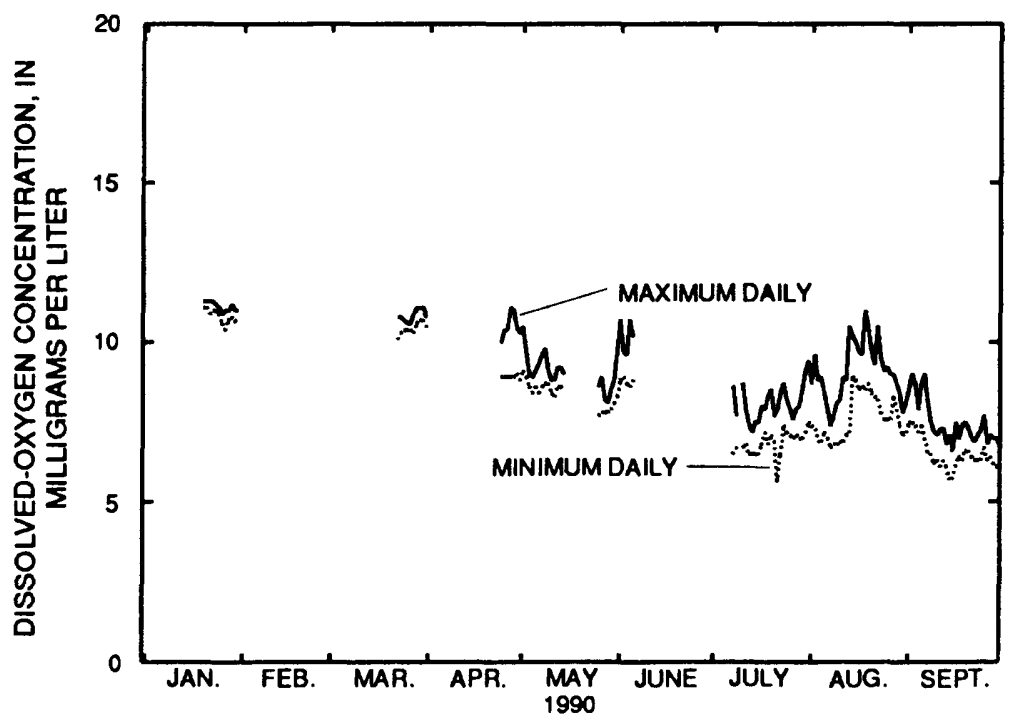


Table 36.--Daily mean values of dissolved-oxygen concentration, near surface, in water at site 3, Albemarle Sound at light 3 , October 1990 through May 1991

STATION NUMBER AND NAME: 0208115600, Albemarle Sound at light 3 LATITUDE: $36^{\circ} 00^{\prime} 06^{\prime \prime}$ LONGITUDE: $76^{\circ} 23^{\prime} 36^{\prime \prime}$ COUNTY: Washington PROBE LOCATION: 7 feet above bottom

[Dissolved-oxygen concentration, milligrams per liter; -..-, no data]

\begin{tabular}{|c|c|c|c|c|c|c|c|c|}
\hline Day & Oct. & Nov. & Dec. & Jan. & Feb. & Mar. & Apr. & May \\
\hline 1 & 6.3 & 10.0 & 9.9 & 10.4 & --- & 13.5 & 11.1 & 9.9 \\
\hline 2 & 6.3 & 9.4 & 9.9 & 10.5 & --- & 13.5 & 10.7 & 9.2 \\
\hline 3 & 7.7 & 9.7 & 10.0 & 10.5 & -.. & 13.2 & 11.0 & 9.3 \\
\hline 4 & 8.0 & 9.6 & 9.8 & 10.7 & -.. & 13.1 & 11.3 & 8.9 \\
\hline 5 & 7.6 & 9.6 & 9.9 & 10.6 & -.. & 13.2 & 10.7 & 8.8 \\
\hline 6 & 7.6 & 9.8 & 10.1 & 10.7 & --- & 13.1 & 10.3 & 8.6 \\
\hline 7 & 7.8 & 9.8 & 10.1 & 10.7 & --. & 13.1 & 10.2 & ... \\
\hline 8 & 7.9 & 9.8 & 10.2 & 10.7 & --. & 13.2 & 9.8 & --. \\
\hline 9 & 7.8 & 10.0 & 10.3 & 10.7 & $\ldots$ & 13.3 & 9.4 & --- \\
\hline 10 & 7.4 & 10.1 & 10.6 & $\ldots$ & 12.3 & 13.5 & 9.2 & --- \\
\hline 11 & 7.3 & 10.3 & 10.5 & $\ldots$ & 12.3 & 13.5 & 9.2 & --- \\
\hline 12 & 7.5 & 10.5 & 10.6 & -- & 12.4 & 13.7 & 9.2 & -.. \\
\hline 13 & 7.7 & 10.3 & 10.6 & -- & 12.5 & 13.8 & 9.1 & --- \\
\hline 14 & 8.5 & 10.3 & 10.5 & $\ldots$ & 12.4 & -- & 8.9 & -.- \\
\hline 15 & 8.5 & 10.7 & 10.6 & $\cdots$ & 12.4 & 14.0 & 9.1 & $\ldots$ \\
\hline 16 & 8.5 & 10.3 & 10.5 & -- & 12.8 & 14.2 & 8.6 & -- \\
\hline 17 & 8.3 & 9.6 & 10.6 & -.. & 13.5 & 14.1 & 8.9 & -.. \\
\hline 18 & 8.2 & 9.9 & 10.5 & -.. & 13.2 & 14.0 & --- & --- \\
\hline 19 & 8.0 & 10.1 & 10.3 & -.. & 13.4 & 13.5 & 9.0 & --- \\
\hline 20 & 8.2 & 10.2 & 10.3 & --- & 13.3 & 13.5 & 9.0 & --. \\
\hline 21 & 8.3 & 10.1 & 10.4 & --- & 13.2 & 13.5 & 9.0 & --- \\
\hline 22 & 8.1 & 10.4 & 10.4 & -- & 13.1 & 13.1 & 9.3 & -.. \\
\hline 23 & 7.9 & 9.9 & 10.2 & $\ldots$ & 13.2 & 12.9 & 9.5 & -.. \\
\hline 24 & 7.8 & 9.9 & 9.9 & --. & 13.2 & 12.6 & 9.5 & --- \\
\hline 25 & 8.0 & 9.8 & 10.0 & --. & 13.4 & 12.3 & 9.5 & -- \\
\hline 26 & 8.3 & 10.0 & 10.2 & -- & 13.3 & 12.2 & 9.6 & -.. \\
\hline 27 & 8.7 & 9.8 & 10.4 & --- & 13.4 & 11.9 & 9.8 & -.. \\
\hline 28 & 9.1 & 9.5 & 10.6 & -.. & 13.6 & 11.5 & 9.5 & --. \\
\hline 29 & 9.2 & 9.3 & 10.7 & $\cdots$ & $\ldots$ & 11.2 & 9.7 & --- \\
\hline 30 & 9.5 & 9.5 & 10.8 & $\ldots$ & -.. & 10.8 & 9.9 & --- \\
\hline 31 & 9.9 & ... & 10.3 & --- & --- & 11.0 & --. & --. \\
\hline
\end{tabular}

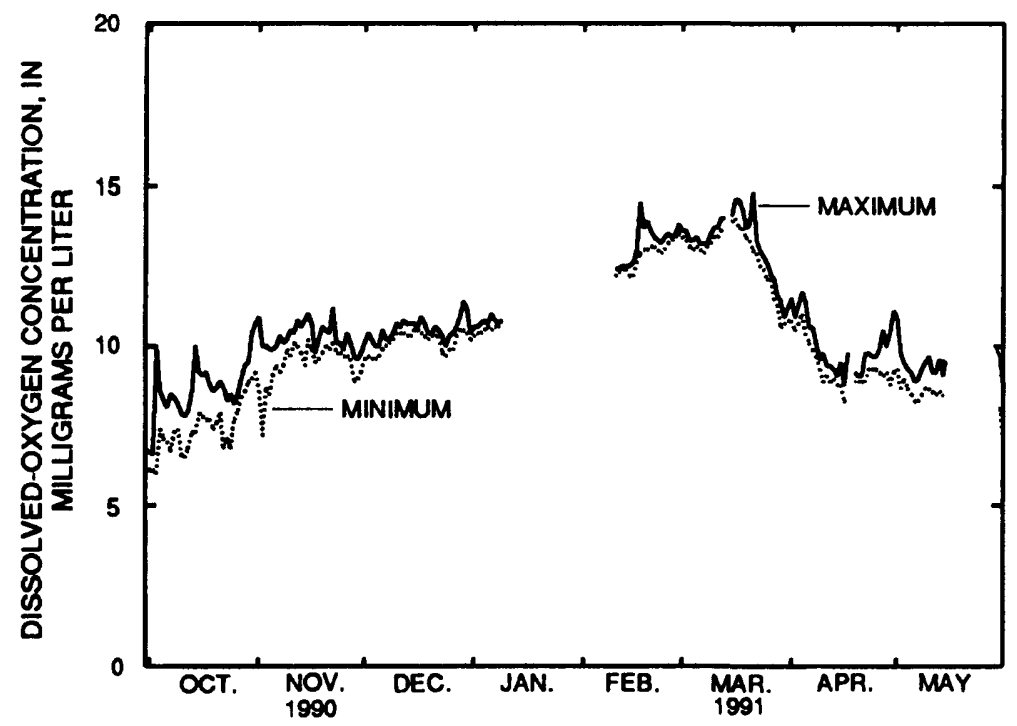


Table 37.--Daily mean values of dissolved-oxygen concentration, mid-depth, in water at site 3, Albemarle Sound at light 3, January through September 1990

STATION NUMBER AND NAME: 0208115600, Albemarle Sound at light 3

LATITUDE: $36^{\circ} 00^{\prime} 06^{\prime \prime}$ LONGITUDE: 76'23'36". COUNTY: Washington PROBE LOCATION: 5 feet above bottom

[Dissolved-oxygen concentration, milligrams per liter; -.-, no data]

\begin{tabular}{|c|c|c|c|c|c|c|c|c|c|}
\hline Day & Jan. & Feb. & Mar. & Apr. & May & June & July & Aug. & Sept. \\
\hline 1 & $\cdots$ & ... & -.- & 9.3 & 9.3 & 9.5 & -.- & -.- & -.. \\
\hline 2 & $\cdots$ & --. & --- & 9.3 & 9.2 & 9.2 & $\cdots$ & -.. & --- \\
\hline 3 & -.- & --- & --- & 9.3 & 8.7 & 9.0 & -.- & -... & -.- \\
\hline 4 & -- & --- & --- & 9.3 & 8.6 & 9.2 & $\cdots$ & $\cdots$ & -- \\
\hline 5 & --- & --. & --. & 9.4 & 8.7 & 9.3 & --- & $-\ldots$ & $\cdots$ \\
\hline 6 & --- & --- & --- & 9.3 & 8.7 & --- & --- & 6.0 & --. \\
\hline 7 & $\cdots$ & $\cdots$ & --. & 9.3 & 8.9 & $\cdots$ & 7.6 & 5.5 & $\cdots$ \\
\hline 8 & --- & --. & --. & 9.4 & 9.0 & --- & 7.4 & 5.8 & $\cdots$ \\
\hline 9 & -.. & --- & -- & 9.4 & 8.6 & $\cdots$ & $\cdots$ & 6.3 & $\cdots$ \\
\hline 10 & --- & --. & -- & 9.5 & 8.3 & -.- & 7.7 & 6.7 & -.. \\
\hline 11 & --- & -- & -- & 9.3 & 8.4 & --- & 7.6 & 7.1 & --- \\
\hline 12 & $\cdots$ & $\cdots$ & $\cdots$ & 9.3 & 8.7 & $\cdots$ & 7.4 & 7.7 & -- \\
\hline 13 & --- & $\cdots$ & $\cdots$ & 9.3 & 8.6 & --- & 7.4 & -- & --- \\
\hline 14 & --- & $\cdots$ & $\cdots$ & 9.3 & 8.5 & --- & 7.4 & --- & --- \\
\hline 15 & --- & -- & -- & 9.3 & --- & $\cdots$ & 7.6 & -- & $\cdots$ \\
\hline 16 & --- & --- & -.- & 9.2 & --- & --- & 7.8 & --. & -.. \\
\hline 17 & --. & --- & -.- & 9.2 & --. & --. & 7.9 & --- & -- \\
\hline 18 & --- & --- & -- & 9.1 & -- & -.. & 8.0 & --. & --- \\
\hline 19 & 11.6 & $\cdots$ & $\cdots$ & 9.3 & $\cdots$ & $\cdots$ & 8.0 & $\cdots$ & -- \\
\hline 20 & 11.2 & -- & $-\cdot$ & 9.7 & -- & --- & 7.6 & -- & $\cdots$ \\
\hline 21 & 11.1 & $\cdots$ & -- & 9.4 & $\cdots$ & $\cdots$ & 7.3 & $\ldots$ & -- \\
\hline 22 & 11.1 & $\cdots$ & 9.1 & 9.7 & $\cdots$ & $\cdots$ & 7.7 & $\cdots$ & $\cdots$ \\
\hline 23 & 11.1 & -- & 9.2 & 9.7 & -- & --. & 7.9 & -- & --- \\
\hline 24 & 11.0 & $\cdots$ & 9.3 & 9.1 & -- & --- & 7.6 & $\cdots$ & -- \\
\hline 25 & 10.9 & --- & 9.3 & 8.9 & 8.5 & $\cdots$ & 7.5 & -- & -.- \\
\hline 26 & 10.8 & $\cdots$ & 9.4 & 9.0 & 8.6 & --- & 7.5 & $\cdots$ & --- \\
\hline 27 & 10.9 & $\cdots$ & 9.5 & 9.4 & 8.3 & --- & 7.6 & -- & -- \\
\hline 28 & 10.9 & -- & 9.8 & 9.1 & 8.4 & --- & 7.7 & --. & --. \\
\hline 29 & 10.9 & $\cdots$ & 9.7 & 9.1 & 8.4 & --- & 7.8 & --. & -- \\
\hline 30 & 10.8 & $\cdots$ & 9.7 & 9.1 & 8.5 & --- & 8.1 & $\cdots$ & --- \\
\hline 31 & --- & $-\cdots$ & 9.5 & $\cdots$ & 9.0 & --. & 8.4 & -- & -- \\
\hline
\end{tabular}

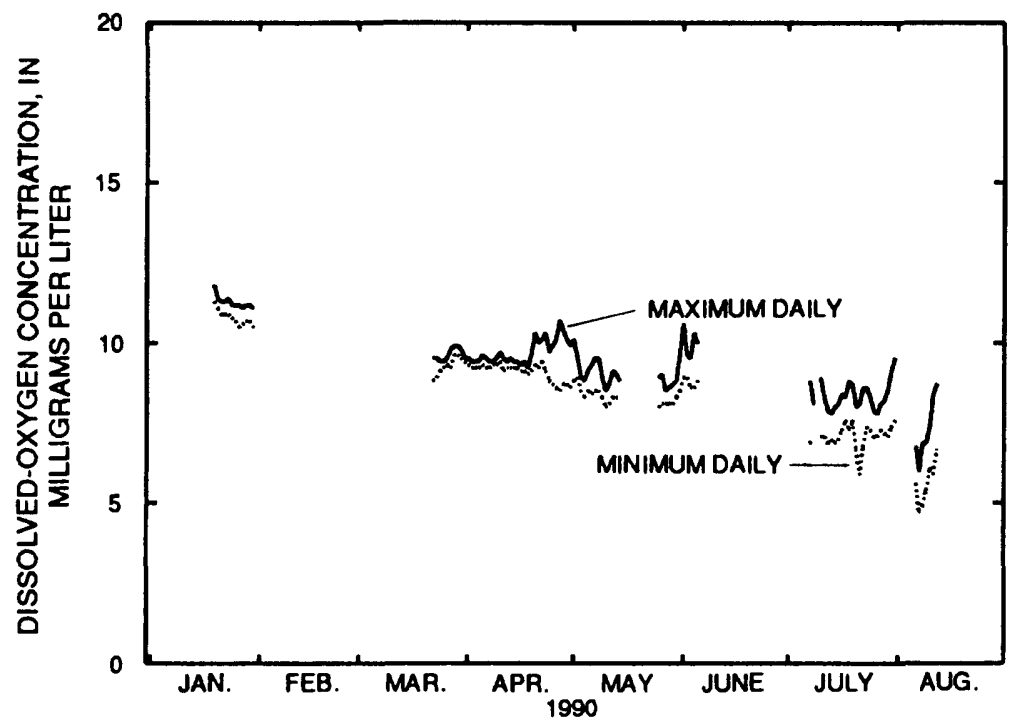


Table 38.--Daily mean values of dissolved-oxygen concentration, mid-depth, in water at site 3, Albemarle Sound at light 3, October 1990 through May 1991

STATION NUMBER AND NAME: 0208115600, Albemarle Sound at light 3 LATITUDE: $36^{\circ} 00^{\prime} 06^{\prime \prime}$ LONGITUDE: $76^{\circ} 23^{\prime} 36^{\prime \prime}$ COUNTY: Washington

PROBE LOCATION: 5 feet above bottom

[Dissolved-oxygen concentration, milligrams per liter; ---, no data]

\begin{tabular}{|c|c|c|c|c|c|c|c|c|}
\hline Day & Oct. & Nov. & Dec. & Jan. & Feb. & Mar. & Apr. & May \\
\hline 1 & --- & 10.9 & 8.2 & -.. & -.. & 13.2 & --- & 9.8 \\
\hline 2 & --- & 10.6 & -.- & -.- & --- & 13.2 & -.. & 9.2 \\
\hline 3 & --- & 10.5 & --- & --- & --. & 13.0 & --- & 9.3 \\
\hline 4 & 9.6 & 10.4 & --- & --- & --- & 12.8 & --. & 9.0 \\
\hline 5 & 9.7 & 10.3 & --- & --- & --. & 12.9 & $\cdots$ & 8.8 \\
\hline 6 & 9.6 & 10.2 & --- & --- & --. & 12.9 & -.- & 8.6 \\
\hline 7 & 9.8 & 10.2 & $\cdots$ & -.. & ... & 12.9 & ... & --- \\
\hline 8 & 9.9 & 10.1 & -.. & -.- & --- & 12.9 & --- & \\
\hline 9 & 9.6 & 10.3 & -- & --- & --. & 13.0 & ... & -.- \\
\hline 10 & 9.0 & 10.3 & --- & --- & 12.0 & 13.2 & $\cdots$ & -- \\
\hline 11 & 8.7 & 10.4 & $\ldots$ & --. & 12.0 & 13.3 & --- & --. \\
\hline 12 & 8.7 & 10.5 & -.. & -.- & 12.0 & 13.5 & $\ldots$ & ... \\
\hline 13 & 8.5 & 10.3 & --- & --- & 12.1 & 13.5 & -.. & --- \\
\hline 14 & 9.3 & 10.3 &.-- & --. & 12.0 & --- & -.. & --. \\
\hline 15 & 9.7 & 10.6 & --- & --- & 12.0 & 13.5 & -- & --- \\
\hline 16 & 9.6 & 9.9 & --- & --. & 12.4 & 13.7 & -- & --- \\
\hline 17 & 9.3 & 9.1 & -- & --- & 13.1 & 13.6 & -- & -- \\
\hline 18 & 9.4 & 9.2 & --- & --- & 12.9 & --- & -.. & --. \\
\hline 19 & 9.3 & 9.4 & -.. & -- & 13.0 & $\cdots$ & 8.8 & --- \\
\hline 20 & 9.7 & 9.5 & -.- & --- & 13.0 & --. & 8.9 & --- \\
\hline 21 & 10.0 & 9.4 & -.. & --- & 12.8 & $\ldots$ & 8.9 & --- \\
\hline 22 & 9.8 & 9.6 & -.- & --. & 12.9 & -.. & 9.2 & -- \\
\hline 23 & 9.3 & 9.1 & -.. & --- & 12.8 & --- & 9.4 & --- \\
\hline 24 & 9.2 & 9.1 & $-\ldots$ & --. & 12.9 & --- & 9.4 & -- \\
\hline 25 & 8.9 & 9.0 & -- &.-- & 13.0 & --- & 9.3 & -- \\
\hline 26 & 9.0 & 9.1 & --- & ... & 13.0 & --- & 9.5 & --. \\
\hline 27 & 9.2 & 8.9 & -- & $\ldots$ & 13.1 & --- & 9.7 & -- \\
\hline 28 & 9.8 & 8.6 & -- & -- & 13.3 & --- & 9.3 & -.- \\
\hline 29 & 10.0 & 8.2 & --. & -- & --- & --- & 9.5 & -- \\
\hline 30 & 10.4 & 8.1 & --- & --- & --. & --- & 9.7 & -- \\
\hline 31 & 10.8 & --- & --. & --- & --. & --. & -- & --- \\
\hline
\end{tabular}

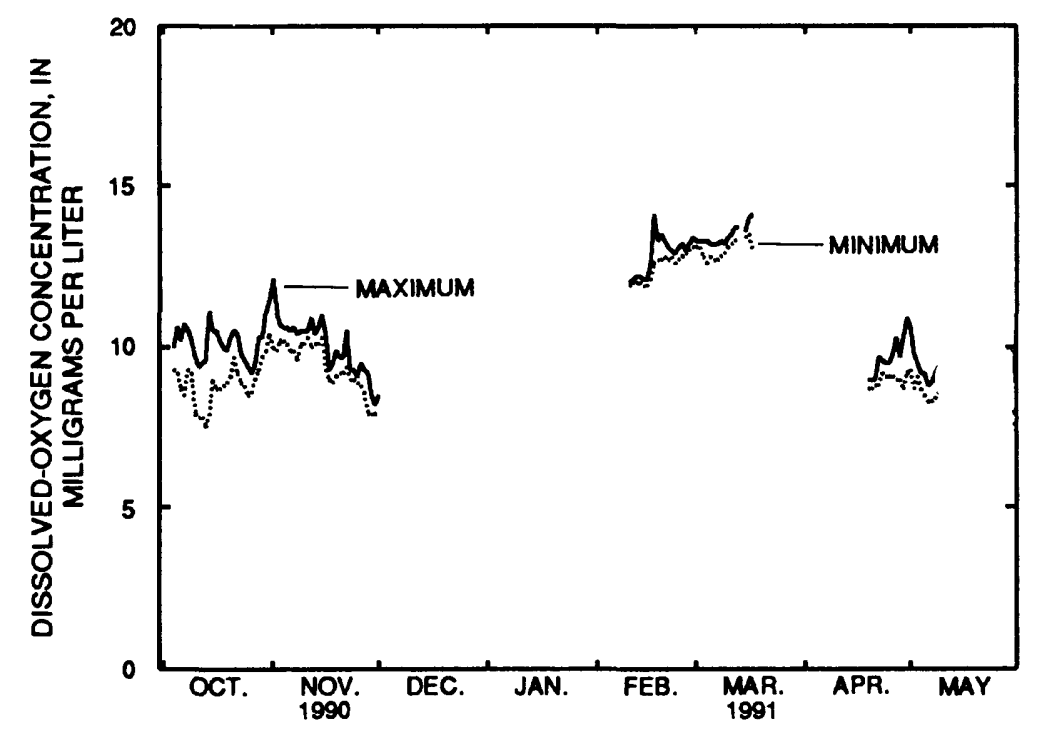


Table 39.--Daily mean values of dissolved-oxygen concentration, near bottom, in water at site 3, Albemarle Sound at light 3, January through September 1990

STATION NUMBER AND NAME: 0208115600, Albemarle Sound at light 3 LATITUDE: $36^{\circ} 00^{\prime} 06^{\prime \prime}$ LONGITUDE: 76'23'36" COUNTY: Washington PROBE LOCATION: 2 feet above bottom

[Dissolved-oxygen concentration, milligrams per liter; ---, no data]

\begin{tabular}{|c|c|c|c|c|c|c|c|c|c|}
\hline Day & Jan. & Feb. & Mar. & Apr. & May & June & July & Aug. & Sept. \\
\hline 1 & --- & -- & $\ldots$ & 11.9 & 11.7 & 10.8 & -.- & 8.3 & 9.1 \\
\hline 2 & --- & -- & -- & 11.7 & 11.3 & 10.5 & -.- & 8.3 & 8.9 \\
\hline 3 & --- & --- & --. & 11.8 & 10.9 & 10.0 & -- & 8.3 & 8.9 \\
\hline 4 & --- & -.- & -.- & 11.7 & 10.5 & 9.7 & --- & 7.8 & 8.9 \\
\hline 5 & $\cdots$ & -- & -- & 11.6 & 9.9 & 9.4 & --- & 8.0 & 8.9 \\
\hline 6 & $\ldots$ & --- & --- & 11.5 & 9.3 & --- & -.- & 8.1 & 8.7 \\
\hline 7 & --- & --- & $\cdots$ & 11.4 & 8.8 & -- & 4.3 & 6.7 & 8.4 \\
\hline 8 & $\cdots$ & -- & -- & 11.4 & 7.3 & --- & 5.5 & 6.4 & 8.4 \\
\hline 9 & -- & -- & $\cdots$ & 11.3 & 8.6 & $\cdots$ & $\cdots$ & 7.4 & 8.4 \\
\hline 10 & $\cdots$ & --- & $\cdots$ & 11.2 & 8.7 & -- & 4.3 & 8.1 & 8.4 \\
\hline 11 & --- & $\cdots$ & -.- & 11.1 & 8.8 & $\ldots$ & 5.4 & 8.0 & 8.5 \\
\hline 12 & --- & $\ldots$ & --- & 11.0 & 8.8 & --- & 5.8 & 8.0 & 8.5 \\
\hline 13 & -- & -- & $\cdots$ & 11.0 & 9.0 & $\cdots$ & 5.8 & 7.6 & 8.4 \\
\hline 14 & -- & $\cdots$ & --- & 10.9 & 9.0 & --- & 6.2 & 7.9 & 8.2 \\
\hline 15 & --- & $\cdots$ & $\cdots$ & 10.7 & -- & -- & 6.9 & 7.6 & 8.3 \\
\hline 16 & --- & --- & --- & 10.6 & -.. & $\cdots$ & 8.0 & 8.5 & 8.3 \\
\hline 17 & --- & $\cdots$ & --- & 10.5 & -- & $\cdots$ & 8.0 & 9.9 & 8.2 \\
\hline 18 & --- & --- & $\ldots$ & 10.5 & -- & --- & 8.3 & 10.0 & 8.3 \\
\hline 19 & 11.3 & $\ldots$ & $\cdots$ & 10.4 & -.. & $\cdots$ & 8.4 & 10.0 & 8.4 \\
\hline 20 & 11.1 & $\cdots$ & $\cdots$ & 10.3 & -. & $\cdots$ & 8.2 & 10.0 & 8.3 \\
\hline 21 & 10.8 & --- & $\cdots$ & 10.2 & $\cdots$ & $\cdots$ & 6.9 & 9.7 & 8.2 \\
\hline 22 & 10.8 & $\cdots$ & 11.0 & 10.1 & $\cdots$ & --. & 5.8 & 9.4 & 8.0 \\
\hline 23 & 10.8 & -- & 11.5 & 9.7 & -- & -- & 7.0 & 8.8 & 8.0 \\
\hline 24 & 10.6 & $\ldots$ & 11.6 & 8.9 & $\ldots$ & --- & 7.0 & 8.8 & 7.7 \\
\hline 25 & 10.3 & -- & 11.8 & 10.2 & 10.3 & -- & 6.8 & 9.2 & 7.8 \\
\hline 26 & 10.3 & -- & 11.9 & 12.8 & 11.1 & --- & 7.0 & 9.7 & 7.7 \\
\hline 27 & 10.3 & -- & 12.0 & 13.1 & 11.5 & --- & 7.3 & 9.8 & 7.6 \\
\hline 28 & 10.3 & $\cdots$ & 12.2 & 13.0 & 11.6 & $\cdots$ & 7.7 & 9.6 & 7.4 \\
\hline 29 & 10.1 & $\cdots$ & 12.2 & 12.6 & 11.5 & $\cdots$ & 8.6 & 9.5 & 7.1 \\
\hline 30 & 10.4 & -.- & 12.0 & 12.2 & 11.2 & $\cdots$ & 8.1 & 9.4 & 6.9 \\
\hline 31 & --- & --- & 11.8 & -- & 11.0 & -- & 8.3 & 9.3 & $\cdots$ \\
\hline
\end{tabular}

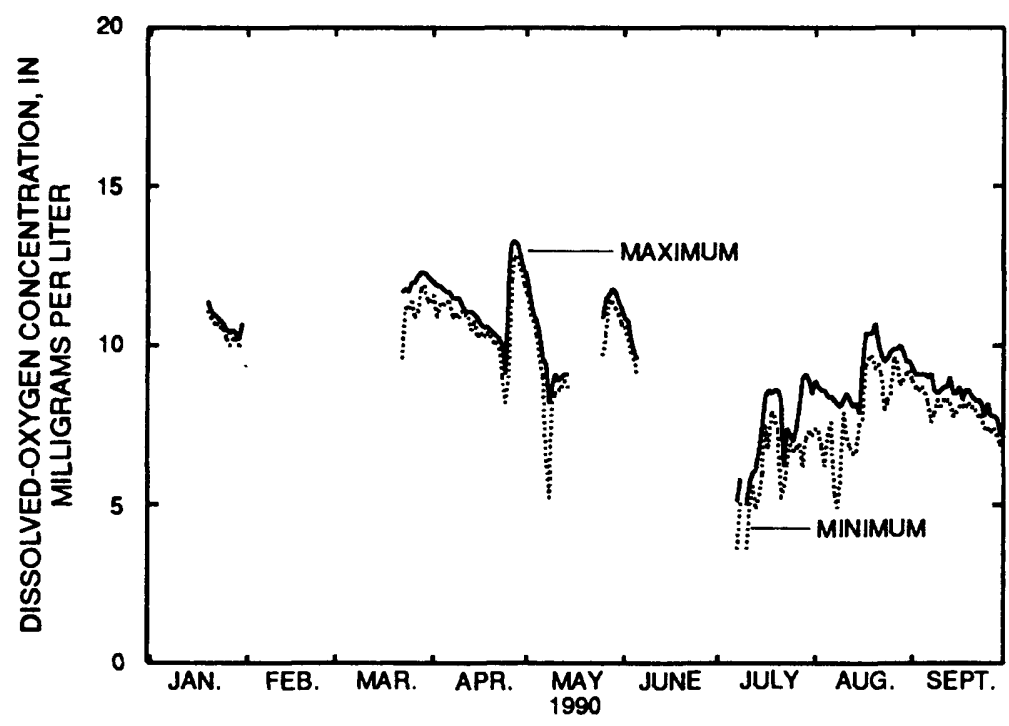


Table 40.--Daily mean values of dissolved-oxygen concentration, near bottom, in water at site 3, Albemarle Sound at light 3 , October 1990 through May 1991

STATION NUMBER AND NAME: 0208115600, Albemarle Sound at light 3 LATITUDE: $36^{\circ} 00^{\circ} 06^{\prime \prime}$ LONGITUDE: $76^{\circ} 23^{\prime} 36^{\prime \prime}$ COUNTY: Washington PROBE LOCATION: 2 feet above bottom

[Dissolved-oxygen concentration, milligrams per liter; ---, no data]

\begin{tabular}{|c|c|c|c|c|c|c|c|c|}
\hline Day & Oct. & Nov. & Dec. & Jan. & Feb. & Mar. & Apr. & May \\
\hline 1 & 7.0 & 9.4 & 13.1 & 11.5 & -.. & ... & --. & -- \\
\hline 2 & 7.0 & 10.4 & 13.0 & 10.6 & -.- & -.. & ... & 8.9 \\
\hline 3 & 8.1 & 10.9 & 13.1 & 10.2 & -.. & ... & $\ldots$ & 9.0 \\
\hline 4 & 9.3 & 11.1 & 13.1 & 11.0 & --. & --- & --- & 8.7 \\
\hline 5 & 8.8 & 11.4 & 13.3 & 11.0 & -.. & --. & -- & 8.5 \\
\hline 6 & 8.3 & 10.8 & 12.9 & 10.2 & --- & $-\cdots$ & ... & 8.6 \\
\hline 7 & 7.9 & 10.7 & 12.9 & 10.7 & -- & --- & -. & --- \\
\hline 8 & 7.8 & 10.8 & 13.3 & 11.4 & ... & ... & $\ldots$ & \\
\hline 9 & 7.9 & 11.2 & 13.4 & 11.3 & -.. & --- & - & -- \\
\hline 10 & 7.4 & 12.0 & 13.4 & ... & -.. & --. & --. & --- \\
\hline 11 & 7.8 & 13.0 & 13.4 & --- & -.- & -.- & --- & -- \\
\hline 12 & 8.5 & 13.1 & 12.7 & $\cdots$ & -.- & -.. & --- & --- \\
\hline 13 & 8.1 & 11.7 & 12.9 & -- & --. & --. & ..- & -- \\
\hline 14 & 8.8 & 10.7 & 12.9 & -.- & -.- & -- & --- & -- \\
\hline 15 & 10.1 & 10.4 & 12.6 & $\ldots$ & -.. & 10.7 & --- & $\cdots$ \\
\hline 16 & 11.0 & 10.5 & 12.8 & --- & -.. & 5.2 & --- & -- \\
\hline 17 & 11.0 & 11.0 & 12.4 & -.. & ... & 5.6 & ... & $\cdots$ \\
\hline 18 & 11.0 & 11.2 & 12.6 & --- & ..- & 6.3 & -- & -- \\
\hline 19 & 11.2 & 11.1 & 12.5 & $\cdots$ & -- & 6.7 & 8.7 & -- \\
\hline 20 & 11.2 & 11.9 & 12.5 & $\ldots$ & --- & 6.9 & 8.9 & -- \\
\hline 21 & 11.2 & 12.4 & 12.1 & -.- & -.- & 6.9 & 8.9 & -- \\
\hline 22 & 10.7 & 13.0 & 11.7 & -.- & -.. & 7.0 & 9.4 & ... \\
\hline 23 & 10.5 & 13.4 & 11.5 & --- & -.. & 7.0 & 9.8 & --- \\
\hline 24 & 10.5 & 13.5 & 11.7 &.-- & -.. & 7.1 & 9.8 & -- \\
\hline 25 & 10.3 & 13.7 & 11.6 & -.- & $\cdots$ & 7.1 & 9.4 & --- \\
\hline 26 & 10.4 & 13.5 & 11.0 & -- & --- & 7.4 & 9.7 & -.. \\
\hline 27 & 9.4 & 13.5 & 11.6 & --- & $\cdots$ & $\cdots$ & 9.9 & -- \\
\hline 28 & 10.1 & 13.2 & 11.4 & -.. & -.- & --- & 9.3 & -- \\
\hline 29 & 7.2 & 13.2 & 10.9 & -- & --. & $\cdots$ & 9.4 & -- \\
\hline 30 & 8.0 & 13.3 & 10.8 & $\cdots$ & -- & --- & 9.8 & $\cdots$ \\
\hline 31 & 8.1 & $\cdots$ & 11.3 & -- & -- & $\cdots$ & $\cdots$ & -- \\
\hline
\end{tabular}

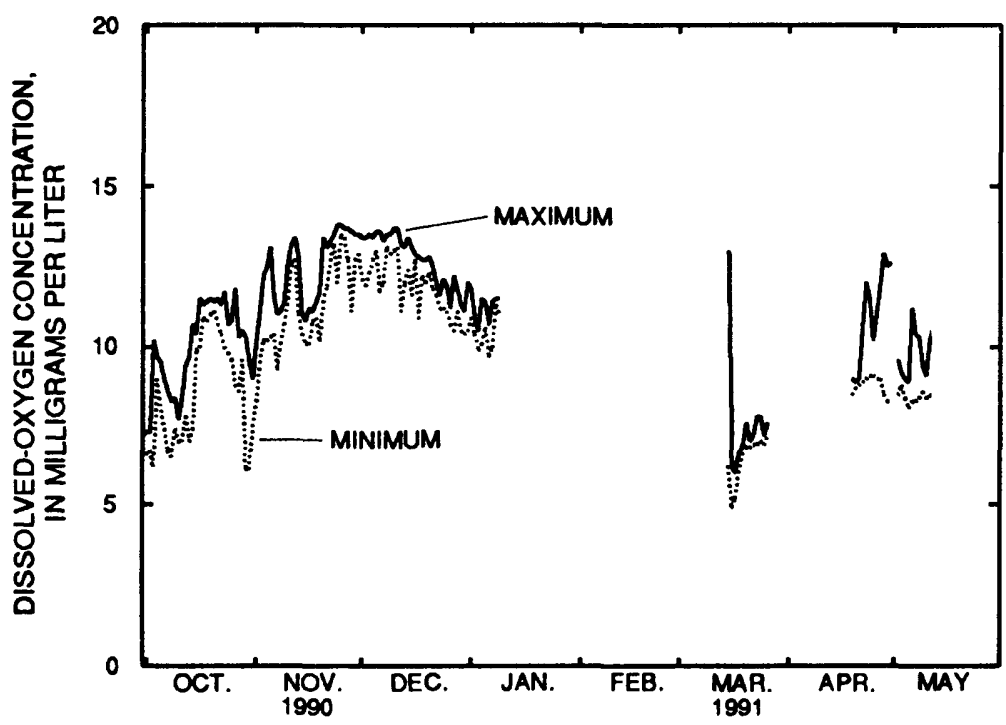


Table 41.--Daily mean values of specific conductance, near surface, in water at site 4, Pasquotank River at light 1 , January through May 1991

STATION NUMBER AND NAME: 0204387900, Pasquotank River at light 1

LATITUDE: $36^{\circ} 09^{\prime} 06^{\prime \prime}$ LONGITUDE: $76^{\circ} 01^{\prime} 18^{\prime \prime}$ COUNTY: Camden

PROBE LOCATION: 8 feet above bottom

[Specific conductance, microsiemens per centimeter at 25 degrees Celsius; --., no data]

\begin{tabular}{|c|c|c|c|c|c|}
\hline Day & Jan. & Feb. & Mar. & Apr. & May \\
\hline 1 & -.- & 3,960 & 2,570 & 4,480 & 2,170 \\
\hline 2 & -- & 4,220 & 2,900 & 4,420 & 2,320 \\
\hline 3 & $\cdots$ & 4,010 & 2,920 & 4,660 & 2,460 \\
\hline 4 & --- & 4,220 & 3,080 & 4,060 & 2,500 \\
\hline 5 & --. & 4,240 & 3,540 & 4,140 & 2,250 \\
\hline 6 & -.- & 4,220 & 3,730 & 3,770 & 2,210 \\
\hline 7 & $\ldots$ & 4,190 & 3,620 & 3,450 & 2,330 \\
\hline 8 & --- & 4,180 & 3,590 & 3,460 & --. \\
\hline 9 & -.- & 4,180 & 3,310 & 3,500 & -- \\
\hline 10 & -- & 4,030 & 4,970 & 3,470 & - \\
\hline 11 & --- & 3,560 & 4,510 & 3,740 & -- \\
\hline 12 & --- & 3,650 & 4,440 & 3,650 & -.- \\
\hline 13 & $\ldots$ & 3,650 & 4,020 & 3,820 & -.. \\
\hline 14 & $\cdots$ & 3,180 & 4,090 & 3,650 & -.. \\
\hline 15 & -- & 3,310 & 4,470 & 3,200 & -- \\
\hline 16 & --- & 3,930 & 4,400 & 3,310 & 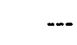 \\
\hline 17 & -- & 3,280 & 4,290 & 3,470 & -- \\
\hline 18 & 4,980 & 2,630 & 4,320 & 3,330 & -.- \\
\hline 19 & 4,680 & 2,880 & 4,550 & 2,650 & $\cdots$ \\
\hline 20 & 4,530 & 3,060 & 4,720 & 3,460 & --- \\
\hline 21 & 4,810 & 3,280 & 4,880 & 2,150 & -- \\
\hline 22 & 5,070 & 3,290 & 4,580 & 1,430 & -.. \\
\hline 23 & 4,910 & 3,640 & 4,590 & 961 & -- \\
\hline 24 & 4,170 & 3,320 & 5,000 & 1,040 & -.. \\
\hline 25 & 5,450 & 3,280 & 5,090 & 1,360 & -.- \\
\hline 26 & 4,560 & 3,250 & 5,390 & 1,350 & -- \\
\hline 27 & 4,070 & 3,080 & 4,920 & 1,600 & ... \\
\hline 28 & 2,730 & 2,650 & 4,760 & 1,710 & -- \\
\hline 29 & 2,340 & -.. & 5,470 & 1,650 & $\ldots$ \\
\hline 30 & 2,730 & --- & 5,510 & 1,780 & -.. \\
\hline 31 & 3,820 & --. & 5,000 & -- & --- \\
\hline
\end{tabular}

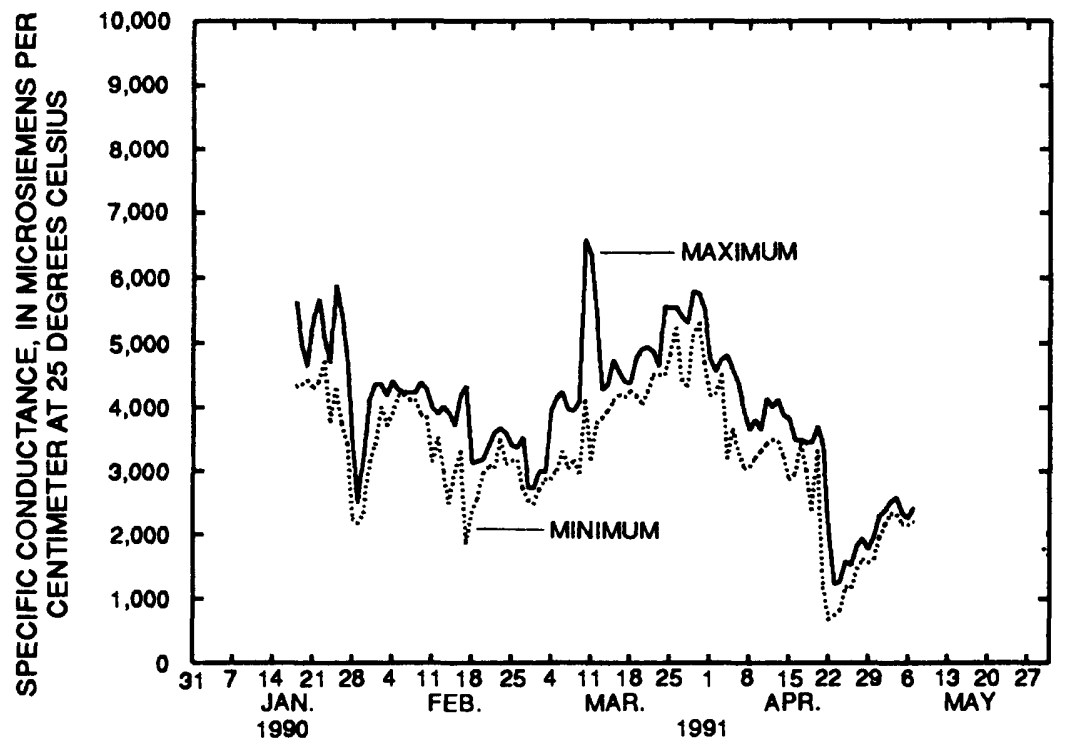


Table 42.--Daily mean values of salinity concentration, near surface, in water at site 4, Pasquotank River at light 1 , January through May 1991

STATION NUMBER AND NAME: 0204387900, Pasquotank River at light 1 LATITUDE: 36 09'06" LONGITUDE: 76 01'18" COUNTY: Camden PROBE LOCATION: 8 feet above bottom

[Salinity concentration, parts per thousand; ---, no data]

$\begin{array}{ccrrrr}\text { Day } & \text { Jan. } & \text { Feb. } & \text { Mar. } & \text { Apr. } & \text { May } \\ 1 & --- & 2.1 & 1.3 & 2.4 & 1.1 \\ 2 & --. & 2.2 & 1.5 & 2.3 & 1.2 \\ 3 & -.- & 2.1 & 1.5 & 2.5 & 1.2 \\ 4 & --- & 2.2 & 1.6 & 2.1 & 1.3 \\ 5 & -.- & 2.2 & 1.8 & 2.2 & 1.1\end{array}$

$\begin{array}{rrrrrr}6 & -- & 2.2 & 1.9 & 2.0 & 1.1 \\ 7 & -- & 2.2 & 1.9 & 1.8 & 1.2 \\ 8 & --- & 2.2 & 1.9 & 1.8 & -- \\ 9 & --- & 2.2 & 1.7 & 1.8 & -- \\ 10 & --- & 2.1 & 2.7 & 1.8 & ---\end{array}$

$\begin{array}{llllll}11 & -.- & 1.9 & 2.4 & 2.0 & -- \\ 12 & --- & 1.9 & 2.3 & 1.9 & --- \\ 13 & --- & 1.9 & 2.1 & 2.0 & -- \\ 14 & --- & 1.6 & 2.1 & 1.9 & -- \\ 15 & --- & 1.7 & 2.4 & 1.7 & --\end{array}$

$\begin{array}{llllll}16 & --- & 2.1 & 2.3 & 1.7 & --- \\ 17 & --- & 1.7 & 2.3 & 1.8 & -- \\ 18 & 2.7 & 1.3 & 2.3 & 1.7 & -- \\ 19 & 2.5 & 1.5 & 2.4 & 1.4 & -- \\ 20 & 2.4 & 1.6 & 2.5 & 1.8 & ---\end{array}$

\begin{tabular}{|c|c|c|c|c|}
\hline 21 & 2.6 & 1.7 & 2.6 & 1.1 \\
\hline 22 & 2.7 & 1.7 & 2.4 & .7 \\
\hline 23 & 2.6 & 1.9 & 2.4 & .5 \\
\hline 24 & 2.2 & 1.7 & 2.7 & .5 \\
\hline 25 & 2.9 & 1.7 & 2.7 & .7 \\
\hline 26 & 2.4 & 1.7 & 2.9 & .7 \\
\hline 27 & 2.1 & 1.6 & 2.6 & .8 \\
\hline 28 & 1.4 & 1.4 & 2.5 & .8 \\
\hline 29 & 1.2 & ... & 2.9 & .8 \\
\hline 30 & 1.4 & --. & 3.0 & .9 \\
\hline 31 & 2.0 & --. & 2.7 & --- \\
\hline
\end{tabular}

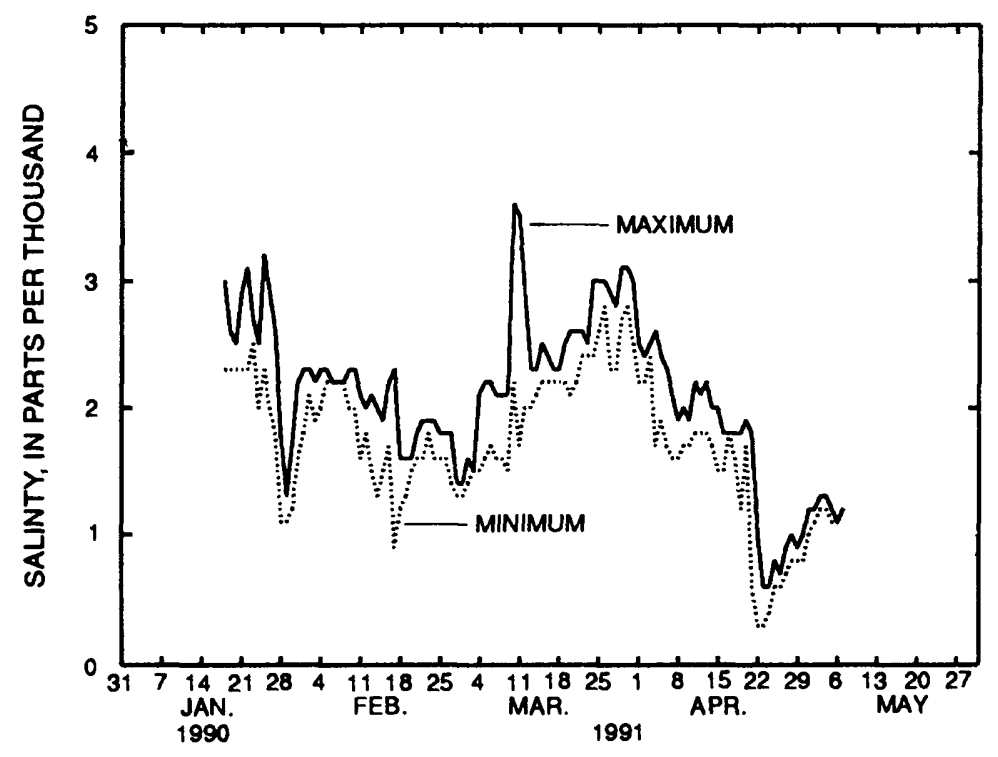


Table 43.--Daily mean values of specific conductance, near bottom, in water at site 4, Pasquotank River at light 1 , January through May 1991

STATION NUMBER AND NAME: 0204387900, Pasquotank River at light 1

LATITUDE: $36^{\circ} 09^{\prime} 06^{\prime \prime}$ LONGITUDE: $76^{\circ} 01^{\prime} 18^{\prime \prime}$ COUNTY: Camden PROBE LOCATION: 2 feet above bottom

[Specific conductance, microsiemens per centimeter at 25 degrees Celsius; ---, no data]

\begin{tabular}{|c|c|c|c|c|c|}
\hline Day & Jan. & Feb. & Mar. & Apr. & May \\
\hline 1 & --. & 4,650 & 3,140 & 4,660 & 2,390 \\
\hline 2 & --- & 4,710 & 3,150 & 4,620 & 2,420 \\
\hline 3 & --- & 4,620 & 3,180 & 4,820 & 2,560 \\
\hline 4 & --- & 4,730 & 3,300 & 4,640 & 2,610 \\
\hline 5 & --- & 4,630 & 4,950 & 4,560 & 2,370 \\
\hline 6 & --- & 4,620 & 3,840 & 4,240 & 2,330 \\
\hline 7 & --. & 4,640 & 3,780 & 3,820 & 2,450 \\
\hline 8 & -.- & 4,580 & 4,300 & 3,550 & --- \\
\hline 9 & --- & 4,640 & 4,650 & 3,500 & --- \\
\hline 10 & --- & 4,490 & 6,770 & 3,560 & --- \\
\hline 11 & --- & 4,380 & 4,510 & 3,860 & --- \\
\hline 12 & --- & 4,190 & 4,730 & 3,720 & --- \\
\hline 13 & --- & 4,230 & 4,320 & 4,000 & --- \\
\hline 14 & --- & 3,050 & 4,230 & 3,890 & --- \\
\hline 15 & --- & 3,170 & 4,540 & 3,830 & --- \\
\hline 16 & --- & 3,650 & 4,510 & 3,510 & --- \\
\hline 17 & --- & 3,520 & 4,460 & 3,620 & --. \\
\hline 18 & 5,090 & 3,850 & 4,470 & 3,460 & -.- \\
\hline 19 & 5,050 & 3,160 & 4,660 & 2,810 & --- \\
\hline 20 & 4,640 & 3,090 & 4,910 & 3,560 & --- \\
\hline 21 & 4,910 & 3,330 & 4,950 & 2,340 & --- \\
\hline 22 & 5,330 & 3,460 & 4,720 & 1,570 & --- \\
\hline 23 & 5,090 & 3,600 & 4,730 & 1,300 & -- \\
\hline 24 & 4,700 & 3,370 & 5,160 & 1,930 & -- \\
\hline 25 & 5,670 & 3,370 & 5,190 & 1,890 & --- \\
\hline 26 & 5,440 & 3,350 & 5,410 & 1,880 & --- \\
\hline 27 & 4,800 & 3,250 & 5,010 & 2,020 & --. \\
\hline 28 & 4,680 & 2,930 & 5,020 & 2,050 & --- \\
\hline 29 & 4,870 & $\cdots$ & 5,590 & 2,010 & --- \\
\hline 30 & 5,050 & $--\cdot$ & 5,550 & 2,140 & --- \\
\hline 31 & 4,480 & -- & 5,130 & --- & --- \\
\hline
\end{tabular}

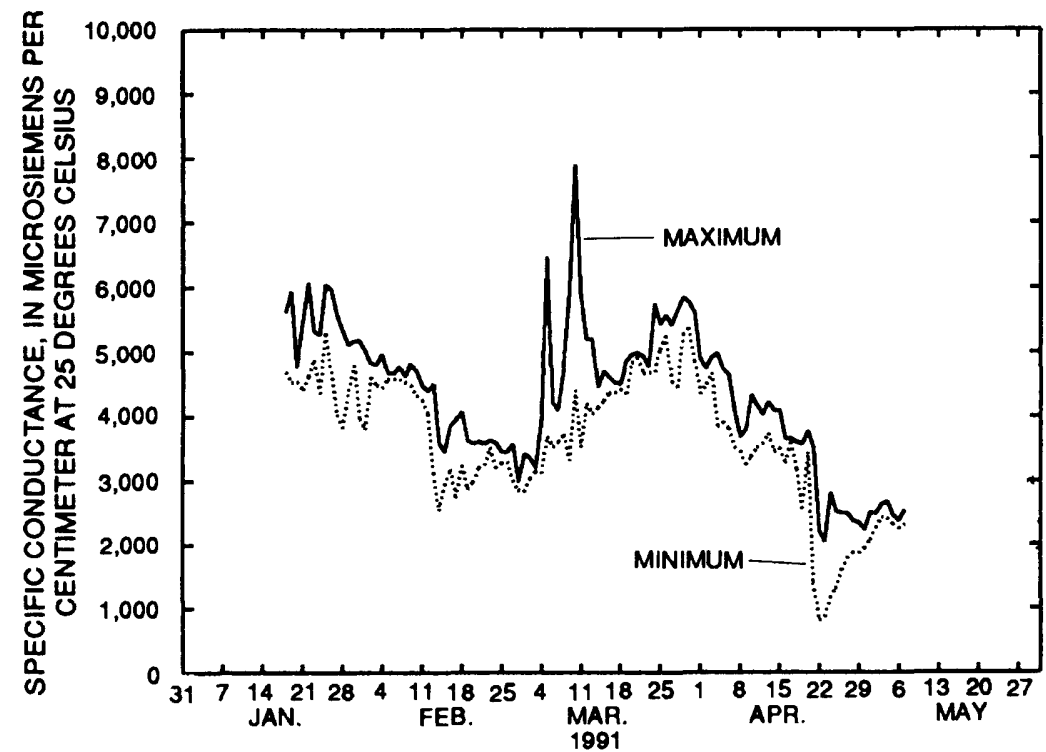


Table 44.--Daily mean values of salinity concentration, near bottom, in water at site 4, Pasquotank River at light 1 , January through May 1991

STATION NUMBER AND NAME: 0204387900, Pasquotank River at light 1

LATITUDE: $36^{\circ} 09^{\prime} 06^{\prime \prime}$ LONGITUDE: $76^{\circ} 01^{\prime} 18^{\prime \prime}$ COUNTY: Camden

PROBE LOCATION: 2 feet above bottom

[Salinity concentration, parts per thousand; ---, no data]

$\begin{array}{ccrrrr}\text { Day } & \text { Jan. } & \text { Feb. } & \text { Mar. } & \text { Apr. } & \text { May } \\ 1 & --- & 2.5 & 1.6 & 2.5 & 1.2 \\ 2 & --- & 2.5 & 1.6 & 2.4 & 1.2 \\ 3 & --- & 2.5 & 1.6 & 2.6 & 1.3 \\ 4 & --- & 2.5 & 1.7 & 2.5 & 1.3 \\ 5 & --- & 2.5 & 2.6 & 2.4 & 1.2\end{array}$

$\begin{array}{rrrrrr}6 & -- & 2.5 & 2.0 & 2.2 & 1.2 \\ 7 & -- & 2.5 & 2.0 & 2.0 & 1.2 \\ 8 & --- & 2.4 & 2.3 & 1.8 & -- \\ 9 & -- & 2.5 & 2.5 & 1.8 & \ldots \\ 10 & --- & 2.4 & 3.7 & 1.9 & --\end{array}$

$\begin{array}{llllll}11 & --- & 2.3 & 2.4 & 2.0 & -- \\ 12 & --- & 2.2 & 2.5 & 1.9 & -- \\ 13 & --- & 2.2 & 2.3 & 2.1 & -- \\ 14 & --- & 1.6 & 2.2 & 2.0 & -- \\ 15 & --- & 1.6 & 2.4 & 2.0 & --\end{array}$

$\begin{array}{llllll}16 & --- & 1.9 & 2.4 & 1.8 & -.- \\ 17 & --- & 1.8 & 2.4 & 1.9 & \ldots- \\ 18 & 2.7 & 2.0 & 2.4 & 1.8 & -- \\ 19 & 2.7 & 1.6 & 2.5 & 1.4 & \ldots \\ 20 & 2.5 & 1.6 & 2.6 & 1.9 & --\end{array}$

$\begin{array}{rrrrrr}21 & 2.6 & 1.7 & 2.6 & 1.2 & -- \\ 22 & 2.9 & 1.8 & 2.5 & .8 & -- \\ 23 & 2.7 & 1.9 & 2.5 & .6 & -- \\ 24 & \bullet 2.5 & 1.8 & 2.8 & 1.0 & -- \\ 25 & 3.1 & 1.7 & 2.8 & .9 & --\end{array}$

$\begin{array}{rrrrrr}26 & 2.9 & 1.7 & 2.9 & .9 & -- \\ 27 & 2.6 & 1.7 & 2.7 & 1.0 & -- \\ 28 & 2.5 & 1.5 & 2.7 & 1.0 & -- \\ 29 & 2.6 & -- & 3.0 & 1.0 & -- \\ 30 & 2.7 & -.- & 3.0 & 1.1 & \ldots- \\ 31 & 2.4 & --- & 2.7 & \ldots & --\end{array}$

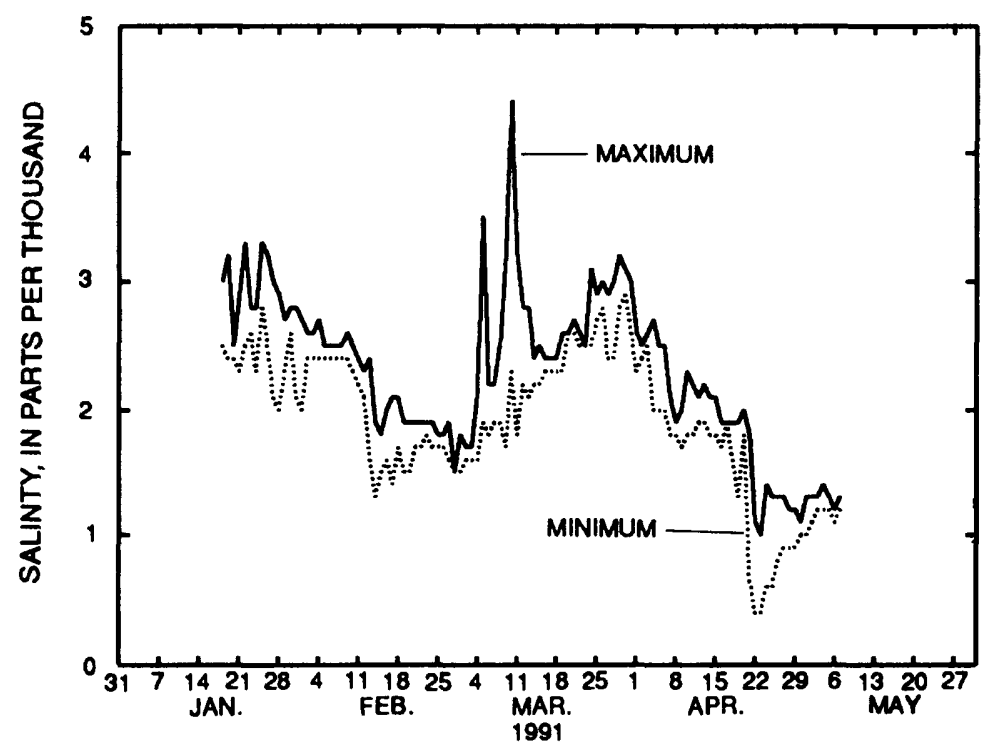


Table 45.--Daily mean values of water temperature, near surface, in water at site 4, Pasquotank River at light, January through May 1991

STATION NUMBER AND NAME: 0204387900, Pasquotank River at light 1

LATITUDE: $36^{\circ} 09^{\prime} 06^{\prime \prime}$ LONGITUDE: $76^{\circ} 01^{\prime} 18^{\prime \prime}$ COUNTY: Camden PROBE LOCATION: 8 feet above bottom

[Water temperature, degrees Celsius; ---, no data]

$\begin{array}{rrrrrr}\text { Day } & \text { Jan. } & \text { Feb. } & \text { Mar. } & \text { Apr. } & \text { May } \\ 1 & --- & 7.3 & 8.6 & 14.0 & 21.3 \\ 2 & --- & 7.3 & 9.2 & 14.4 & 21.4 \\ 3 & --- & 8.0 & 9.9 & 14.2 & 20.8 \\ 4 & --- & 7.9 & 10.5 & 14.4 & 20.4 \\ 5 & --- & 8.6 & 11.0 & 15.3 & 20.6 \\ & & & & & \\ 6 & --- & 9.4 & 10.5 & 16.0 & 21.7 \\ 7 & --- & 9.6 & 11.1 & 16.4 & 22.0 \\ 8 & --- & 9.4 & 10.8 & 16.6 & -- \\ 9 & --- & 9.2 & 10.7 & 17.8 & --- \\ 10 & --- & 8.8 & 10.3 & 18.4 & --\end{array}$

$\begin{array}{llllll}11 & -- & 8.4 & 9.6 & 17.9 & \ldots \\ 12 & -- & 7.8 & 9.0 & 17.1 & \ldots \\ 13 & -- & 7.6 & 9.1 & 16.5 & -\cdots \\ 14 & \cdots & 8.3 & 9.2 & 16.5 & \cdots \\ 15 & -- & 8.2 & 8.7 & 17.2 & \ldots\end{array}$

$\begin{array}{rrrrrr}16 & --- & 6.7 & 8.8 & 18.0 & \ldots- \\ 17 & --- & 5.5 & 9.3 & 18.8 & -- \\ 18 & 9.0 & 6.0 & 9.7 & 18.7 & -- \\ 19 & 8.6 & 6.5 & 10.1 & 17.6 & -- \\ 20 & 8.7 & 7.3 & 10.6 & 16.7 & --\end{array}$

$\begin{array}{llllll}21 & 8.8 & 8.3 & 10.9 & 15.9 & \ldots \\ 22 & 7.8 & 9.0 & 11.9 & 15.4 & \ldots \\ 23 & 7.0 & 8.1 & 12.7 & 15.7 & \ldots \\ 24 & 6.7 & 8.3 & 13.3 & 16.3 & -- \\ 25 & 6.9 & 8.3 & 13.7 & 16.8 & --\end{array}$

$\begin{array}{llllll}26 & 6.0 & 8.1 & 13.4 & 17.4 & -- \\ 27 & 6.3 & 7.7 & 14.4 & 17.8 & \ldots \\ 28 & 6.6 & 7.9 & 15.5 & 18.4 & -- \\ 29 & 7.0 & --- & 15.5 & 19.7 & -- \\ 30 & 7.4 & --- & 15.4 & 20.4 & -- \\ 31 & 7.5 & --- & 14.5 & -- & --\end{array}$

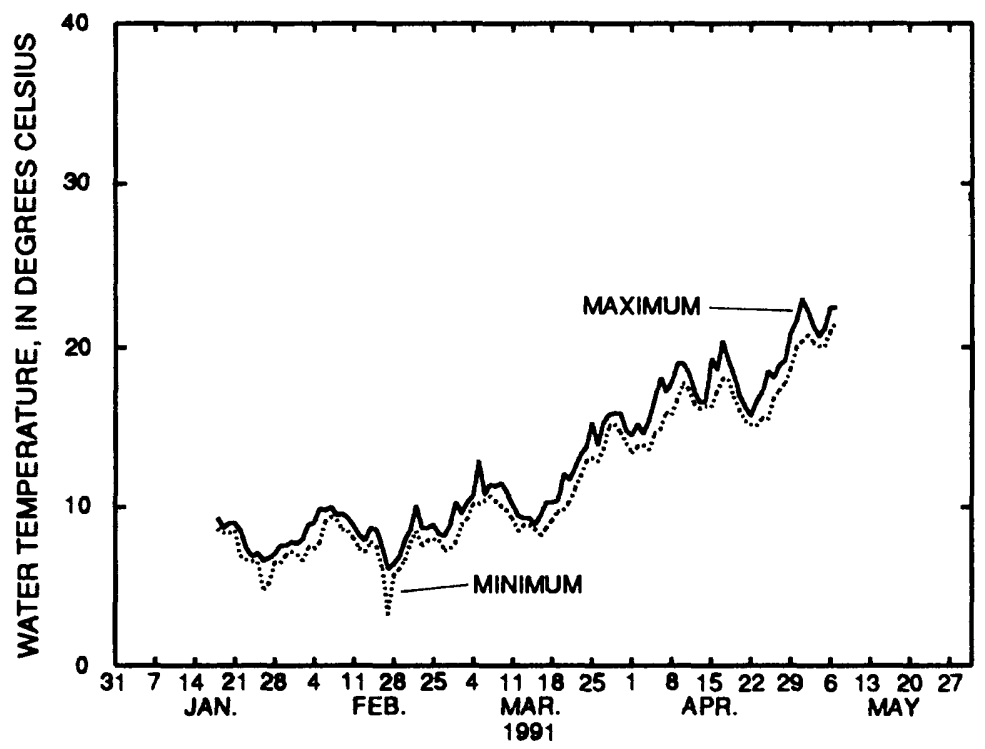


Table 46.--Daily mean values of dissolved-oxygen concentration, near surface, in water at site 4, Pasquotank River at light 1 , January through May 1991

STATION NUMBER AND NAME: 0204387900, Pasquotank River at light 1

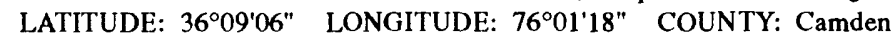
PROBE LOCATION: 8 feet above bottom

[Dissolved-oxygen concentration, milligrams per liter; ---, no data]

\begin{tabular}{|c|c|c|c|c|c|}
\hline Day & Jan. & Feb. & Mar. & Apr. & May \\
\hline 1 & -.- & 12.1 & 12.4 & 10.5 & 9.6 \\
\hline 2 & -.. & 12.2 & 11.8 & 10.9 & 9.3 \\
\hline 3 & $\cdots$ & 12.2 & 11.6 & 10.9 & 9.1 \\
\hline 4 & --- & 11.2 & 11.1 & 11.3 & 9.0 \\
\hline 5 & $\ldots$ & 11.2 & 11.4 & 11.3 & 8.8 \\
\hline 6 & --- & 12.5 & 10.9 & 11.2 & 8.7 \\
\hline 7 & ... & 12.8 & 10.8 & 11.2 & 8.8 \\
\hline 8 & --- & 12.0 & 10.7 & 11.0 & $\cdots$ \\
\hline 9 & --- & 11.8 & 11.0 & 10.5 & -.. \\
\hline 10 & --- & 11.8 & 11.0 & 10.1 & -- \\
\hline 11 & ... & 11.5 & 10.8 & 9.9 & -- \\
\hline 12 & -.. & 11.7 & 11.4 & 10.3 &.- \\
\hline 13 & --. & 11.8 & 11.4 & 10.5 & -- \\
\hline 14 & --- & 11.7 & 11.2 & 10.5 & -- \\
\hline 15 & --- & 11.7 & 11.3 & 10.5 & -- \\
\hline 16 & --- & 11.9 & 11.6 & 10.4 & -- \\
\hline 17 & -- & 12.4 & 11.8 & 10.4 & -- \\
\hline 18 & 11.2 & 12.7 & 11.5 & 10.0 & --- \\
\hline 19 & 11.5 & 12.6 & 11.0 & 9.9 & $\cdots$ \\
\hline 20 & 11.8 & 12.7 & 11.3 & 9.6 & $\cdots$ \\
\hline 21 & 11.4 & 13.0 & 11.4 & 9.7 & -- \\
\hline 22 & 11.5 & 12.9 & 11.3 & 9.9 & -. \\
\hline 23 & 11.7 & 12.1 & 11.2 & 10.1 & ... \\
\hline 24 & 11.6 & 11.9 & 10.6 & 10.0 & -- \\
\hline 25 & 11.2 & 12.1 & 10.5 & 10.2 & -- \\
\hline 26 & 12.0 & 11.8 & 10.6 & 10.2 & -- \\
\hline 27 & 12.1 & 11.7 & 10.7 & 10.3 & -.- \\
\hline 28 & 11.9 & 12.0 & 10.3 & 10.1 & -- \\
\hline 29 & 12.0 & -- & 10.2 & 10.2 & -- \\
\hline 30 & 12.3 & ... & 10.0 & 10.0 & -- \\
\hline 31 & 11.8 & $\cdots$ & 10.1 & --- & -- \\
\hline
\end{tabular}

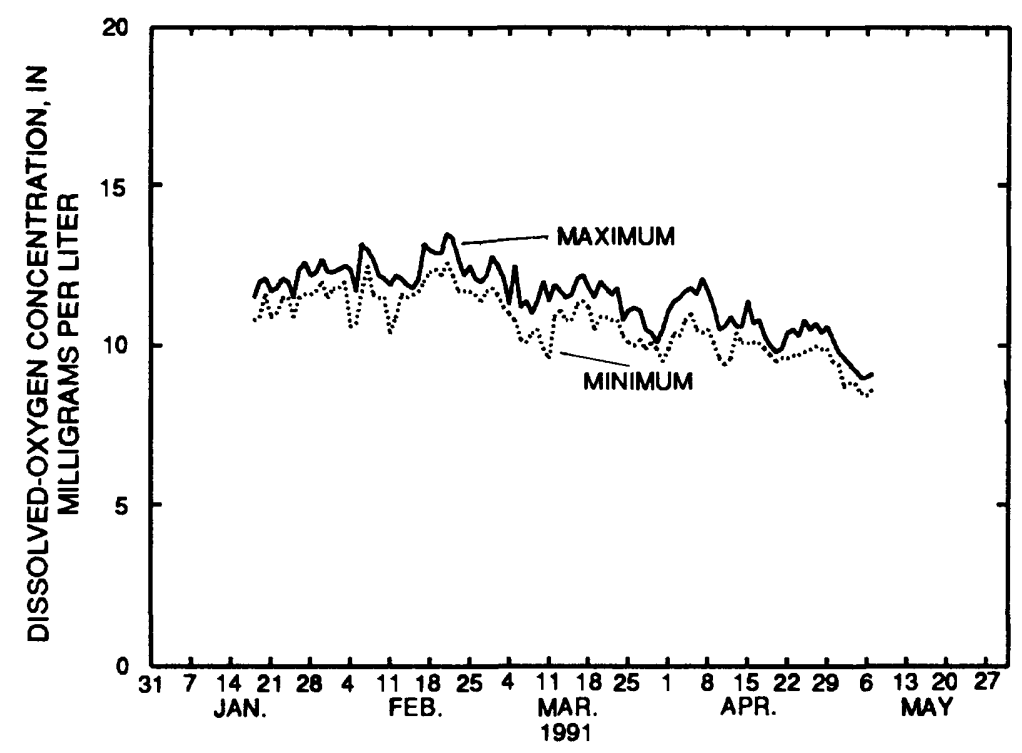


Table 47.--Daily mean values of dissolved-oxygen concentration, mid-depth, in water at site 4, Pasquotank River at light 1, January through May 1991

STATION NUMBER AND NAME: 0204387900, Pasquotank River at light 1

LATITUDE: $36^{\circ} 09^{\prime} 06^{\prime \prime}$ LONGITUDE: $76^{\circ} 01^{\prime} 18^{\prime \prime}$ COUNTY: Camden PROBE LOCATION: 6 feet above bottom

[Dissolved-oxygen concentration, milligrams per liter; ---, no data]

\begin{tabular}{|c|c|c|c|c|c|}
\hline Day & Jan. & Feb. & Mar. & Apr. & May \\
\hline 1 & --. & 9.8 & 11.0 & 9.8 & 10.5 \\
\hline 2 & ... & 9.9 & 10.7 & 10.1 & 9.7 \\
\hline 3 & $\cdots$ & 10.0 & 10.5 & 10.3 & 9.4 \\
\hline 4 & --- & 9.1 & 10.2 & 10.8 & 9.4 \\
\hline 5 & --- & 9.1 & 10.4 & 10.7 & 9.3 \\
\hline 6 & --- & 10.3 & 10.1 & 10.6 & 8.9 \\
\hline 7 & --- & 10.6 & 10.1 & 10.5 & 8.7 \\
\hline 8 & --- & 10.0 & 9.9 & 10.5 & --- \\
\hline 9 & --- & 9.7 & 10.2 & 10.1 & --. \\
\hline 10 & --. & 9.7 & 10.3 & 9.7 & --. \\
\hline 11 & --. & 9.4 & 10.2 & 9.3 & --- \\
\hline 12 & $\ldots$ & 9.8 & 10.7 & 9.9 & ...- \\
\hline 13 & --. & 10.0 & 10.8 & 10.1 & --- \\
\hline 14 & $\ldots$ & 9.9 & 10.7 & 10.0 & $-\cdots$ \\
\hline 15 & --. & 10.0 & 10.8 & 10.1 & -- \\
\hline 16 & --. & 10.3 & 11.1 & 10.1 & $\ldots$ \\
\hline 17 & $\ldots$ & 10.7 & 11.4 & 10.0 & -- \\
\hline 18 & 9.3 & 10.8 & 11.1 & 9.8 & --. \\
\hline 19 & 9.3 & 11.0 & 10.6 & 9.9 & -- \\
\hline 20 & 9.6 & 11.0 & 10.9 & 10.0 & -.. \\
\hline 21 & 9.3 & 11.2 & 11.0 & 10.1 & --. \\
\hline 22 & 9.4 & 11.2 & 10.9 & 10.3 & --- \\
\hline 23 & 9.6 & 10.7 & 11.0 & 10.5 & --. \\
\hline 24 & 9.4 & 10.4 & 10.6 & 10.3 & -- \\
\hline 25 & 9.0 & 10.6 & 10.3 & 10.6 & $\ldots$ \\
\hline 26 & 9.7 & 10.5 & 10.5 & 10.9 & -.. \\
\hline 27 & 9.9 & 10.5 & 10.3 & 10.8 & --- \\
\hline 28 & 9.6 & 10.7 & 9.7 & 10.8 & $\ldots$ \\
\hline 29 & 9.3 & --. & 9.7 & 10.9 & $\cdots$ \\
\hline 30 & 9.1 & -.. & 9.3 & 10.1 & ... \\
\hline 31 & 9.6 & --- & 9.4 & --. & -- \\
\hline
\end{tabular}

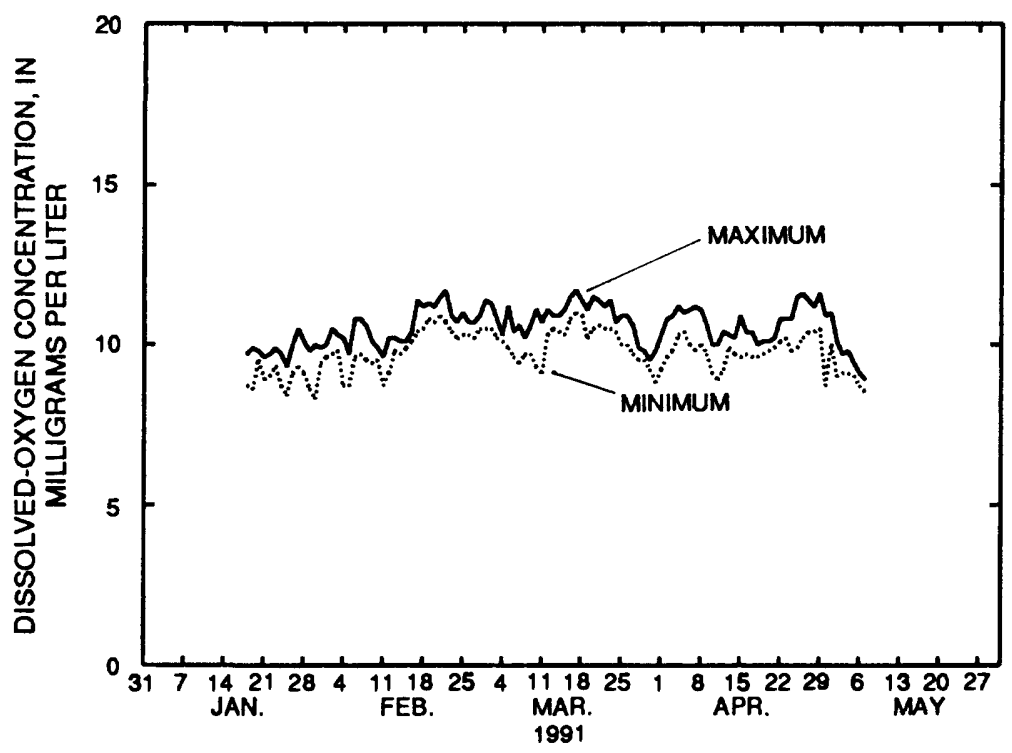


Table 48.--Daily mean values of dissolved-oxygen concentration, near bottom, in water at site 4, Pasquotank River at light 1, January through May 1991

STATION NUMBER AND NAME: 0204387900, Pasquotank River at light 1

LATITUDE: $36^{\circ} 09^{\prime} 06^{\prime \prime}$ LONGITUDE: $76^{\circ} 01^{\prime} 18^{\prime \prime}$ COUNTY: Camden PROBE LOCATION: 2 feet above bottom

[Dissolved-oxygen concentration, milligrams per liter; ---, no data]

\begin{tabular}{|c|c|c|c|c|c|}
\hline Day & Jan. & Feb. & Mar. & Apr. & May \\
\hline 1 & ... & 11.7 & 11.0 & 9.7 & 8.5 \\
\hline 2 & --. & 11.8 & 11.3 & 9.9 & 9.0 \\
\hline 3 & --- & 11.5 & 11.2 & 10.3 & 8.8 \\
\hline 4 & -- & 10.4 & 10.9 & 10.4 & 8.8 \\
\hline 5 & --- & 10.6 & 10.1 & 10.3 & 8.9 \\
\hline 6 & $\ldots$ & 11.1 & 10.7 & 9.6 & 8.6 \\
\hline 7 & --- & 10.7 & 10.7 & 9.5 & 8.6 \\
\hline 8 & -- & 11.5 & 9.8 & 10.2 & -.. \\
\hline 9 & --- & 11.3 & 8.7 & 9.9 & --- \\
\hline 10 & -- & 11.3 & 7.3 & 9.4 & --- \\
\hline 11 & $\ldots$ & 10.8 & 10.7 & 9.2 & --- \\
\hline 12 & -.. & 11.3 & 11.1 & 9.7 & --- \\
\hline 13 & --- & 11.5 & 11.0 & 9.9 & --. \\
\hline 14 & -.- & 11.4 & 11.1 & 9.8 & -.. \\
\hline 15 & -- & 11.4 & 11.2 & 9.6 & --- \\
\hline 16 & $\ldots$ & 11.6 & 11.5 & 9.8 & -.- \\
\hline 17 & -.- & 12.1 & 11.6 & 9.7 & --- \\
\hline 18 & 11.1 & 11.7 & 11.4 & 9.5 & -- \\
\hline 19 & 11.1 & 11.6 & 10.9 & 9.7 & ... \\
\hline 20 & 11.5 & 12.2 & 11.1 & 9.7 & $\cdots$ \\
\hline 21 & 11.3 & 12.1 & 11.2 & 9.7 & -- \\
\hline 22 & 11.5 & 12.0 & 11.0 & 9.9 & $\cdots$ \\
\hline 23 & 11.7 & 11.7 & 11.1 & 9.9 & --- \\
\hline 24 & 11.2 & 11.4 & 10.7 & 9.4 & $\cdots$ \\
\hline 25 & 11.0 & 11.6 & 10.3 & 9.6 & --- \\
\hline 26 & 11.0 & 11.4 & 10.4 & 9.3 & -- \\
\hline 27 & 11.8 & 11.4 & 10.1 & 9.0 & --- \\
\hline 28 & 10.9 & 11.6 & 9.4 & 9.1 & -.. \\
\hline 29 & 10.7 & --- & 9.3 & 9.1 & -.. \\
\hline 30 & 10.7 & --- & 9.4 & 7.9 & --- \\
\hline 31 & 11.2 & --- & 9.4 & -- & --- \\
\hline
\end{tabular}

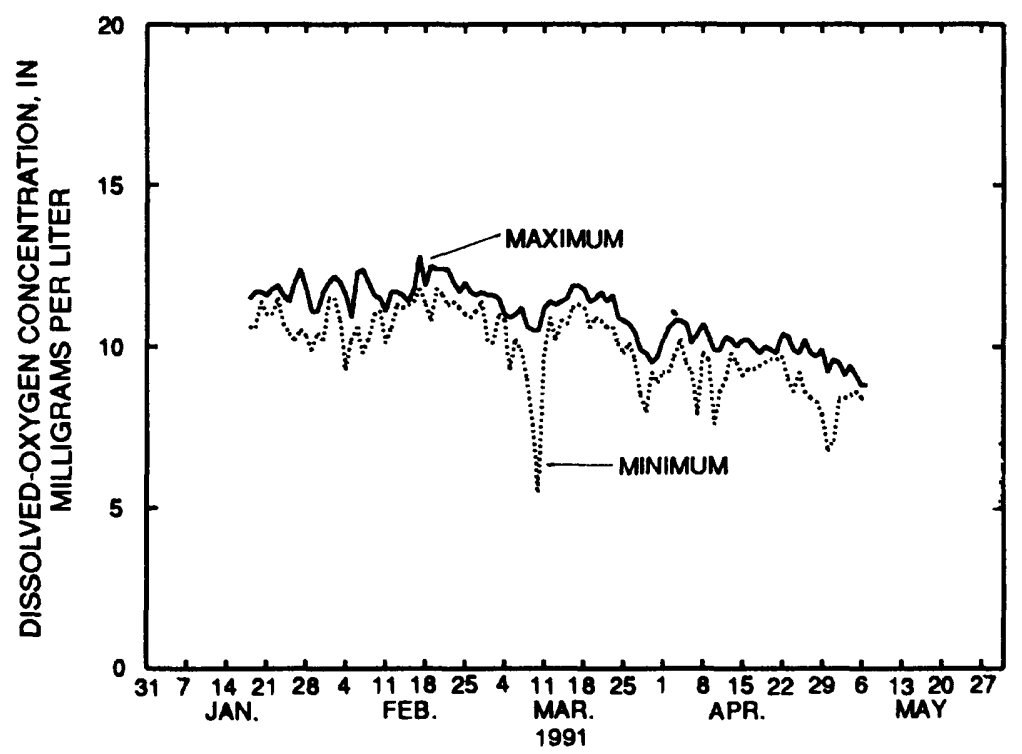


Table 49.--Daily mean values of specific conductance, near surface, in water at site 5, Currituck Sound at U.S. Highway 158 bridge, January through September 1990

STATION NUMBER AND NAME: 0204295500, Currituck Sound at U.S. Highway 158 bridge LATITUDE: $36^{\circ} 05^{\prime} 12^{\prime \prime}$ LONGITUDE: $75^{\circ} 46^{\prime} 06^{\prime \prime}$ COUNTY: Currituck PROBE LOCATION: 7 feet above bottom

[Specific conductance, microsiemens per centimeter at 25 degrees Celsius; ---, no data]

\begin{tabular}{|c|c|c|c|c|c|c|c|c|c|}
\hline Day & Jan. & Feb. & Mar. & Apr. & May & June & July & Aug. & Sept. \\
\hline 1 & -.- & 2,370 & --- & 1,970 & 1,350 & 2,740 & 2,840 & 2,230 & 3,190 \\
\hline 2 & --- & 2,410 & 2,130 & 2,830 & 1,450 & --- & 1,700 & 2,680 & 3,890 \\
\hline 3 & --- & 2,410 & 2,110 & 3,040 & 1,550 & --- & 1,400 & 3,980 & 4,680 \\
\hline 4 & --- & 2,440 & 2,090 & 2,740 & 1,410 & -- & 2,520 & 3,980 & 3,700 \\
\hline 5 & --. & --- & 2,130 & 2,860 & 1,960 & 2,460 & 3,680 & 4,410 & --- \\
\hline 6 & -.. & 2,370 & -.. & 2,880 & 1,820 & 1,950 & 1,860 & 7,650 & 4,620 \\
\hline 7 & --- & 2,400 & --- & 2,250 & 1,470 & 3,180 & 1,340 & 6,520 & 5,560 \\
\hline 8 & --- & 2,300 & --- & 2,010 & 1,410 & 2,390 & 1,910 & 4,460 & --- \\
\hline 9 & -.. & 2,390 & -.. & 2,070 & 1,440 & 3,250 & 4,400 & 4,970 & 4,240 \\
\hline 10 & --- & 2,830 & 2,120 & 2,460 & 2,710 & 2,910 & --- & 5,190 & 7,510 \\
\hline 11 & --- & $\ldots$ & 2,170 & 2,870 & 2,560 & 1,970 & --- & 5,110 & 6,740 \\
\hline 12 & $-\cdots-$ & 2,300 & 2,150 & 2,110 & 1,380 & 1,690 & 5,180 & 5,470 & 5,630 \\
\hline 13 & 2,500 & 2,340 & 2,190 & 1,960 & 1,990 & 1,740 & 6,250 & 5,900 & 6,610 \\
\hline 14 & 2,160 & 2,410 & 2,190 & 1,940 & 1,800 & 1,760 & 5,410 & 5,770 & 7,570 \\
\hline 15 & 2,640 & 2,360 & 2,190 & 2,170 & 1,440 & 2,390 & 9,030 & 4,870 & 7,720 \\
\hline 16 & 2,410 & 2,400 & 2,520 & 1,970 & 1,440 & 2,050 & --- & 4,660 & 6,830 \\
\hline 17 & 2,380 & --. & 3,960 & 1,980 & 1,890 & 2,100 & 4,180 & 4,500 & 5,950 \\
\hline 18 & 2,630 & --- & 3,630 & 1,940 & 1,760 & 1,790 & 3,680 & 4,480 & 4,110 \\
\hline 19 & --- & -.- & 2,580 & 1,760 & 1,570 & 2,760 & 3,380 & 4,740 & 6,100 \\
\hline 20 & 2,040 & -.- & 2,250 & 1,780 & -- & 2,360 & 3,850 & 4,640 & 7,990 \\
\hline 21 & 2,510 & --- & 2,130 & 2,240 & --- & 3,130 & 4,640 & 4,080 & 5,250 \\
\hline 22 & 2,400 & --. & 2,180 & 1,940 & 1,510 & 2,880 & 4,650 & 4,000 & 8,160 \\
\hline 23 & 2,360 & --- & 2,290 & 1,650 & 1,480 & 5,750 & 4,600 & 4,760 & 6,840 \\
\hline 24 & 2,430 & --- & 2,150 & 1,400 & 1,250 & 5,880 & 4,130 & 5,980 & 4,280 \\
\hline 25 & 2,610 & --- & 2,060 & 1,420 & 1,600 & 2,390 & 3,360 & 5,760 & 5,630 \\
\hline 26 & 2,660 & --- & 2,150 & 1,410 & 1,940 & 2,320 & 2,550 & 6,050 & 7,900 \\
\hline 27 & 2,490 & --- & 2,110 & 1,370 & 2,720 & 2,460 & 2,890 & 4,780 & 6,240 \\
\hline 28 & 2,440 & 2,080 & 2,110 & 1,370 & 1.560 & 2,890 & 4,360 & 4,490 & 4,720 \\
\hline 29 & 2,270 & --- & $\cdots$ & 1,460 & 3,320 & 3,820 & 4,160 & 4,770 & 5,110 \\
\hline 30 & 2,400 & --- & 2,160 & 1,410 & 1,910 & 4,640 & 3,780 & 4,450 & 6,530 \\
\hline 31 & 2,260 & --- & 1,990 & -.. & 1,590 & -.- & 2,110 & 3,200 & -- \\
\hline
\end{tabular}

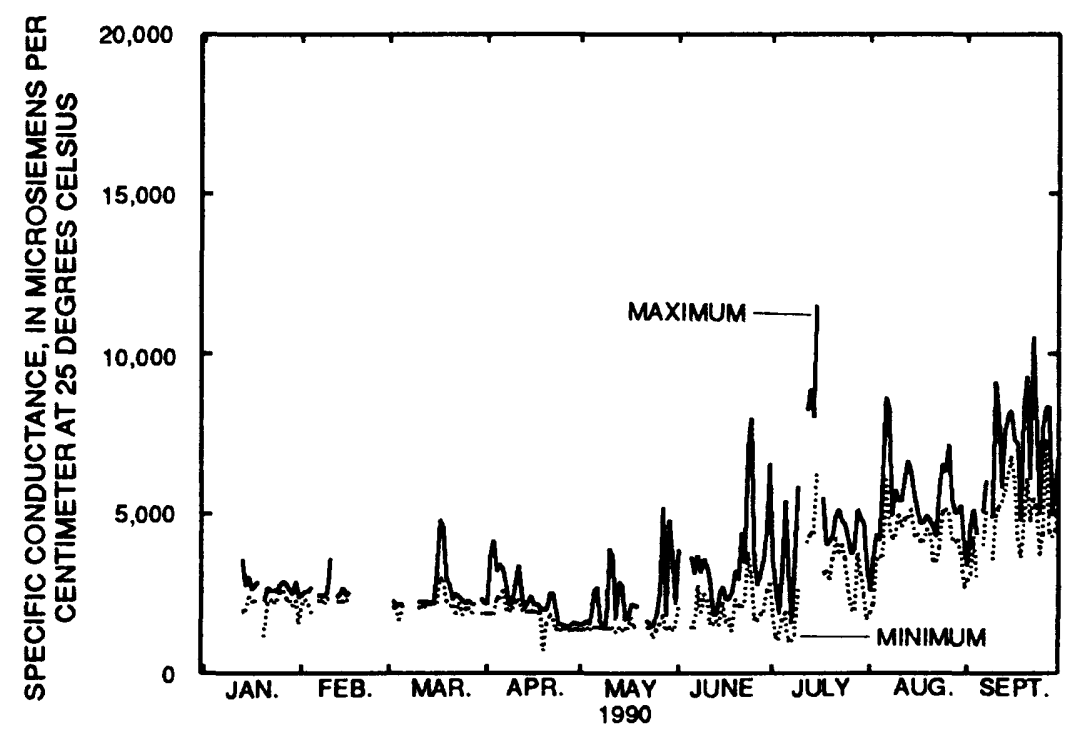


Table 50.--Daily mean values of specific conductance, near surface, in water at site 5, Currituck Sound at U.S. Highway 158 bridge, October 1990 through April 1991

STATION NUMBER AND NAME: 0204295500, Currituck Sound at U.S. Highway 158 bridge LATITUDE: $36^{\circ} 05^{\prime} 12^{\prime \prime}$ LONGITUDE: $75^{\circ} 46^{\prime} 06^{\prime \prime}$ COUNTY: Currituck PROBE LOCATION: 7 feet above bottom

[Specific conductance, microsiemens per centimeter at 25 degrees Celsius; ---, no data]

\begin{tabular}{|c|c|c|c|c|c|c|c|}
\hline Day & Oct. & Nov. & Dec. & Jan. & Feb. & Mar. & Apr. \\
\hline 1 & 5,410 & 7,470 & 5,970 & 4,970 & 2,940 & 2,830 & 4,540 \\
\hline 2 & 6,000 & 7,030 & 6,030 & 4,680 & 3,070 & 4,610 & 4,420 \\
\hline 3 & 6,040 & 7,110 & 6,260 & 4,620 & 3,130 & 4,850 & -- \\
\hline 4 & 7,050 & 7,250 & 8,310 & 4,700 & 2,800 & 6,910 & -.- \\
\hline 5 & 6,600 & 7,580 & 6,660 & 4,120 & 2,640 & 5,700 & --- \\
\hline 6 & 6,050 & 7,860 & 6,510 & 4,700 & 2,550 & 6,600 & --- \\
\hline 7 & 6,910 & 7,560 & 6,490 & 4,910 & 2,580 & 7,210 & -.- \\
\hline 8 & 7,330 & 7,430 & 5,500 & 3,380 & 2,410 & 3,960 & -.. \\
\hline 9 & 7,070 & 7,250 & 4,630 & 3,270 & 2,280 & 3,070 & --. \\
\hline 10 & 8,310 & 8,620 & 5,620 & 3,340 & 2,320 & 2,940 & --. \\
\hline 11 & 12,400 & 7,870 & 5,620 & 3,900 & 2,660 & 2,610 & -.- \\
\hline 12 & 11,100 & 8,050 & 6,130 & 5,000 & 2,370 & 2,350 & -.. \\
\hline 13 & 10,200 & 6,600 & 6,060 & 3,970 & 2,850 & 3,320 & -- \\
\hline 14 & 11,200 & -.. & 5,320 & 4,220 & 4,400 & 3,970 & -.. \\
\hline 15 & 11,600 & 6,590 & 6,220 & 6,050 & 3,760 & 2,930 & -.- \\
\hline 16 & 8,820 & 7,090 & 6,590 & 5,900 & 2,330 & 2,370 & -.. \\
\hline 17 & 9.160 & 6,840 & 5,920 & 5,890 & 2,460 & 3,470 & -.- \\
\hline 18 & 13,100 & 4,520 & 6,600 & 5,060 & 2,400 & 4,820 & --- \\
\hline 19 & 12,100 & 5,140 & 6,510 & 3,860 & 2,750 & 4,490 & -.. \\
\hline 20 & 8,220 & 5,910 & 5,080 & 3,460 & 3,200 & 4,200 & --- \\
\hline 21 & 7,590 & 6,030 & 6,000 & 3,640 & 2,510 & 4,340 & --- \\
\hline 22 & 8,740 & 6,670 & 6,700 & 2,450 & 2,420 & 5,080 & $\ldots$ \\
\hline 23 & 11,000 & 7,090 & 7,600 & 2,890 & 2,160 & 4,490 & --- \\
\hline 24 & 10,200 & 7,100 & 9,870 & 3,290 & 2,160 & 4,580 & -- \\
\hline 25 & 8,620 & 7,050 & 5,570 & 2,770 & 2,170 & 3,050 & $\cdots$ \\
\hline 26 & 4,370 & 6,360 & 5,050 & 2,790 & 2,210 & -.. & --- \\
\hline 27 & 3,740 & 5,920 & 4,310 & 3,450 & 2,460 & --- & -- \\
\hline 28 & 7,250 & 6,600 & 4,390 & 3,630 & 2,780 & 7,610 & -- \\
\hline 29 & 7,240 & 6,700 & 5,310 & 3,580 & --- & 7,430 & -- \\
\hline 30 & 6,860 & 5,270 & 6,850 & 3,610 &..- & 6,700 & -- \\
\hline 31 & 7,660 & $\cdots$ & 6,930 & 3,610 & --- & 4,930 & --- \\
\hline
\end{tabular}

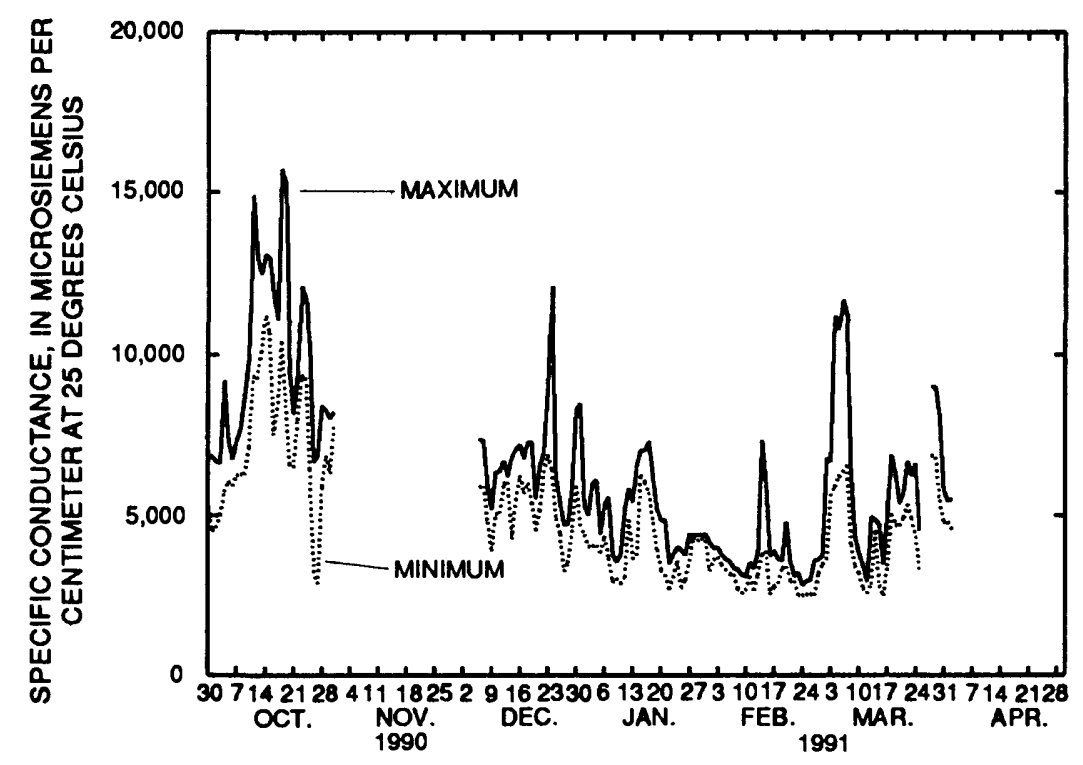


Table 51.--Daily mean values of salinity concentration, near surface, in water at site 5, Currituck Sound at U.S. Highway 158 bridge, January through September 1990

STATION NUMBER AND NAME: 0204295500, Currituck Sound at U.S. Highway 158 bridge LATITUDE: $36^{\circ} 05^{\prime} 12^{\prime \prime}$ LONGITUDE: $75^{\circ} 46^{\prime} 06^{\prime \prime}$ COUNTY: Currituck

PROBE LOCATION: 7 feet above bottom

[Salinity concentration, parts per thousand; ---, no data]

\begin{tabular}{|c|c|c|c|c|c|c|c|c|c|}
\hline Day & Jan. & Feb. & Mar. & Apr. & May & June & July & Aug. & Sept. \\
\hline 1 & -. & 1.2 & --- & 1.0 & 0.7 & 1.4 & 1.5 & 1.1 & 1.6 \\
\hline 2 & --- & 1.2 & 1.1 & 1.5 & .7 & --- & .8 & 1.4 & 2.0 \\
\hline 3 & --. & 1.2 & 1.1 & 1.6 & .8 & --- & .7 & 2.1 & 2.5 \\
\hline 4 & ... & 1.2 & 1.0 & 1.4 & .7 & --- & 1.3 & 2.1 & 1.9 \\
\hline 5 & --- & -. & 1.1 & 1.5 & 1.0 & 1.3 & 1.9 & 2.3 & --- \\
\hline 6 & --- & 1.2 & --- & 1.5 & .9 & 1.0 & .9 & 4.2 & 2.5 \\
\hline 7 & -.. & 1.2 & --- & 1.1 & .7 & 1.6 & .7 & 3.6 & 3.0 \\
\hline 8 & --- & 1.2 & -- & 1.0 & .7 & 1.2 & 1.0 & 2.4 & --- \\
\hline 9 & --- & 1.2 & -- & 1.0 & .7 & 1.7 & 2.3 & 2.7 & 2.2 \\
\hline 10 & -- & 1.5 & 1.1 & 1.2 & 1.4 & 1.5 & --- & 2.8 & 4.1 \\
\hline 11 & $\ldots$ & -- & 1.1 & 1.5 & 1.3 & 1.0 & -.. & 2.7 & 3.7 \\
\hline 12 & $\cdots$ & 1.2 & 1.1 & 1.1 & .7 & .8 & 2.8 & 2.9 & 3.0 \\
\hline 13 & 1.3 & 1.2 & 1.1 & 1.0 & 1.0 & .9 & 3.4 & 3.2 & 3.6 \\
\hline 14 & 1.1 & 1.2 & 1.1 & 1.0 & .9 & .9 & 2.9 & 3.1 & 4.2 \\
\hline 15 & 1.3 & 1.2 & 1.1 & 1.1 & .7 & 1.2 & 5.0 & 2.6 & 4.3 \\
\hline 16 & 1.2 & 1.2 & 1.3 & 1.0 & .7 & 1.0 & ... & 2.5 & 3.7 \\
\hline 17 & 1.2 & --- & 2.1 & 1.0 & .9 & 1.1 & 2.2 & 2.4 & 3.2 \\
\hline 18 & 1.3 & -.. & 1.9 & 1.0 & .9 & .9 & 1.9 & 2.4 & 2.2 \\
\hline 19 & --- & ..- & 1.3 & .9 & .8 & 1.4 & 1.8 & 2.5 & 3.3 \\
\hline 20 & 1.0 & --- & 1.1 & .9 & --- & 1.2 & 2.0 & 2.5 & 4.4 \\
\hline 21 & 1.3 & -.. & 1.1 & 1.1 & ... & 1.6 & 2.5 & 2.1 & 2.8 \\
\hline 22 & 1.2 & --- & 1.1 & 1.0 & .7 & 1.5 & 2.5 & 2.1 & 4.5 \\
\hline 23 & 1.2 & -- & 1.2 & .8 & .7 & 3.1 & 2.4 & 2.5 & 3.7 \\
\hline 24 & 1.2 & ... & 1.1 & .7 & .6 & 3.2 & 2.2 & 3.2 & 2.3 \\
\hline 25 & 1.3 & -- & 1.0 & .7 & .8 & 1.2 & 1.7 & 3.1 & 3.0 \\
\hline 26 & 1.4 & --. & 1.1 & .7 & 1.0 & 1.2 & 1.3 & 3.3 & 4.4 \\
\hline 27 & 1.3 & -- & 1.1 & .7 & 1.4 & 1.2 & 1.5 & 2.5 & 3.4 \\
\hline 28 & 1.2 & 1.0 & 1.1 & .7 & .8 & 1.5 & 2.3 & 2.4 & 2.5 \\
\hline 29 & 1.1 & -- & -.. & .7 & 1.7 & 2.0 & 2.2 & 2.5 & 2.7 \\
\hline 30 & 1.2 & -.- & 1.1 & .7 & 1.0 & 2.5 & 2.0 & 2.4 & 3.6 \\
\hline 31 & 1.1 & --. & 1.0 & --. & .8 & --- & 1.1 & 1.7 & -.. \\
\hline
\end{tabular}

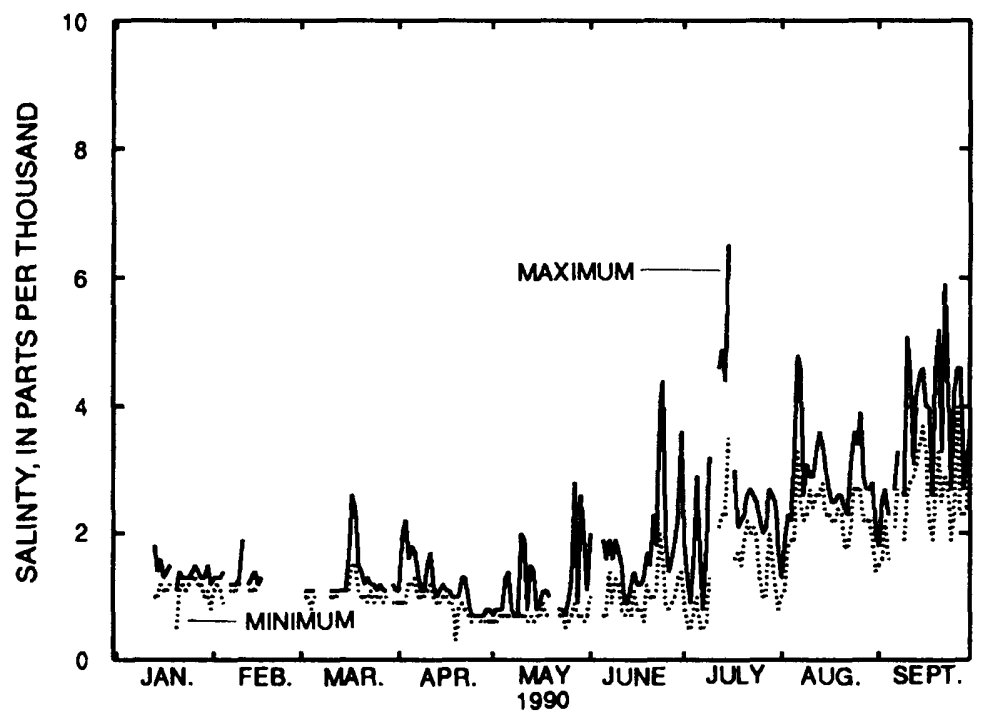


Table 52.--Daily mean values of salinity concentration, near surface, in water at site 5, Currituck Sound at U.S. Highway 158 bridge, October 1990 through April 1991

STATION NUMBER AND NAME: 0204295500, Currituck Sound at U.S. Highway 158 bridge LATITUDE: $36^{\circ} 05^{\prime} 12^{\prime \prime}$ LONGITUDE: $75^{\circ} 46^{\prime} 06^{\prime \prime}$ COUNTY: Currituck

PROBE LOCATION: 7 feet above bottom

[Salinity concentration, parts per thousand; --., no data]

\begin{tabular}{|c|c|c|c|c|c|c|c|}
\hline Day & Oct. & Nov. & Dec. & Jan. & Feb. & Mar. & Apr. \\
\hline 1 & 2.9 & 4.1 & 3.2 & 2.6 & 1.5 & 1.5 & 2.4 \\
\hline 2 & 3.2 & 3.8 & 3.3 & 2.5 & 1.6 & 2.4 & 2.3 \\
\hline 3 & 3.3 & 3.9 & 3.4 & 2.4 & 1.6 & 2.6 & -.- \\
\hline 4 & 3.9 & 4.0 & 4.6 & 2.5 & 1.4 & 3.8 & ... \\
\hline 5 & 3.6 & 4.2 & 3.6 & 2.2 & 1.3 & 3.1 & -.. \\
\hline 6 & 3.3 & 4.3 & 3.5 & 2.5 & 1.3 & 3.6 & $\ldots$ \\
\hline 7 & 3.8 & 4.2 & 3.5 & 2.6 & 1.3 & 4.0 & --- \\
\hline 8 & 4.0 & 4.1 & 3.0 & 1.8 & 1.2 & 2.1 & -- \\
\hline 9 & 3.9 & 4.0 & 2.5 & 1.7 & 1.2 & 1.6 & -.. \\
\hline 10 & 4.6 & 4.8 & 3.0 & 1.7 & 1.2 & 1.5 & --. \\
\hline 11 & 7.1 & 4.3 & 3.0 & 2.0 & 1.4 & 1.3 & -.. \\
\hline 12 & 6.3 & 4.5 & 3.3 & 2.7 & 1.2 & 1.2 & -.. \\
\hline 13 & 5.8 & 3.6 & 3.3 & 2.1 & 1.5 & 1.7 & ... \\
\hline 14 & 6.4 & $\ldots$ & 2.9 & 2.2 & 2.3 & 2.1 & --- \\
\hline 15 & 6.6 & 3.6 & 3.4 & 3.3 & 2.0 & 1.5 & $\ldots$ \\
\hline 16 & 4.9 & 3.9 & 3.6 & 3.2 & 1.2 & 1.2 & -- \\
\hline 17 & 5.1 & 3.7 & 3.2 & 3.2 & 1.2 & 1.8 & -.- \\
\hline 18 & 7.5 & 2.4 & 3.6 & 2.7 & 1.2 & 2.6 & -.- \\
\hline 19 & 6.9 & 2.8 & 3.5 & 2.0 & 1.4 & 2.4 & ..- \\
\hline 20 & 4.5 & 3.2 & 2.7 & 1.8 & 1.7 & 2.2 & --- \\
\hline 21 & 4.2 & 3.3 & 3.2 & 1.9 & 1.3 & 2.3 & ... \\
\hline 22 & 4.9 & 3.6 & 3.7 & 1.2 & 1.2 & 2.7 & --- \\
\hline 23 & 6.2 & 3.9 & 4.2 & 1.5 & 1.1 & 2.4 & $\cdots$ \\
\hline 24 & 5.7 & 3.9 & 5.5 & 1.7 & 1.1 & 2.4 & $\ldots$ \\
\hline 25 & 4.8 & 3.9 & 3.0 & 1.4 & 1.1 & 1.6 & -.. \\
\hline 26 & 2.3 & 3.5 & 2.7 & 1.4 & 1.1 & --. & -- \\
\hline 27 & 2.0 & 3.2 & 2.3 & 1.8 & 1.3 & --- & $\ldots$ \\
\hline 28 & 4.0 & 3.6 & 2.3 & 1.9 & 1.4 & 4.2 & $\ldots$ \\
\hline 29 & 4.0 & 3.7 & 2.8 & 1.9 & --- & 4.1 & --. \\
\hline 30 & 3.7 & 2.8 & 3.7 & 1.9 & --. & 3.7 & ... \\
\hline 31 & 4.2 & --- & 3.8 & 1.9 & --- & 2.6 & 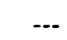 \\
\hline
\end{tabular}

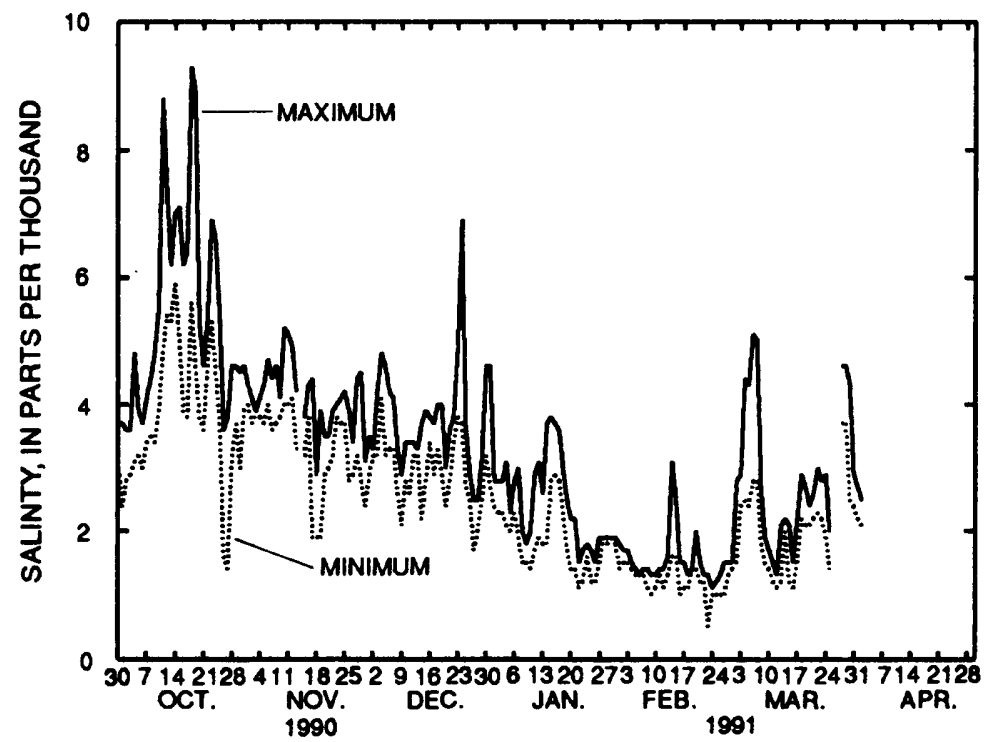


Table 53.--Daily mean values of specific conductance, near bottom, in water at site 5, Currituck Sound at U.S. Highway 158 bridge, January through September 1990

STATION NUMBER AND NAME: 0204295500, Currituck Sound at U.S. Highway 158 bridge LATITUDE: $36^{\circ} 05^{\prime} 12^{\prime \prime}$ LONGITUDE: $75^{\circ} 46^{\prime} 06^{\prime \prime}$ COUNTY: Currituck

PROBE LOCATION: 2 feet above bottom

[Specific conductance, microsiemens per centimeter at 25 degrees Celsius; -.-., no data]

\begin{tabular}{|c|c|c|c|c|c|c|c|c|c|}
\hline Day & Jan. & Feb. & Mar. & Apr. & May & June & July & Aug. & Sept. \\
\hline 1 & --- & 2,390 & $\ldots$ & 1,980 & 1,360 & --- & 3,120 & 2,080 & 3,930 \\
\hline 2 & --- & 2,430 & 2,290 & 3,170 & 1,450 & -.. & 1,710 & 5,260 & 4,580 \\
\hline 3 & --- & 2,450 & 2,440 & 3,110 & 1,550 & -.. & 1,340 & 5,900 & 5,420 \\
\hline 4 & -.. & 2,470 & 2,430 & 2,810 & 1,400 & $\ldots$ & 2,720 & 5,760 & 4,480 \\
\hline 5 & --- & $\cdots$ & 2,510 & 2,900 & 1,980 & --- & 4,390 & 4,660 & --- \\
\hline 6 & --. & 2,380 & 2,670 & 2,880 & 1,840 & 2,560 & 2,040 & 7,340 & 4,670 \\
\hline 7 & -.. & 2,410 & 2,560 & 2,250 & 1,450 & 3,480 & 1,160 & 7,120 & 5,780 \\
\hline 8 & ... & 2,350 & 2,540 & 2,010 & 1,410 & 2,550 & 1,740 & 5,490 & --- \\
\hline 9 & --. & 2,410 & 2,760 & 2,070 & 1,460 & 3,540 & 4,680 & 5,440 & 4,650 \\
\hline 10 & --- & 2,850 & 2,210 & 2,450 & 2,830 & 3,100 & -.- & 5,280 & 8,910 \\
\hline 11 & -.. & -.- & 2,070 & 2,890 & 2,700 & 1,990 & --- & 5,270 & 7,640 \\
\hline 12 & -.. & 2,320 & 2,040 & 2,150 & 1,480 & 1,610 & 5,290 & 5,690 & 6,190 \\
\hline 13 & 2,340 & 2,350 & 2,080 & 1,950 & 2,130 & 1,620 & 6,670 & 6,170 & 6,770 \\
\hline 14 & 2,140 & 2,440 & 2,090 & 1,920 & 1,970 & 1,590 & 5,610 & 5,930 & 8,100 \\
\hline 15 & 2,580 & 2,380 & 2,110 & 2,280 & 1,590 & 2,350 & 9,240 & 5,220 & 7,910 \\
\hline 16 & 2,640 & 2,410 & 2,430 & 2,020 & 1,670 & 1,850 & ... & 4,900 & 7,330 \\
\hline 17 & 2,620 & 2,470 & 3,780 & 1,970 & 2,110 & 1,860 & 5,330 & 4,770 & 6,070 \\
\hline 18 & 2,610 & 2,360 & 3,460 & 1,930 & 2,010 & 1,890 & 4,020 & 4,760 & 4,210 \\
\hline 19 & 2,240 & 2,350 & 2,540 & 1,930 & 1,820 & 2,770 & 3,650 & 5,080 & 6,210 \\
\hline 20 & 2,160 & 2,320 & 2,270 & 1,800 & --- & 2,040 & 3,870 & 4,980 & 8,080 \\
\hline 21 & 2,470 & 2,190 & 2,130 & 2,230 & --- & 3,410 & 4,760 & 4,470 & 5,420 \\
\hline 22 & 2,380 & 2,220 & 2,180 & 1,940 & 1,500 & 3,420 & 4,850 & 4,430 & 8,520 \\
\hline 23 & 2,350 & -.- & 2,290 & 1,720 & 1,500 & 6,630 & 4,720 & 5,230 & 7,280 \\
\hline 24 & 2,430 & 2,420 & 2,140 & 1,510 & 1,330 & 7,110 & 4,100 & 6,720 & 4,250 \\
\hline 25 & 2,640 & --- & 2,060 & 1,420 & 1,670 & 2,780 & 3,260 & 6,490 & 5,780 \\
\hline 26 & 2,650 & 2,090 & 2,150 & 1,400 & 1,960 & 2,620 & 2,450 & 6,730 & 8,080 \\
\hline 27 & 2,480 & 2,150 & 2,110 & 1,390 & 2,790 & 2,820 & 2,770 & 5,710 & 6,320 \\
\hline 28 & 2,440 & 2,100 & 2,100 & 1,360 & 1,590 & 3,410 & 4,250 & 5,190 & 4,740 \\
\hline 29 & 2,290 & $\ldots$ & 2,070 & 1,470 & 3,530 & 4,080 & 4,090 & 5,460 & 5,010 \\
\hline 30 & 2,400 & -- & 2,190 & 1,410 & 1,990 & 5,150 & 3,950 & 5,120 & 6,550 \\
\hline 31 & 2,300 & $\ldots$ & 2,020 & -.. & 1,800 & --- & 2,180 & 3,930 & -- \\
\hline
\end{tabular}

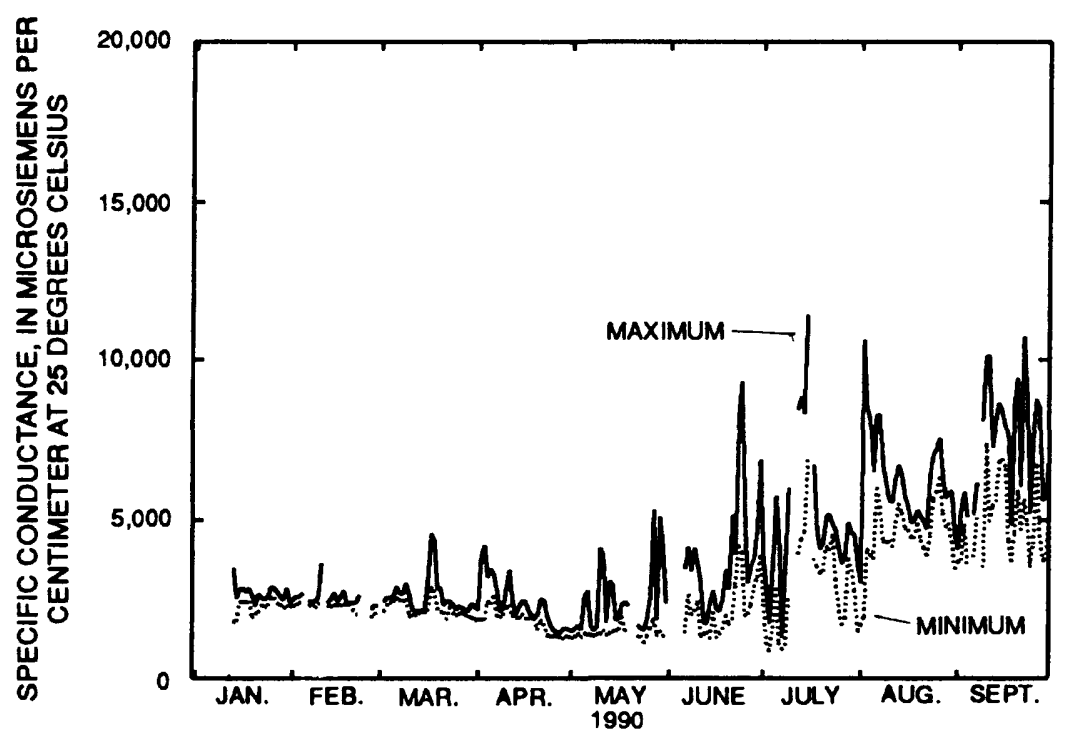


Table 54.--Daily mean values of specific conductance, near bottom, in water at site 5, Currituck Sound at U.S. Highway 158 bridge, October 1990 through April 1991

STATION NUMBER AND NAME: 0204295500, Currituck Sound at U.S. Highway 158 bridge LATITUDE: $36^{\circ} 05^{\prime} 12^{\prime \prime}$ LONGITUDE: $75^{\circ} 46^{\prime} 06^{\prime \prime}$ COUNTY: Currituck PROBE LOCATION: 2 feet above bottom

[Specific conductance, microsiemens per centimeter at 25 degrees Celsius; --., no data]

\begin{tabular}{|c|c|c|c|c|c|c|c|}
\hline Day & Oct. & Nov. & Dec. & Jan. & Feb. & Mar. & Apr. \\
\hline 1 & 5,420 & ... & --- & 4,770 & 3,550 & 3,610 & 5,200 \\
\hline 2 & 6,010 & --- & ... & 4,430 & 3,770 & 5,850 & 5,180 \\
\hline 3 & 6,040 & $\cdots$ & --. & 4,870 & 3,870 & 6,120 & -.. \\
\hline 4 & 7,090 & -.. & -.- & 4,780 & 3,620 & 9,610 & -.- \\
\hline 5 & 6,560 & --. & --- & 4,100 & 3,440 & 7,620 & --- \\
\hline 6 & 6,380 & --- & 6,340 & 4,730 & 3,340 & 8,230 & -.- \\
\hline 7 & 6,790 & $\cdots$ & 6,410 & 4,910 & 3,220 & 9,290 & $\cdots$ \\
\hline 8 & 7,270 & -.. & 5,360 & 3,350 & 2,920 & 4,760 & -.. \\
\hline 9 & 7,120 & --- & 4,510 & 3,250 & 2,770 & 3,610 & $\ldots$ \\
\hline 10 & 8,480 & --- & 5,590 & 3,340 & 2,810 & 3,400 & -- \\
\hline 11 & 12,300 & --. & 5,750 & 3,850 & 3,280 & 3,000 & -.- \\
\hline 12 & 11,300 & $\cdots$ & 6,220 & 5,450 & 2,890 & 2,730 & ... \\
\hline 13 & 11,100 & --. & 6,110 & 4,230 & 3,500 & 3,920 & -.. \\
\hline 14 & 12,200 & -.. & 5,370 & 4,530 & 5,570 & 4,700 & -.- \\
\hline 15 & 11,900 & -- & 6,290 & 6,690 & 4,740 & 3,430 & $\cdots$ \\
\hline 16 & 9,100 & --. & 6,630 & 6,270 & 2,840 & 2,810 & -.- \\
\hline 17 & 9,450 & --- & 6,000 & 6,490 & 3,250 & 4,160 & -- \\
\hline 18 & 13,000 & --. & 6,570 & 5,580 & 3,340 & 5,990 & -. \\
\hline 19 & 11,900 & --- & 6,520 & 4,450 & 3,400 & 5,340 & $\cdots$ \\
\hline 20 & 8,170 & --- & 5,080 & 4,040 & 4,040 & 4,920 & -- \\
\hline 21 & 7,510 & -- & 5,990 & 4,260 & 3,080 & 5,130 & -.- \\
\hline 22 & 8,830 & --- & 6,780 & 2,970 & 3,000 & 6,290 & -.- \\
\hline 23 & 10,900 & --- & 7,560 & 3,410 & 2,720 & 5,530 & -. \\
\hline 24 & 10,400 & $\cdots$ & 9,680 & 3,860 & 2,630 & 5,540 & ... \\
\hline 25 & 8,830 & -- & 5,460 & 3,280 & 2,630 & 3,660 & -- \\
\hline 26 & 4,490 & $\cdots$ & 4,920 & 3,510 & 2,680 & -- & -.- \\
\hline 27 & 3,880 & --- & 4,180 & 4,140 & 3,010 & --- & -- \\
\hline 28 & 7,350 & $\cdots$ & 4,320 & 4,360 & 3,420 & 8,150 & $\cdots$ \\
\hline 29 & 7,240 & $\cdots$ & 5,380 & 4,300 & --- & 7,640 & -- \\
\hline 30 & 7,120 & --- & 6,820 & 4,320 & -- & 7,330 & -- \\
\hline 31 & 7,970 & $\cdots$ & 6,870 & 4,300 & -- & 5,370 & -- \\
\hline
\end{tabular}

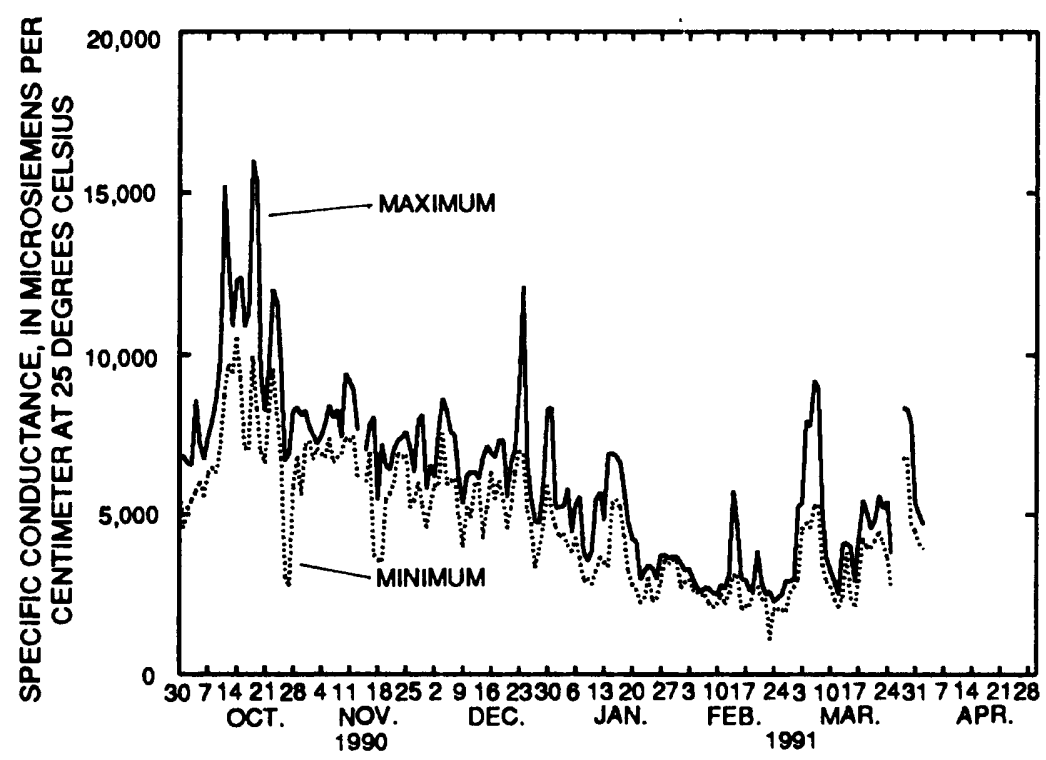


Table 55.--Daily mean values of salinity concentration, near bottom, in water at site 5, Currituck Sound at U.S. Highway 158 bridge, January through September 1990

STATION NUMBER AND NAME: 0204295500, Currituck Sound at U.S. Highway 158 bridge LATITUDE: $36^{\circ} 05^{\prime} 12^{\prime \prime}$ LONGITUDE: $75^{\circ} 46^{\prime} 06^{\prime \prime}$ COUNTY: Currituck

PROBE LOCATION: 2 feet above bottom

[Salinity concentration, parts per thousand; ---, no data]

\begin{tabular}{|c|c|c|c|c|c|c|c|c|c|}
\hline Day & Jan. & Feb. & Mar. & Apr. & May & June & July & Aug. & Sept. \\
\hline 1 & --- & 1.2 & -- & 1.0 & 0.7 & --- & 1.6 & 1.0 & 2.1 \\
\hline 2 & --- & 1.2 & 1.2 & 1.6 & .7 & -.. & .8 & 2.8 & 2.4 \\
\hline 3 & --- & 1.2 & 1.2 & 1.6 & .8 & --- & .7 & 3.2 & 2.9 \\
\hline 4 & --- & 1.3 & 1.2 & 1.4 & .7 & --- & 1.4 & 3.1 & 2.4 \\
\hline 5 & -- & -- & 1.3 & 1.5 & 1.0 & --. & 2.3 & 2.5 & -- \\
\hline 6 & $\ldots$ & 1.2 & 1.4 & 1.5 & .9 & 1.3 & 1.0 & 4.0 & 2.5 \\
\hline 7 & $\ldots$ & 1.2 & 1.3 & 1.1 & .7 & 1.8 & .6 & 3.9 & 3.1 \\
\hline 8 & --- & 1.2 & 1.3 & 1.0 & .7 & 1.3 & .9 & 3.0 & -.. \\
\hline 9 & --- & 1.2 & 1.4 & 1.0 & .7 & 1.8 & 2.5 & 2.9 & 2.5 \\
\hline 10 & --- & 1.5 & 1.1 & 1.2 & 1.5 & 1.6 & --- & 2.8 & 5.0 \\
\hline 11 & -- & --- & 1.0 & 1.5 & 1.4 & 1.0 & --. & 2.8 & 4.2 \\
\hline 12 & --- & 1.2 & 1.0 & 1.1 & .7 & .8 & 2.8 & 3.1 & 3.4 \\
\hline 13 & 1.2 & 1.2 & 1.0 & 1.0 & 1.1 & .8 & 3.6 & 3.3 & 3.7 \\
\hline 14 & 1.1 & 1.2 & 1.0 & 1.0 & 1.0 & .8 & 3.0 & 3.2 & 4.5 \\
\hline 15 & 1.3 & 1.2 & 1.1 & 1.2 & .8 & 1.2 & 5.2 & 2.8 & 4.4 \\
\hline 16 & 1.3 & 1.2 & 1.2 & 1.0 & .8 & .9 & ..- & 2.6 & 4.0 \\
\hline 17 & 1.3 & 1.3 & 2.0 & 1.0 & 1.1 & .9 & 2.9 & 2.5 & 3.3 \\
\hline 18 & 1.3 & 1.2 & 1.8 & 1.0 & 1.0 & .9 & 2.1 & 2.5 & 2.2 \\
\hline 19 & 1.1 & 1.2 & 1.3 & 1.0 & .9 & 1.4 & 1.9 & 2.7 & 3.4 \\
\hline 20 & 1.1 & 1.2 & 1.1 & .9 & -- & 1.0 & 2.0 & 2.7 & 4.5 \\
\hline 21 & 1.3 & 1.1 & 1.1 & 1.1 & --. & 1.8 & 2.5 & 2.4 & 2.9 \\
\hline 22 & 1.2 & 1.1 & 1.1 & 1.0 & .7 & 1.8 & 2.6 & 2.3 & 4.7 \\
\hline 23 & 1.2 & -- & 1.2 & .9 & .7 & 3.6 & 2.5 & 2.8 & 4.0 \\
\hline 24 & 1.2 & 1.2 & 1.1 & .7 & .7 & 3.9 & 2.2 & 3.7 & 2.2 \\
\hline 25 & 1.4 & -- & 1.0 & .7 & .8 & 1.4 & 1.7 & 3.5 & 3.1 \\
\hline 26 & 1.4 & 1.1 & 1.1 & .7 & 1.0 & 1.3 & 1.2 & 3.7 & 4.5 \\
\hline 27 & 1.3 & 1.1 & 1.1 & .7 & 1.4 & 1.4 & 1.4 & 3.1 & 3.4 \\
\hline 28 & 1.2 & 1.1 & 1.1 & .7 & .8 & 1.8 & 2.2 & 2.8 & 2.5 \\
\hline 29 & 1.2 & --- & 1.0 & .7 & 1.8 & 2.1 & 2.1 & 2.9 & 2.7 \\
\hline 30 & 1.2 & --- & 1.1 & .7 & 1.0 & 2.8 & 2.1 & 2.7 & 3.6 \\
\hline 31 & 1.2 & ... & 1.0 & -.-- & .9 & ..- & 1.1 & 2.1 & --. \\
\hline
\end{tabular}

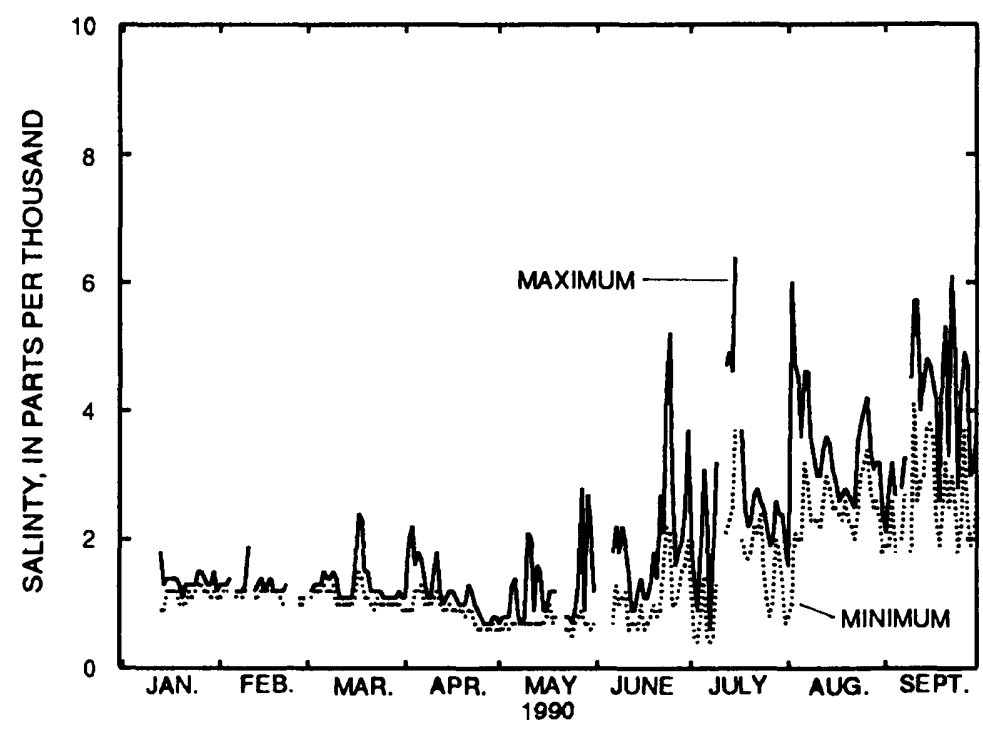


Table 56.--Daily mean values of salinity concentration, near bottom, in water at site 5, Currituck Sound at U.S. Highway 158 bridge, October 1990 through April 1991

STATION NUMBER AND NAME: 0204295500, Currituck Sound at U.S. Highway 158 bridge LATITUDE: $36^{\circ} 05^{\prime} 12^{\prime \prime}$ LONGITUDE: $75^{\circ} 46^{\prime} 06^{\prime \prime}$ COUNTY: Currituck

PROBE LOCATION: 2 feet above bottom

[Salinity concentration, parts per thousand; ---, no data]

\begin{tabular}{|c|c|c|c|c|c|c|c|}
\hline Day & Oct. & Nov. & Dec. & Jan. & Feb. & Mar. & Apr. \\
\hline 1 & 2.9 & $\cdots$ & $\cdots$ & 2.5 & 1.8 & 1.9 & 2.8 \\
\hline 2 & 3.3 & --- & -- & 2.3 & 2.0 & 3.2 & 2.8 \\
\hline 3 & 3.3 & --- & -- & 2.6 & 2.0 & 3.3 & --. \\
\hline 4 & 3.9 & --- & $\cdots$ & 2.5 & 1.9 & 5.4 & --. \\
\hline 5 & 3.6 & --- & -- & 2.2 & 1.8 & 4.2 & --- \\
\hline 6 & 3.5 & --- & 3.4 & 2.5 & 1.7 & 4.6 & --. \\
\hline 7 & 3.7 & --. & 3.5 & 2.6 & 1.7 & 5.2 & --- \\
\hline 8 & 4.0 & --- & 2.9 & 1.7 & 1.5 & 2.5 & --. \\
\hline 9 & 3.9 & --- & 2.4 & 1.7 & 1.4 & 1.9 & -.- \\
\hline 10 & 4.7 & --- & 3.0 & 1.7 & 1.4 & 1.8 & --. \\
\hline 11 & 7.0 & --- & 3.1 & 2.0 & 1.7 & 1.5 & ... \\
\hline 12 & 6.4 & --- & 3.4 & 2.9 & 1.5 & 1.4 & -.. \\
\hline 13 & 6.3 & --- & 3.3 & 2.2 & 1.8 & 2.1 & $\ldots$ \\
\hline 14 & 7.0 & --- & 2.9 & 2.4 & 3.0 & 2.5 & --- \\
\hline 15 & 6.8 & --- & 3.4 & 3.6 & 2.5 & 1.8 & --. \\
\hline 16 & 5.1 & --. & 3.6 & 3.4 & 1.5 & 1.4 & --- \\
\hline 17 & 5.3 & --- & 3.2 & 3.5 & 1.7 & 2.2 & ... \\
\hline 18 & 7.4 & --- & 3.6 & 3.0 & 1.7 & 3.2 & --. \\
\hline 19 & 6.8 & -.- & 3.5 & 2.4 & 1.8 & 2.9 & --- \\
\hline 20 & 4.5 & -.. & 2.7 & 2.1 & 2.1 & 2.6 & $\cdots$ \\
\hline 21 & 4.1 & --. & 3.2 & 2.2 & 1.6 & 2.7 & ... \\
\hline 22 & 4.9 & --. & 3.7 & 1.5 & 1.5 & 3.4 & $\cdots$ \\
\hline 23 & 6.1 & •--- & 4.2 & 1.8 & 1.4 & 3.0 & --- \\
\hline 24 & 5.9 & •-.. & 5.4 & 2.0 & 1.3 & 3.0 & $\ldots$ \\
\hline 25 & 4.9 & --- & 2.9 & 1.7 & 1.3 & 1.9 & --- \\
\hline 26 & 2.4 & --. & 2.6 & 1.8 & 1.4 & --- & -- \\
\hline 27 & 2.0 & --- & 2.2 & 2.2 & 1.6 & -.. & ... \\
\hline 28 & 4.0 & $\cdots$ & 2.3 & 2.3 & 1.8 & 4.5 & --- \\
\hline 29 & 4.0 & --- & 2.9 & 2.3 & --- & 4.2 & --- \\
\hline 30 & 3.9 & -.. & 3.7 & 2.3 & -.. & 4.0 & $\cdots$ \\
\hline 31 & 4.4 & --- & 3.8 & 2.3 & --- & 2.9 & $\cdots$ \\
\hline
\end{tabular}

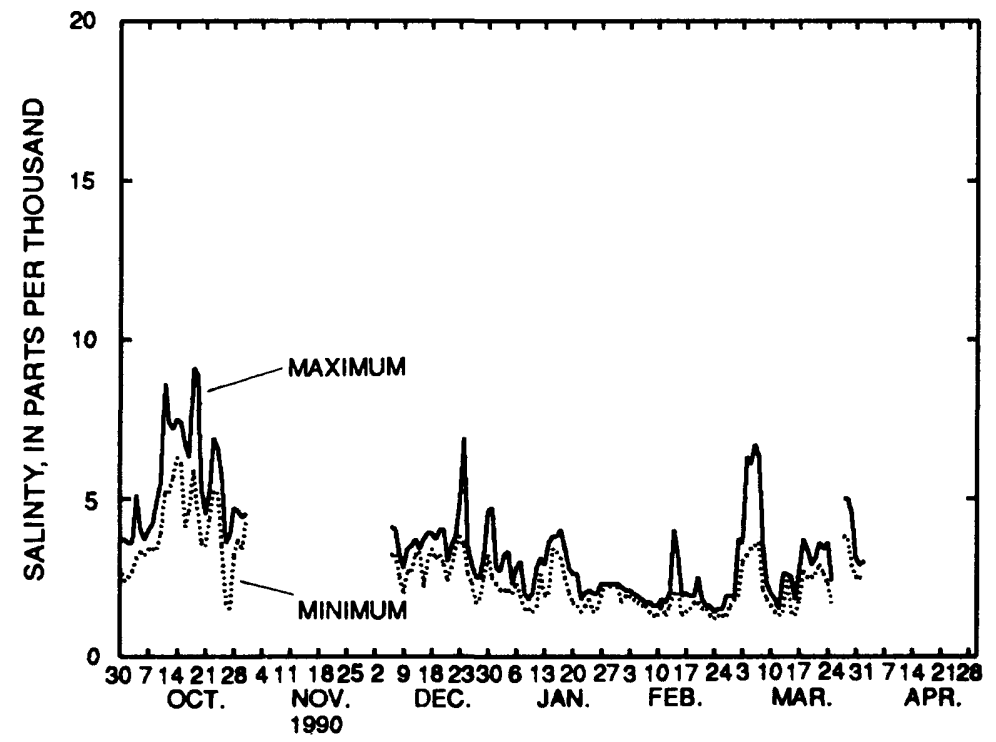


Table 57.--Daily mean values of water temperature, near surface, in water at site 5, Currituck Sound at U.S. Highway 158 bridge, January through September 1990

STATION NUMBER AND NAME: 0204295500, Currituck Sound at U.S. Highway 158 bridge LATITUDE: $36^{\circ} 05^{\prime} 12^{\prime \prime}$ LONGITUDE: $75^{\circ} 46^{\prime} 06^{\prime \prime}$ COUNTY: Currituck

PROBE LOCATION: 7 feet above bottom

[Water temperature, degrees Celsius; ---, no data]

\begin{tabular}{|c|c|c|c|c|c|c|c|c|c|}
\hline Day & Jan. & Feb. & Mar. & Apr. & May & June & July & Aug. & Sept. \\
\hline 1 & --- & 11.6 & -- & 12.0 & 22.8 & 22.4 & 28.1 & 29.0 & 27.0 \\
\hline 2 & ..- & 12.5 & 8.6 & 13.1 & 22.8 & -.- & 27.0 & 28.0 & 27.5 \\
\hline 3 & --- & 13.2 & 9.1 & 13.5 & 21.5 & --- & 26.8 & 27.9 & 27.2 \\
\hline 4 & -- & 13.8 & 8.5 & 13.1 & 21.0 & --- & 26.6 & 28.1 & 26.1 \\
\hline 5 & --- & -- & 8.4 & 13.2 & 21.4 & 23.8 & 27.4 & 27.8 & ... \\
\hline 6 & -.- & 10.8 & 9.9 & 14.1 & 20.7 & 23.4 & 27.8 & 27.3 & 25.2 \\
\hline 7 & $\ldots$ & 10.9 & 8.1 & 13.7 & 20.1 & 24.0 & 27.9 & 26.6 & 26.1 \\
\hline 8 & --. & 11.6 & 7.4 & 13.1 & 20.4 & 25.4 & 27.5 & 26.3 & -- \\
\hline 9 & --- & 11.8 & 8.2 & 13.3 & 20.7 & 26.7 & 27.9 & 26.5 & 25.8 \\
\hline 10 & $\cdots$ & 13.6 & 9.3 & 14.2 & 20.7 & 27.1 & -- & 26.9 & 26.3 \\
\hline 11 & $\cdots$ & --- & 10.7 & 15.2 & 19.9 & 25.9 & --- & 27.8 & 26.5 \\
\hline 12 & $\ldots$ & 11.8 & 12.6 & 14.7 & 19.6 & 23.3 & 29.3 & 28.8 & 26.3 \\
\hline 13 & 5.6 & 11.4 & 14.4 & 14.4 & 20.4 & 22.6 & 28.6 & 29.0 & 26.5 \\
\hline 14 & 5.2 & 12.2 & 15.5 & 14.3 & 21.0 & 22.9 & 28.3 & 29.2 & 26.7 \\
\hline 15 & 5.2 & 12.8 & 16.2 & 15.4 & 21.3 & 22.2 & 27.9 & 29.3 & 26.2 \\
\hline 16 & 6.3 & 14.5 & 17.1 & 15.7 & 22.3 & 21.8 & -- & 29.2 & 26.5 \\
\hline 17 & 6.7 & 15.5 & 17.9 & 16.8 & 23.2 & 22.2 & 27.9 & 29.3 & 24.8 \\
\hline 18 & 7.4 & 13.3 & 18.0 & 15.5 & 23.1 & 23.9 & 27.9 & 29.7 & 22.5 \\
\hline 19 & 8.0 & 12.9 & 17.6 & 14.8 & 22.7 & 24.9 & 28.2 & 30.1 & 21.9 \\
\hline 20 & 8.3 & 11.5 & 16.1 & 15.4 & -.. & 25.8 & 27.8 & 29.9 & 21.9 \\
\hline 21 & 8.9 & 10.1 & 12.4 & 16.7 & --- & 25.5 & 27.8 & 28.3 & 21.7 \\
\hline 22 & 9.5 & 10.8 & 12.8 & 17.1 & 21.0 & 26.6 & 28.2 & 27.3 & 22.3 \\
\hline 23 & 9.4 & $\ldots$ & 13.5 & 17.9 & 18.6 & 27.1 & 29.2 & 27.6 & 22.7 \\
\hline 24 & 9.9 & 12.6 & 13.2 & 19.4 & 19.6 & 27.3 & 29.0 & 27.5 & 21.1 \\
\hline 25 & 11.1 & $\cdots$ & 12.2 & 19.9 & 20.3 & 26.6 & 28.6 & 27.7 & 21.1 \\
\hline 26 & 12.1 & 5.8 & 11.6 & 21.2 & 20.9 & 26.4 & 27.7 & 28.0 & 21.0 \\
\hline 27 & 10.5 & 6.0 & 11.5 & 22.8 & 21.4 & 26.5 & 27.6 & 28.4 & 21.4 \\
\hline 28 & 10.2 & 6.4 & 11.1 & 23.3 & 20.2 & 27.2 & 27.7 & 29.2 & 21.7 \\
\hline 29 & 10.6 & --- & 11.2 & 22.6 & 20.4 & 27.7 & 27.8 & 29.9 & 22.2 \\
\hline 30 & 11.3 & -.- & 11.3 & 22.0 & 20.8 & 28.0 & 28.0 & 29.2 & 22.5 \\
\hline 31 & 11.2 & -.. & 11.6 & $\ldots$ & 21.5 & -.. & 28.7 & 27.8 & -.- \\
\hline
\end{tabular}

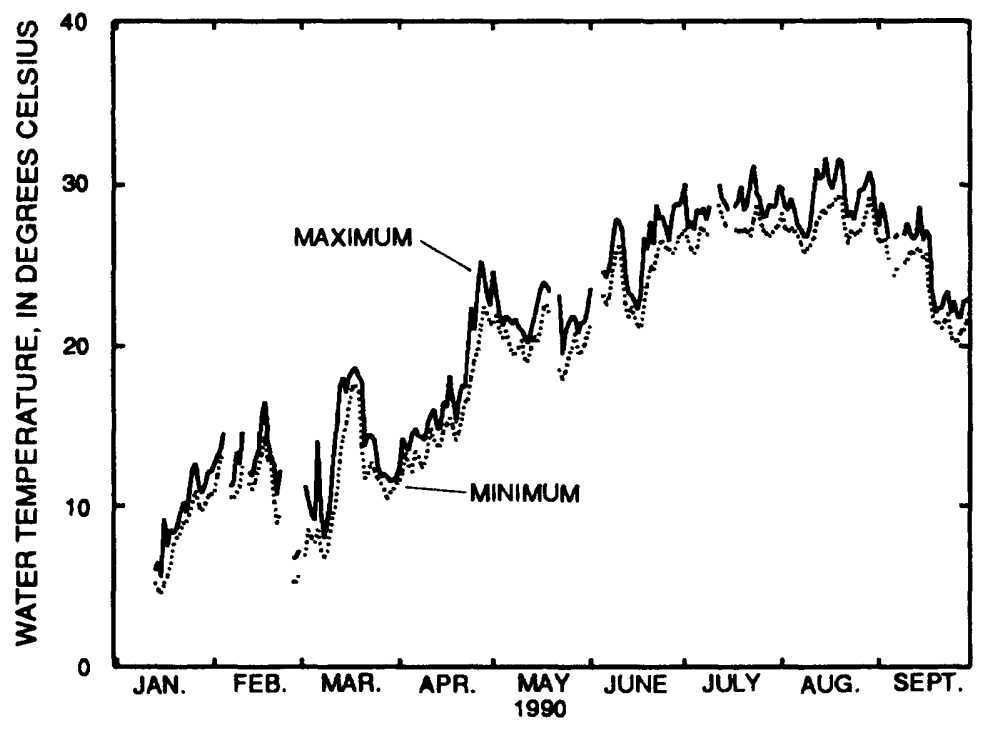


Table 58.--Daily mean values of water temperature, near surface, in water at site 5, Currituck Sound at U.S. Highway 158 bridge, October 1990 through April 1991

STATION NUMBER AND NAME: 0204295500, Currituck Sound at U.S. Highway 158 bridge LATITUDE: $36^{\circ} 05^{\prime} 12^{\prime \prime}$ LONGITUDE: $75^{\circ} 46^{\circ} 06^{\prime \prime}$ COUNTY: Currituck

PROBE LOCATION: 7 feet above bottom

[Water temperature, degrees Celsius; ---, no data]

\begin{tabular}{|c|c|c|c|c|c|c|c|}
\hline Day & Oct. & Nov. & Dec. & Jan. & Feb. & Mar. & Apr. \\
\hline 1 & 22.2 & 15.0 & 10.1 & 9.6 & 6.8 & 8.7 & 13.4 \\
\hline 2 & 22.4 & 16.0 & 10.4 & 9.5 & 7.0 & 10.7 & 14.2 \\
\hline 3 & 22.1 & 16.8 & 10.9 & 9.5 & 8.0 & 11.8 & --- \\
\hline 4 & 22.3 & 16.8 & 12.2 & 9.2 & 8.6 & 12.5 & --- \\
\hline 5 & 22.6 & 16.9 & 10.1 & 8.6 & 9.0 & 12.9 & --- \\
\hline 6 & 22.9 & 17.1 & 9.0 & 8.8 & 9.4 & 12.8 & --- \\
\hline 7 & 23.7 & 16.5 & 9.1 & 9.2 & 9.4 & 13.0 & --. \\
\hline 8 & 24.7 & 15.4 & 8.7 & 8.8 & 9.8 & 11.9 & -.. \\
\hline 9 & 24.7 & 14.1 & 8.3 & 8.7 & 9.5 & 10.3 & --- \\
\hline 10 & 25.0 & 15.1 & 8.0 & 8.2 & 9.1 & 9.7 & --- \\
\hline 11 & 24.7 & 14.2 & 8.1 & 8.6 & 8.8 & 8.5 & --- \\
\hline 12 & 24.7 & 13.2 & 8.4 & 9.7 & 7.6 & 7.7 & --- \\
\hline 13 & 25.2 & 12.5 & 8.9 & 9.1 & 7.2 & 8.4 & --. \\
\hline 14 & 25.6 & --- & 8.8 & 8.3 & 8.8 & 8.8 & $\cdots$ \\
\hline 15 & 25.2 & 11.3 & 8.8 & 8.5 & 8.8 & 8.0 & $-\cdots$ \\
\hline 16 & 23.6 & 11.6 & 9.4 & 9.2 & 5.8 & 7.7 & -- \\
\hline 17 & 22.8 & 11.7 & 9.4 & 9.7 & 4.8 & 9.0 & $\ldots$ \\
\hline 18 & 22.7 & 9.8 & 10.0 & 9.3 & 5.3 & 9.7 & --- \\
\hline 19 & 20.7 & 8.8 & 11.1 & 8.8 & 5.8 & 10.1 & $-\cdots$ \\
\hline 20 & 18.7 & 9.1 & 10.8 & 8.8 & 7.8 & 10.7 & -- \\
\hline 21 & 18.5 & 9.2 & 11.8 & 8.9 & 8.7 & 11.5 & --- \\
\hline 22 & 19.2 & 10.0 & 12.9 & 7.1 & 9.6 & 12.6 & -- \\
\hline 23 & 19.9 & 10.2 & 13.6 & 6.0 & 9.6 & 12.6 & --- \\
\hline 24 & 20.1 & 10.4 & 14.2 & 6.0 & 9.2 & 12.6 & --- \\
\hline 25 & 19.6 & 10.5 & 11.8 & 5.3 & 9.2 & 11.4 & -- \\
\hline 26 & 15.8 & 10.9 & 10.0 & 4.7 & 8.7 & --- & --- \\
\hline 27 & 12.8 & 11.4 & 8.2 & 5.4 & 7.4 & --- & --- \\
\hline 28 & 13.2 & 12.1 & 8.9 & 6.2 & 7.6 & 16.9 & $\cdots$ \\
\hline 29 & 12.8 & 13.0 & 9.3 & 6.3 & --- & 17.6 & -- \\
\hline 30 & 12.5 & 10.6 & 10.2 & 6.9 & -- & 17.2 & $\ldots$ \\
\hline 31 & 14.0 & -.- & 11.2 & 7.5 & --- & 14.3 & --- \\
\hline
\end{tabular}

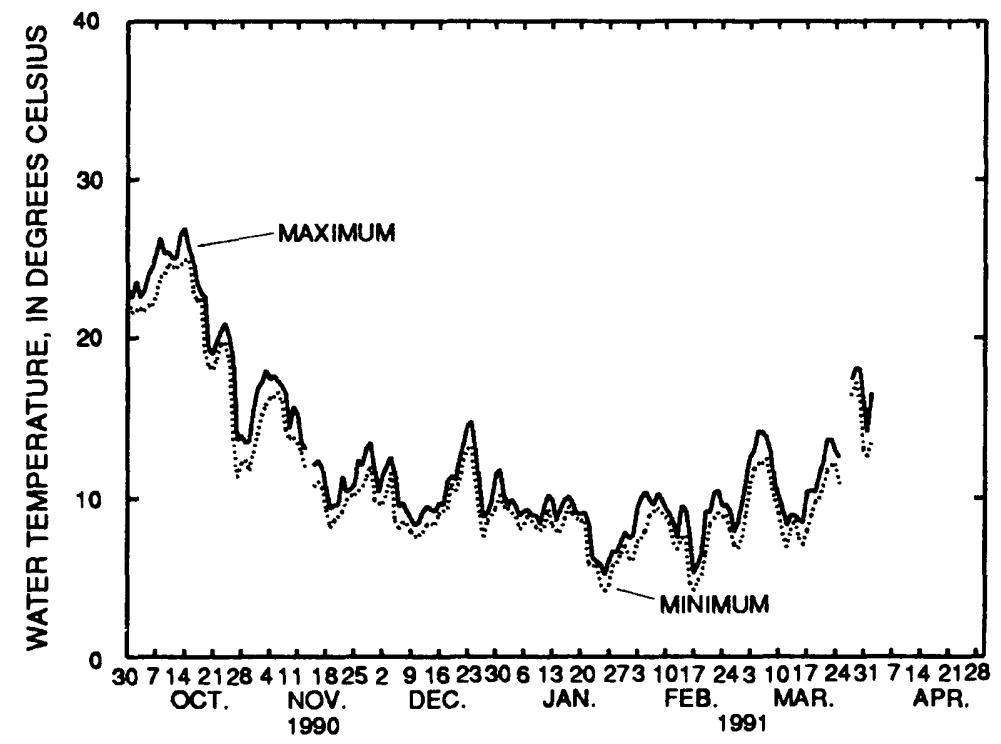


Table 59.--Daily mean values of dissolved-oxygen concentration, near surface, in water at site 5, Currituck Sound at U.S. Highway 158 bridge, January through September 1990

STATION NUMBER AND NAME: 0204295500 , Currituck Sound at U.S. Highway 158 bridge LATITUDE: $36^{\circ} 05^{\prime} 12^{\prime \prime}$ LONGITUDE: $7^{\circ} 46^{\prime} 06^{\prime \prime}$ COUNTY: Currituck

PROBE LOCATION: 7 feet above bottom

[Dissolved-oxygen concentration, milligrams per liter; ---, no data]

\begin{tabular}{|c|c|c|c|c|c|c|c|c|c|}
\hline Day & Jan. & Feb. & Mar. & Apr. & May & June & July & Aug. & Sept. \\
\hline 1 & -.. & 11.2 & -.- & 10.8 & 8.5 & 9.4 & 7.7 & 7.7 & 8.2 \\
\hline 2 & -.- & 11.2 & 11.3 & 11.0 & 8.6 & --- & 7.5 & 7.9 & 8.5 \\
\hline 3 & --- & 11.0 & 11.3 & 10.4 & 8.7 & --- & 7.5 & 7.9 & 8.2 \\
\hline 4 & --- & 10.6 & 11.0 & 10.2 & 8.8 & -- & 8.3 & 8.0 & 8.2 \\
\hline 5 & -- & -.. & 11.0 & 10.6 & 8.9 & 9.0 & 7.9 & 8.4 & -- \\
\hline 6 & --- & 10.5 & 11.1 & 10.4 & 8.8 & 8.9 & 7.8 & 7.7 & 8.5 \\
\hline 7 & --- & 10.8 & 11.1 & 9.9 & 9.2 & 9.1 & 7.6 & 7.7 & 8.3 \\
\hline 8 & --- & 11.2 & 11.2 & 10.3 & 9.4 & 8.7 & 7.8 & 7.5 & -.- \\
\hline 9 & --- & 11.2 & 11.3 & 10.5 & 8.9 & 8.7 & 8.1 & 7.7 & 7.8 \\
\hline 10 & --- & 10.1 & 11.2 & 10.5 & 8.4 & 8.5 & -- & 7.7 & 8.2 \\
\hline 11 & $\ldots$ & -.. & 11.3 & 9.8 & 8.5 & 8.6 & -.- & 8.2 & 7.6 \\
\hline 12 & --- & 10.3 & 11.4 & 10.0 & 8.8 & 9.0 & 7.3 & 8.0 & 7.7 \\
\hline 13 & 12.1 & 10.5 & 11.3 & 10.3 & 8.7 & 9.0 & 7.2 & 7.8 & 7.4 \\
\hline 14 & 12.0 & 10.6 & 11.4 & 10.4 & $\ldots$ & 8.1 & 7.4 & 7.4 & 7.6 \\
\hline 15 & 12.1 & 10.6 & 11.0 & 10.3 & -- & 9.0 & 7.1 & 7.3 & 7.9 \\
\hline 16 & 12.0 & 10.1 & 10.0 & 10.2 & -- & 9.4 & $\cdots$ & 7.4 & 8.2 \\
\hline 17 & 11.9 & 9.7 & 9.2 & 10.2 & --. & 9.6 & 8.4 & 7.4 & 8.3 \\
\hline 18 & 12.2 & 10.1 & 9.1 & 10.0 & -- & 9.2 & 7.8 & 7.4 & 8.2 \\
\hline 19 & 11.8 & 10.2 & 9.5 & 10.3 & --- & 9.4 & 7.7 & 7.6 & 8.5 \\
\hline 20 & 11.4 & 10.4 & 9.4 & 10.5 & --. & 9.4 & 7.8 & 7.5 & 8.6 \\
\hline 21 & 11.3 & 10.7 & 10.1 & 10.2 & ... & 8.7 & 7.5 & 7.2 & 8.5 \\
\hline 22 & 11.2 & 10.9 & 10.4 & 9.9 & 8.0 & 7.2 & 7.6 & 7.8 & 8.6 \\
\hline 23 & 11.0 & --. & 10.3 & 9.9 & 8.6 & 7.3 & 7.7 & 7.8 & 8.5 \\
\hline 24 & 11.3 & 10.1 & 10.2 & 9.5 & 9.1 & 7.4 & 7.5 & 8.0 & 8.4 \\
\hline 25 & 11.3 & --- & 10.1 & 9.2 & 8.8 & 7.7 & 7.6 & 8.1 & 8.6 \\
\hline 26 & 10.5 & 11.7 & 10.3 & 9.0 & 9.0 & 7.4 & 7.6 & 8.3 & 8.8 \\
\hline 27 & 10.8 & 11.6 & 10.6 & 8.9 & 8.9 & 7.6 & 7.3 & 8.5 & 8.8 \\
\hline 28 & 11.1 & 11.9 & 10.8 & 8.7 & 8.9 & 7.7 & 7.3 & 8.6 & 8.4 \\
\hline 29 & 11.2 & -- & 10.8 & 8.4 & 9.1 & 8.0 & 7.4 & 8.3 & 8.0 \\
\hline 30 & 11.0 & --. & 10.6 & 8.3 & 8.9 & 7.7 & 7.0 & 7.8 & 7.5 \\
\hline 31 & 11.2 & -- & 10.8 & ... & 8.8 & --- & 7.4 & 7.7 & -- \\
\hline
\end{tabular}

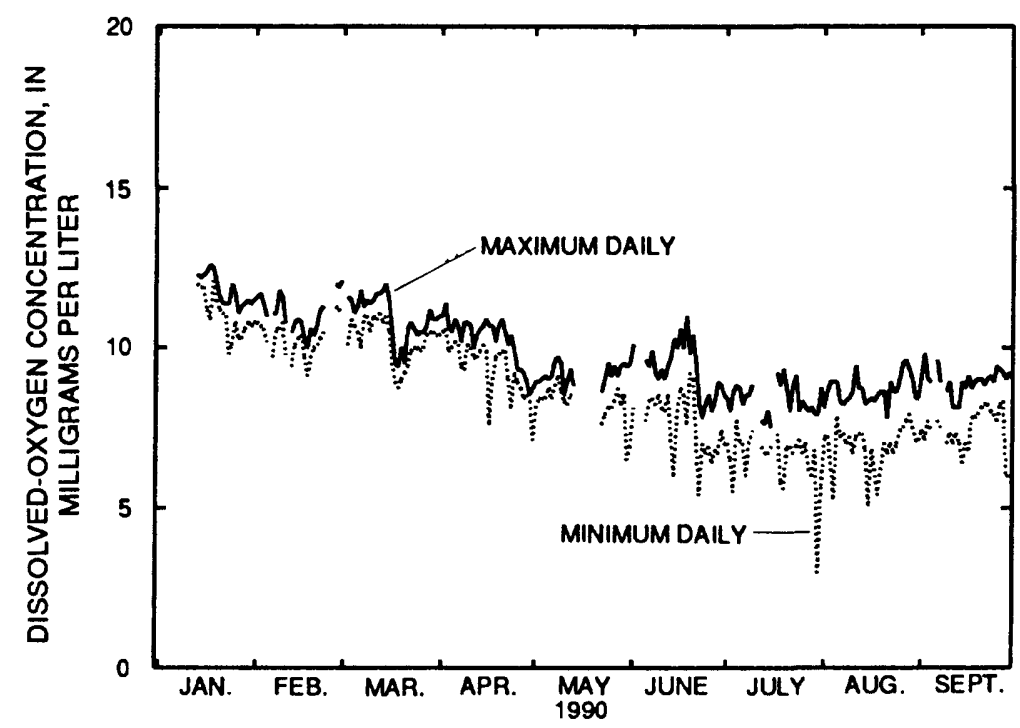


Table 60.--Daily mean values of dissolved-oxygen concentration, near surface, in water at site 5, Currituck Sound at U.S. Highway 158 bridge, October 1990 through April 1991

STATION NUMBER AND NAME: 0204295500, Currituck Sound at U.S. Highway 158 bridge LATITUDE: $36^{\circ} 05^{\prime} 12^{\prime \prime}$ LONGITUDE: $75^{\circ} 46^{\prime} 06^{\prime \prime}$ COUNTY: Currituck PROBE LOCATION: 7 feet above bottom

[Dissolved-oxygen concentration, milligrams per liter; ---, no data]

\begin{tabular}{|c|c|c|c|c|c|c|c|}
\hline Day & Oct. & Nov. & Dec. & Jan. & Feb. & Mar. & Apr. \\
\hline 1 & 8.5 & 8.7 & 11.1 & 10.9 & 11.3 & --- & 9.9 \\
\hline 2 & 9.2 & 9.2 & 11.0 & 10.6 & 10.4 & --- & 10.5 \\
\hline 3 & 9.1 & 10.4 & 11.5 & 9.2 & 11.2 & --- & --- \\
\hline 4 & 9.2 & 10.9 & 11.3 & 10.3 & 11.7 & --- & -- \\
\hline 5 & 8.8 & 9.9 & 11.4 & 10.2 & 11.5 & --- & -- \\
\hline 6 & 9.3 & 10.4 & 11.5 & 9.6 & 9.2 & --- & --- \\
\hline 7 & 9.2 & 9.1 & 11.2 & 9.9 & 9.8 & $\ldots$ & -.. \\
\hline 8 & 9.2 & 10.2 & 11.9 & 11.1 & 11.4 & ... & --- \\
\hline 9 & 8.8 & 9.8 & 11.9 & 11.1 & 10.6 & $\cdots$ & --- \\
\hline 10 & 8.5 & 10.1 & 11.8 & 11.2 & 10.5 & -- & -- \\
\hline 11 & 8.4 & 10.1 & 11.3 & 11.2 & 10.5 & -.- & -- \\
\hline 12 & 8.4 & 9.7 & 9.5 & 10.8 & 11.0 & $\cdots$ & --- \\
\hline 13 & 8.2 & 10.5 & 11.8 & 11.0 & 11.2 & --- & -- \\
\hline 14 & 8.7 & $\cdots$ & 12.1 & 10.8 & 10.8 & $\cdots$ & --- \\
\hline 15 & 8.5 & 10.5 & 11.6 & 11.2 & --- & --- & -- \\
\hline 16 & 8.8 & 11.2 & 11.7 & 11.1 & $\cdots$ & --- & -.- \\
\hline 17 & 8.8 & 11.3 & 11.1 & 11.0 & $\cdots$ & --- & --- \\
\hline 18 & 8.6 & 11.5 & 11.8 & 11.0 & $\cdots$ & -- & --- \\
\hline 19 & 9.0 & 11.5 & 11.5 & 10.9 & $\cdots$ & --. & $\cdots$ \\
\hline 20 & 9.2 & 11.4 & 11.6 & 10.9 & -- & -- & -- \\
\hline 21 & 8.3 & 11.5 & 11.2 & 11.0 & --- & --- & --- \\
\hline 22 & 7.9 & 10.9 & 11.0 & 11.1 & -- & -- & --. \\
\hline 23 & 8.9 & 11.5 & 11.4 & 11.2 & --- & $\cdots$ & -- \\
\hline 24 & 8.7 & 11.5 & 10.9 & 11.5 & -- & -- & --- \\
\hline 25 & 8.9 & 11.4 & 11.0 & 11.8 & $\cdots$ & --- & $\cdots$ \\
\hline 26 & 10.0 & 11.3 & 11.4 & 11.6 & $\cdots$ & --- & -.- \\
\hline 27 & 10.6 & 10.8 & 12.0 & 11.9 & $\cdots$ & -- & --- \\
\hline 28 & 10.8 & 11.1 & 11.6 & 10.1 & --- & 9.2 & --- \\
\hline 29 & 11.0 & 11.0 & 11.1 & 11.2 & $\cdots$ & 9.1 & --- \\
\hline 30 & 10.9 & 11.4 & 11.5 & 10.8 & --- & 8.9 & -.. \\
\hline 31 & 10.5 & $\cdots$ & 11.2 & 11.8 & $\cdots$ & 9.6 & -.- \\
\hline
\end{tabular}

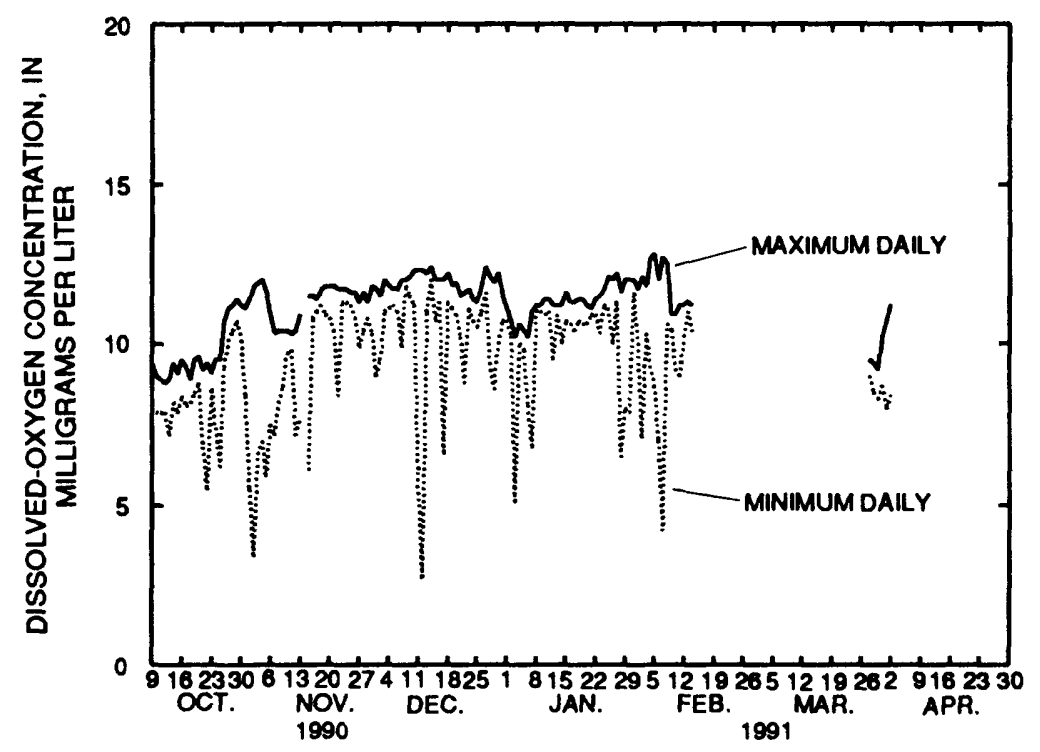


Table 61.--Daily mean values of dissolved-oxygen concentration, mid-depth, in water at site 5, Currituck Sound at U.S. Highway 158 bridge, January through September 1990

STATION NUMBER AND NAME: 0204295500, Currituck Sound at U.S. Highway 158 bridge LATITUDE: $36^{\circ} 05^{\prime} 12^{\prime \prime}$ LONGITUDE: $75^{\circ} 46^{\circ} 06^{\prime \prime}$ COUNTY: Currituck

PROBE LOCATION: 5 feet above bottom

[Dissolved-oxygen concentration, milligrams per liter; ---, no data]

\begin{tabular}{|c|c|c|c|c|c|c|c|c|c|}
\hline Day & Jan. & Feb. & Mar. & Apr. & May & June & July & Aug. & Sept. \\
\hline 1 & -.. & 10.9 & --. & 10.3 & 8.0 & --. & 7.2 & 7.7 & 8.0 \\
\hline 2 & --- & 10.5 & 10.4 & 10.2 & 8.5 &..- & 7.2 & 7.4 & 8.2 \\
\hline 3 & -- & 10.3 & 11.2 & 10.0 & 8.5 & --- & 6.7 & 7.0 & 8.1 \\
\hline 4 & -- & 10.1 & 11.3 & 10.0 & 8.6 & --- & 8.0 & 6.8 & 8.1 \\
\hline 5 & ... & --- & 10.9 & 10.2 & 8.8 & --- & 7.7 & 8.1 &.- \\
\hline 6 & ..- & 10.1 & 10.5 & 10.1 & 8.7 & 8.5 & 7.5 & 7.8 & 8.6 \\
\hline 7 & --- & 10.4 & 11.5 & 9.6 & 9.0 & 9.2 & 7.2 & 7.3 & 8.2 \\
\hline 8 & -- & 10.2 & 11.4 & 9.8 & 9.2 & 8.8 & 7.6 & 6.9 & --- \\
\hline 9 & $\ldots$ & 10.7 & 11.6 & 10.0 & 9.0 & 8.8 & 7.9 & 7.2 & 7.4 \\
\hline 10 & -- & 9.7 & 11.4 & 10.3 & 8.6 & 8.6 & -- & 7.0 & 7.8 \\
\hline 11 & -.. & -.- & 11.2 & 9.5 & 8.8 & 8.8 & --- & 7.9 & 7.6 \\
\hline 12 & --- & 9.8 & 10.9 & 9.4 & 9.0 & 9.2 & 5.7 & 7.7 & 7.9 \\
\hline 13 & 11.9 & 10.0 & 10.5 & 10.0 & 9.0 & 9.0 & 5.5 & 7.7 & 7.5 \\
\hline 14 & 11.7 & 10.1 & 10.1 & 10.0 & 8.8 & 8.1 & 5.9 & 7.2 & 7.5 \\
\hline 15 & 11.9 & 10.2 & 10.8 & 8.3 & 8.3 & 9.0 & 5.8 & 6.2 & 7.9 \\
\hline 16 & 11.5 & 9.7 & 9.9 & 8.8 & 8.8 & 9.1 & --. & 6.4 & 7.6 \\
\hline 17 & 11.4 & 9.3 & 9.8 & 9.8 & 8.6 & 9.5 & 6.0 & 6.5 & 8.3 \\
\hline 18 & 12.1 & 9.7 & 9.4 & 9.8 & 8.3 & 8.4 & 5.8 & 6.5 & 8.4 \\
\hline 19 & 11.8 & 9.6 & 9.5 & 10.0 & 8.1 & 8.8 & 5.9 & 7.0 & 8.7 \\
\hline 20 & 11.4 & 10.2 & 9.8 & 10.2 & -- & 8.4 & 7.2 & 7.1 & 8.7 \\
\hline 21 & 11.5 & 10.4 & 10.7 & 10.1 & --. & 8.6 & 7.1 & 6.9 & 8.6 \\
\hline 22 & 11.2 & 10.7 & 10.3 & 9.8 & -.. & 7.4 & 7.1 & 7.2 & 8.9 \\
\hline 23 & 10.9 & --- & 9.8 & 9.6 & --- & 8.0 & 7.1 & 7.0 & 8.8 \\
\hline 24 & 10.8 & 9.9 & 9.9 & 9.3 & ... & 7.9 & 7.5 & 7.2 & 8.8 \\
\hline 25 & 11.6 & --- & 9.8 & 9.0 & --. & 7.9 & 7.5 & 7.0 & 9.1 \\
\hline 26 & 10.7 & 11.7 & 9.9 & 8.7 & -.. & 7.4 & 7.5 & 7.4 & 9.1 \\
\hline 27 & 10.5 & 11.3 & 10.3 & 7.8 & -.. & 7.5 & 7.1 & 7.6 & 9.1 \\
\hline 28 & I0.9 & 11.8 & 10.2 & 8.4 & -.- & 7.7 & 7.2 & 8.0 & 8.9 \\
\hline 29 & 11.1 & -.- & 10.5 & 8.3 & --- & 8.2 & 7.6 & 7.9 & 8.8 \\
\hline 30 & 10.8 & --- & 10.4 & 8.0 & ... & 7.4 & 7.3 & 7.6 & 8.6 \\
\hline 31 & 11.2 & -.. & 10.1 & --- & --. & --- & 7.6 & 7.5 & $\ldots$ \\
\hline
\end{tabular}

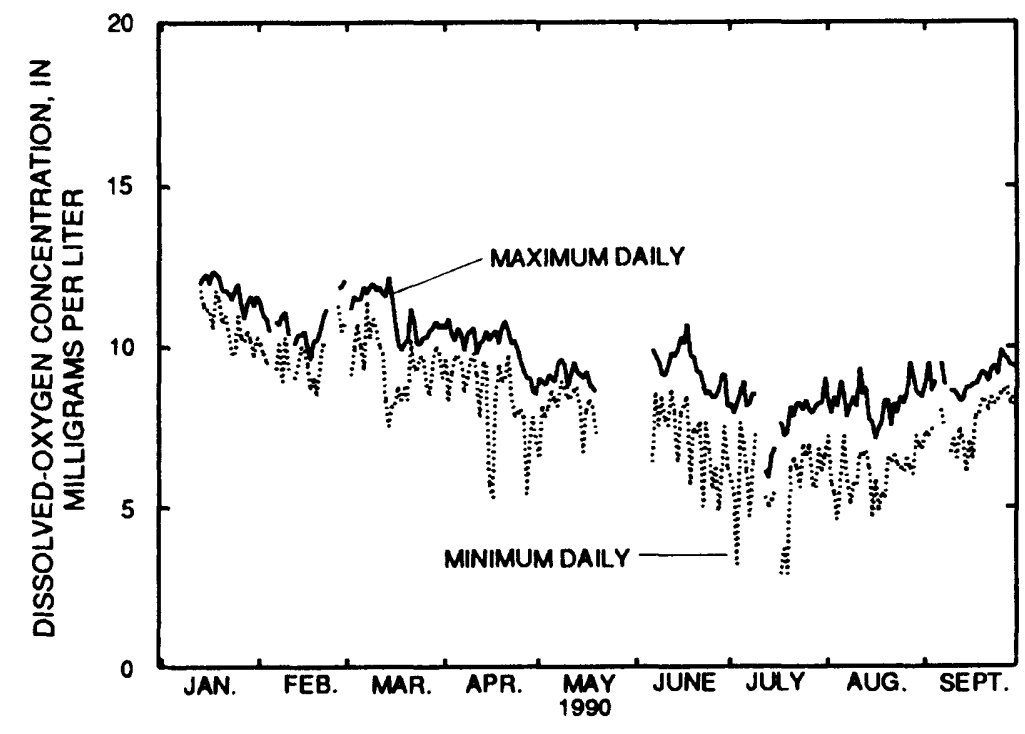


Table 62.--Daily mean values of dissolved-oxygen concentration, mid-depth, in water at site 5, Currituck Sound at US. Highway 158 bridge, October 1990 through April 1991

STATION NUMBER AND NAME: 0204295500, Currituck Sound at U.S. Highway 158 bridge LATITUDE: $36^{\circ} 05^{\prime} 12^{\prime \prime}$ LONGITUDE: $75^{\circ} 46^{\prime} 06^{\prime \prime}$ COUNTY: Currituck

PROBE LOCATION: 5 feet above bottom

[Dissolved-oxygen concentration, milligrams per liter; ---, no data]

\begin{tabular}{|c|c|c|c|c|c|c|c|}
\hline Day & Oct. & Nov. & Dec. & Jan. & Feb. & Mar. & Apr. \\
\hline 1 & 8.9 & --- & 10.5 & 10.0 & 11.2 & 10.6 & 9.8 \\
\hline 2 & 9.1 & --. & 9.8 & 10.1 & 11.0 & 10.7 & 9.6 \\
\hline 3 & 9.1 & --. & 11.0 & 9.7 & 10.8 & -- & -- \\
\hline 4 & 8.9 & $\ldots$ & 10.8 & 10.5 & 10.7 & -.. & $\cdots$ \\
\hline 5 & 8.5 & $\cdots$ & 11.0 & 10.6 & 10.9 & --- & -- \\
\hline 6 & 8.7 & --- & 10.9 & 10.1 & 10.0 & $\ldots$ & ... \\
\hline 7 & 8.7 & --. & 10.3 & 10.5 & 10.8 & --- & $\ldots$ \\
\hline 8 & 8.4 & -.- & 11.0 & 11.0 & 11.2 & --. & -.. \\
\hline 9 & 8.1 & --- & 11.0 & 11.1 & 10.5 & --- & -.. \\
\hline 10 & 7.8 & --. & 10.9 & 10.8 & 10.4 & --- & $\cdots$ \\
\hline 11 & 7.8 & --- & 10.8 & 10.9 & 10.7 & --- & -.. \\
\hline 12 & 7.5 & --- & 10.1 & 10.3 & 11.0 & -.. & --- \\
\hline 13 & 6.7 & --. & 10.6 & 10.6 & 11.1 & --- & -.. \\
\hline 14 & 7.4 & --. & 11.3 & 10.4 & 10.7 & --- & -.. \\
\hline 15 & 7.7 & 10.3 & 10.7 & 10.6 & 10.6 & --- & --- \\
\hline 16 & 8.0 & 10.4 & 10.9 & 10.7 & 11.3 & -.. & --- \\
\hline 17 & 7.8 & 10.6 & 10.5 & 10.6 & 11.7 & --- & --. \\
\hline 18 & 7.8 & 10.9 & 10.9 & 10.6 & 11.3 & -.- & -.. \\
\hline 19 & 8.1 & 10.9 & 10.6 & 10.5 & 11.8 & --- & -- \\
\hline 20 & 8.4 & 10.7 & 10.6 & 10.5 & 11.8 & --- & --- \\
\hline 21 & --. & 10.7 & 9.8 & 10.7 & 11.3 & $\ldots$ & -.. \\
\hline 22 & --- & 10.3 & 8.8 & 10.9 & 11.0 & --- & ... \\
\hline 23 & ... & •10.8 & 9.5 & 10.9 & 10.8 & -.. & --- \\
\hline 24 & --. & 10.9 & 9.6 & 11.1 & 10.5 & -.. & -.. \\
\hline 25 & $\cdots$ & 10.6 & 9.5 & 11.6 & 10.4 & --- & -- \\
\hline 26 & --- & 10.1 & 10.0 & 11.5 & 10.5 & -.. & --. \\
\hline 27 & --- & 8.6 & 10.4 & 11.5 & 10.9 & -.. & -.. \\
\hline 28 & --- & 9.9 & 10.0 & 10.5 & 11.1 & $\cdots$ & -- \\
\hline 29 & --- & 10.0 & 9.9 & 10.9 & -.. & 9.2 & -.. \\
\hline 30 & -.. & 10.4 & 10.0 & 10.9 & $\cdots$ & 9.0 & -.- \\
\hline 31 & -.. & --. & 9.8 & 11.6 & $\ldots$ & 9.5 & -.- \\
\hline
\end{tabular}

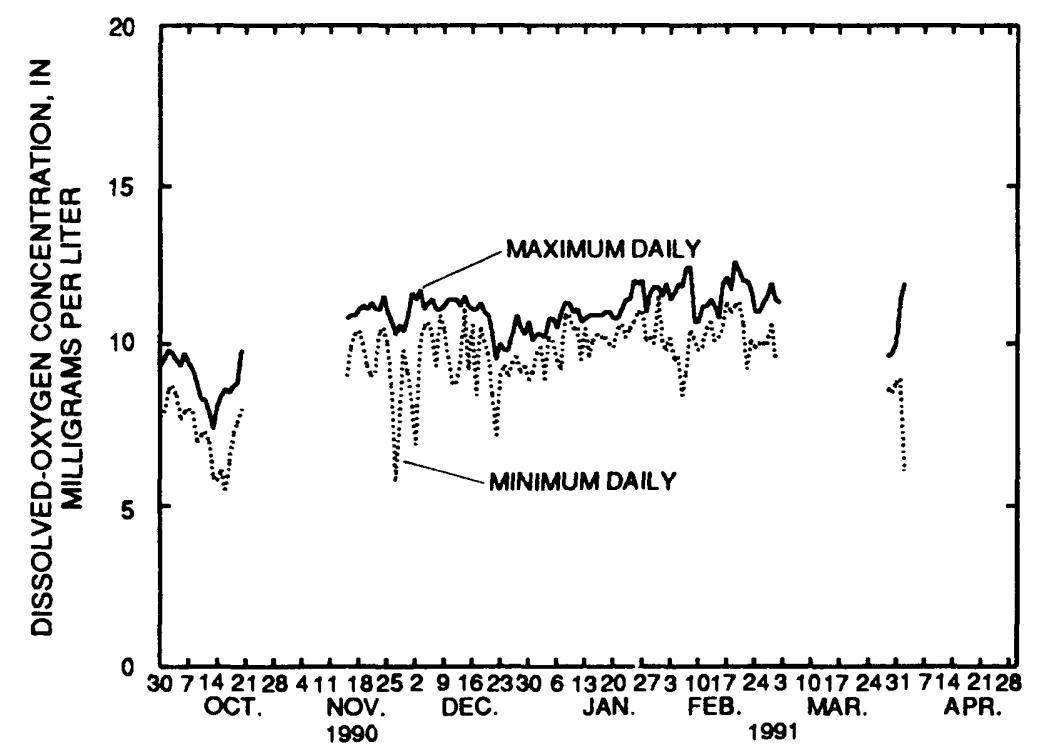


Table 63.--Daily mean values of dissolved-oxygen concentration, near bottom, in water at site 5, Currituck Sound at U.S. Highway 158 bridge, January through September 1990

STATION NUMBER AND NAME: 0204295500, Currituck Sound at U.S. Highway 158 bridge LATITUDE: $36^{\circ} 05^{\prime} 12^{\prime \prime}$ LONGITUDE: $75^{\circ} 46^{\prime} 06^{\prime \prime}$ COUNTY: Currituck PROBE LOCATION: 2 feet above bottom

[Dissolved-oxygen concentration, milligrams per liter; ---, no data]

\begin{tabular}{|c|c|c|c|c|c|c|c|c|c|}
\hline Day & Jan. & Feb. & Mar. & Apr. & May & June & July & Aug. & Sept. \\
\hline 1 & --- & 11.0 & --- & 10.7 & 8.3 & 10.7 & 6.9 & 7.7 & 7.6 \\
\hline 2 & --- & 10.9 & 10.7 & 10.6 & 8.5 & -.. & 7.0 & 6.5 & 7.8 \\
\hline 3 & --- & 10.6 & 10.9 & 10.3 & 8.5 & --. & 6.8 & 5.2 & 7.8 \\
\hline 4 & -- & 10.3 & 10.9 & 10.2 & 8.7 & --- & 7.8 & 4.6 & 8.2 \\
\hline 5 & --- & --. & 10.6 & 10.5 & 8.8 & $\cdots$ & 7.3 & 7.6 & $\cdots$ \\
\hline 6 & --- & 10.4 & 10.5 & 10.4 & 8.7 & --- & 7.0 & 7.8 & 8.4 \\
\hline 7 & --- & 10.7 & 11.0 & 10.0 & 9.0 & --- & 7.1 & 6.9 & 8.3 \\
\hline 8 & -- & 10.7 & 11.0 & 10.2 & 9.3 & --- & 7.4 & 4.5 & -- \\
\hline 9 & -- & 11.1 & 11.2 & 10.4 & 9.1 & --- & 7.7 & 5.3 & 7.4 \\
\hline 10 & --- & 10.1 & 11.0 & 10.5 & 8.8 & --- & --- & 6.4 & 7.8 \\
\hline 11 & $\ldots$ & --- & 11.0 & 9.8 & 8.9 & -.. & --- & 7.4 & 7.6 \\
\hline 12 & --- & 10.3 & 10.8 & 9.8 & 9.2 & --- & 7.3 & 7.2 & 7.8 \\
\hline 13 & 12.7 & 10.4 & 10.5 & 10.2 & 9.0 & --. & 7.0 & 7.1 & 7.5 \\
\hline 14 & 12.6 & 10.5 & 9.6 & 10.4 & 8.8 & --- & 7.2 & 6.7 & 7.4 \\
\hline 15 & 12.5 & 10.5 & 10.2 & 9.3 & 8.5 & --- & 7.0 & 6.1 & 8.0 \\
\hline 16 & 12.1 & 10.0 & 9.4 & 9.7 & 8.7 & ... & --- & 6.4 & 7.2 \\
\hline 17 & 11.9 & 9.6 & 9.1 & 10.0 & 8.4 & --- & 6.0 & 6.1 & 8.4 \\
\hline 18 & 12.3 & 10.0 & 8.8 & 10.0 & 8.2 & --- & 6.5 & 6.2 & 8.4 \\
\hline 19 & 12.0 & 10.0 & 8.9 & 10.2 & 8.1 & --- & 6.3 & 6.7 & 8.6 \\
\hline 20 & 11.5 & 10.4 & 9.2 & 10.2 & -- & --- & 7.5 & 6.9 & 8.6 \\
\hline 21 & 11.6 & 10.7 & 10.1 & 10.2 & --- & $\cdots$ & 7.5 & 6.7 & 8.0 \\
\hline 22 & 11.3 & 10.8 & 10.3 & 9.8 & 7.8 & 4.2 & 7.4 & 7.0 & 8.6 \\
\hline 23 & 11.2 & --- & 10.1 & 9.8 & 8.3 & 6.3 & 7.2 & 6.9 & 8.4 \\
\hline 24 & 11.3 & 10.0 & 10.2 & 8.9 & 8.7 & 6.4 & 7.5 & 7.0 & 8.6 \\
\hline 25 & 11.6 & --- & 10.1 & 8.8 & 9.3 & 6.5 & 7.5 & 6.6 & 8.8 \\
\hline 26 & 10.8 & 11.8 & 10.3 & 8.6 & 13.7 & 6.2 & 7.6 & 7.0 & 8.9 \\
\hline 27 & 10.7 & 11.5 & 10.5 & 8.2 & 10.0 & 6.0 & 6.8 & 6.6 & 9.1 \\
\hline 28 & 11.1 & 11.9 & 10.8 & 8.4 & 8.9 & 6.5 & 7.1 & 7.6 & 8.5 \\
\hline 29 & 11.3 & $\cdots$ & 10.8 & 8.2 & 9.0 & 7.2 & 7.5 & 7.6 & 8.1 \\
\hline 30 & 10.9 & --- & 10.6 & 8.1 & 9.5 & 6.8 & 7.5 & 7.4 & 8.2 \\
\hline 31 & 11.2 & $\cdots$ & 10.4 & $\cdots$ & 9.7 & -- & 7.7 & 7.2 & $\cdots$ \\
\hline
\end{tabular}

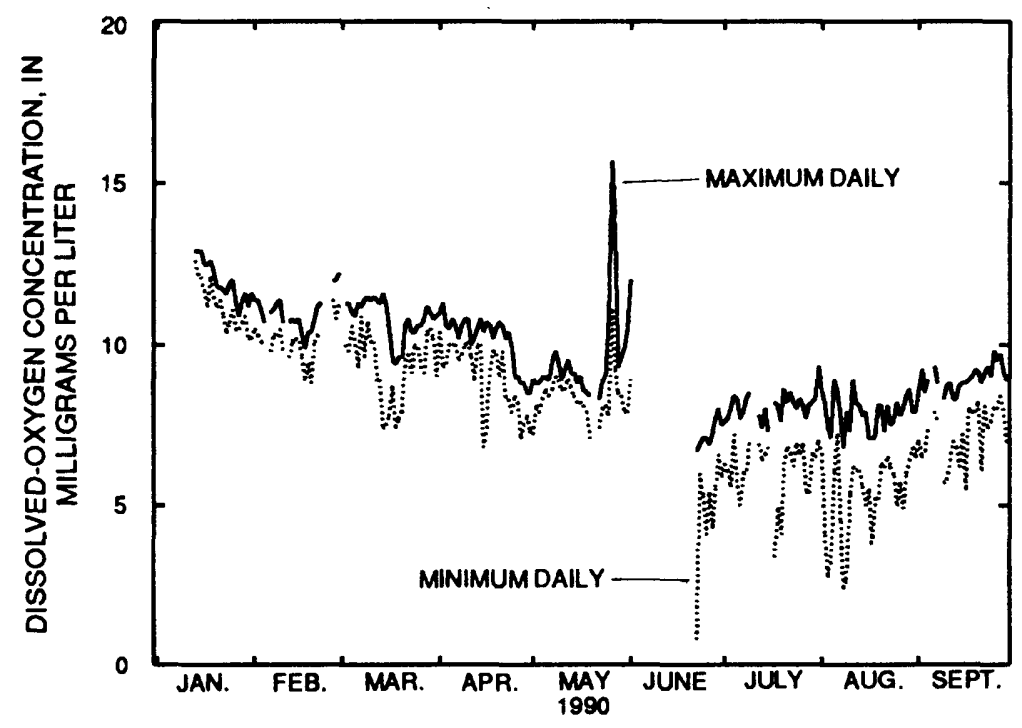


Table 64.--Daily mean values of dissolved-oxygen concentration, near bottom, in water at site 5, Currituck Sound at U.S. Highway 158 bridge, October 1990 through April 1991

STATION NUMBER AND NAME: 0204295500, Currituck Sound at U.S. Highway 158 bridge LATITUDE: $36^{\circ} 05^{\prime} 12^{\prime \prime}$ LONGITUDE: $75^{\circ} 46^{\circ} 06^{\prime \prime}$ COUNTY: Currituck PROBE LOCATION: 2 feet above bottom

[Dissolved-oxygen concentration, milligrams per liter; --., no data]

\begin{tabular}{|c|c|c|c|c|c|c|c|}
\hline Day & Oct. & Nov. & Dec. & Jan. & Feb. & Mar. & Apr. \\
\hline 1 & 8.7 & 9.7 & 9.7 & 11.0 & 11.5 & --- & 10.2 \\
\hline 2 & 8.9 & 9.1 & 9.6 & 11.2 & 11.4 & --- & 10.7 \\
\hline 3 & 8.7 & 8.2 & 10.5 & 10.8 & 11.4 & $\cdots$ & -- \\
\hline 4 & 9.2 & 7.8 & 10.4 & 11.4 & 11.3 & --- & --- \\
\hline 5 & 8.7 & 6.9 & 10.7 & 11.4 & 11.2 & -- & --- \\
\hline 6 & 8.6 & 9.4 & 10.7 & 11.2 & 10.5 & -- & -- \\
\hline 7 & 8.8 & 9.1 & 10.5 & 11.5 & 11.0 & -- & -- \\
\hline 8 & 8.4 & 9.7 & 11.2 & 11.5 & 11.3 & --- & --- \\
\hline 9 & 8.2 & 9.3 & 11.0 & 11.4 & 10.6 & --- & --- \\
\hline 10 & 8.1 & 9.8 & 11.0 & 11.2 & 10.6 & --- & --- \\
\hline 11 & 8.2 & 9.9 & 11.1 & 11.2 & 10.9 & -- & -- \\
\hline 12 & 7.6 & 9.8 & 10.6 & 10.8 & 11.1 & --- & --- \\
\hline 13 & 6.7 & 10.4 & 10.6 & 10.9 & 11.2 & --- & -- \\
\hline 14 & 7.4 & --- & 11.3 & 10.9 & 10.8 & --- & --- \\
\hline 15 & 7.9 & 10.3 & 10.7 & 11.1 & 10.7 & --- & -- \\
\hline 16 & 8.3 & 10.2 & 10.8 & 11.1 & --- & --- & -- \\
\hline 17 & 8.1 & 10.5 & 10.7 & 11.0 & --- & -- & $\cdots$ \\
\hline 18 & 8.4 & 10.7 & 10.9 & 11.0 & -- & -- & --- \\
\hline 19 & 8.7 & 10.6 & 10.6 & 10.9 & -.- & --- & -- \\
\hline 20 & 8.8 & 10.3 & 10.6 & 10.9 & -- & --- & -- \\
\hline 21 & 8.1 & 10.4 & 10.1 & 10.9 & --- & --- & -- \\
\hline 22 & 8.3 & 10.2 & 9.9 & 11.0 & -- & --- & -- \\
\hline 23 & 8.6 & 10.4 & 10.6 & 11.2 & $\cdots$ & -- & -.- \\
\hline 24 & 8.0 & 10.5 & 10.3 & 11.5 & $\cdots$ & $\cdots$ & -- \\
\hline 25 & 8.5 & 10.4 & 10.3 & 11.7 & -- & --- & -- \\
\hline 26 & 9.4 & 10.1 & 10.8 & 11.7 & -- & -- & $\cdots$ \\
\hline 27 & 10.1 & 9.2 & 11.4 & 11.8 & $\cdots$ & -- & $\cdots$ \\
\hline 28 & 10.1 & 9.7 & 11.1 & 11.4 & --. & 9.6 & -- \\
\hline 29 & 10.4 & 10.1 & 11.2 & 11.7 & -- & 9.4 & --- \\
\hline 30 & 10.4 & 10.4 & 11.3 & 11.6 & -- & 9.3 & $\cdots$ \\
\hline 31 & 10.2 & --- & 10.9 & 11.8 & $\ldots$ & 9.9 & -- \\
\hline
\end{tabular}

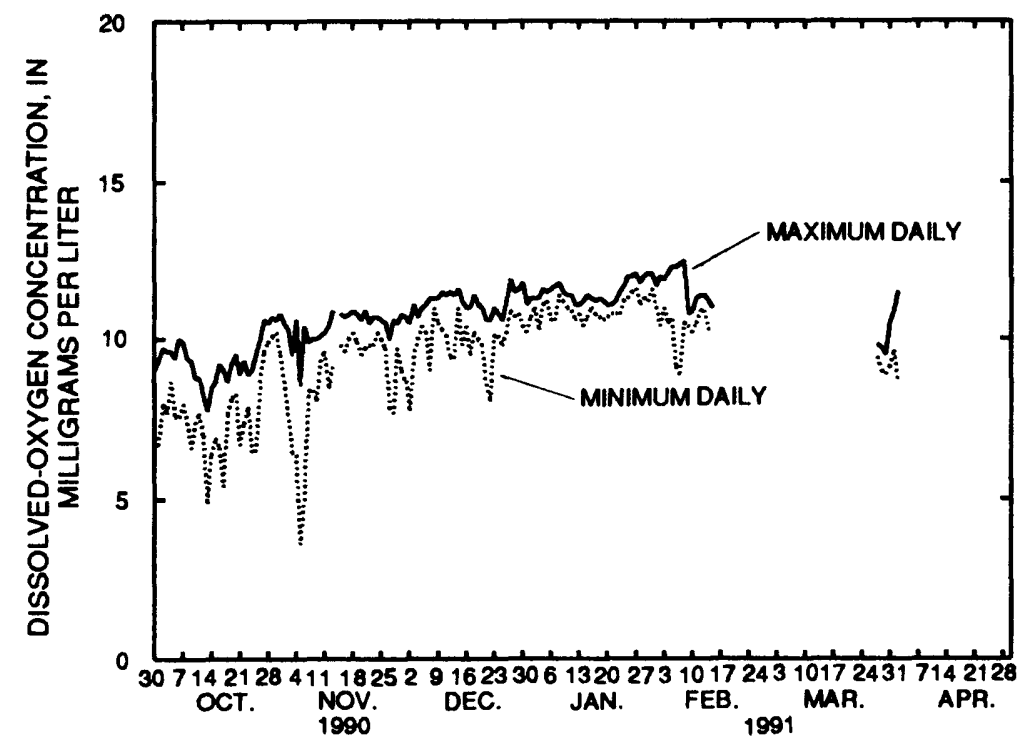


Multiply

inch (in.)

foot (ft)

mile (mi)

square mile $\left(\mathrm{mi}^{2}\right)$

gallon (gal)

cubic foot per second $\left(\mathrm{ft}^{3} / \mathrm{s}\right)$

cubic foot per second per

square mile $\left.\left[\left(\mathrm{ft}^{3} / \mathrm{s}\right) / \mathrm{mi}^{2}\right)\right]$

pound, avoirdupois (lb)
By

To obtain

\section{Length}

\section{4}

0.3048

1.609

\section{Area}

2.590

\section{Volume}

3.785

liter

\section{Flow}

0.02832

0.0109

Mass

0.4536 millimeter

meter

kilometer square kilometer

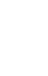

